\author{
UNIVERSIDADE DE SÃO PAULO - USP \\ FACULDADE DE MEDICINA DE RIBEIRÃO PRETO - FMRP \\ FUNDAÇÃO HEMOCENTRO DE RIBEIRÃO PRETO - FUNDHERP
}

Papel da sinalização da adenosina na geração de células $T$ regulatórias a partir de células $T$ naive de cordão umbilical e na imunomodulação por células-tronco estromais mesenquimais de medula óssea

Helder Teixeira De Freitas

RIBEIRÃO PRETO 


\section{UNIVERSIDADE DE SÃO PAULO - USP \\ FACULDADE DE MEDICINA DE RIBEIRÃO PRETO - FMRP \\ FUNDAÇÃO HEMOCENTRO DE RIBEIRÃO PRETO - FUNDHERP}

Helder Teixeira De Freitas

Papel da sinalização da adenosina na geração de células $\mathrm{T}$ regulatórias a partir de células $\mathrm{T}$ naive de cordão umbilical e na imunomodulação por células-tronco estromais mesenquimais de medula óssea

Tese apresentada ao Programa de Pós-Graduação em Oncologia Clínica, Células-Tronco e Terapia Celular da Faculdade de Medicina de Ribeirão Preto da Universidade de São Paulo, como parte dos pré-requisitos para obtenção do título de Doutor em Ciências.

Área de concentração: Células-tronco e Terapia Celular

Orientador: Prof. Dr. Rodrigo Alexandre Panepucci 
Autorizo a reprodução e divulgação total ou parcial deste trabalho, por qualquer meio convencional ou eletrônico, para fins de estudo ou de pesquisa, desde que citada a fonte.

\section{FICHA CATALOGRÁFICA}

\section{DeFreitas, Helder Teixeira}

Papel da sinalização da adenosina na geração de células $T$ regulatórias a partir de células $T$ naive de cordão umbilical e na imunomodulação por células-tronco estromais mesenquimais de medula óssea

Ribeirão Preto, 2018.

Tese de Doutorado, apresentada à Faculdade de Medicina de Ribeirão Preto/USP. Área de Concentração: Células-tronco e terapia celular.

Orientador: Panepucci, Rodrigo Alexandre Panepucci. 


\section{FOLHA DE APROVAÇÃO}

Papel da sinalização da adenosina na geração de células T regulatórias a partir de células T naive de cordão umbilical e na imunomodulação por células-tronco estromais mesenquimais de medula óssea

Tese apresentada ao Programa de Pós-Graduação em Oncologia Clínica, Células-Tronco e Terapia Celular da Faculdade de Medicina de Ribeirão Preto da Universidade de São Paulo, como parte dos pré-requisitos para obtenção do título de Doutor em Ciências.

Área de concentração: Células-tronco e Terapia Celular

Banca Examinadora:

Prof. Dr.

Instituição

Assinatura:

Prof. Dr.

Instituição

Assinatura:

Prof. Dr.

Instituição

Assinatura:

Prof. Dr.

Instituição

Assinatura:

Prof. Dr.

Instituição

Assinatura: 
Dedico esse trabalho aos meus pais, que sempre me fizeram acreditar na educação. 


\section{AGRADECIMENTOS}

Ao orientador Prof Dr Rodrigo Alexandre Panepucci, a palavra que expressa minha admiração e respeito é gratidão. Obrigado pela oportunidade de desenvolver esse trabalho, pela confiança, pelas discussões e todos os ensinamentos ao longo desses anos.

Á MATER de Ribeirão Preto, à enfermeira Maria Fernanda Lopes, que realizou as coletas de sangue, e a todas as mães que doaram o sangue de cordão umbilical de seus filhos, obrigado ainda aos colaboradores do Hemocentro da Criobiologia, aos colaboradores da Hematologia II, e principalmente a Camila Bonaldo, pela ajuda com as aquisições dos dados de citometria de fluxo, assim como todos que ajudaram para que essa pesquisa pudesse ser realizada

A Fundação Hemocentro de Ribeirão, pela oportunidade da realização do Doutorado e a funcionários e colegas da pós-graduação. Nele foram realizados grande parte dos experimentos deste trabalho. Ao professor Dr Vitor Faça pela colaboração com as análises de espectometria de massas.

À banca examinadora pela disposição em participar na contribuição para o crescimento deste trabalho.

À Fundação de Amparo à Pesquisa do Estado de São Paulo (FAPESP) por ter concedido a bolsa regular de Doutorado (processo FAPESP 2014/02574-7).

As técnicas do laboratório Amélia Goes de Araújo, Marli Haydee Tavella, Elizabete Tavares Figueiredo Auddino, Júlia Mieko Yoshida Komoto, Cláudia Helena Avelar e Priscila Scheucher.

Aos amigos do laboratório Josiane Schiavinato, Mariane Fráguas, Bruno Sangiorgi, Ildercílio Lima, Danuta Sastre, Sarah Blima, Vitor Leão, Igor Lopes, Hudson Bezerra, Felipe Canto e Amanda Corveloni. A nossa convivência sempre foi baseada no respeito, na união, no companheirismo e na solidariedade. Obrigado por tudo.

A secretária da pós graduação, Adriana Fuzaro, por todo auxílio durante o doutorado e as reuniões da CCP. Obrigado pela sua dedicação e postura sempre otimista.

A minha família, minha base, meu porto seguro. Em especial aos meus pais Rosa e Joaquim, irmãos Laura e Natanael e sobrinhos Crisnael e Naiane, pela compreensão, apoio e respeito a minha ausência. Obrigado por não medirem esforços para me fazerem feliz, pelo incentivo, pela confiança e amor incondicional. 
Ao Bruno, agradeço por existir alguém como você em minha vida, exemplo de simplicidade, companheirismo e amor. Obrigado por dividir comigo todos os momentos.

Às minhas tias Angela, Graça, Tereza e Dalva por sempre terem feito o papel de segundas mães. Obrigado por serem exemplos de ternura em minha vida.

As amigas doutoras Fernanda, Lais e Nathalia, a vocês meu eterno agradecimento por poder compartilhar todos os momentos, por serem a minha família de Ribeirão Preto. Obrigado por tornarem tudo mais simples, pelas risadas, pelo carinho e amizade.

Aos meus amigos, familiares e a todos que de alguma forma, me auxiliaram, incentivaram ou proporcionaram bons momentos para a continuação e finalização deste trabalho.

A Deus, que me iluminou e me deu forças durante toda a trajetória. 
"Litterarum radices amarae, fructus dulces."

Cicero 


\section{LISTA DE ABREVIATURAS}

APC: Célula Apresentadora de Antígeno (do inglês: "Antigen Presenting Cell")

atRA: Ácido Trans-Retinóico (do inglês: "all trans retinoic acid")

CD127: receptor de IL-7

CD25: receptor alpha do IL-2

CFSE: 5,6-carboxy fluorescein diacetate succinimidyl Ester

CTLA4: antígeno 4 associado ao linfócito $T$ citotóxico (do inglês: cytotoxic $T$ Lymphocyte-associated protein 4)

FOXP3: fator de transcrição Foxp3 (do inglês: forkhead transcription factor Box $P 3)$

GITR: fator de necrose tumoral induzido por glicocorticoide (do inglês: glucocorticoid-induced TNF receptor-related protein)

IL-2: interlecina 2

IL-6: interleucina 6

IL-17: interleucina 17

iTreg: Treg induzida

PBS: "Phosphate Buffered Saline"

SCU: sangue de cordão umbilical

TCR: Receptor de Células T (do inglês: "T Cell Receptor")

TGF- $\beta$ : do inglês: "Transforming Growth Factor beta"

Th17: Célula efetora produtora de IL-17 (do inglês "IL-17-producing effector T helper cells")

Treg: $\mathrm{CD} 4^{+} \mathrm{CD} 25^{-}$regulatory $\mathrm{T}$ cell 


\section{SUMÁRIO}

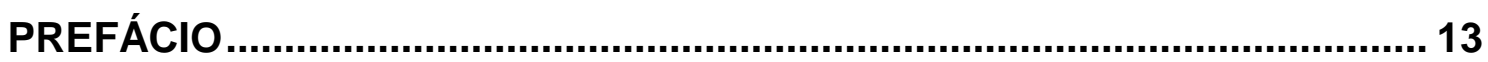

CAPITULO I: GERAÇÃO DE CÉLULAS T REGULATÓRIAS A PARTIR DE CÉLULAS T NAIVE: PAPEL DA SINALIZAÇÃO DA ADENOSINA ................15

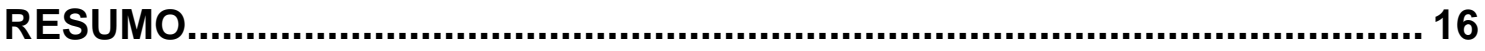

ABSTRACT

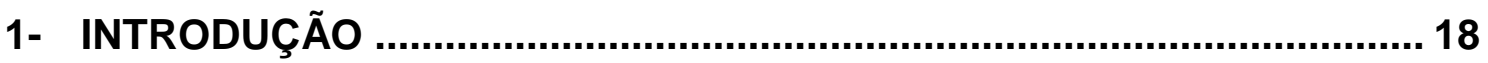

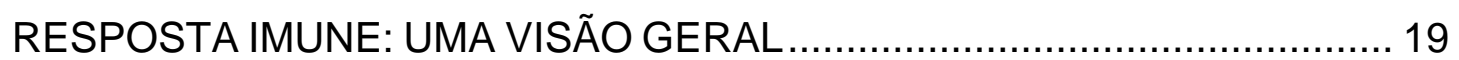

LINFÓCITOS T: DIVERSIDADE VERSUS TOLERÂNCIA ............................ 21

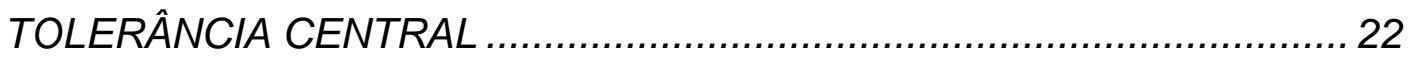

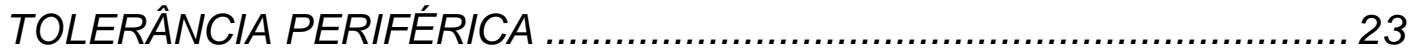

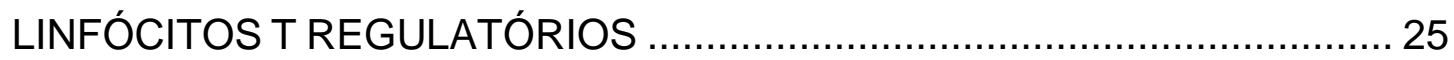

GERAÇÃO DE LINFÓCITOS TREG IN VITRO …....................................... 27

PAPEL DA ADENOSINA NO CONTROLE DA RESPOSTA IMUNE NOS

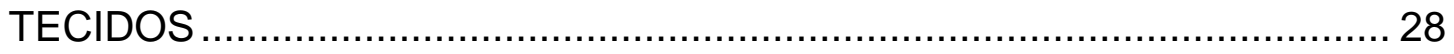

MECANISMOS IMUNOMODULATÓRIOS DA ADENOSINA ….................... 30

EXPRESSÃO DE CD39 E CD73 E PRODUÇÃO DE ADENOSINA PELAS

TREGS.................................................................................... 31

PAPEL DA ADENOSINA E SEUS RECEPTORES NA DIFERENCIAÇÃO DE

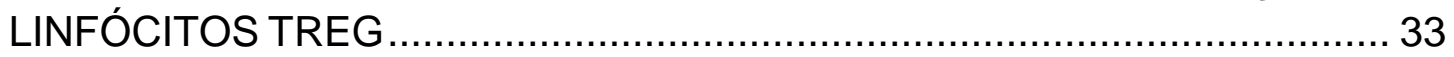

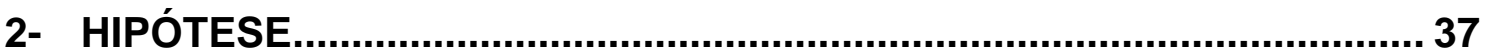

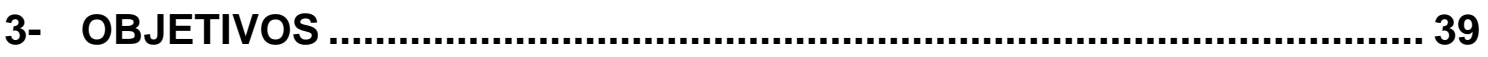

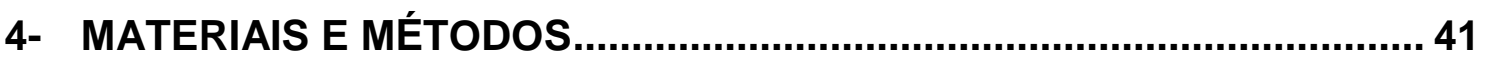

ESPECIFICIDADE DOS AGONISTAS E ANTAGONISTAS UTILIZADOS .... 42

COLETA DO SANGUE DE CORDÃO UMBILICAL......................................46

OBTENÇÃO DE CÉLULAS NAIVE DE CORDÃO UMBILICAL .......................46

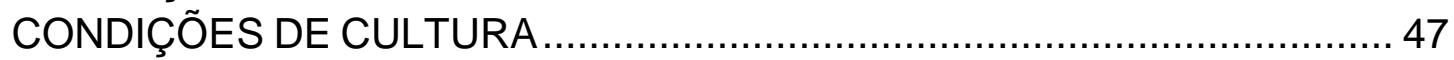

IMUNOFENOTIPAGEM POR CITOMETRIA DE FLUXO ............................. 48

ISOLAMENTO DAS LINFÓCITOS T CD3+ EFETORES E TREGS

CD4+CD25HI E CD4+CD25+CD127- ............................................ 49

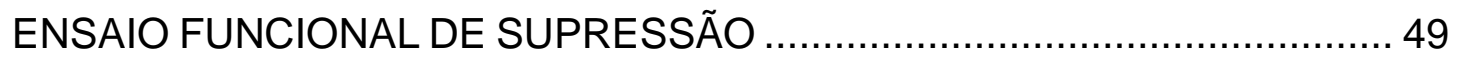

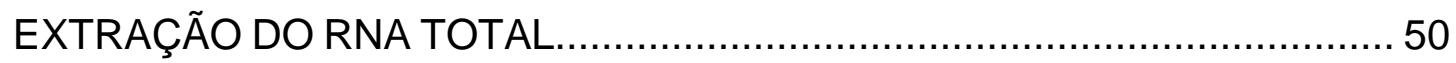

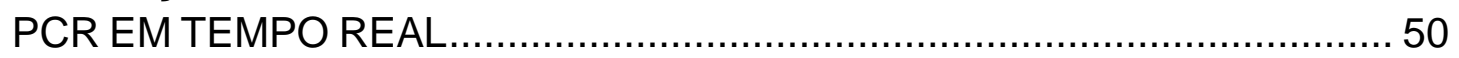

QUANTIFICAÇÃO DE CITOCINAS.......................................................... 51

QUANTIFICAÇÃO DE ADENOSINA PRODUZIDA PELOS LINFÓCITOS NAS

DIFERENTES CONDIÇÕES DE MODULAÇÃO FARMACOLÓGICA DOS

RECEPTORES DE ADENOSINA.............................................................. 51

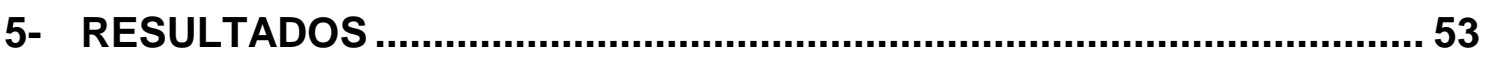


OBTENÇÃO DOS LINFÓCITOS T NAIVE DE SANGUE DE CORDÃO UMBILICAL

EXPRESSÃO GÊNICA DE ADA, CD39, CD73 E RECEPTORES DE ADENOSINA EM LINFÓCITOS T.

EFEITO DA MODULAÇÃO FARMACOLÓGICA DOS RECEPTORES DE ADENOSINA NA GERAÇÃO DE ITREGS EXPRESSANDO CD39 E CD73 DE SUPERFÍCIE 57

AVALIAÇÃO INICIAL: PAPEL DOS RECEPTORES A2A E A2B NA GERAÇÃO DE ITREGS EXPRESSANDO CD39 E CD73 DE SUPERFÍCIE . 58 PAPEL DOS DIFERENTES RECEPTORES DE ADENOSINA NA GERAÇÃO DE ITREGS EXPRESSANDO CD39 E CD73 DE SUPERFÍCIE PAPEL DO RECEPTOR A1 DE ADENOSINA NO PERFIL DE CITOCINAS . 66 PRODUÇÃO DE ADENOSINA NAS CONDIÇÕES DE AGONISMO OU ANTAGONISMO DO RECEPTOR A1 DE ADENOSINA

6- DISCUSSÃO 69

ESTUDO DA SINALIZAÇÃO DA ADENOSINA E SEUS RECEPTORES PELO USO DE AGONISTAS E ANTAGONISTAS FARMACOLÓGICOS ........ ERROR! BOOKMARK NOT DEFINED.

INDUÇÃO DE TREGS EXPRESSANDO CD39 E CD73 DE SUPERFÍCIE ERROR! BOOKMARK NOT DEFINED.

7- CONCLUSÕES 85

CAPITULO II: CD39 EM CÉLULAS-TRONCO ESTROMAIS MESENQUIMAIS E LINFÓCITOS T CD3+ ATIVADOS 87

RESUMO 88

ABSTRACT

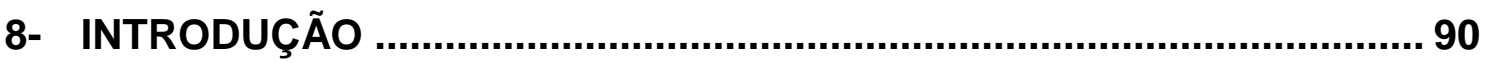

8.1 CÉLULAS-TRONCO ESTROMAIS MESENQUIMAIS ............................ 93

8.2 MECANISMOS DE IMUNOMODULAÇÃO MEDIADA POR CÉLULAS

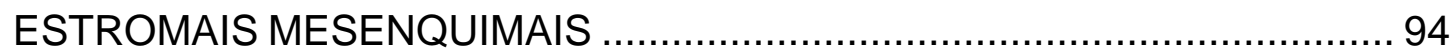

8.3 CD39 E CD73 EM CÉLULAS ESTROMAIS MESENQUIMAIS................ 95

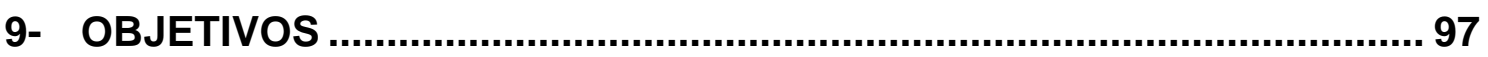

10- HIPÓTESE

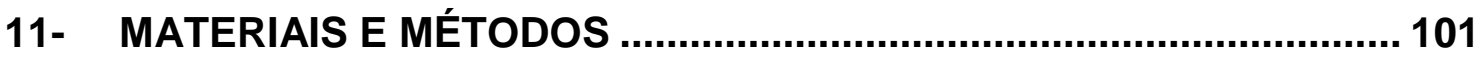

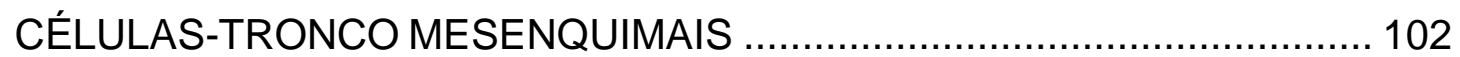

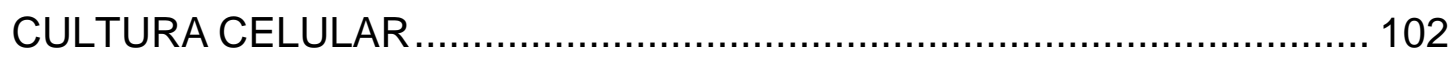

OBTENÇÃO DAS CÉLULAS MONONUCLEARES DO SANGUE

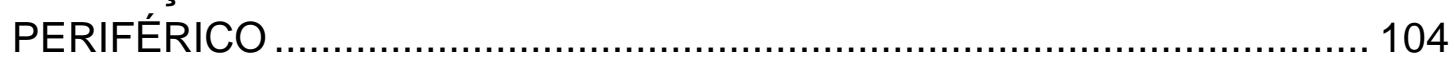

SEPARAÇÃO IMUNOMAGNÉTICA DOS LINFÓCITOS T .......................... 104

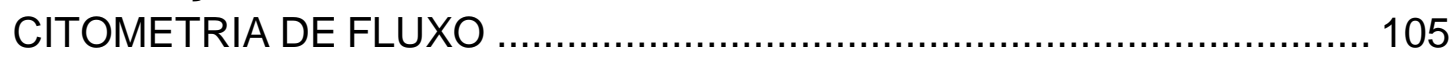




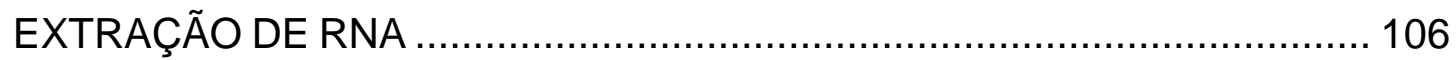

ANÁLISE DE EXPRESSÃO GÊNICA ...................................................... 106

MICROSCOPIA DE FLUORESCÊNCIA QUANTITATIVA.......................... 107

ANÁLISE DAS IMAGENS DE MICROSCOPIA QUANTITATIVA - HIGH

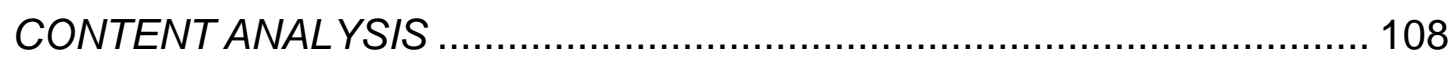

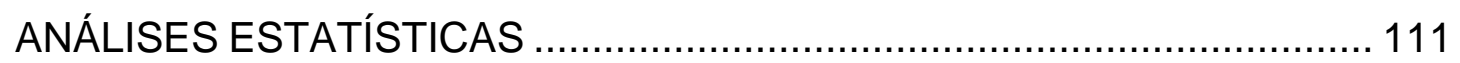

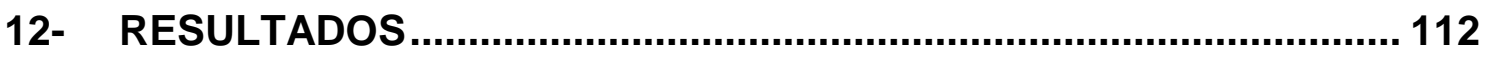

EXPRESSÃO GÊNICA DE ADA, CD39, CD73 E RECEPTORES DE

ADENOSINA EM CTMS .................................................................. 113

EFEITO DOS ESTÍMULOS INFLAMATÓRIOS NA EXPRESSÃO GENICA DE

ADA, CD39, CD73 E RECEPTORES DE ADENOSINA EM CTMS..............113

EFEITO DOS ESTÍMULOS INFLAMATÓRIOS NA EXPRESSÃO PROTEICA

E LOCALIZAÇÃO CELULAR DE CD39 E CD73 EM CTMS........................ 116

DIRECIONAMENTO DE CD39 E CD73 NAS CTMS, PARA A REGIÃO DE

INTERAÇÃO COM LINFÓCITOS T ATIVADOS ...................................... 119

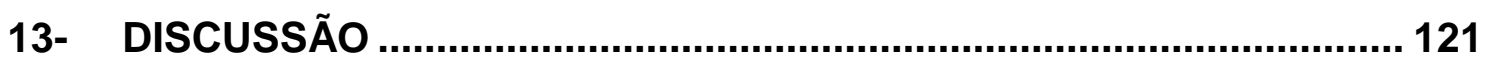

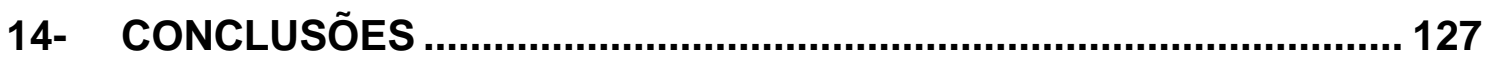

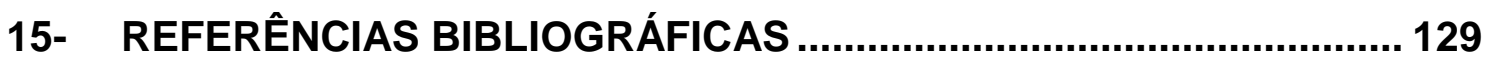

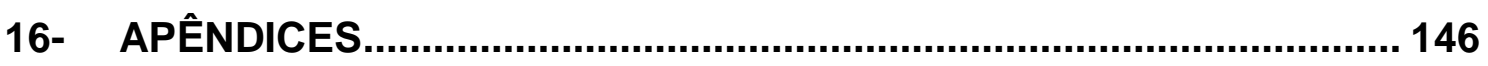

EFEITOS TÓXICOS E INESPECÍFICOS DO DMSO..................................... 147 PAPEL DOS RECEPTORES DE ADENOSINA NA EXPRESSÃO DE CD39 E CD73 DURANTE A INDUÇÃO DE LINFÓCITOS TREG RECEPTOR A1 ... 149 PAPEL DOS RECEPTORES DE ADENOSINA NO PERFIL DE CITOCINAS

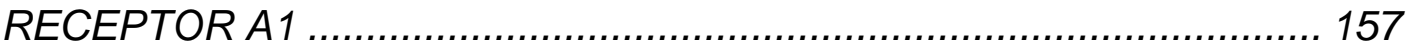

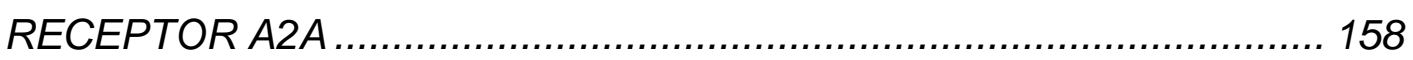

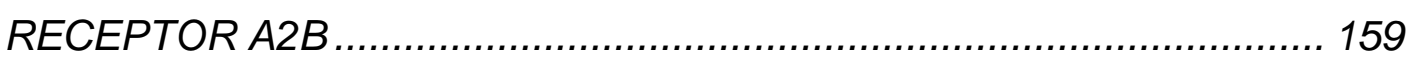

RECEPTOR A3 ……............................................................ 160

PRODUÇÃO DE ADENOSINA PELOS LINFÓCITOS NAS DIFERENTES

CONDIÇÕES DE MODULAÇÃO FARMACOLÓGICA DOS RECEPTORES DE

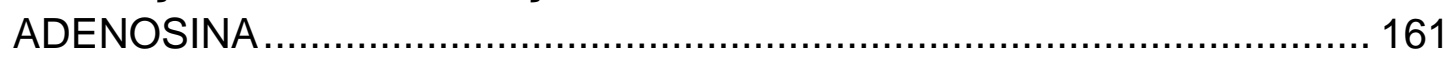

EFEITO DA MODULAÇÃO FARMACOLÓGICA DOS RECEPTORES DE ADENOSINA NA EXPRESSÃO GÊNICA DE ADA, CD39, CD73 E RECEPTORES DE ADENOSINA EM CTMS .......................................... 163 EFEITO DA MODULAÇÃO FARMACOLÓGICA DOS RECEPTORES DE ADENOSINA NA EXPRESSÃO PROTEICA E LOCALIZAÇÃO CELULAR DE

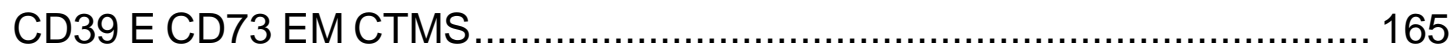

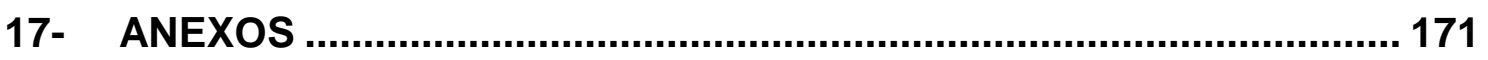

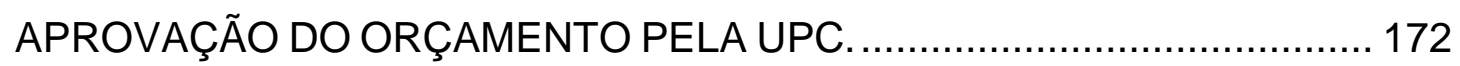

TERMO DE CONSENTIMENTO LIVRE E ESCLARECIDO. .......................173 
APROVAÇÃO NO COMITÊ DE ÉTICA DA MATER.

176

APROVAÇÃO NO COMITÊ DE ÉTICA DA FUNDHERP 
Com base no importante papel das células $T$ regulatórias na manutenção da tolerância periférica e prevenção de doenças autoimunes, este trabalho buscou investigar o processo de geração destas células, a partir de células $T$ naive isoladas de sangue de cordão umbilical, estimulando ou inibindo os diferentes receptores e sinalizadores da via de adenosina (ADO). Com base em um trabalho prévio do nosso grupo, que descreveu um novo mecanismo em que as CTMs suprimem a geração dos linfócitos $T$ ativados pelo aumento da expressão de CD39 e por diversos estudos que demonstram que a produção de ADO auxilia as Tregs na supressão celular, buscamos o estabelecimento de novos protocolos de geração de Tregs, com o auxílio de novas drogas relacionadas aos receptores de ADO.

Paralelamente, a investigação do efeito das drogas agonistas e antagonistas aos receptores de ADO durante a geração in vitro de células Tregs, buscamos investigar o envolvimento das ectonucleotidases e a sua potencial localização nas células tronco mesenquimais (CTM). Para isso, foram realizadas avaliações por GPCR, citometria de fluxo e microscopia multiparamétrica, explorando o efeito modulador in vitro das CTM isoladas ou em coculturas com linfócitos T $\mathrm{CD} 3^{+}$humanos ativados. As coculturas de CTMs e linfócitos T CD3 ${ }^{+}$ apresentaram aumento significativo na expressão de CD39 e CD73 em regiões de contato. Além disso, a incubação de CTMs com sobrenadante de meios de cultura condicionados por linfócitos $T$ ativados induziu uma expressão elevada de ADORA2A e produção de adenosina, indicando que a produção de adenosina era principalmente derivada de CTMs. Detectamos, ainda, significativa expressão citosólica de CD39 em CTM por permeabilização. Assim, nossos resultados indicam que o aumento da expressão de CD39/CD73 durante a interação de $\mathrm{CTM}$ e linfócitos $\mathrm{T} \mathrm{CD3}^{+}$pode estar relacionado às propriedades imunomoduladoras das CTMs. Estes dados podem abrir novas alternativas para o estudo da imunomodulação mediada por CTM e sua aplicação no desenvolvimento de novos tratamentos para GVHD e outras doenças inflamatórias 


\title{
CAPITULO I:
}

GERAÇÃO DE CÉLULAS T REGULATÓRIAS

A PARTIR DE CÉLULAS T NAIVE: PAPEL DA

\author{
SINALIZAÇÃO DA ADENOSINA
}




\section{RESUMO}

Geração de células t regulatórias a partir de células t naive: papel da sinalização da adenosina

As células $T$ regulatórias (Tregs) são essenciais para a manutenção da tolerância periférica, prevenção de doenças autoimunes e limitantes nas doenças inflamatórias crônicas. Além disso, essas células exercem um papel fundamental no controle da rejeição de transplantes. Diferentes protocolos mostraram que é possível obter Tregs a partir de células $\mathrm{T}$ naive $\mathrm{CD}^{+}{ }^{+}$in vitro. Para tal, é consenso que o TGF- $\beta$ e a interleucina-2 (IL-2) são capazes de direcionar as células $\mathrm{T}$ naive $\mathrm{CD}^{+}{ }^{+}$a se tornarem regulatórias após um estímulo antigênico (anti-CD3/CD28). Nosso grupo recentemente notou que, durante a imunomodulação de linfócitos $T$ pelas células estromais mesenquimais (CTMs), estas eram capazes de produzir adenosina que, por sua vez, participa do processo de imunorregulação. Outros trabalhos indicam que as CTMs suprimem a proliferação dos linfócitos $T$ pela geração de Tregs e que as CTMs induzem a geração de Tregs através da regulação negativa da via TCR e da via AKTmTOR. Evidências apontam que a adenosina pode atuar regulando negativamente a via mTOR. Portanto, acredita-se que a adenosina possa participar do processo de geração de Tregs através da modulação da via mTOR. Além disso, estudos recentes indicam que a ativação de receptores de adenosina, mais especificamente $\mathrm{A} 2 \mathrm{a}$, com agentes agonistas, leva ao aumento da produção de células Tregs, enquanto que a utilização de agentes antagonistas destes receptores leva à diminuição da diferenciação de Tregs. Porém, estes estudos mostram a geração de Tregs a partir de células $T$ naive de camundongos. Visto a grande importância das Tregs no contexto imunológico, a produção eficiente de Tregs in vitro tem importância fundamental para o desenvolvimento de novos protocolos terapêuticos para o tratamento de doenças autoimunes e no combate à rejeição de transplantes. Assim, o objetivo central deste trabalho foi avaliar a participação de agonistas e antagonistas de receptores de adenosina na indução de células T regulatórias geradas in vitro (iTreg) pela ativação de células T CD4 ${ }^{+}$naive isoladas de sangue de cordão umbilical (SCU) humano. Para isso, células mononucleares foram isoladas de bolsas de SCU e as células T naive foram isoladas imunomagnéticamente. Essas células foram ativadas com beads ligadas a anticorpos anti-CD2/CD3/CD28 e cultivadas por cinco dias na presença de IL-2 e diferentes concentrações de drogas agonistas e antagonistas de receptores de adenosina. Em seguida, foram avaliados os principais marcadores de células $T$ regulatorias por meio de citometria de fluxo e o meio de cultura foi coletado ao final da geração para quantificação de citocinas. Além disso, o RNA total foi extraído de todas as condições de cultivo para a análise da expressão de genes envolvidos na geração e desenvolvimento das Tregs, por PCR quantitativo. O potencial de supressão de células $T$ efetoras também foi avaliado.

Palavras-chave: T regulatórias; adenosina; CD39. 


\begin{abstract}
Generation of regulatory t cells from naive T cells: role of adenosine signaling
\end{abstract}

Regulatory T cells (Tregs) are essential for the maintenance of peripheral tolerance, prevention of autoimmune and limiting diseases in chronic inflammatory diseases. In addition, these cells play a key role in the control of transplant rejection. Different protocols have shown that it is possible to obtain Tregs from naive CD4+ T cells in vitro. To this end, there is consensus that TGF- $\beta$ and interleukin-2 (IL-2) are capable of directing the naive CD4 + T cells to become regulatory following an antigenic stimulus (anti-CD3/CD28).. Our group recently noted that during the immunomodulation of $T$ lymphocytes by mesenchymal stromal cells (MSCs), they were able to produce adenosine which in turn participates in the immunoregulation process. Other studies indicate that MSCs suppress the proliferation of $\mathrm{T}$ lymphocytes by generation of Tregs and that MSCs induce generation of Tregs by downregulation of the TCR pathway and the AKT-mTOR pathway. Evidence indicates that adenosine may act by downregulating the mTOR pathway. Therefore, it is believed that adenosine may participate in the generation of Tregs by modulating the mTOR pathway. In addition, recent studies indicate that activation of adenosine receptors, more specifically A2a, with agonist agents, leads to increased production of Treg cells, whereas the use of antagonistic agents of these receptors leads to a decrease in Treg differentiation.. However, these studies show the generation of Tregs from naive $T$ cells of mice. In view of the great importance of Tregs in the immunological context, the efficient production of Tregs in vitro is of fundamental importance for the development of new therapeutic protocols for the treatment of autoimmune diseases and in the fight against transplant rejection. Thus, the central objective of this study was to evaluate the participation of adenosine receptor agonists and antagonists in induction of regulatory T cells generated in vitro (iTreg) by the activation of naive CD4+ T cells isolated from human umbilical cord blood (SCU). For this, mononuclear cells were isolated from SCU and naive $\mathrm{T}$ cells were immunomagnetic isolated. These cells were activated with beads bound to anti-CD2/CD3/CD28 antibodies and cultured for five days in the presence of IL-2 and different concentrations of agonist drugs and antagonists of adenosine receptors. Next, the major regulatory T-cell markers were assessed by flow cytometry and the culture medium was collected at the end of the generation for quantification of cytokines. In addition, total RNA was extracted from all culture conditions for the analysis of the expression of genes involved in the generation and development of Tregs by quantitative PCR. The potential for suppression of effector T cells was also evaluated.

Keywords: Regulatory T cell; adenosine; CD39. 
1- INTRODUÇÃO 


\section{Resposta imune: uma visão geral}

No sistema imunológico de mamíferos, a imunidade inata e a adaptativa, desempenham papéis complementares. A imunidade inata é a primeira e mais rápida linha de defesa e envolve células como, macrófagos, mastócitos, neutrófilos, eosinófilos, células Natural Killer (NK) e células dendríticas (JANEWAY; MEDZHITOV, 2002; TURVEY; BROIDE, 2010). Por meio de um repertório com ampla especificidade, mas com um número limitado de receptores de padrões, as células imunes inatas são capazes de reconhecer padrões moleculares associados a sinais de perigo de danos teciduais ou de patógenos invasores (DAMPs e PAMPs, do inglês Danger- ou Pathogenassociated molecular pattern, respectivamente), iniciando uma resposta imune primária prontamente (KONO; ROCK, 2008).

Em contrapartida, os linfócitos $\mathrm{T}$ e $\mathrm{B}$ mediam a imunidade adaptativa celular e humoral, respectivamente. Enquanto a imunidade humoral é mediada por anticorpos secretados pelos linfócitos B (presentes no sangue ou secreções), atuando principalmente contra microrganismos extracelulares e suas toxinas; a imunidade celular é mediada por linfócitos $T$, participando nas respostas contra microrganismos intracelulares como vírus e algumas bactérias. Tendo em vista seu caráter adaptativo, esta resposta é mais lenta que a resposta inata; no entanto, a diversidade enorme de receptores destas células permite que elas reconheçam virtualmente qualquer antígeno estranho ao organismo (i.e. advindos de patógenos). $\mathrm{Na}$ interseção destas duas respostas está a apresentação de antígenos a linfócitos $T$ por células apresentadoras de antígenos (APCs), um processo essencial para o início de uma resposta imune adaptativa (CHAPLIN, 2010).

De maneira geral, os linfócitos $\mathrm{T}$ se dividem em $\mathrm{T}$-auxiliares (ou $\mathrm{T}$ helper) e T-citotóxicos, sendo diferenciados pela expressão das proteínas de membrana CD4 e CD8, respectivamente. Enquanto linfócitos T CD4 reconhecem (por meio de seus TCRs) peptídeos antigênicos apresentados por APCs no contexto de molécula do complexo principal de histocompatibilidade (MHC) de classe II; os linfócitos CD8 os reconhecem no contexto de moléculas de MHC de classe I. Enquanto as moléculas de MHC-I apresentam peptídeos 
de proteínas presentes em seu citoplasma (advindas, por exemplo, de vírus invasores) via reticulo endoplasmático, as de MHC-II apresentam antígenos presentes em seus lisossomos, oriundos de patógenos (e.g. bactérias e fungos) endocitados. Assim, esta distinção permite que células tomadas por vírus sejam mortas por linfócitos T-citotóxicos CD8+, enquanto que APCs (como macrófagos) podem ser auxiliadas por linfócitos T CD4+, na sua tarefa de digerir patógenos endocitados e apresenta-los (CHAPLIN, 2010).

Os linfócitos $T$ helper são gerados no timo e emergem como células $\mathrm{CD}^{+}$naive $\left(\mathrm{CD}^{+} \mathrm{CD} 25^{-} \mathrm{CD}^{+} 5 \mathrm{RA}^{+}\right.$) (ROMAGNANI et al., 2009) e mediante ativação, deixam de expressar CD45RA e passam a expressar CD45RO. O contexto da apresentação do antígeno determina o resultado da resposta dos linfócitos $T$ que se segue; com a presença de moléculas co-estimuladoras na APC, em combinação com citocinas secretadas no meio, facilitando e direcionando o tipo de resposta dos linfócitos T. De maneira geral, após ativação, as células T podem proliferar e originar células T efetoras (Th1, Th2 e Th17), que mediam a proteção contra patógenos, e células $T$ regulatórias (Tregs), que garantem a homeostase imune, controlando reações exacerbadas ou auto-imunes (Figura 1) (MAHIC et al., 2008; ROMAGNANI et al., 2009; ZHOU; CHONG; LITTMAN, 2009).

As células Th1 participam da resposta imune contra microrganismos intracelulares e são geradas em elevadas concentrações de IL-12 (interleucina 12), IL-18 e/ou IFN-y (Interferon gamma) (LEE et al., 2001). Os linfócitos Th2 contribuem com a resposta imune humoral e sua polarização ocorre na presença de altos níveis de IL-4 e na ausência de IL-12 (O'GARRA; MURPHY, 1994). Finalmente, linfócitos Th17 possuem ação pró-inflamatória, atuando na eliminação de infecções por fungos e bactérias, e são gerados na presença de IL-6 e TGF- $\beta$ (do inglês "Transforming growth factor beta") (HARRINGTON et al., 2005). As Tregs, por sua vez, são produzidas na presença de TGF- $\beta$ e IL-2 e atuam na homeostase do sistema imunológico (CHEN et al., 2003; FANTINI et al., 2004). Estudos dos fatores que conduzem a evolução de cada linhagem definiram fatores de transcrição essenciais para cada subtipo como; Fator de transcrição T-box (Tbet) para Th1, GATA3 para Th2, FOXP3 para Treg e Bcl-6 para Tfh (WEINMANN, 2014). 


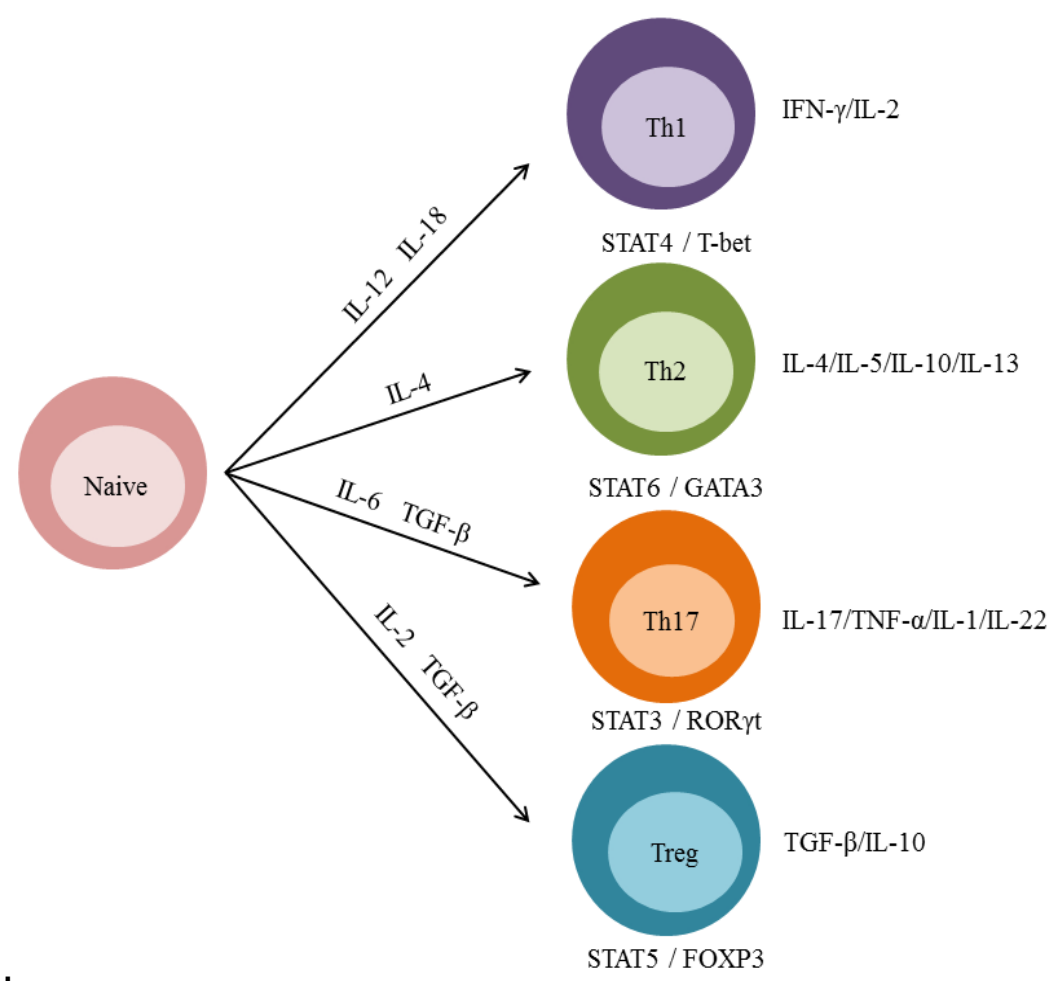

Figura 1. Processo de diferenciação das células T CD4 ${ }^{+}$naive. As células $T$ naive podem ser polarizadas em diferentes subtipos de células efetoras (Th1, Th2 e Th17) e em células T regulatórias (Tregs) de acordo com os estímulos a que são submetidas. A diferenciação de cada um dos subtipos é controlada pela expressão de diferentes fatores de transcrição. Adaptada de ZOU; RESTIFO (2010), Nature Reviews Immunology, 2010.

\section{Linfócitos T: Diversidade versus Tolerância}

A proteção contra um número virtualmente ilimitado de patógenos está relacionada à enorme diversidade de linfócitos $T$ com receptores de células $T$ (TCRs) funcionais capazes de reconhecer peptídeos antigênicos derivados destes patógenos. Esta diversidade resulta de um processo de "seleção positiva" que ocorre no timo (na região do córtex). Neste local, os precursores linfocíticos sofrem um processo de recombinação intra-cromossômica nos loci gênicos das cadeias que formam o TCR, resultando numa diversidade enorme de linfócitos T duplo-positivos (DP) CD4+CD8+, cada clone expressando um receptor específico (NEMAZEE, 2000). Estes precursores somente sobreviverão e se diferenciarão em células T CD4+ ou CD8+ simples positivas 
(SP), se reconhecerem peptídeos no contexto de molécula do complexo principal de histocompatibilidade $(\mathrm{MHC})$ de classe $I I$ e I, respectivamente, presentes num tipo especial de APCs chamadas células epiteliais tímicas corticais (cTECs). Linfócitos com arranjos de TCRs não funcionais, não recebem estes sinais de sobrevivência do TCR e sofrem a chamada "morte por negligência" (KLEIN et al., 2014). As cTECs possuem proteínas específicas, incluindo o timoproteassoma (contendo a subunidade catalítica específica do timo Psmb11//5t) e proteases lisossomais (catepsina L e Prss16/Tssp), que atuam na geração de um conjunto específico de autopeptídeos essenciais para a seleção positiva de células T CD8 e CD4, respectivamente (HOGQUIST; JAMESON, 2014).

Este processo origina um repertório aproximado entre $10^{9}$ a $10^{15}$ linfócitos T contendo TCRs com diferentes especificidades; o que teoricamente permitiria o reconhecimento de qualquer epítopo antigênico de qualquer proteína. Assim, inevitavelmente, este processo gera células que reconhecem auto-antígenos, de forma que a distinção entre antígenos externos (nãopróprios) e próprios se torna essencial para evitar a auto-imunidade e garantir a proteção dos tecidos próprios. Esta distinção é assegurada por dois mecanismos de auto-tolerância distintos: a tolerância central e a tolerância periférica (HOGQUIST; JAMESON, 2014; KLEIN et al., 2014; TAKABA; TAKAYANAGI, 2017).

\section{Tolerância Central}

Para os linfócitos $T$, a tolerância central também é moldada no timo, onde a enorme diversidade de linfócitos $T$ sofre um processo chamado de "seleção negativa" (ou deleção clonal), com a eliminação de linfócitos com alta afinidade por antígenos próprios; representando o principal mecanismo de tolerância imunológica central controlando a autoimunidade (KLEIN et al., 2014; TAKABA; TAKAYANAGI, 2017).

Mais especificamente, os linfócitos T CD4+ ou CD8+ selecionados positivamente na região cortical, migram para a região medular do timo, onde interagem com células apresentadoras de antígenos, como as células epiteliais tímicas medulares (mTECs) e as células dendríticas. As mTECs expressam 
uma grande quantidade de antígenos restritos a tecido (TRAs), que normalmente seriam encontrado apenas em tecidos específicos na periferia (DERBINSKI et al., 2001), e podem transferir alguns destes para as células dendríticas (HUBERT et al., 2011). As células T auto-reativas, que reconhecem complexos auto-antígeno-MHC com grande avidez, são deletadas neste microambiente. Como resultado, linfócitos $T$ Naive expressando um TCR funcional, e sem reatividade significativa aos auto-antígenos, podem deixar o timo e circular pelo corpo, migrando para órgãos linfoides secundários como 0 baço e os linfonodos (TAKABA; TAKAYANAGI, 2017).

Embora a deleção clonal de linfócitos com alta afinidade por antígenos próprios represente o principal mecanismo de tolerância imunológica que impede a autoimunidade, linfócitos apresentando afinidades intermediárias por auto-antígenos podem sobreviver ao processo de seleção negativa, podendo potencialmente contribuir para condições auto-imunes mediante sua ativação e expansão nos tecidos periféricos. Este cenário é impedido por mecanismos de tolerância periférica (ABBAS et al., 2004).

\section{Tolerância Periférica}

$\mathrm{Na}$ periferia, linfócitos $\mathrm{T}$ potencialmente auto-reativos podem permanecer inativos devido à baixa acessibilidade (ignorância) aos autoantígenos nos tecidos. Ainda, na ausência de sinais de perigo, as APCs não regulam as moléculas co-estimulatórias exigidas pelos linfócitos $T$ naïves para sua ativação; como resultado, a ligação do TCR na ausência de co-estimulação leva à anergia ou deleção do clone, protegendo contra a auto-imunidade (REDMOND; SHERMAN, 2005).

No entanto, em determinadas situações, estes mecanismos primários podem não atuar, de forma que células regulatórias especiais têm de entrar em jogo para evitar danos aos tecidos. Dentre outras, as células $T$ reguladoras (Tregs) são as principais responsáveis em regular a resposta imune e manter a tolerância periférica (SAKAGUCHI et al., 2008). Diversos tipos de células regulatórias existem, no entanto, a população mais estudada e que teria a maior relevância fisiológica são as células Treg $\mathrm{CD}^{+} \mathrm{CD} 25^{+} \mathrm{FOXP3}{ }^{+}$ 
(HORWITZ; ZHENG; GRAY, 2003; NISHIKAWA; SAKAGUCHI, 2010; SAKAGUCHI et al., 2006).

Os linfócitos Treg podem ser gerados no timo (tTregs ou nTregs, naturais) ou podem ser induzidas tanto in vivo perifericamente (pTregs) como in vitro (iTregs), a partir de linfócitos T naive (KANAMORI et al., 2016).

No timo, acredita-se que a diferenciação em Treg ocorre por um processo chamado de "seleção agonista", quando o TCR apresenta uma afinidade intermediária pelos auto-antígenos (ou TRAs) complexados ao MHC de classe II (apresentados pelas mTECs da na região medular); ou seja, nem demasiadamente forte para levar à deleção clonal nem demasiadamente fraca levando à geração de linfócitos T naive efetores (HOGQUIST; JAMESON, 2014; HSIEH; LEE; LIO, 2012; JORDAN et al., 2001; MORAN et al., 2011). Este mecanismo explicaria a existência de uma superposição apenas parcial dos repertórios de TCRs (com avidez intermediária contra auto-antígenos) entre as populações de linfócitos T naive e Treg (HSIEH et al., 2006).

Digno de nota, apesar de terem um papel fundamental na tolerância periférica as células tTreg também podem ser recrutadas por tumores durante o desenvolvimento do câncer, caracterizando um importante mecanismo de fuga do sistema imune (MALCHOW et al., 2013).

Além das nTregs tímicas, as pTregs induzidas na periferia também têm papel fundamental na tolerância periférica e no controle da autoimunidade; importantemente, desempenham um papel não redundante, uma vez que existe uma sobreposição mínima nos repertórios de TCRs entre nTregs e pTregs (HARIBHAl et al., 2011). Interessantemente, enquanto as nTregs possuem um repertório de TCR enviesado para auto-antígenos (resultante da seleção agonista mediada pela mTECs), acredita-se que as pTregs possuem um repertório de TCRs com afinidade por antígenos não próprios, oriundos de bactérias comensais (KUHN; STAPPENBECK, 2013; LATHROP et al., 2011), alimentos ingeridos, alérgenos na natureza (CUROTTO DE LAFAILLE et al., 2008) e do feto (no caso de uma mãe grávida) (SAMSTEIN et al., 2012). Por esta razão, as pTregs encontram-se altamente enriquecidas em locais de 
inflamação, especialmente nas superfícies mucosas e em órgãos específicos, como o intestino e a placenta materna (KANAMORI et al., 2016).

\section{Linfócitos T regulatórios}

Assim como as $n$ Tregs, tanto as $\mathrm{pTregs}$ geradas na periferia assim como as iTregs induzidas in-vitro também expressam o fator de transcrição FoxP3, que é descrito como um dos principais marcadores de células $T$ regulatórias, sendo responsável em grande parte por orquestrar a diferenciação (YAGl et al., 2004) e a função destas células (CHEN et al., 2003; HORI; SAKAGUCHI, 2004; LAL et al., 2009; TANG; BLUESTONE, 2008).

Apesar do marcador nuclear FOXP3 ser o mais importante para a caracterização das nTregs, em humanos elas podem ser caracterizadas pela expressão de um conjunto de marcadores de superfície nos linfócitos CD4+, destacando-se a elevada expressão de CD25 (SAKAGUCHI et al., 1995), a baixa expressão de CD127 (LIU, W. et al., 2006); além da expressão de CTLA4 (LIU, W. et al., 2006; READ; MALMSTROM; POWRIE, 2000; TAKAHASHI et al., 2000), GITR (MCHUGH et al., 2002; SHIMIZU et al., 2002), LAP (CHEN, M. L. et al., 2008) e TNFR2 (CHEN, X. et al., 2008).

Digno de nota o CD25 corresponde à cadeia a do receptor para IL-2, sendo expresso também por células $T$ efetoras ativadas (mas em níveis mais baixos), de tal forma que nos humanos somente a subpopulação $C D 4^{+} C D 25^{\text {hi }}$ está associada com a expressão de FOXP3 de células $T$ regulatórias (MELLANBY; THOMAS; LAMB, 2009).

As células $T$ regulatórias desenvolvem suas funções imunoregulatórias por diversos mecanismos (Figura 3), incluindo: a supressão por citocinas inibitórias e moléculas secretadas, como IL-10, TGF- $\beta$ e IL-35 (GREEN et al., 2003); a citólise mediada por granzimas e perforinas secretadas (GROSSMAN et al., 2004); a supressão mediada por adenosina (BORSELLINO et al., 2007; DEAGLIO et al., 2007); a indução de apoptose pelo consumo de IL-2 (PANDIYAN et al., 2007) e a inibição da maturação de células dendríticas em APCs maduras, mediada principalmente via CTLA-4, com a ativação de 
indoleamina-2-3-dioxigenase (IDO) e geração de um mediador imunossupressivo (GROHMANN et al., 2002).

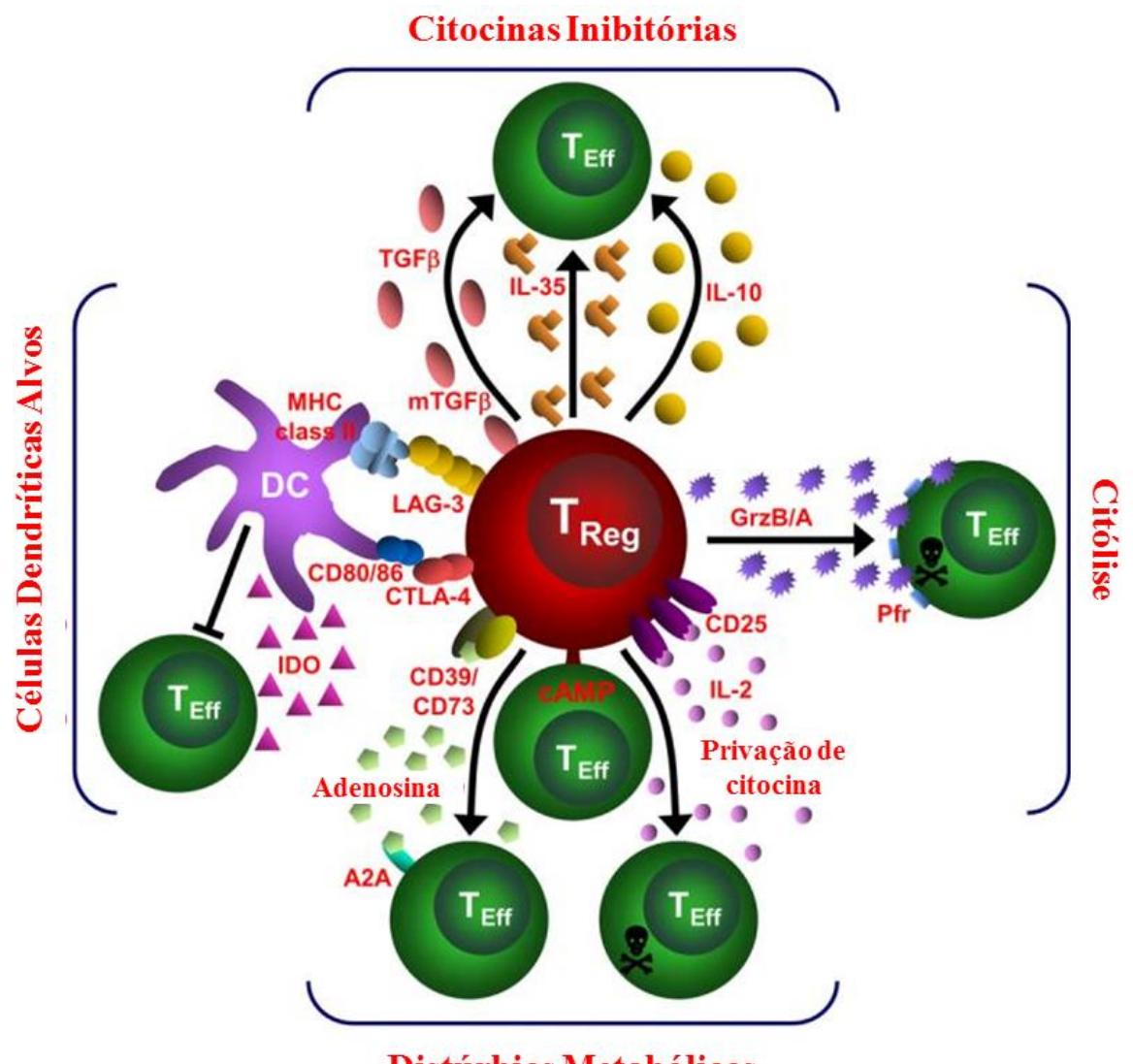

Figura 2. Mecanismos básicos utilizados pelas células Tregs. Este esquema descreve quatro mecanismos básicos da ação das Tregs. A supressão por ação das citocinas inibitórias, que incluem a IL-10, IL-35 e TGF- $\beta$. A supressão por citólise, dependente da granzima-A e granzima-B e perforina. A supressão por disfunção metabólica, que inclui apoptose mediada por privação de citocina dependente de alta afinidade pelo receptor IL-2 a (CD25), inibição mediada pelo AMP cíclico (cAMP), geração de CD39 e/ou CD73, e imunossupressão mediada pelo receptor de adenosina (A2A). Ou ainda, supressão causada por células dendríticas (DC) alvos, que inclui mecanismos moduladores da maturação e/ou função das DC, tais como a supressão da maturação das DC medida pelo gene-3 do complexo MHC de classe II. Adaptado de WORKMAN et al. (2009).

A manutenção da tolerância imune depende de um balanço entre as células $T$ regulatórias e as células $T$ auxiliares inflamatórias ( $T$ helper) (e.g. Th1 e Th17), o que garante a homeostase do sistema imune (AFZALI et al., 2007). A redução do número ou da função das Tregs está associada a diferentes doenças autoimunes (LONG; BUCKNER, 2011) e, portanto, as Tregs são consideradas potenciais ferramentas para o desenvolvimento de imunoterapias 
visando o reestabelecimento da tolerância imunológica em pacientes com diferentes patologias, incluindo: diabetes; encefalite; rejeição de órgãos transplantados ou em pacientes com a doença do enxerto contra o hospedeiro (GVHD), onde o sistema imune restabelecido a partir de células-tronco hematopoéticas de um doador de medula óssea (enxerto), ataca os tecidos do receptor hospedeiro (MAREK-TRZONKOWSKA et al., 2012; SCHMITT; WILLIAMS, 2013). Tendo em vista o enorme potencial clínico destas células, fica evidente a fundamental importância do estabelecimento de protocolos capazes de obter Tregs funcionais em número suficiente para as mais diversas aplicações possíveis.

\section{Geração de linfócitos Treg in vitro}

Como mencionado, as nTregs geradas no timo e as pTreg geradas a partir de linfócitos T CD4 naive nos tecidos periféricos diferem quanto ao repertório de TCRs e as diferenças entre estas células ainda não é bem estabelecida, no entanto, ambas compartilham várias propriedades e mecanismos imunosupressores (SHEVACH; THORNTON, 2014; YADAV; STEPHAN; BLUESTONE, 2013).

As nTregs poderem ser isoladas do sangue periférico (SP), porem em número usualmente insuficiente para terapias efetoras (LI et al., 2005); de forma que abordagens alternativas visam a expansão ex vivo baseadas no estímulo da via TCR em associação a IL-2, no entanto, com baixa reprodutibilidade (ALMEIDA et al., 2002; SALOMON et al., 2000). As nTregs também podem ser isoladas do sangue de cordão umbilical (SCU), entretanto, apresentam menor efeito supressor do que as oriundas do SP (LIU, J. et al., 2010), aparentemente em função da imaturidade fenotípica (MAYER et al., 2012).

Tanto as pTreg como as iTregs se diferenciam a partir de células $T$ CD4+ naïve (in vivo e in vitro, respectivemente) pela estimulação antigênica combinada à presença de citocinas apropriadas, incluindo IL-2 e o fator de crescimento transformador (TGF)-beta (BATTAGLIA; STABILINI; TRESOLDI, 2012; CHEN et al., 2003; FANTINI et al., 2004; FEUERER et al., 2009; 
HSIEH et al., 2012). Neste sentido, o SCU é considerado uma importante fonte alternativa destas células, por possuir um grande número de células $T$ naive (em contraste com o SP), com 90\% das células T CD3+ expressando CD45RA (MAYER et al., 2012). Ainda, os linfócitos possuem uma maior diversidade no repertório de TCRs e o SCU é uma fonte de fácil obtenção (sem riscos à mãe ou ao feto), com vários bancos públicos e privados contendo grandes coleções criopreservadas armazenadas (BARKER, 2007; CANTO; RODRIGUEZSANCHEZ; VIDAL, 2003; COHEN et al., 1998).

Interessantemente, células $T$ ativadas também se diferenciam em células Tregs quando cocultivadas com Células Estromais Mesenquimais (MSC) (MACCARIO et al., 2005; PREVOSTO et al., 2007), um grupo heterogêneo de células associadas à vasculatura encontradas em praticamente todos os tecidos e que desempenhariam papel no reparo tecidual e na homeostase do sistema imune (COVAS et al., 2008). Neste contexto, ao realizar um estudo transcriptômico do efeito das MSCs sobre linfócitos $T$ ativados (com partículas magnéticas ligadas a anticorpos anti-CD2/CD3/CD28, de forma a mimetizar células apresentadoras de antígenos), nosso grupo identificou um mecanismo inédito de imunomodulação mediada pelas MSCs. Mais especificamente, uma supressão na proliferação resultante (em parte) da sinalização da adenosina (produzida mediante o cocultivo) sobre o receptor ADORA2A nos linfócitos (SALDANHA-ARAUJO et al., 2011). Tendo em vista o importante papel imunomodulatório da adenosina (BORSELLINO et al., 2007; DEAGLIO et al., 2007; GORINI; LA SALA, 2008; KOBIE et al., 2006), estes achados levaram nosso grupo a investigar o potencial papel da modulação de componentes envolvidos na síntese da adenosina, e na sinalização mediada por ela.

\section{Papel da adenosina no controle da resposta imune nos tecidos}

A adenosina ( $A D O)$ é um nucleosídeo purínico endógeno que está constitutivamente presente em baixos níveis no meio extracelular, mas que pode ter seus níveis aumentados em condições patogênicas de inflamação, hipóxia, estresse metabólico e danos dos tecidos (SITKOVSKY, M.; LUKASHEV, 2005). 
A adenosina é composta pela subunidade heterocíclica nitrogenada adenina acoplada a um anel ribose por uma ligação $\beta$-N9-glicosídica, sendo gerada a partir do metabolismo de nucleosídeos purínicos como adenosina trifosfato (ATP), adenosina difosfato (ADP) e adenosina monofosfato (AMP) (Figura 1). As principais vias de biossíntese da adenosina são: a) através da desfosforilação da adenosina monofosfato (AMP) por enzimas 5' nucleotidases na região intracelular ou, b) pelo catabolismo extracelular mediante a desfosforilação sequencial do ATP em ADP e deste último em AMP, pela enzima ectonucleosídeo trifosfato desfosfohidrolase (CD39); seguido finalmente da desfosforilação do AMP em Adenosina pela enzima 5' nucleotidase (CD73) (ZIMMERMANN; ZEBISCH; STRATER, 2012).

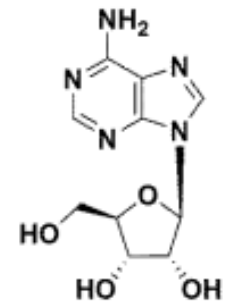

(1) Adenosina

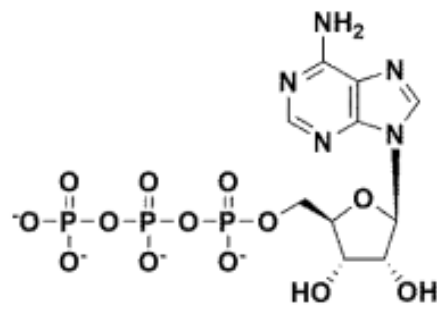

(2) ATP

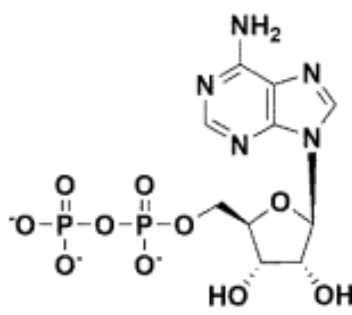

(3) ADP

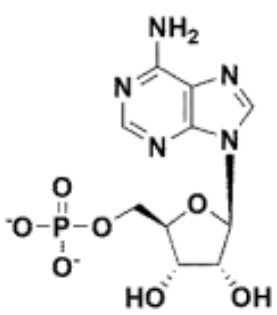

(4) AMP

Figura 3 Estrutura química da adenosina e de seus precursores adenosina trifosfato(ATP), adenosina difosfato (ADP) e adenosina monofosfato (AMP).

Durante a inflamação nos tecidos, ocorre um acumulo massivo de ATP, em parte por neutrófilos polimorfonucleares $(\mathrm{PMN})$, desencadeando inúmeras respostas. A hipóxia nestes tecidos leva a uma indução transcricional de CD39, CD73 e ADORA2B no endotélio, de forma que o ATP é convertido em ADO e, num segundo momento, os sinais de ADO sobre $A 2 b$ protegem a integridade vascular pela redução da permeabilidade do endotélio (ANTONIOLI et al., 2013; ELTZSCHIG et al., 2003).

A meia vida da adenosina no sangue é extremamente curta em humanos ( 15s) (SODERBACK; SOLLEVI; FREDHOLM, 1987) e, portanto, seu efeito é extremamente localizado atuando de forma autócrina ou parácrina; de forma a permitir uma inibição local do sistema imune nos tecidos mais lesionados, porem, garantindo a continuação da resposta imune contra patógenos nas imediações (SITKOVSKY, M. V.; OHTA, 2005). 


\section{Mecanismos imunomodulatórios da adenosina}

Os efeitos imunorregulatórios da adenosina são mediados pela ativação de receptores específicos (P1) acoplados a proteína $G$ (GPCRs, Gi/o), para os quais até agora foram identificados quatro subtipos: $A 1, A 2 A, A 2 B$ e $A 3$, codificados por Adora1, Adora2a, Adora2b e Adora3, respectivamente (FREDHOLM et al., 2011). Mais especificamente, os receptores de adenosina transduzem seus sinais por proteínas G que podem estimular (A2A e A2B) ou inibir (A1 e A3) a atividade da adenylyl cyclase e a consequente formação e acúmulo de AMP cíclico (cAMP) intracelular; sendo que linfócitos $T$ expressariam principalmente os receptores $A 2 a$ e A2b (THIEL; CALDWELL; SITKOVSKY, 2003). Importantemente, o receptor A3 também é acoplado a proteínas $\mathrm{Gq} / 11$ aumentando a produção de inositol P3 (JUNGER, 2011).

Os receptores de adenosina têm distintos perfis farmacológicos e de acoplamento ao ligante (OLAH; STILES, 1995; THIEL et al., 2003). Enquanto os receptores A1 e A2a são receptores de alta-afinidade, se ligando a baixas concentrações de adenosina (Ki na faixa de [pM] a [nM]) ou médias ([nM], respectivamente); os receptores $A 2 b$ e $A 3$ tem baixa afinidade pela adenosina, respondendo a altas concentrações (na faixa [uM]), usualmente associadas com condições patogênicas (CRONSTEIN; SITKOVSKY, 2017). Neste contexto, em tese, as respostas imunes iniciais nos tecidos inflamados, envolveriam principalmente os receptores $\mathrm{A} 1$ e $\mathrm{A} 2 \mathrm{a}$, frente às baixas concentrações de adenosina sendo liberadas; por outro lado, o aumento agudo de adenosina levaria à respostas dos receptores $\mathrm{A} 2 \mathrm{~b}$ e $\mathrm{A} 3$. Estas respostas dependeriam, entre outros fatores, do tipo e da quantidade de receptores expressos pelas células, assim como, da posição das células no tecido inflamado (SITKOVSKY, M. V.; OHTA, 2005).

A constante inibitória (Ki) de uma droga (agonista ou antagonista) é a concentração em que $50 \%$ dela se encontraria ligada ao seu alvo (na ausência de um ligante competidor). No entanto, diferente da afinidade de interação física do ligante com seu receptor (definida pelo Ki), a atividade biológica de um ligante sobre seu receptor é medida com base em ensaios funcionais que avaliam algum efeito bioquímico ou biológico, fornecendo um EC50, concentração onde se 
observa 50\% da atividade máxima (CHENG; PRUSOFF, 1973; KLOTZ et al., 1998; NEUBIG et al., 2003). Neste sentido, de acordo com estudos baseados no efeito da adenosina sobre a produção de AMPc intracelular, os receptores A1 e A3 teriam uma maior sensibilidade à adenosina ( $E C 50$ entre $0,2-0,5 \mu \mathrm{M}$ ), enquanto o receptor A2A teria uma sensibilidade um pouco menor (EC50 0,6-0,9 $\mu \mathrm{M}$ ); o receptor $A 2 B$ teria uma sensibilidade muito menor do que todos os outros subtipos de receptores (EC50 entre 16 e $64 \mu \mathrm{M}$ ) (JUNGER, 2011). Assim, os efeitos da adenosina em um determinado tecido são determinados de forma complexa, pela combinação da dinâmica de produção e eliminação da adenosina, e em função do repertório de receptores presentes nas células. Neste contexto, em baixas concentrações, a adenosina atuaria sobre os neutrófilos através dos receptores A1 e A3 promovendo quimiotaxia e fagocitose; enquanto que, em concentrações mais altas, a adenosina atuaria nos receptores de baixa afinidade A2A e A2B, inibindo o tráfico de neutrófilos e suas funções efetoras, como produção de mediadores inflamatórios e liberação de grânulos (BARLETTA; LEY; MEHRAD, 2012).

Diversos estudos demonstram que a ADO desempenha seu papel na supressão de células $T$ efetoras pela sinalização via receptor $\mathrm{A} 2 \mathrm{a}$, inibindo a ativação de TCR, evitando a fosforilação de ZAP70 e prejudicando a produção de IL-2, inibindo a expressão de CD25 e, consequentemente, reduzindo a proliferação celular. Além disso, após a ativação do receptor $\mathrm{A} 2 \mathrm{a}$, o desenvolvimento em células efetoras Th1, Th2 e Th17 é inibido, além de ocorrer um aumento dos reguladores negativos de ativação das células T: CTLA-4 e PD-1 (HASKO et al., 2008).

Ainda, as nTregs possuem altos níveis intracelulares de cAMP que pode ser transferido, por meio de "gap junctions", para células $\mathrm{T} \mathrm{CD4}{ }^{+}$convencionais onde $\mathrm{o}$ cAMP age como um potente inibidor da produção de IL-2 e subsequente proliferação destas células, caracterizando um mecanismo de inibição dependente de contato célula-célula (BOPP et al., 2007).

\section{Expressão de CD39 e CD73 e Produção de Adenosina pelas Tregs}

Dentre os mecanismos imunomoduladores das Tregs, a produção de adenosina a partir de ATP tem um papel importante e bem estabelecido em murinos, no entanto, existem diferenças consideráveis com as células de 
humanos; em especial, quanto à expressão das ectonucleotidases CD39 (codificada pelo gene Entpd1) e CD73 (codificada pelo gene Nt5e) (BORSELLINO et al., 2007; DEAGLIO et al., 2007; GORINI; LA SALA, 2008; KOBIE et al., 2006).

De modo geral, em linfócitos T CD4+ do sangue periférico de murinos naive a expressão de FoxP3 e CD25 se superpõe amplamente e definem a população de Tregs com potencial supressor; por sua vez, nos humanos a expressão de FoxP3 ocorre numa maior porcentagem apenas nos linfócitos T CD4+ com alta expressão de CD25 (CD25 ${ }^{\text {hi }}$ ), e numa menor porcentagem nos que expressam CD25 em menor intensidade $\left(\mathrm{CD} 25^{\circ 0}\right)$; de forma que apenas os Linfócitos $T$ $\mathrm{CD} 4+\mathrm{CD} 2{ }^{\mathrm{hi}} \mathrm{FoxP} 3+$ correspondem às Treg com potencial supressor. Em murinos CD39 e CD73 estão co-expressos na superfície das Tregs, conferindo-Ihes a capacidade produzir adenosina a partir de ATP de forma autônoma (BORSELLINO et al., 2007; DEAGLIO et al., 2007; KOBIE et al., 2006). Em humanos, CD39 não esta expresso em todos os linfócitos CD4+CD25+, mas preferencialmente nos linfócitos $\mathrm{CD} 4+C D 25^{\text {hi }}$ FoxP3+, portanto, enriquecido nas Tregs. Em total contraste com o observado em murinos, o marcador CD73 é praticamente ausente na superfície dos linfócitos CD4+ (cerca de 3\%), particularmente não sendo coexpresso com CD39 ou CD25. Assim, a ausência de expressão de CD73 na superfície das Tregs circulantes humanas, aparentemente as diferenciaria das murinas (BORSELLINO et al., 2007; DWYER et al., 2010; GORINI; LA SALA, 2008; MANDAPATHIL et al., 2009; SCHULER et al., 2011; SCHULER et al., 2012).

Importantemente, foi demonstrado posteriormente que no sangue periférico de humanos, CD73 também tem sua expressão enriquecida na população de linfócitos Treg $\mathrm{CD} 4+C D 25^{\text {hi }}$, porém, intracelularmente; sendo expresso numa baixa porcentagem dos linfócitos CD4+CD25- (MANDAPATHIL; HILLDORFER; et al., 2010).

Interessantemente, nos humanos, mediante ativação de leucócitos de sangue de doadores saudáveis (utilizando beads anti-CD3/CD28), a porcentagem de células expressando CD73 na superfície aumentaria consideravelmente (de $5 \%$ para $16 \%$ ) nas Tregs CD4+CD39+ (SCHULER et al., 2014). Ainda, mediante a indução in vitro de iTregs a partir de linfócitos 
CD4+CD25-, a porcentagem de linfócitos duplo positivos co-expressando CD39 e CD73 de superfície aumenta marcadamente, variando de 12 a mais de $40 \%$ (SCHULER et al., 2014). No entanto, estes trabalhos utilizaram um complexo método de indução que simula o nicho tumoral, dependendo da presença de varias citocinas, APCs dendriticas e células tumorais com características específicas (MANDAPATHIL; SZCZEPANSKI; et al., 2010; SCHULER et al., 2014).

Apesar das células CD4+CD39+ no sangue periférico de humanos serem capazes de hidrolisar ATP, não esta claro se a expressão de CD73 na superfície das Tregs é uma necessária para a completa hidrolise do ADP e AMP em adenosina. Tampouco, não está claro quais os mecanismos que governam a geração destas Tregs co-expressando CD39 e CD73 de superfície.

\section{Papel da adenosina e seus receptores na diferenciação de linfócitos Treg}

Como já mencionado, ao investigar os mecanismos envolvidos na supressão da proliferação de linfócitos $T$ ativados pelas MSCs, nosso grupo identificou a modulação de componentes envolvidos na síntese, degradação e sinalização da adenosina, como tendo um papel relevante neste contexto. Mais especificamente, o aumento dos níveis de adenosina seriam resultado do aumento de MSCs expressando CD39, em adição ao marcador CD73 tipicamente expresso na superfície das MSCs (aumentando a porcentagem de MSCs CD39+CD73+ de cerca de 10\% para 30\%), assim como de linfócitos Treg induzidos co-expressando CD39 e CD73 (SALDANHA-ARAUJO et al., 2011).

Neste mesmo contexto experimental, outro estudo permitiu a identificação da modulação de várias vias de sinalização nos linfócitos cocultivados com MSCs, em comparação a linfócitos ativados cultivados sozinhos (SALDANHA-ARAUJO, FELIPE et al., 2012). Em particular, foi demonstrado que a supressão proliferativa neste cenário experimental foi claramente acompanhada por uma repressão generalizada no nível dos transcritos de componentes relacionados à sinalização de TCR, incluindo CD3, LCK, Vav, ZAP70, LAT e GRB2 (SMITH-GARVIN; KORETZKY; JORDAN, 
2009), bem como de transcritos de componentes envolvidos na progressão do ciclo celular através da fase G1 (BOONSTRA, 2003). Ainda, enquanto a ativação da via canônica de NF-kappaB (downstream ao TCR) controlava a expressão precoce e transitória do marcador de ativação CD69, sua expressão tardia e sustentada como marcador de Tregs era promovida pelas MSCs através da via não-canônica, e inibida pela sinalização canônica (SALDANHAARAUJO, FELIPE et al., 2012).

Como um todo, os resultados acima indicavam que mediante o cocultivo, a produção aumentada de adenosina levaria à supressão da proliferação dos linfócitos via ativação de ADORA2A nos linfócitos, com consequente produção de cAMP intracelular e inibição da ativação da via TCR (HASKO et al., 2008).

Digno de nota, aumentos nos níveis intracelulares de cAMP também atuam inibindo a via mTOR, pela dissociação entre mTORC1 e mTORC2 e redução de sua atividade catalítica (XIE et al., 2011); uma via com importante papel na proliferação e sobrevivência de células T efetores (BATTAGLIA et al., 2006) e na diferenciação de células TH17 (KOPF et al., 2007). Assim, a sinalização da adenosina produzida por linfócitos Treg contribuiria para a anergia de linfócitos $T$ convencionais, pela sinalização via ADORA2A, aumento de cAMP intracelular e consequente inibição da atividade de mTORC1 (KALEKAR; MUELLER, 2017; OHTSUKA et al., 2010).

Importantemente, transcritos de componentes da via PI3K-AKT-mTOR (incluindo diferentes subunidades catalítica de PI3K, AKT1, AKT2, PDK1 e FKBP1A), estavam reprimidos em linfócitos $T$ co-cultivados com MSCs (em comparação aos não co-cultivados), indicando a inibição desta via (SALDANHA-ARAUJO, F. et al., 2012). Interessantemente, a inibição da via PI3K-AKT-mTOR em células $T$ ativadas tem um papel importante na indução de Foxp3 e na geração de linfócitos Treg (HAXHINASTO; MATHIS; BENOIST, 2008; SAUER et al., 2008), com a inibição de mTOR pela droga droga Rapamicina contribuindo para a expansão e função das Tregs (BATTAGLIA; STABILINI; RONCAROLO, 2005; KANG et al., 2008; ZEISER et al., 2008).

Frente o exposto, é possível que a inibição da via mTOR, por intermédio do aumento de CAMP decorrente da sinalização de ADO, poderia contribuir para a 
geração dos linfócitos Treg $C D 4+C D 25{ }^{\text {hi }} C D 73+C D 39+$ gerados mediante 0 cocultivo. Tendo em vista que linfócitos $T$ expressam principalmente os receptores A2a e A2b, ambos promovendo acumulo de cAMP via ativação da adenylyl cyclase (THIEL et al., 2003), ambos seriam os principais suspeitos na possível regulação da geração de Tregs, a princípio.

Entre as diversas abordagens passiveis de serem utilizadas para o estudo da função específica de diferentes receptores de adenosina no processo de diferenciação in vitro de linfócitos $T$ naíve em iTregs, o uso de agonistas e antagonistas farmacológicos se destacam, tendo em vista a praticidade de seu uso (FREDHOLM et al., 2011; JACOBSON; GAO, 2006). No entanto, seu uso deve ser feito com extrema precaução, uma vez que dependendo do fármaco e da concentração utilizada, a inibição ou ativação de um dado receptor pode não ser específica. De fato, o uso de concentrações inadequadas de diferentes fármacos, poderia explicar, ao menos em parte, os resultados divergentes encontrados nos poucos trabalhos que se propuseram a avaliar o papel de diferentes receptores de adenosina no processo de geração de linfócitos Treg. Em particular, enquanto dois trabalhos indicam que os receptores ADORA2A estariam envolvidos neste processo (OHTA et al., 2012; ZAREK et al., 2008), outros dois indicam a participação de ADORA2B (EHRENTRAUT et al., 2012; NAKATSUKASA et al., 2011) e ADORA1 (NAKATSUKASA et al., 2011).

Importantemente, todos os trabalhos mencionados acima, foram feitos em camundongos. Assim, além de não estar claro qual dos diferentes receptores de adenosina teria um papel na regulação do processo de geração de Tregs em camundongos, estes achados podem não se aplicar a humanos.

O entendimento dos mecanismos pelos quais iTregs funcionais são geradas in vitro é de grande valia, tanto para o estabelecimento de protocolos eficientes para sua geração e/ou expansão, como para o desenvolvimento de terapias voltadas para doenças autoimunes, doença do enxerto contra 0 hospedeiro, e no controle de rejeição de tecidos transplantados (RONCAROLO; BATTAGLIA, 2007). Tendo em vista as vantagens associadas com o uso do sangue de cordão umbilical, este trabalho teve como objetivo avaliar o papel da sinalização mediada por diferentes receptores de adenosina 
na geração de células $T$ regulatórias induzidas in vitro a partir de células $T$ CD4+ naive isoladas de sangue de cordão umbilical humano; em particular, investigando a expressão de iTregs co-expressando CD39 e CD73 de superfície. 
2- HiPóteSE 
A sinalização de adenosina por meio de seus receptores modula o processo de geração de linfócitos T regulatórios induzidos co-expressando CD39 e CD73 extracelular. 
3- OBJETIVOS 


\section{Geral}

Este trabalho teve como objetivo avaliar o papel da sinalização mediada por diferentes receptores de adenosina na geração de células $T$ regulatórias induzidas in vitro a partir de células T CD4+ naive de sangue de cordão umbilical humano.

\section{Específicos}

Gerar iTregs a partir de células T CD4+ naive de sangue de cordão umbilical, através da ativação por anticorpos anti-CD2, antiCD28 e anti-CD3, na presença de IL-2 e combinações de agonistas e antagonistas de receptores de Adenosina; caracterizando imunofenotipicamente as populações geradas, por citometria de fluxo, em particular, quanto à co-expressão de CD39 e CD73 de superfície;

Avaliar funcionalmente as populações geradas quanto a sua capacidade de suprimir a proliferação de linfócitos $T$, em ensaios utilizando CFSE;

Analisar a modulação de vias moleculares relacionadas com a indução de células T naive em Tregs, utilizando PCR em tempo real. 
4- Materiais E MÉtodos 


\section{Especificidade dos agonistas e antagonistas utilizados}

Ao iniciar este trabalho apresentamos questionamentos quanto à especificidade das drogas agonistas e antagonistas utilizadas nos trabalhos prévios da literatura. Estudos baseados no uso de fármacos drogas capazes de estimular (agonistas) ou inibir (antagonistas) determinados receptores sofrem com questões técnicas relacionadas à especificidade das drogas disponíveis. As diversas drogas agonistas ou antagonistas dos receptores de adenosina atuam principalmente de forma competitiva, ou seja, se ligando no mesmo sítio da adenosina. A especificidade de uma determinada droga por determinado receptor depende de sua afinidade pelo receptor, de forma que, numa determinada concentração os demais receptores não se liguem a esta droga. A constante inibitória (Ki) de uma droga (agonista ou antagonista) é a concentração em que 50\% dela se encontraria ligada ao seu alvo (na ausência de um ligante competidor). Em geral a Ki é determinado em ensaios de competição utilizando um radioligante; pela equação $\mathrm{Ki}=\mathrm{IC} 50 /(1+([\mathrm{L}] / \mathrm{Kd}))$, onde o IC50 é a concentração que o ligante competidor desloca $50 \%$ da ligação específica do radioligante, [L] é a concentração do radioligante utilizado e Kd é a constante de dissociação do radioligante (CHENG; PRUSOFF, 1973).

Quanto menor o Ki, maior a afinidade de ligação da droga pelo receptor. A especificidade de uma droga para um dado receptor é dada pela diferença do Ki da droga (para este receptor) para o Ki dos outros receptores (para a mesma droga). Assim, o uso de concentrações elevadas de uma droga pode levar à ativação ou inibição inespecífica de outros receptores. Apesar dos valores de Ki de uma droga não estarem diretamente associados com a sua potencia específica (i.e. efeitos funcionais biológicos), o Ki é um valor absoluto que não varia conforme o tipo de ensaio funcional, sendo uma boa referência para guiar o planejamento de estudos (KLOTZ et al., 1998; NEUBIG et al., 2003).

Assim, determinou-se que concentração utilizada para cada uma das drogas seria cinco vezes o valor do Ki específico para o receptor alvo, de forma a favorecer a completa ação somente o receptor de interesse, mantendo as concentrações distantes dos Kis dos outros receptores (Tabela 1). 
Tabela 1. Drogas agonistas e antagonistas de receptores de adenosina investigadas $e$ as suas afinidades para com os subtipos de receptores de adenosina humano, assim como seus valores de Ki.

\begin{tabular}{c|c|cccc}
\hline \multirow{2}{*}{ Composto } & & \multicolumn{4}{|c}{ Ki (nM) } \\
\cline { 2 - 6 } & $\begin{array}{c}{[]} \\
\text { Utilizada }\end{array}$ & A1 & A2a & A2b & A3 \\
\hline $\begin{array}{c}\text { Adenosina } \\
\text { (Agonista Geral) }\end{array}$ & & 100 & 310 & 15000 & 290 \\
$\begin{array}{c}\text { NECA } \\
\text { (Agonista Geral) }\end{array}$ & 700 & 14 & 20 & 140 & 6,2 \\
$\begin{array}{c}\text { CGS 21680 } \\
\text { (Agonista A2a) }\end{array}$ & $\mathbf{1 3 5}$ & 289 & $\mathbf{2 7}$ & $>10000$ & 67 \\
$\begin{array}{c}\text { ZM 241385 } \\
\text { (Antagonista A2a) }\end{array}$ & $\mathbf{8}$ & 774 & $\mathbf{1 , 6}$ & 75 & 743 \\
$\begin{array}{c}\text { CCPA } \\
\text { (Agonista A1) }\end{array}$ & $\mathbf{4 , 2}$ & $\mathbf{0 . 8 3}$ & 2270 & 18800 & 38 \\
$\begin{array}{c}\text { DPCPX } \\
\text { (Antagonista A1) }\end{array}$ & $\mathbf{1 5}$ & $\mathbf{3 . 0}$ & 129 & 51 & 795 \\
$\begin{array}{c}\text { MRS1191 } \\
\text { (Antagonista A3) }\end{array}$ & $\mathbf{1 5 0}$ & $>10000$ & $>10000$ & $>10000$ & $\mathbf{3 1 . 4}$ \\
$\begin{array}{c}\text { Cl-IB-MECA } \\
\text { (Agonista A3) }\end{array}$ & $\mathbf{7}$ & 220 & 5360 & $>10000$ & $\mathbf{1 . 4}$ \\
\hline $\begin{array}{c}\text { PSB 603 } \\
\text { (Antagonista A2b) }\end{array}$ & $\mathbf{2 , 8}$ & $>10000$ & $>10000$ & $\mathbf{0 , 5 5 3}$ & $>10000$ \\
\hline
\end{tabular}

* Devido a dificuldades técnicas relacionadas ao seu metabolismo extremamente rápido, os valores para Adenosina são estimativas derivadas de ensaios funcionais e, portanto, não refletem a real afinidade pelos receptores. NECA e Adenosina (YAN et al., 2003); CGS 21680 e ZM 241385 (JACOBSON; GAO, 2006); PSB 603 (BORRMANN et al., 2009). FREDHOLM et al. (2011).

As combinações utilizadas (Tabela 2) tiveram o intuito de garantir a avaliação isolada de cada receptor. 
Tabela 2. Combinações de drogas agonistas e antagonistas de receptores de adenosina investigadas.

\section{A1.1-Um ago + tres antago:}

\section{Para A1}

CCPA 4,2nM (agonista A1) e em conjunto:

MRS $150 \mathrm{nM}$ (antagonista A3) + ZM 8nM (antagonista A2a) + PSB 2,8nM (antagonista A2b)

A1.2- tres antagos:

MRS $150 \mathrm{nM}$ (antagonista A3) + ZM 8nM (antagonista A2a) + PSB 2,8nM (antagonista A2b)

A1.3- agonista sozinho:

CCPA 4,2nM (agonista A1)

A1.4- antago sozinho:

DPCPX 15nM (antagonista A1)

A1.5-antagonista mais agonista:

CCPA 4,2nM (agonista A1) + DPCPX 15nM (antagonista A1)

A2a.1- um ago + tres antago:

\section{Para A2a}

CGS 135nM (agonista A2a) e em conjunto:

MRS $150 \mathrm{nM}$ (antagonista A3) + DPCPX 15nM (antagonista A1) + PSB 55nM (antagonista A2b)

A2a.2- tres antago:

MRS $150 \mathrm{nM}$ (antagonista A3) + DPCPX 15nM (antagonista A1) + PSB 2,8nM (antagonista A2b)

A2a.3- ago sozinho:

CGS 135nM (agonista A2a)

A2a.4- antago sozinho:

ZM 8nM (antagonista A2a)

A2a.5- antago + ago:

ZM 8nM (antagonista A2a) + CGS 135nM (agonista A2a)

\section{Para A2b}

A2b.1-um ago + tres antago:

NECA 700nM (agonista) e em conjunto:

DPCPX $15 \mathrm{nM}$ (antagonista A1) + ZM 8nM (antagonista A2a) + MRS 150nM (antagonista A3)

A2b.2-tres antago:

DPCPX $15 \mathrm{nM}$ (antagonista A1) + ZM 8nM (antagonista A2a) + MRS 150nM (antagonista A3)

A2b.3- ago sozinho:

NECA 700nM (agonista)

A2b.4-antago sozinho:

PSB 2,8nM (antagonista A2b)

${ }^{*}$ A2b.5- antago+ago:

NECA 700nM (agonista) + DPCPX $15 \mathrm{nM}$ (antagonista A1) + ZM 8nM (antagonista A2a) + MRS 150nM (antagonista A3) + PSB 2,8nM (antagonista A2b)

*Em vista da falta de um agonista específico, esta condição teve de contar com todos os antagonistas 
Tabela 2. (continuação) Combinações de drogas agonistas e antagonistas de receptores de adenosina investigadas.

\section{A3.1- um ago e tres antago:}

\section{Para A3}

IB 7nM (agonista A3) e em conjunto:

DPCPX $15 \mathrm{nM}$ (antagonista A1) + ZM 8nM (antagonista A2a) + PSB 2,8nM (antagonista A2b)

A3.2- tres antago:

DPCPX $15 \mathrm{nM}$ (antagonista A1) + ZM 8nM (antagonista A2a) + PSB 2,8nM (antagonista A2b)

A3.3-ago sozinho:

IB 7nM (agonista A3)

A3.4-antago sozinho:

MRS 150nM (antagonista A3)

A3.5- antago + ago:

MRS 150nM (antagonista A3) + IB 7nM (agonista A3)

1-iTreg

\section{Controles}

TGFb e atRA

2-Controle

Sem tratamento

3-DMSO

DMSO a $0,002 \%$

4-inibindo os 4 com uma

ZM $5 \mu \mathrm{M}$

5-ativando todos com uma

NECA $5 \mu \mathrm{M}$

6-inibindo os 4 separado

MRS $150 \mathrm{nM}$ (antagonista A3) + ZM 8nM (antagonista A2a) + PSB 2,8nM (antagonista A2b) + DPCPX 15nM (antagonista A1)

Ao início deste trabalho, realizamos ensaios de viabilidade, bem como de geração de células Treg, com diferentes concentrações de uma droga agonista geral de receptores de adenosina (NECA), utilizando condições controle contendo o veículo DMSO em concentrações equivalentes (Apêndices a1 e a2). Esta avaliação inicial nos permitiu identificar que para evitarmos efeitos tóxicos ou inespecíficos do DMSO, sua concentração deveria ser mantida abaixo de $0,002 \%$. Assim, as drogas foram adquiridas e sua diluição foi inicialmente realizada conforme a indicação do fabricante e, posteriormente, utilizado o meio de cultura RPMI, garantindo assim, uma baixa porcentagem final de DMSO no meio de cultura. 


\section{Coleta do Sangue de Cordão Umbilical}

As amostras de células naive de sangue de cordão umbilical foram obtidas com consentimento dos responsáveis de acordo com projeto aprovado pela Comissão de Ética em Pesquisa do Hospital das Clinicas da USP de Ribeirão Preto e pela Comissão de Pesquisa da Mater (Centro de Referência para a Saúde da Mulher). O termo de consentimento livre e esclarecido foi apresentado aos responsáveis pela enfermeira Maria Fernanda Capeli, contratada da Mater, responsável pela coleta do material. As bolsas de sangue de cordão umbilical obtidas foram mantidas a $4^{\circ} \mathrm{C}$ até o momento do processamento (até 6 horas após a coleta) no qual foi utilizado todo o volume de sangue coletado. O número de amostras de sangue de cordão umbilical necessárias para o desenvolvimento deste projeto variou em função do sucesso obtido para a geração das Tregs. Portanto, estimou-se que seriam utilizadas 10 amostras de sangue de cordão umbilical para padronizar esse processo e realizar os ensaios funcionais de imunomodulação. Foram candidatas potenciais à doação de sangue de cordão umbilical as parturientes e seus filhos (independente de raça, classe social ou religião) atendidos no centro obstétrico (durante os anos de 2014 a 2017), entre as 12 horas de domingo até as 10 horas de sexta-feira com Idade gestacional acima de 35 semanas; peso fetal maior que $2800 \mathrm{~g}$; bolsa rota há menos de 12 horas. As gestantes foram submetidas aos exames laboratoriais para sífilis, doença de Chagas, hepatite B e C, HTLV I e II, HIV 1 e 2, toxoplasmose (sorologia para detecção de anticorpos $\operatorname{lgM}$ ) e citomegalovírus (sorologia para detecção de anticorpos totais e $\operatorname{lgM}$ ) e as amostras que apresentaram um ou mais resultados positivos foram descartadas.

\section{Obtenção de células naive de cordão umbilical}

De acordo com o desenho experimental proposto, dois métodos de separação foram utilizados neste projeto. Inicialmente, a população total de células naive (CD4+CD45RA+CD25-) foi isolada utilizando um kit comercial (Naive CD4+ T Cell Isolation Kit II, human; No. Cat. 130-091-894, Miltenyi Biotec-MACS). Assim, para depleção das células de memória e das demais células que não expressam CD4+ presentes na fração mononuclear do sangue de cordão, essas foram marcadas indiretamente incubando-as com um coquetel 
de anticorpos biotinilados anti- CD45RO, CD8, CD14, CD15, CD16, CD19, CD25, CD34, CD36, CD56, CD123, anti-TCRy/ס, anti-HLA-DR, e CD235a, segundo as especificações do fabricante. Posteriormente, as células marcadas foram ligadas a partículas magnéticas (microbeads) ligadas a anticorpos antibiotina. Finalmente, a suspensão celular foi passada por uma coluna separadora colocada num campo magnético. As células marcadas foram retidas na coluna enquanto que as células T naive foram eluídas com PBS (PBS, $2 \mathrm{mM}$ EDTA, $0,5 \%$ soro albumina bovina). O grau de pureza dessa separação foi analisado por citometria de fluxo e posteriormente as células foram submetidas às condições de cultura descritas a seguir.

\section{Condições de Cultura}

Um sistema comercial de ativação celular ( $\mathrm{T}$ Cell Activation/Expansion Kit, human, No Cat. 130- 091-441, Miltenyi Biotec-MACS) foi utilizado no intuito de induzir as Tregs. Este sistema utiliza partículas ligadas a anticorpos anti-CD2, anti-CD3 e anti-CD28, capazes de co-estimular os respectivos receptores fornecendo, concomitantemente com o uso de IL-2, os estímulos necessários para a ativação e proliferação das células $T$. Com a ativação das células $T$ naive ocorreu a geração de células T CD4+ efetores e iTregs. Para isso, padronizamos a quantidade ótima de TGF-beta e IL-2 para indução de células CD4+CD25hiFOXP3+. Assim, as células $T$ naive ativadas $\left(1 \times 10^{6}\right)$ foram cultivadas em meio de cultura, com adição de IL-2 recombinante $(50 \mathrm{U} / \mathrm{mL})$ e TGF-beta $(5 \mathrm{ng} / \mathrm{mL})$, e atRA $(100 \mathrm{nM})$ por 5 dias. Adicionalmente a esses estímulos foram utilizados combinações de rapamicina (100nM), agonistas dos receptores de ADO A2a (CGS21680) e agonistas dos receptores de ADO não seletivos (NECA). Além disso, combinações com antagonistas de receptores de ADO A2a (ZM241385) e A2b (PSB603) também foram utilizados no intuito de se observar o efeito inverso (diminuição da geração de iTregs). Após o período de indução, as culturas foram avaliadas quanto à presença de iTregs, caracterizadas por meio de um painel de marcadores imunofenotípicos (ver Citometria de Fluxo). 


\section{Imunofenotipagem por Citometria de Fluxo}

As células naive isoladas do SCU e as células obtidas após indução de Tregs em cultura foram avaliadas imunofenotípicamente. Em suma, alíquotas das amostras (contendo cerca de $1 \times 10^{5}$ células) foram incubadas com os anticorpos contra os marcadores a serem avaliados e com os controles de isotipo adequados. Após incubação com os anticorpos pertinentes (em geladeira por 20 min), os tubos foram centrifugados por 5 min a 2000 RPM a $5^{\circ} \mathrm{C}$, o sobrenadante descartado, e as células ressuspendidas em $2 \mathrm{~mL}$ de PBS azida contendo SBF. Os tubos foram novamente centrifugados por $5 \mathrm{~min}$ a $2000 \mathrm{RPM}$ a $5^{\circ} \mathrm{C}$, O sobrenatante descartado, e o pellet de células ressuspendido em 500 ul de PBS formol (1\%) para aquisição das células pelo citômetro (FACScalibur, Becton Dickinson). Os anticorpos conjugados a fluorescein isothicyanate (FITC), Rphycoerythrin (PE), allophycocyanin (APC) ou peridinin chlorophyll protein (PerCP) foram obtidos da BD-Biosciences.

Para a avaliação da pureza das células T CD4+ naive, obtidas imunomagnéticamente de $\mathrm{SCU}$, as células obtidas foram marcadas com os anticorpos anti-CD4, anti-CD25 e anti-CD45RA ${ }^{+}$(ou com um controle de isotipo). Um gate foi traçado com base nos parâmetros de FSC e SSC, para eliminar células mortas ou debris celulares, de forma a considerar apenas as células viáveis. Um novo gate foi então definindo nas células CD4+CD25- (não ativadas) e, finalmente, a porcentagem de linfócitos naive CD45RA+ foi determinada.

Para a avaliação das células obtidas após indução de Tregs in vitro, foram utilizados anticorpos contra CD4, CD25, CD39 e CD73. Este conjunto de marcadores permitiu a avaliação da porcentagem de linfócitos $T$ expressando CD39, CD73, ou ambos marcadores (CD39+CD73) em diferentes populações incluindo linfócitos T CD4+ totais, bem como nos linfócitos T CD4+CD25- e CD4+CD25+. 
A indução de Tregs após a utilização de diferentes combinações de rapamicina, agonistas e antagonistas de receptores de ADO na presença de IL2, TGFbeta e atRA foi avaliada através da expressão de Foxp3, em linfócitos T CD4+CD25hi e CD4+CD25+CD127-, duas populações celulares que nos permitem o seu isolamento para realização de ensaios funcionais.

\section{Isolamento das linfócitos T CD3+ efetores e Tregs CD4+CD25hi e CD4+CD25+CD127-}

Os linfócitos T CD4+CD25hi foram obtidos por sorting com uso do aparelho FACSAria Cell Sorting System (Becton Dickinson), e os linfócitos T CD4+CD25+CD127- foram isolados com 0 uso do kit comercial CD4+CD25+CD127dim/- Regulatory T Cell Isolation Kit II, human (No. Cat. 130094-775, Miltenyi Biotec-MACS) que inicialmente depleta as células que não expressam CD4 e também a população celular CD127+ (coquetel de anticorpos biotinilados anti-CD8, CD19, CD123, CD127) e posteriormente seleciona positivamente as células que expressam CD25. Já as células CD3+ foram obtidas por seleção imunomagnética positiva por uso de um kit comercial (CD3 MicroBeads, human; No. Cat. 130-050-101, Miltenyi Biotec-MACS).

\section{Ensaio funcional de supressão}

Após o cultivo por 5 dias, as populações geradas foram avaliadas funcionalmente quanto sua capacidade de suprimir a proliferação de linfócitos $T$ CD3+ através de ensaios com Carboxyfluorescein succinimidyl ester (CFSE). Portanto, os linfócitos gerados foram cultivados por 3 dias em placas com fundo em U com células CD3+ marcadas com 2,5 $\mu \mathrm{M}$ de CFSE e ativadas com beads (proporção 1 célula para 2 beads), na proporções Treg:CD3 (1:1 - 1:16). Após esse período essas células foram recolhidas e avaliadas por citometria de fluxo para análise da proliferação celular em linfócitos T CD3+. 


\section{Extração do RNA Total}

Após a realização dos ensaios foi extraído mRNA a partir de células T naive e iTregs. Para extração de mRNA, foi utilizada o reagente Trizol, seguindo o protocolo do fabricante. Em suma, foram utilizadas aproximadamente 1×106 células para cada extração. Após peletadas, foi adicionado às células o reagente de lise QIAzol e posteriormente clorofórmio. Após centrifugação, o homogenato foi separado em 2 fases: uma aquosa contendo o RNA total e outra orgânica contendo o DNA e proteínas. A fase aquosa foi recolhida e etanol foi adicionado para que todas as moléculas de RNA fiquem em condições de se ligarem a coluna. Essa mistura foi adicionada à coluna que posteriormente passa por uma centrifugação. Logo após, essa coluna foi lavada com os tampões do kit para que todos os contaminantes, como fenol, sejam retirados. Então, o RNA foi eluído pela adição de 30 ul de água tratada com DEPC na coluna e posterior centrifugação. A quantificação foi obtida utilizando 1ul da amostra, com o espectrofotômetro Nanodrop 1000 (ThermoScientific).

\section{PCR em Tempo Real}

PCR quantitativo em tempo real (Real time PCR) foi utilizado para análise da expressão de genes relacionados à geração de Tregs. Para isso, foi realizada a transcrição reversa de RNA total usando o High Capacity cDNA Archive Kit ou, no caso dos microRNAs, foram utilizados primers RT stem loop específicos (Applied Biosystems, Foster City, CA). A quantificação relativa dos genes selecionados foi realizada utilizando controles endógenos adequados para normalização interna das amostras. As reações foram realizadas em duplicata utilizando mix de sonda e primers TaqMan ("Assay on demand") em conjunto com o reagente MasterMix (Applied Biosystems, Foster City, CA). A reação foi realizada no equipamento 7300 Real Time PCR System (Applied Biosystems). A expressão gênica relativa foi calculada, pela fórmula 2- $\Delta \Delta C$ T (Pfaffl 2001). 


\section{Quantificação de citocinas}

A dosagem das citocinas foi realizada por meio da técnica Cytometric Bead Array (CBA) (BD, Pharmingen, EUA) que se baseia no uso de esferas de poliestireno marcadas com diferentes graus de fluorescência, recobertas com anticorpos específicos, que são detectados nos canais FL3 ou FL4. Esse sistema permite uma análise quantitativa das citocinas marcadas com ficoeritrina em função do deslocamento dos grupamentos em FL2 obtidos por citometria de fluxo (Fig. 3.1). A metodologia CBA foi adaptada do protocolo original proposto pelo fabricante, com algumas modificações: alíquotas de 25 $\mathrm{mL}$ de amostra foram utilizadas e $25 \mathrm{~mL}$ dos padrões das citocinas submetidos à diluição seriada com diluente $G$ do kit CBA. As amostras e os padrões foram transferidos para tubos de poliestireno de $5 \mathrm{~mL}$ e foram adicionados $15 \mathrm{~mL}$ da mistura de esferas de captura, conjugadas com anticorpos monoclonais anticitocinas IL-2, IL-6, IL-8 e IL-10 (Human Th1/ Th2/Th17 Cytokine Kit, BD, Pharmingen, EUA; Catalog. n. 560484). Em seguida, $18 \mu \mathrm{L}$ do coquetel de anticorpos foram conjugados com PE e incubados por 3 horas, à temperatura ambiente. Após a incubação, as esferas de captura foram lavadas e centrifugadas a $340 \mathrm{~g}$, por 7 minutos, a $18 \stackrel{\circ}{ } \mathrm{C}$ e o sobrenadante foi descartado. Os dados foram adquiridos em citômetro de fluxo (FACSAria, BD, E.U.A.) e analisados com auxílio do software específico para CBA (FCAP Array TM Software, BD, Pharmingen, EUA), por meio de curvas de calibração obtidas dos padrões de citocinas do kit. Após a construção das curvas, a concentração dos analitos na amostra foi determinada $\mathrm{em} \mathrm{pg} / \mathrm{mL}$, a partir dos valores de Intensidade Média de Fluorescência (MFI) obtidos na leitura da Fluorescência 2, sendo os resultados expressos em $\mathrm{pg} / \mathrm{mL}$.

\section{Quantificação de adenosina produzida pelos linfócitos nas diferentes condições de modulação farmacológica dos receptores de adenosina}

Ao final dos cinco dias de todos os tratamentos, o sobrenadante das culturas foi coletado para quantificação de adenosina por espectrometria de massa. As amostras $(1000 \mu \mathrm{L})$ obtidas foram armazenadas a $-80^{\circ} \mathrm{C}$ até 0 processamento. Como padrão, utilizamos a adenosina com pureza superior a 
$\geq 99 \%$ (A4036, Sigma). A cada sobrenadante de cultura adicionou-se $66 \%$ de acetonitrila, seguido de agitação em vórtex durante 1 min e centrifugação a 12000 rpm para extrair proteínas e estabilizar a adenosina. Em seguida, $40 \mu \mathrm{L}$ de sobrenadante recolhido foram novamente suspensos em $80 \mu \mathrm{L}$ de água pura. As amostras da curva de calibração consistiram em $40 \mu \mathrm{L}$ de meio com diferentes concentrações de adenosina $(0,5 \mu \mathrm{g} / \mathrm{mL}, 0,1 \mu \mathrm{g} / \mathrm{mL}, 0,05 \mu \mathrm{g} / \mathrm{mL}$, $0,01 \mu \mathrm{g} / \mathrm{mL}, 0,005 \mu \mathrm{g} / \mathrm{mL}$ e $0,0 \mu \mathrm{g} / \mathrm{mL}$ ) e adição de $80 \mu \mathrm{L}$ de agua. As separações de cromatografia líquida foram realizadas utilizando um sistema Xevo TQ-S Waters Acquity UPLC HSS com coluna C18 Acquity UPLC HSS com 1,0x150 mm. A temperatura do forno de coluna foi ajustada a $40^{\circ} \mathrm{C}$. $\mathrm{O}$ sistema solvente consistia em ácido acético a $0,1 \%$ em água e ácido acético a $0,1 \%$ em metanol. O caudal foi ajustado para $500 \mu \mathrm{L} / \mathrm{min}$ e utilizou-se um volume de injecção de $5 \mu \mathrm{L}$. O tempo de execução total foi de $6 \mathrm{~min}$. Os fragmentos iônicos observados foram m/z 268 e m/z 136 em modo positivo. Utilizou-se meio (sem adição de adenosina) como amostra em branco. Para obter um modelo de regressão para a curva de calibração, foi feita uma série de diluição de seis concentrações de adenosina em meio. Por concentração, foram analisadas três repetições e avaliada a linearidade. As concentrações de adenosina e as razões de área de pico foram calculadas utilizando o software Skyline 3.6.0.10493 MacCossLab - Department of Genomic Sciences - UW. 


\section{Obtenção dos linfócitos T Naive de sangue de cordão umbilical}

A população total de células $T$ naive $\left(C D 4^{+} C D 45 R A^{+} C D 25\right)$ isoladas imunomagneticamente a partir das bolsas de sangue de cordão umbilical, foram analisadas por citometria de fluxo para determinação da pureza (Figura 3). As amostras utilizadas neste trabalho tiveram uma porcentagem de pureza média de 94\%.
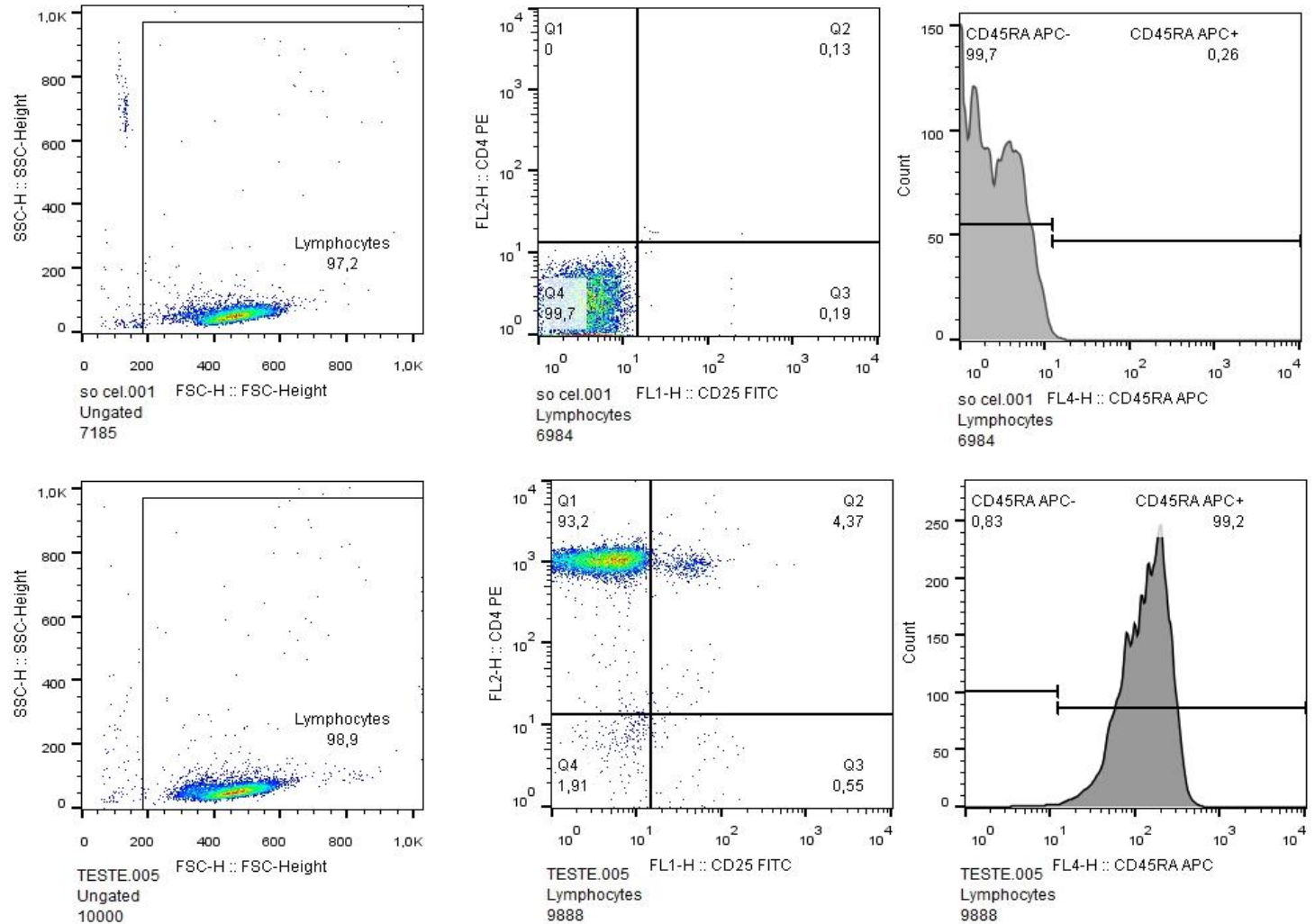

Figura 4. Avaliação por citometria de fluxo da pureza das células T CD4+ naive obtidas imunomagnéticamente de SCU. Após a separação imunomagnética as células foram marcadas com os anticorpos anti-CD4, anti-CD25 e anti-CD45RA ${ }^{+}$(parte inferior) ou com um controle de isotipo para normalização (parte superior). Após traçarmos um gate, com base nos parâmetros de FSC e SSC, para eliminar células mortas ou debris celulares (dot plots à esquerda), avaliamos a porcentagem de células CD4+CD25- não ativadas (centro) e CD45RA+ com fenótipo naive (direita). 
Expressão gênica de ADA, CD39, CD73 e receptores de adenosina em linfócitos $T$

Inicialmente, avaliamos os níveis de expressão de ADA, CD39, CD73 e receptores de adenosina em linfócitos $T$ naive CD4+CD25-RA+ recém isolados de sangue de cordão umbilical, e após ativação (com beads antiCD2/CD3/CD28) e cultivo por cinco dias, apenas na presença de IL-2, ou com a adição de TGF-beta e atRA uma condição descrita por nosso grupo como capaz de gerar iTregs com perfil imunofenotípico e funcional amplamente caracterizados (SCHIAVINATO et al., 2017). Apesar da variação observada, de maneira geral, os níveis dos transcritos de ADORA2A, ADORA2B, ADA e CD39 foram reduzidos mediante ativação dos linfócitos (com ou sem atRA/TGF-beta), com mudanças estatisticamente significativas em alguns casos. Em contrapartida, os níveis de expressão de ADORA1 e CD73 tiveram um aumento mediante a ativação, em comparação Às células $T$ naive. 
ADORA1

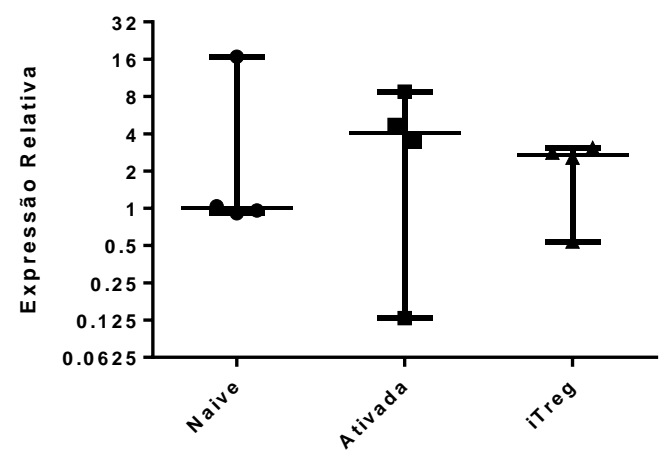

ADORA2B

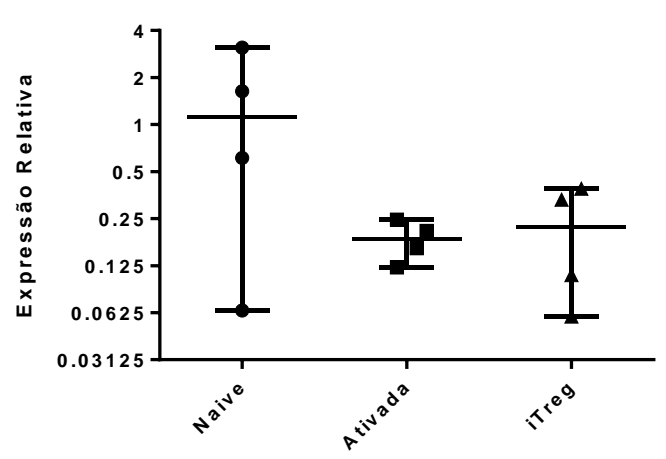

CD39

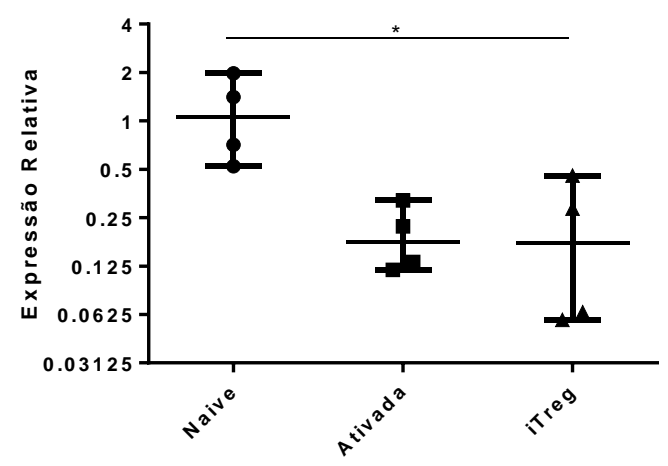

ADORA2A

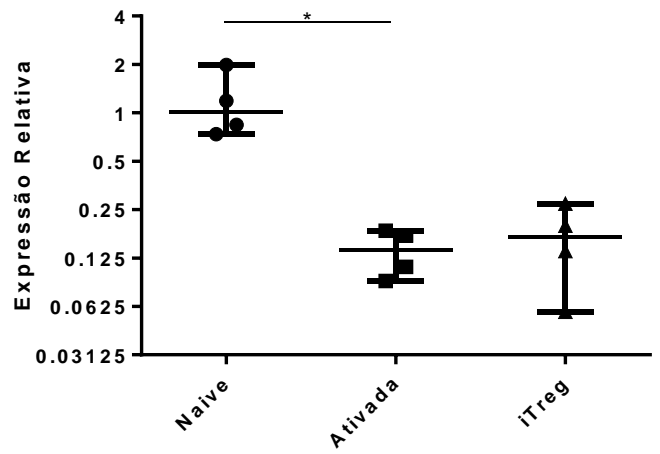

AD A

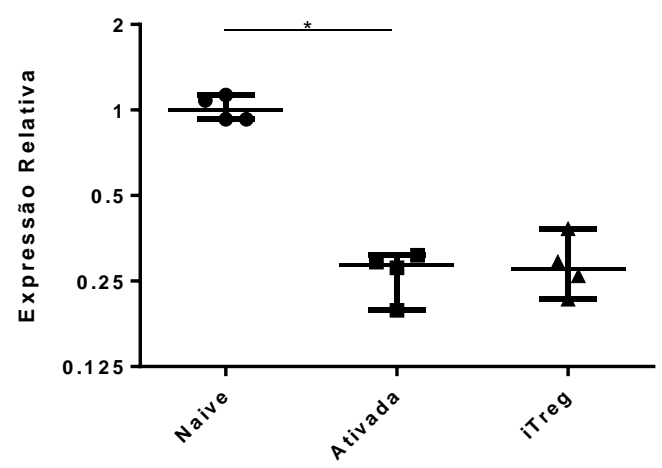

CD73

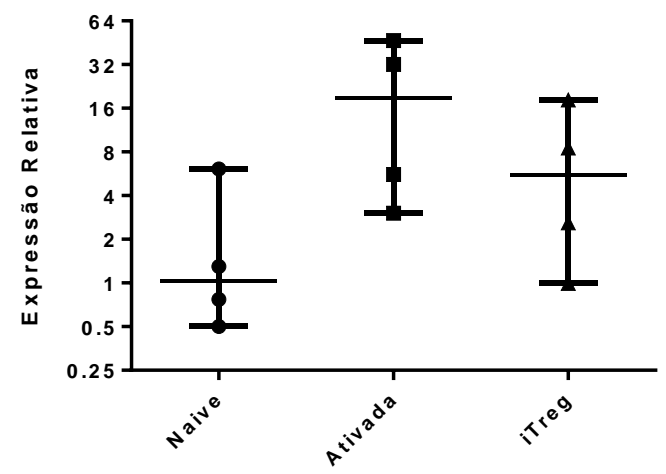

Figura 13. Expressão gênica relativa de receptores de adenosina, de ADA adenosina deaminase, de CD39 e Cd73 . Linfócitos T naive isolados de sangue de cordão umbilical ( $T$ naive) foram ativados com beads anti-CD2/CD3/CD28 e incubadas com IL-2 (Ativada) ou na presença de TGF $\beta$ e atRA (iTregs). Após cinco dias de cultivo, a expressão gênica de ADA, CD39, CD73 e dos receptores de adenosina (A1, $A 2 a$ e $A 2 b)$ foram determinadas nas três condições, utilizando PCR em tempo real. GAPDH foi utilizada como gene endógeno para o cálculo do DeltaCt (DCt). foram utilizadas como referência para o cálculo da expressão relativa, utilizando o método de $2^{\wedge} \mathrm{DDCT}(\mathrm{N}=4$, quatro bolsas de SCU). One-way ANOVA, pós teste Dunn (não paramétrico). 
Efeito da modulação farmacológica dos receptores de adenosina na geração de iTregs expressando CD39 e CD73 de superfície

Para avaliar o papel dos diferentes receptores de adenosina na geração de diferentes populações de células $T$ regulatórias (incluindo células CD4+CD25+ e CD4+CD25-), realizamos experimentos utilizando um conjunto de condições com as drogas agonistas e antagonistas descritas e avaliamos as populações geradas, utilizando citometria de fluxo. Com o intuito de induzir a geração de Tregs, linfócitos T naive CD4+CD25-CD45RA+ isolados do sangue de cordão umbilical, foram ativados utilizando beads anti-CD2/CD3/CD28 e cultivados com IL-2 (condição controle sem droga). Adicionalmente, foram utilizadas combinações de drogas agonistas e antagonistas dos receptores de adenosina, conforme as concentrações descritas e apresentadas nas Tabelas 1 e 2 .

As células ativadas e tratadas foram mantidas em cultura por 5 dias sem troca ou adição de meio de cultura, garantindo a concentração das drogas assim como os estímulos contidos em cada condição, posteriormente foram observadas as características imunofenotípicas das populações geradas.

A co-expressão de CD39 (ENTP1) e CD73 (5NTD) na superfície das células $T$ CD4+CD25+, caracterizam uma população de células reguladoras capazes de gerar adenosina extracelular a partir de ATP, ADP e AMP; assim, avaliamos as porcentagens de células expressando estes marcadores sozinhos ou simultaneamente.

A figura 4 ilustra a estratégia de gates utilizada para exclusão de fragmentos celulares e demais eventos artefatuais adquiridos pelo aparelho (Figura 4, dot plot à esquerda), e para definição das populações CD4+ e/ou CD4+CD25+ (Figura 4, dot plot à direita), nas quais foram determinadas as porcentagens de células CD39+, CD73+e CD39+CD73+ (Figura 5 e 6). 

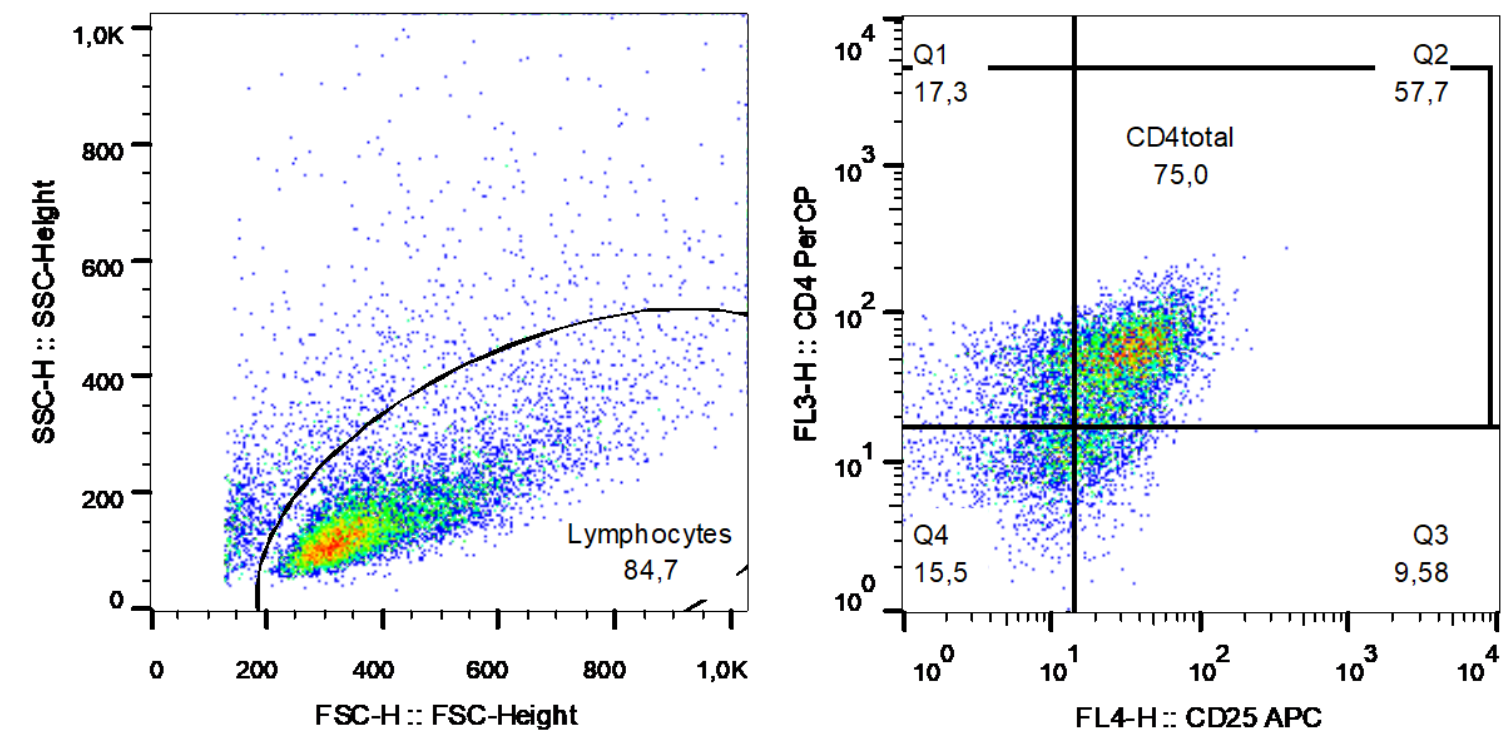

Figura 4. Dot plot representativos com a estratégia de gates para definição das populações analisadas quanto à percentagem de células CD39+ e CD73+. Inicialmente, um gate foi definido na região dos linfócitos, utilizando um plot de tamanho por complexidade interna (FSCXSSC), de forma a excluir beads, células mortas ou debris celulares da análise (esquerda); em seguida, as populações CD4 ${ }^{+}$ total e $\mathrm{CD}^{+} \mathrm{CD}^{2} 5^{+}(\mathrm{Q} 2)$ foram definidas com base num segundo plot (direita).

\section{Avaliação Inicial: Papel dos receptores A2A e A2B na geração de iTregs expressando CD39 e CD73 de superfície}

Num primeiro momento, utilizamos um conjunto de condições reduzido para tentar confirmar os achados da literatura, tentando avaliar apenas o papel dos receptores $\mathrm{A} 2 \mathrm{~A}$ e $\mathrm{A} 2 \mathrm{~B}$ na geração de populações de células regulatórias CD4+CD39+CD73+. Assim, linfócitos Naive CD4+CD25-RA+ isolados foram ativados e cultivados apenas na presença de IL-2, ou com a adição de diferentes combinações de agonistas e antagonistas.

Utilizamos o agonista genérico NECA a 100nM, concentração acima do Ki dos receptores A1, A2a e A3; e pouco abaixo do Ki de A2b. Para o agonista preferencial do receptor A2A (CGS) também utilizamos $100 \mathrm{nM}$, concentração $4 \mathrm{x}$ acima do $\mathrm{Ki}$ do receptor $\mathrm{A}_{2 \mathrm{a}}(\mathrm{Ki}=27), 10 \mathrm{x}$ menor que o $\mathrm{Ki}$ do receptor $\mathrm{A} 1$ $(K i=289 n M)$, e totalmente sem ligação esperada para $A_{2 b} \quad(K i>10000 n M)$; porem, um 1,5x acima do Ki para A3 (67nM). Para o antagonista preferencial de A2A (ZM), utilizamos uma concentração de $25 \mathrm{nM}, 15$ vezes acima de seu Ki $(1,6 n M)$, porém, evitando efeito sobre os outros receptores (Ki entre 75 e $774 n M)$. Finalmente, para o antagonista específico de $A_{2 b}$ (PSB), utilizamos 
uma concentração de 10uM. A concentração de PSB de 10nM seria mais do que suficiente para a completa inibição de $A_{2 b}(K i=0,55)$, no entanto, por erro, utilizamos 1000 vezes mais. Apesar disso, esta inibição continuaria específica, uma vez que o Ki para os outros receptores é >10000nM (10uM).

Como pode ser notado na figura a seguir, as porcentagens obtidas de células CD39+ e CD73+ nas diferentes condições avaliadas foram similares. Tendo em vista a relevância da co-expressão de CD39 e CD73 na superfície dos linfócitos (caracterizando células com potencial de produção autônoma de adenosina e, portanto, com capacidade supressora); visando simplificar a interpretação, apresentamos e discutimos apenas os resultados relativos à geração de células $C D 4+C D 39+C D 73+$. Em seu trabalho, Ohta relata que o uso do agonista genérico NECA e preferencial de A2A CGS (a 1uM) em culturas mistas de linfócitos murinos, levam a um aumento na população de células CD4+CD39+CD73+, oque ele atribui à sinalização de A2a OHTA et al. (2012). Em linha, comparado à condição controle com DMSO (sem droga) nossos resultados também revelaram um aumento na porcentagem de células CD4+CD39+CD73+ mediante tratamento com NECA e CGS, de cerca de $20 \%$ nos linfócitos ativados e cultivados apenas com IL-2, para cerca de $50 \%$ nas condições com a adição de ambas as drogas. Intrigantemente, e em aparente contradição com este suposto papel positivo do receptor $\mathrm{A} 2 \mathrm{a}$, ao inibirmos os receptores $A_{2 a}$ (utilizando o antagonista $Z M$ ), ao invés de suprimirmos a geração de células CD4+CD39+CD73+, observamos um surpreendente aumento destas células, alcançando cerca de $90 \%$ de todas as células CD4+. Estes resultados indicariam que sinais provenientes de A2a estariam inibindo a geração de células CD4+CD39+CD73+, uma vez que utilizamos uma concentração de $25 \mathrm{nM}$ de $Z M$, garantindo plena inibição de $A_{2 a}$, porém, evitando efeito sobre os outros receptores ( $\mathrm{Ki}=75 \mathrm{nM}$ para $\mathrm{A} 2 \mathrm{~B}$ e $>743 \mathrm{nM}$ para A1 e A3). Curiosamente, Ohta em seu trabalho, omitiu as condições de tratamento que combinam este inibidor com os agonistas NECA e CGS.

Ainda, o aumento na porcentagem de células CD4+CD39+CD73+, mediante inibição de $\mathrm{A} 2 \mathrm{a}$ por $\mathrm{ZM}$, foi totalmente contraposto na presença combinada do agonista genérico NECA (utilizado em concentração acima dos Kis de A1, A2a e A3) e do agonista preferencial de A2A CGS utilizado em 
concentração acima dos Kis de A2a e A3), mais uma vez sugerindo que a ativação do receptor $A_{2 a}$ teria um efeito negativo na geração de células CD4+CD39+CD73+. Dado que o inibidor específico de $A_{2 b}$ (PSB) não teve nenhum efeito sozinho e reduziu em pouco o efeito de NECA ou CGS, concluímos que o efeito positivo destes agonistas não seria mediado pelo receptor $A_{2 b}$. Com isto em vista, o aumento de células CD4+CD39+CD73+, observado mediante $o$ tratamento com os agonistas NECA e CGS, poderia ser explicado por um efeito positivo sobre os receptores $A_{3}$ e/ou também de $A_{1}$ (no caso de NECA). Dado que a concentração de NECA e CGS utilizada por nós (100nM) poderia estar estimulando tanto o receptor $A_{1}(\mathrm{Ki}=100 \mathrm{nM}$ e $289 \mathrm{nM}$, respectivamente) quanto $A_{3}(\mathrm{Ki}=290 \mathrm{nM}$ e $67 \mathrm{nM}$, respectivamente), estes resultados indicariam que o receptor $A_{1}$ ou $A_{3}$ poderiam ser responsáveis pelo efeito positivo observado na geração de células CD4+CD39+CD73+. Com estes resultados iniciais, decidimos expandir nosso estudo para investigar o papel específico dos receptores A1 e A3 neste contexto. 


\section{A}

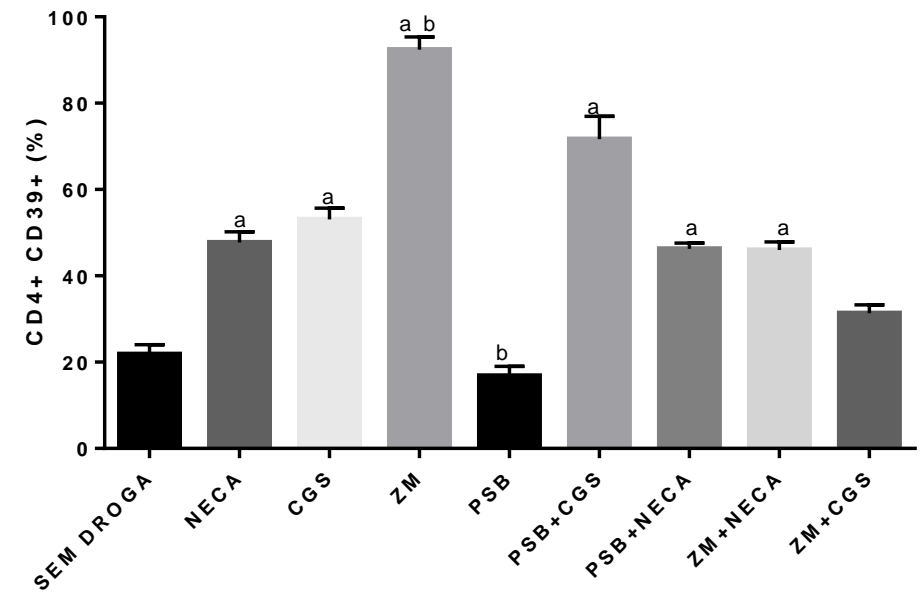

B

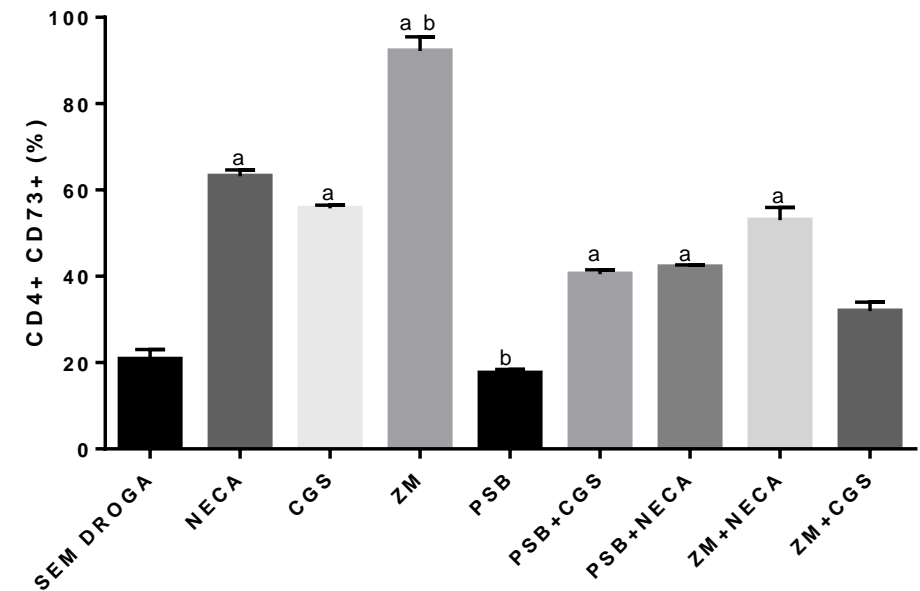

C

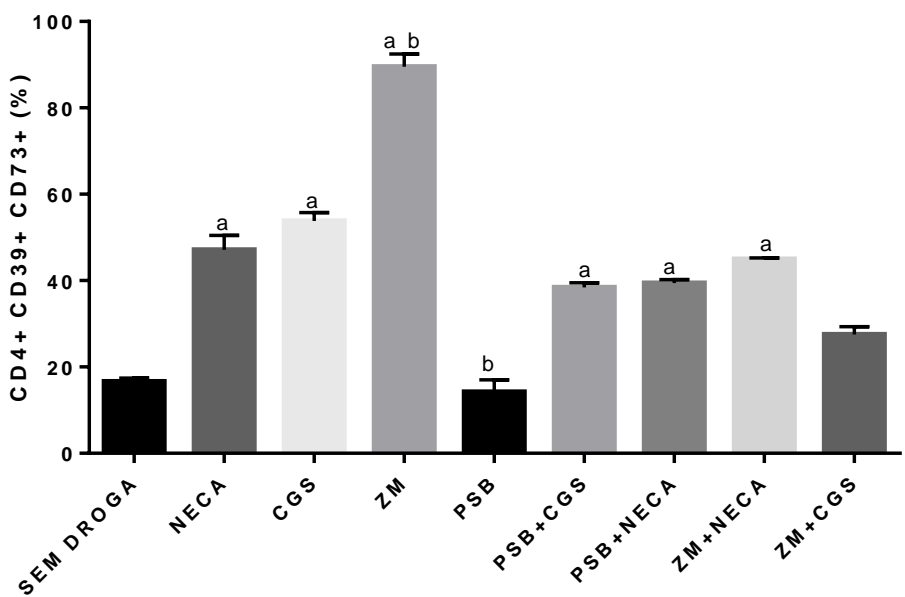

Figura 5. Efeito da modulação farmacológica dos receptores de adenosina (A2a e A2b) na geração de iTregs expressando CD39 e CD73 de superfície. Linfócitos T naive isolados de sangue de cordão umbilical foram ativados com beads anti-CD2/CD3/CD28 e incubadas com IL-2 sem droga (controle) ou na presença de agonistas e antagonistas farmacológicos dos receptores de adenosina. Após cinco dias de cultivo, as porcentagens de linfócitos positivos para CD39, CD73 ou ambos marcadores (CD39+CD73+) foram determinadas dentro da população CD4+, utilizando citometria de fluxo. A) Porcentagem de linfócitos CD39+. B) 
Porcentagem de linfócitos CD73+. C) Porcentagem de linfócitos duplo positivos CD39+CD73+. "a" se refere significância estatística $(p<0,05)$ entre a condição SEM DROGA e todas condições contendo drogas; "b" se refere a significância estatística $(p<0,05)$ entre a condição CGS (Agonista A2a) versus outros tratamentos. Células derivadas de um único doador em triplicata experimental. One-way ANOVA, pós teste Tukey.

\section{Papel dos diferentes receptores de adenosina na geração de iTregs expressando CD39 e CD73 de superfície}

Com o objetivo de avaliarmos o papel de todos os quatro receptores de adenosina, sobre a geração de linfócitos iTreg CD4+CD25+ expressando CD39 e CD73 de superfície, utilizamos diferentes combinações de agonistas e antagonistas. Novamente, linfócitos Naive CD4+CD25-RA+ isolados foram ativados e cultivados apenas na presença de IL-2 (Controle), ou com a adição de diferentes combinações de agonistas e antagonistas. Ainda, uma condição controle com DMSO foi utilizada para identificar possíveis efeitos inespecíficos do mesmo. Adicionalmente, incluímos uma condição similar à condição controle, mas com a adição de TGF-beta e atRA (iTreg), uma condição descrita por nosso grupo como capaz de gerar iTregs com perfil imunofenotípico e funcional amplamente caracterizados (SCHIAVINATO et al., 2017). Finalmente, avaliamos duas condições com o agonista genérico NECA (Pan-Ago) numa concentração de 5uM suficiente para ativar todos os receptores, outra com todos os quatro antagonistas (4-Inhib), e outra com o agonista preferencial de A2A ZM a 5uM, concentração muito acima dos Ki de A1, A2a, A3, mas não A2b (ZM-5uM). Todas as outras combinações foram repetidas para cada um dos receptores, consistindo de: Agonista específico + os inibidores específicos dos outros 3 receptores (Ago+3-Inhib), inibidores específicos dos outros 3 receptores (3-Inhib), agonista específico sozinho (Ago), antagonista específico sozinho (Inhib), agonista específico + inibidor específico (Ago+Inhib).

Mais uma vez, visando simplificar a interpretação, apresentamos e discutimos apenas os resultados relativos à geração de células CD39+, CD73+ e duplo-positiva CD39+CD73+, dentro da população CD4+CD25+. Os demais resultados, relativos às porcentagens dentro da população total de linfócitos CD4+ ou CD4+CD25-, são apresentados no apêndice. Digno de nota, de maneira geral, as porcentagens observadas dentro da população CD4+ corresponderam às observadas nas CD4+CD25+. 
A

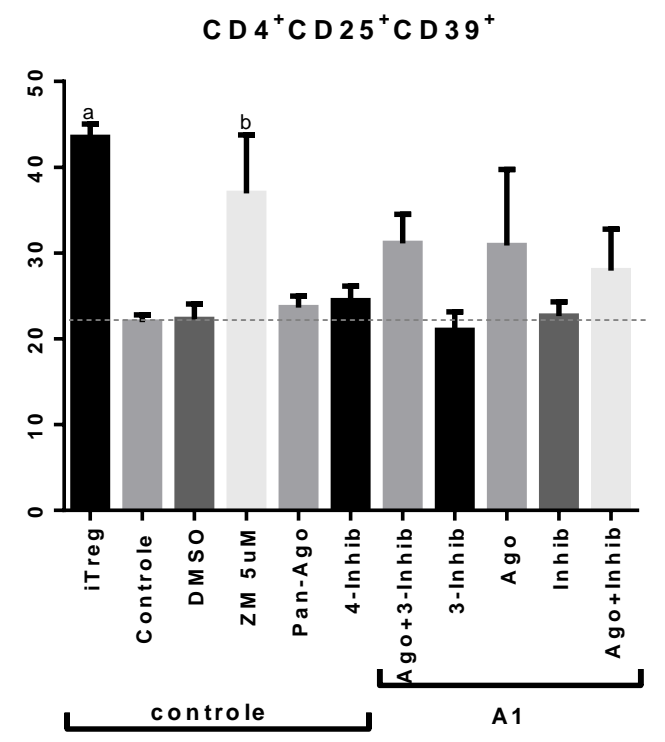

C

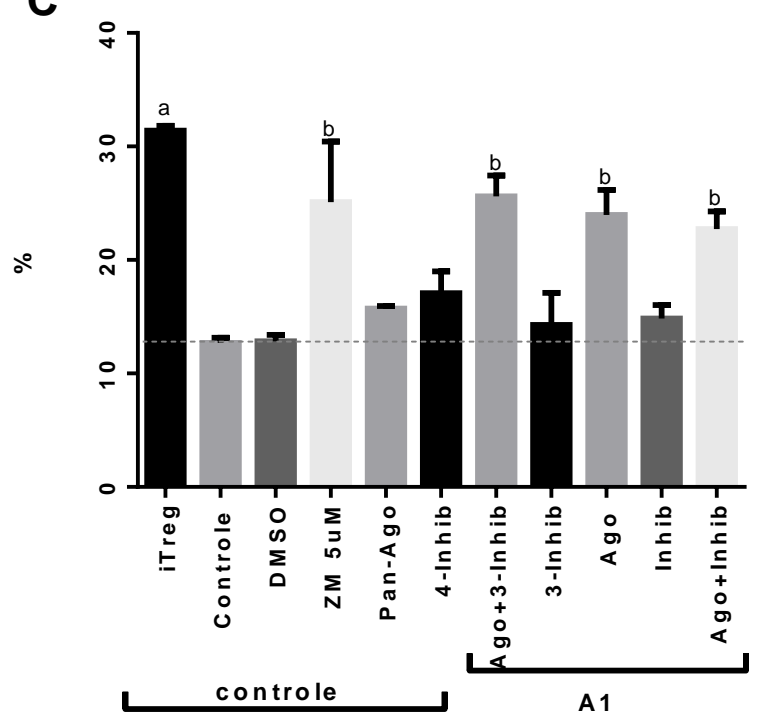

B

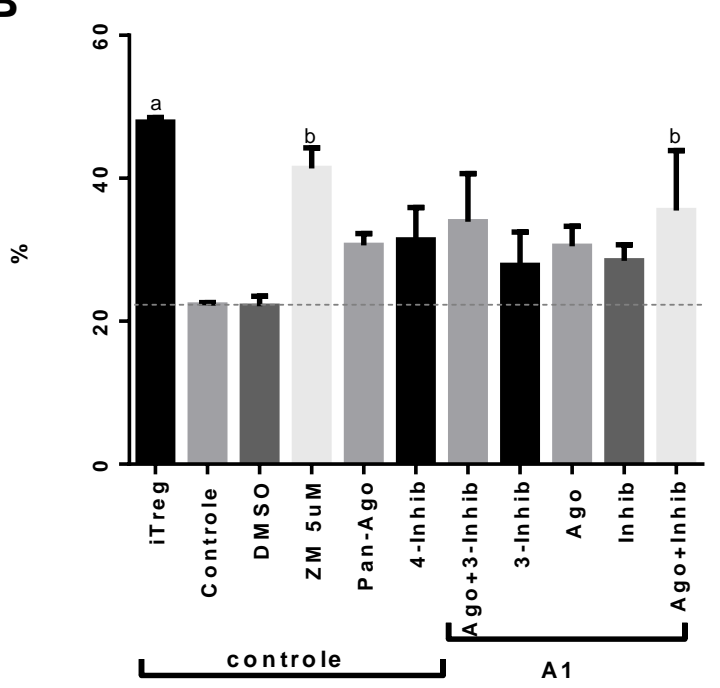

D

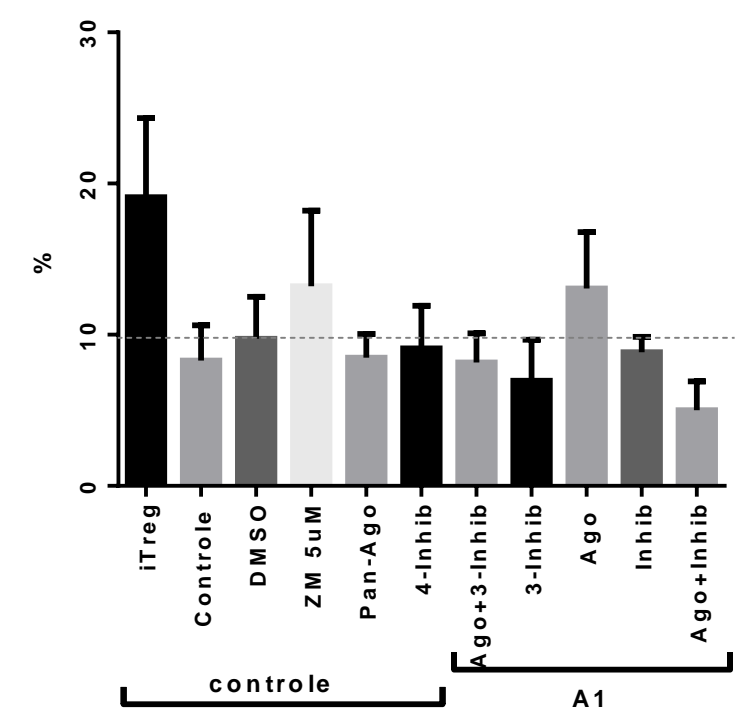

Figura . Expressão média das ectonucleotidases CD39+ e CD73+. A) Porcentagem de células CD39+ na população CD4+CD25+. B) Porcentagem de células CD73+ na população CD4+ CD25+. C) População CD39+ CD73+ avaliada na população CD4+ CD25+. D) População CD39+CD73+ avaliado na população CD4+ CD25high. A linha tracejada demonstra a média do tratamento controle. Valores expressos como média \pm SD.One-way ANOVA, pós teste Tukey. "a" se refere a significância estatística $(p<0,05)$ entre condições iTreg versus controles; "b" se refere significância estatística $(p<0,05)$ entre a condição DMSO e todas condições contendo drogas. $\mathrm{N}=3$, duplicata experimental. 
Primeiramente, avaliamos se a condição contendo DMSO teria algum efeito inespecífico nas características avaliadas, comparando-a com a condição controle contendo apenas linfócitos $T$ naive ativados e cultivados por cinco dias na presença de IL-2. Absolutamente nenhum efeito foi observado, garantindo uma avaliação segura das outras condições contendo as diferentes combinações de drogas. Digno de nota, na condição controle, a quantidade de DMSO correspondia à maior quantidade de DMSO presente nas outras condições.

Em seguida comparamos a condição de indução de iTregs contendo linfócitos ativados e cultivados na presença de IL-2 e com a adição de TGFbeta e atRA (iTregs), previamente estabelecida e totalmente caracterizada por nosso grupo (SCHIAVINATO et al., 2017). Surpreendentemente, nesta condição, a expressão de CD39 e CD73 de superfície foi induzida em mais de $40 \%$ dos linfócitos CD4+CD25+, sendo que cerca de $30 \%$ destes eram duplopositivos CD39+CD73+. Importantemente, esta diferença foi estatisticamente significativa, quando comparada com a condição controle sem adição de atRA ou TGF-beta.

Tendo em vista os resultados anteriores, decidimos novamente avaliar os efeitos do análogo de adenosina NECA agonista genérico dos receptores (Pan-Ago) neste contexto, porem, utilizando uma concentração 50 vezes maior (5uM) que a anteriormente utilizada $(0,1 \mathrm{uM})$. Novamente, observamos um aumento nas porcentagens de linfócitos expressando CD39 e CD73, no entanto, não significativas estatisticamente e bem menores que as observadas anteriormente. De maneira geral, isto indica que a sinalização sobre todos os receptores de adenosina teria como efeito líquido a geração de CD4+CD25+CD39+CD73+.

Também em vista os resultados anteriores, decidimos novamente avaliar os efeitos do antagonista ZM, também numa concentração muito maior (5uM) que a anteriormente utilizada $(0,1 \mathrm{uM})$, ao menos seis vezes acima dos Ki de todos os receptores. Mais uma vez, observamos uma maior geração de duplopositivos, estatisticamente significativa, mas com porcentagens bem inferiores ao experimento anterior. Ainda, as porcentagens foram mais variadas e 
inferiores à condição iTreg. Ao avaliarmos a condição com os quatro antagonistas específicos (cada um em concentração 5 vezes acima dos Ki dos respectivos receptores preferenciais), também pode-se notar um leve aumento nas porcentagens de CD39 e CD73. Isto exemplifica a complexa regulação destes receptores, associada à integração entre os efeitos opostos dos diferentes receptores promovendo ativação ou inibição da adenilil ciclase; de forma que o resultado líquido depende dos níveis de expressão dos diferentes receptores na superfície das células.

Finalmente, avaliamos 0 efeito do agonista específico do receptor $\mathrm{A} 1$ (CCPA) da adenosina. Importantemente, a porcentagem de linfócitos duplopositivos CD39+CD73+ aumentaram de forma estatisticamente significativa em todas as condições contendo o agonista, com a população duplo-positiva alcançando cerca de $25 \%$ dos linfócitos $C D 4+C D 25+$, porcentagens próximas à condição iTreg gerada na presença de atRA e TGF-beta. Em contraste, o antagonista específico de A1 (DPCPX) não teve efeito algum na concentração utilizada (Inhib), mesmo quando colocado juntamente com o agonista (Ago+Inhib). Digno de nota houve uma redução notável (mas não significativa estatisticamente) na porcentagem de linfócitos CD39+CD73+ quando avaliamos a população $C D 4+C D 25 h i$, indicando um efeito específico do agonista CCPA sobre o receptor A1. A falta de efeito observado provavelmente se deve às concentrações utilizadas do antagonista. Embora ambas drogas (agonista e antagonista) tenham sido utilizadas numa concentração cinco vezes acima do $\mathrm{Ki}$, tendo em vista o mecanismo de competição pelo sítio de ligação no receptor, o resultado líquido da condição Ago+Inhib seria a de termos uma redução de cerca de $50 \%$ na ligação do agonista. Desta forma o efeito positivo de CCPA sobre o receptor A1 seria suficiente mesmo em concentrações mais baixas. 


\section{Papel do receptor $\mathbf{A} 1$ de adenosina no perfil de citocinas}

Com o objetivo de avaliar o possível impacto das modulação do receptor A1 na produção de citocinas, quantificamos os níveis de IL-2, assim como das interleucinas inflamatórias IL-6 e IL-8, e da interleucina imunomodulatória IL-10 nas diferentes condições de modulação farmacológica do receptor $A 1$. Pode-se observar que os níveis de IL-10 nas condições com o agonista específico do receptor A1 (CCPA) contêm concentrações significativamente superiores que as condições nas quais o antagonista específico DPCPX foi adicionado; indicando que as condições com mais linfócitos CD4+CD25+CD39+CD73+ produziriam mais IL-10. Ainda, curiosamente, a condição com o agonista e 0 antagonista levou a um aumento estatisticamente significativo nos níveis de IL2.
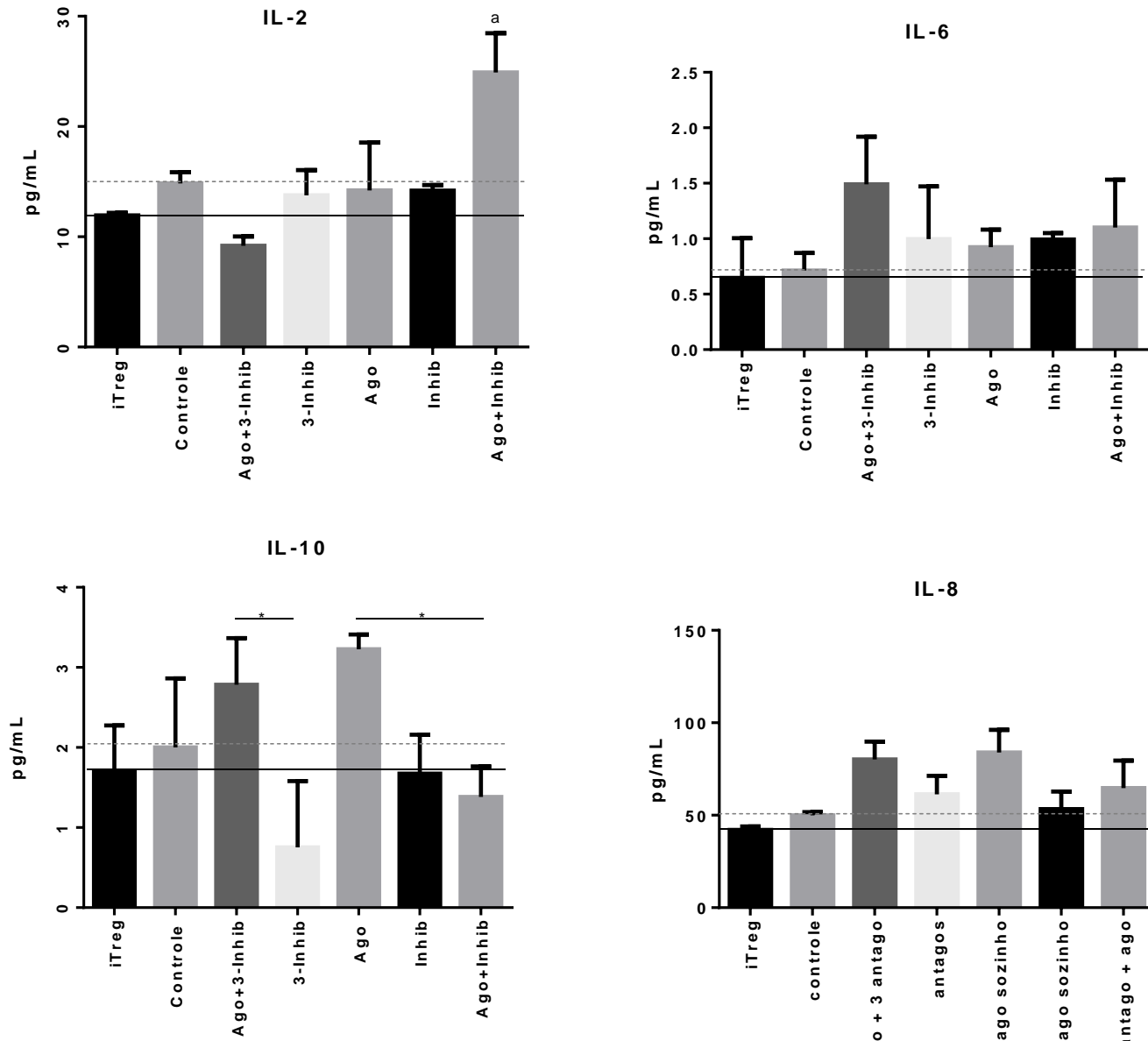

IL -8

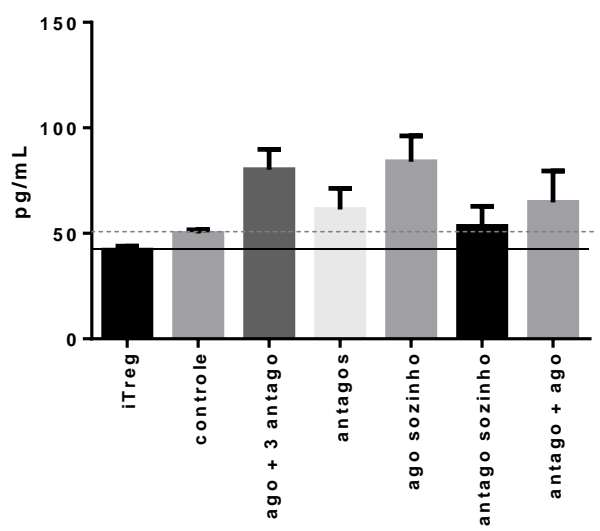

Figura 5. Quantificação de IL-2, IL-6, IL-8 e IL-10 no sobrenadante das células Tregs geradas em tratamentos focados no receptor A1. O sobrenadante foi 
coletado após o quinto dia de cultivo e os níveis das citocinas foram mensurados por CBA. Os valores acima foram expressos como média \pm SD. Teste $t$, pós teste Tukey. ${ }^{*} \mathrm{p}<0,05 . \mathrm{N}=2$, triplicata experimental

\section{Produção de adenosina nas condições de agonismo ou antagonismo do receptor A1 de adenosina}

Com o objetivo de avaliarmos a produção de adenosina pelos linfócitos gerados nas condições de cultivo na presença do agonista e do antagonista específico do receptor $A 1$ de adenosina, os linfócitos $T$ naive de sangue de cordão umbilical foram ativados com beads anti-CD2/CD3/CD28 e cultivados na presença apenas de IL-2 (controle), ou na presença adicional do agonista específico CCPA do receptor A1 (A1-Ago), ou seu antagonista específico (A1Inhib). Após cinco dias, a concentração de adenosina foi determinada por espectrometria de massas (em colaboração com o laboratório de proteômica do câncer chefiado pelo Prof. Vitor Faça). Como pode ser observado, em relação à condição controle, enquanto os níveis de adenosina na condição com o agonista do receptor $A 1$ foi elevada, a condição contendo o antagonista de A1 levou a uma redução na concentração de adenosina no meio. Ainda, houve uma redução estatisticamente significativa, quando compradas as duas condições.

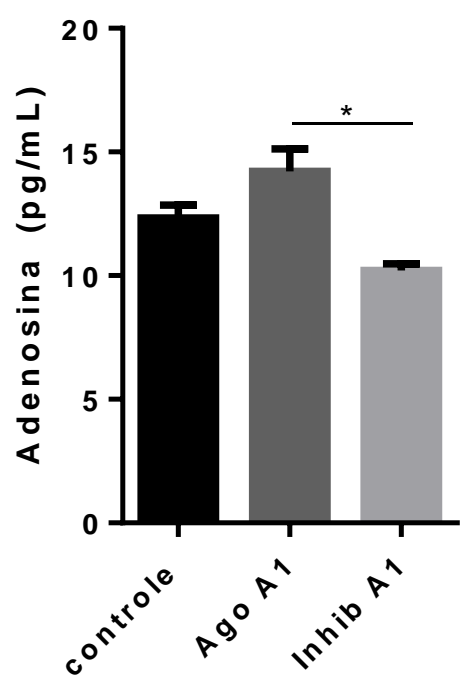

Figura 6. Concentração de adenosina presente no sobrenadante da cultura. Após 
a ativação e cultivo dos linfócitos T naive por cinco dias, na presença apenas de IL-2 (controle), ou na presença adicional do agonista específico CCPA do receptor A1 de adenosina (A1-Ago), ou seu antagonista específico (A1-Inhib), a concentração de adenosina (em picogramas $/ \mathrm{mL}$ ) foi determinada por espectrometria de massas.

Triplicata experimental $(\mathrm{N}=1)$. 
6- Discussão 
No presente estudo, nós demonstramos que linfócitos $T$ humanos CD4+CD25+ co-expressando CD39 e CD73 de superfície podem ser induzidos in vitro, a partir de linfócitos $T$ naive de sangue de cordão umbilical, mediante ativação mimetizando sinais via TCR (beads anti-CD2/CD3/CD28) e na presença de IL-2. Mais importante, nos demostramos que o receptor A1 de adenosina tem um efeito positivo na indução desta população, levando à geração de células produzindo níveis mais altos de adenosina e de IL-10.

Como mencionado anteriormente, no sangue periférico de murinos CD39 e CD73 estão co-expressos na superfície das Tregs CD4+CD25+FoxP3+, conferindo-Ihes a capacidade produzir adenosina a partir de ATP de forma autônoma (BORSELLINO et al., 2007; DEAGLIO et al., 2007; KOBIE et al., 2006). Em humanos, somente CD39 esta expresso preferencialmente na superfície dos linfócitos $\mathrm{CD} 4+\mathrm{CD} 25^{\mathrm{hi}} \mathrm{FoxP} 3+$; em contraste, CD73 esta praticamente ausente na superfície das Tregs (BORSELLINO et al., 2007; DWYER et al., 2010; GORINI; LA SALA, 2008; MANDAPATHIL et al., 2009; SCHULER et al., 2011; SCHULER et al., 2012), mas está presente (também de forma enriquecida) intracelularmente (MANDAPATHIL; HILLDORFER; et al., 2010).

Apesar dos muitos relatos evidenciando a ausência de CD73 na superfície de linfócitos humanos, dois relatos na literatura identificaram a expressão de CD73 na superfície de linfócitos T regulatórios gerados in vitro, no entanto, apenas mediante um complexo sistema de cocultivo simulando o nicho tumoral; dependendo da presença de varias citocinas, além de APCs dendriticas e células tumorais com características específicas (MANDAPATHIL; SZCZEPANSKI; et al., 2010; SCHULER et al., 2014).

Um dos primeiros trabalhos a descrever a produção de adenosina por linfócitos T em murinos, bem como sua capacidade inibir a produção de citocinas e a proliferação de células Th1 e Th2, foi Kobie et.al. (KOBIE et al., 2006). Mais especificamente, seu trabalho mostrou uma alta expressão de CD73 em Tregs CD25+ e FoxP3+ de murinos, assim como sua baixa expressão em linfócitos CD25- e FoxP3-; além de demonstrar a capacidade de ambas as populações de converterem AMP extracelular em adenosina (KOBIE et al., 2006). 
Em linha, em murinos, CD39 é expresso em grande parte (cerca de 2/3) das Tregs CD4+FoxP3+ (tal qual o marcador CD25), enquanto que os linfócitos FoxP3praticamente não expressam CD39 (ou CD25). Ainda, CD73 é igualmente expresso em cerca de 2/3 das Tregs CD4+FoxP3+, e apenas em cerca de 1/3 dos linfócitos FoxP3-; no geral, indicando que CD39 poderia servir como marcador de Tregs, assim como CD25 (BORSELLINO et al., 2007). Ainda em murinos, linfócitos T CD4+CD25-, negativos para CD39 na superfície, passam a expressa-lo mediante ativação do TCR. Nas Tregs, já positivas para CD39, a expressão aumenta em intensidade (apresentando uma correlação linear com os níveis de FoxP3) e, importantemente, a atividade catalítica de CD39 só aparece após a ativação de TCR nas Tregs (BORSELLINO et al., 2007). A ativação funcional de CD39, mediante ativação dos linfócitos, poderia estar ligada à palmitoilação na região intracitoplasmática $\mathrm{N}$-terminal de CD39, que promove uma interação mais forte com a membrana celular e uma localização preferencial de CD39 nas regiões caveolares da membrana (KOZIAK et al., 2000; SAUER et al., 2008).

Os achados de Borselino são corroborados por um estudo independente feito por Deaglio et.al (também em murinos), que mostrou a co-expressão de CD73 e CD39 associada à expressão de FoxP3 e de CD25; além de mostrar que linfócitos CD4+ expressando o marcador de ativação CD25 hidrolisam ATP de 8 a 10 vezes mais que linfócitos negativos para CD25 (DEAGLIO et al., 2007).

Digno de nota (também em murinos), estudos de expressão gênica revelaram que os níveis dos transcritos de FoxP3 e CD39 também estão altamente correlacionados, o que evidenciaria um potencial mecanismos de corregulação transcricional destes genes (DEAGLIO et al., 2007; FONTENOT et al., 2005; GAVIN et al., 2007). De fato, além da ativação de TCR (que induz FoxP3), a expressão forçada de Foxp3 também induz a expressão de CD39, corroborando a possível existência de um mecanismo de regulação compartilhado destes dois marcadores (BORSELLINO et al., 2007).

Em humanos saudáveis, em contraste com a grande associação de CD39 com CD25 e FoxP3 observada em murinos, Borselino relatou que a porcentagem de células CD39+ dentro da população de Tregs $\mathrm{CD} 4+\mathrm{CD} 25^{\mathrm{Hi}}$ varia enormemente (entre $2 \%$ e 60\%) de indivíduo para individuo, resultando numa grande variação na 
capacidades de hidrolise do ATP por Tregs de diferentes doadores (BORSELLINO et al., 2007). Apesar do grande número de doadores saudáveis avaliados ( $n=74$ ), as porcentagens de células $\mathrm{CD} 39+$ dentro das Tregs $\mathrm{CD} 4+\mathrm{CD} 25^{\mathrm{Hi}}$ não foram apresentadas graficamente ou de forma descritiva, sem uma porcentagem média e o desvio padrão associado.

Digno de nota, diferente de murinos, em humanos, somente os linfócitos T CD4 com alta expressão de CD25 apresentam capacidade supressora, enquanto que os linfócitos efetores e de memória expressam níveis intermediários de CD25. Aparentemente, em humanos, a expressão de CD39 estaria restrita a uma subpopulação de células Treg com características efetoras e de memória ( $\left.T_{R E M}\right)$, co-expressando CD45RO e CCR6, que atuariam em tecidos inflamados potencialmente removendo o sinal de estresse proveniente do ATP extra-celular (BORSELLINO et al., 2007; DEAGLIO et al., 2007; GORINI; LA SALA, 2008).

A ausência de uma estrita associação da expressão de CD39 com CD25 ou FoxP3 em humanos foi igualmente relatada por Dwyer e colaboradores, sendo que cerca de $70 \%$ dos linfócitos Treg CD4+CD25+CD127 $7^{10}$ expressariam FoxP3 e CD39 simultaneamente ( $n=3)$ (DWYER et al., 2010). Mediante estimulo e cultura in vitro, os linfócitos CD4+CD25+CD39+ não proliferam ou produzem citocinas, enquanto que as células T CD4+CD25+CD39- proliferaram e secretaram grandes quantidades de IL-2, IL-4 e IL-5, e menores quantidades de IL-10 e TNFa; indicando que estes linfócitos CD4+CD25+CD39+ teriam características de Tregs. Adicionalmente, mais de $80 \%$ das células $T$ CD4+CD25+CD39+ e todas CD4+CD25-CD39+ são CD45RO+, corroborando o fenótipo Treg de memória (DWYER et al., 2010).

Mandapathil e colaboradores descreveram que no sangue periférico de doadores saudáveis $(n=15)$, em média cerca de $80 \%$ dos linfócitos CD4+CD25 $5^{\text {hi }}$ expressam CD39 ou FOXP3, contra uma expressão destes marcadores de cerca de $20 \%$ e $50 \%$, respectivamente, na população CD4+CD25+. Ainda, dentre os linfócitos CD4+CD39+, em média quase $80 \%$ expressava FoxP3. Importantemente, os linfócitos CD4+CD39+ tiveram capacidade supressora equiparável aos linfócitos $\mathrm{CD} 4+\mathrm{CD} 25^{\mathrm{hi}}$; resultado que o 
fez sugerir a possibilidade de uso do marcador CD39 para a separação imunomagnética de linfócitos Treg (MANDAPATHIL et al., 2009).

Importantemente, também em contraste com murinos, Dwyer relatou que o marcador CD73 era praticamente ausente na superfície de linfócitos CD4+, sendo expresso em apenas cerca de 3\% destes, sem nenhuma co-expressão com CD39 ou CD25. Ainda, CD73 tampouco tem sua expressão induzida em células T naive CD4+CD25- após estimulação com IFNa ou com IFNy (DWYER et al., 2010).

Em linha, Schuler relatou que no sangue periférico de doadores saudáveis $(n=10)$, enquanto nos linfócitos CD4+CD39+, cerca de $50 \%$ das células seriam positivas para FoxP3; dentre as CD4+CD39-, apenas cerca de $5 \%$ seriam FoxP3+. Ainda, dentre as células CD39+CD25+, cerca de 90\% seriam FoxP3+, contra cerca de 5\% dentre as CD39+CD25- (SCHULER et al., 2011). Assim, a população de células CD4+CD39+ em humanos se subdividiria em células supressoras CD25+FOXP3+ (também negativas para CD127 e CD49d) e células CD25-FoxP3- (positivas para CD127 e CD49d) sem potencial supressor. Ainda, a ausência de expressão de CD73 na superfície das células CD4+CD39+ foi confirmada num segundo trabalho (SCHULER et al., 2012).

Apesar das células CD4+CD39+ no sangue periférico de humanos serem capazes de hidrolisar ATP, a capacidade de gerar adenosina de forma autônoma não havia sido demonstrada até então, tendo em vista a ausência de expressão de CD73 na superfície dos linfócitos (responsável pela conversão de AMP em adenosina). De fato, a ausência de expressão de CD73 na superfície das Tregs humanas circulantes, aparentemente as diferenciaria das murinas.

Importantemente, Mandapathil mostrou que no sangue periférico de humanos $(n=15)$, em média, cerca de $70 \%$ dos linfócitos Treg CD4+CD25 $5^{\text {hi }}$ expressam altos níveis de CD73 intracelularmente (contra cerca de 5\% expressando na superfície), enquanto que apenas cerca de $20 \%$ dos linfócitos T CD4+CD25- expressam CD73 intracelular e em níveis mais baixos (MANDAPATHIL; HILLDORFER; et al., 2010). Este achados revelaram que a localização de CD73 poderia corresponder a um mecanismo de regulação espécie-específico associado a diferenças, na sinalização purinergica, entre 
murinos e humanos. Neste trabalho, Mandapathil demonstrou que, mesmo sem expressar CD73 de superfície, os linfócitos Treg CD4+CD25 hi apresentavam uma maior capacidade de produzir adenosina que os linfócitos CD4+CD25-; sugerindo que os linfócitos liberariam CD73 em sua forma solúvel (sCD73) (RESTA; YAMASHITA; THOMPSON, 1998), como sugerido por outros (AIRAS et al., 1997; THOMSON et al., 1990).

Em contraste, um outro trabalho do mesmo grupo de Mandapathil relatou que CD73 estaria expresso em cerca de 70\% dos linfócitos, tanto na população CD39+CD25+ e CD39+CD25-, como nas populações CD4+CD39+ e CD4+CD39- (SCHULER et al., 2011). Não fica claro se estas diferenças poderiam se dever à inespecificidade da marcação em células permeabilizadas e estes resultados não foram discutidos pelo grupo em trabalhos posteriores.

Importantemente, como incialmente observado por Mandapathil e colaboradores (MANDAPATHIL; HILLDORFER; et al., 2010), trabalhos iniciais caracterizando CD73 em células humanas, sugerem que a ligação do próprio anticorpo anti-CD73 poderia causar a liberação de CD73 da membrana dos linfócitos, mas não de células endoteliais (que aparentemente os internalizariam). Este fenômeno de "shedding" dependeria da temperatura e da presença de $\mathrm{Ca} 2+$ e $\mathrm{Mg} 2+$ no meio, durante a incubação com os anticorpos, sendo minimizado a $4^{\circ} \mathrm{C}$ e na ausência dos ions. Ainda, clones de anticorpos reconhecendo diferentes epitopos teriam efeitos distintos. Este fenômeno estaria associado à perda completa de marcação em metade das células (AIRAS et al., 1997).

Em outro trabalho, Mandapathil demonstrou que linfócitos Treg induzidos in vitro, a partir de linfócitos CD4+CD25- isolados de sangue periférico, tem um aumento significativo na porcentagem de linfócitos positivos para FoxP3, CD73 intracelular e CD39 (dentro da população CD3+CD4+), de forma a produzir adenosina em maior quantidade. No entanto, estes linfócitos iTregs seriam observados apenas mediante complexos cocultivos simulando o microambiente tumoral; na presença de varias citocinas, APCs dendriticas e células tumorais, particularmente expressando ciclo-oxigenase 2 (COX2), a enzima responsável 
pela produção de prostaglandina E2 (PGE2) (MANDAPATHIL; SZCZEPANSKI; et al., 2010).

Digno de nota, apesar da instabilidade do marcador CD73 na superfície dos linfócitos do sangue periférico de humanos, sugerida por Mandapathil (MANDAPATHIL; HILLDORFER; et al., 2010), um trabalho posterior do mesmo grupo demonstrou que as iTregs, geradas in vitro pelo método de simulação do nicho tumoral a partir de uma população do sangue periférico CD4+CD25negativa para CD73 de superfície, passavam a expressar CD39 e CD73 de superfície numa porcentagem considerável das células, variando de 12 a mais de 40\% ( $n=5)$ (SCHULER et al., 2014). Ainda, o autor menciona que mediante ativação (utilizando beads anti-CD3/CD28) de nTreg isoladas do sangue de doadores saudáveis $(n=3)$, a porcentagem de células expressando CD73 na superfície passou de 5\% para 15\% (SCHULER et al., 2014). Adicionalmente, os linfócitos CD39+ poderiam produzir adenosina tanto pela coexpressão de CD73 na superfície da mesma célula, como pela complementação com CD73 ligado à membrana de outras células ou exosomos (SCHULER et al., 2014).

Como mencionado inicialmente, este trabalho derivou de achados anteriores de nosso grupo, obtidos ao investigar os mecanismos envolvidos na supressão da proliferação de linfócitos T ativados pelas MSCs. De acordo com esse estudo, o aumento dos níveis de adenosina seriam resultado do aumento de MSCs expressando CD39, em adição ao marcador CD73 tipicamente expresso na superfície das MSCs (aumentando a porcentagem de MSCs CD39+CD73+ de cerca de 10\% para 30\%), assim como de linfócitos Treg CD4+CD25 $5^{\text {hi }}$ induzidos co-expressando CD39 e CD73 (SALDANHA-ARAUJO et al., 2011). Mais especificamente, mediante ativação (também por bead antiCD2/CD3/CD28) de linfócitos CD3+ isolados do sangue periférico e cultivo por cinco dias, esse trabalho anterior observou que somente mediante cocultivo com CTMs, o CD73 era expresso na superfície do linfócitos, com cerca $8 \%$ de linfócitos CD39+CD73+ dentre os CD4+CD25 ${ }^{\mathrm{hi}}$.

Os achados do presente trabalho são de extrema relevância, tendo em vista o fato de termos demonstrado pela primeira vez que a simples ativação (com bead anti-CD2/CD3/CD28) de linfócitos $T$ naive CD4+CD45RA+ de 
sangue de cordão umbilical de humanos, seguida da cultura com IL-2, é capaz de induzir a geração de uma população de linfócitos expressando CD39 e CD73 de superfície em cerca de $12 \%$ da população CD4+CD25+. Ainda, mediante adição de TGF-beta e atRA, quase $50 \%$ dos linfócitos CD4+CD25+ expressam CD73 em sua superfície, resultando em mais de $30 \%$ de linfócitos duplo-positivos CD39+CD73+. Estes dados se tornam ainda mais relevantes, tendo em vista a extensa caracterização (feita anteriormente por nosso grupo) dos linfócitos iTreg gerados nestas mesmas condições. Mais especificamente, sob estas mesmas condições, linfócitos iTreg CD4+CD25 $5^{\text {hi } C D 127-F O X P 3 ~} 3^{\text {hi }}$ altamente supressivos são gerados, com mais de 60\% dos linfócitos CD4+CD25+ expressando FoxP3 (SCHIAVINATO et al., 2017).

Portanto, nossos resultados atuais indicam que a maior atividade supressiva dos linfócitos iTregs gerados nestas condições descritas anteriormente, podem ser em parte devidas à expressão concomitante de ambas emzimas responsáveis pela hidrolise do ATP em adenosina.

Importantemente, foi demonstrado recentemente que Tregs CD39 ${ }^{\text {hi }}$ apresentam maior estabilidade na expressão de FoxP3 e de sua função imunomodulatória, no contexto de ambientes inflamatórios, tanto in vitro como in vivo (GU et al., 2017). Em particular, isto estaria associado à menor expressão de IL-1ßR e IL-6R nas Tregs $C D 39^{\text {hi }}$ e a consequente redução na ativação dos fatores de transcrição downstream STAT1 e STAT3 inibiriam a trans-diferenciação dos mesmos em linfócitos Th1 ou Th17. Digno de nota, as iTregs geradas por nosso grupo (na presença de TGF-beta e atRA) apresentam uma inibição das vias IL-6/JAK/STAT e AKT-mTOR (SCHIAVINATO et al., 2017).

Em adição aos achados mencionados, nossa hipótese inicial sugeria que a sinalização da adenosina poderia ser parcialmente responsável pela geração de linfócitos CD4+CD25+CD39+CD73+ nos co-cultivos com CTMs (SALDANHA-ARAUJO et al., 2011). Mais especificamente, sugerimos que os receptores $A 2 a$ e $A 2 b$ poderiam estar envolvidos neste contexto, uma vez que ambos promovem o acumulo de cAMP via ativação da adenylyl cyclase (THIEL et al., 2003) inibindo a via via PI3K-AKT-mTOR downstream ao TCR (HASKO 
et al., 2008; XIE et al., 2011); cuja modulação sabidamente contribui para a geração de linfócitos Treg (HAXHINASTO et al., 2008; SAUER et al., 2008).

Tendo em vista o importante papel da adenosina na imunomodulação ocorrendo em tecidos periféricos inflamados (SITKOVSKY, M.; LUKASHEV, 2005) e a importância da geração de pTregs neste contexto (YADAV et al., 2013), outros grupos investigaram a mesma hipótese, de que a adenosina poderia modular o processo de indução de Tregs. No entanto, enquanto dois trabalhos indicavam que os receptores ADORA2A estariam envolvidos neste processo (OHTA et al., 2012; ZAREK et al., 2008), outros dois indicavam a participação de ADORA2B (EHRENTRAUT et al., 2012; NAKATSUKASA et al., 2011) e ADORA1 (NAKATSUKASA et al., 2011).

Como destacado por nós, o uso de concentrações inadequadas de diferentes fármacos (agonistas e antagonistas) poderia explicar, ao menos em parte, os resultados divergentes encontrados nestes estudos.

O estudo da sinalização de receptores com base no uso de agonistas e antagonistas farmacológicos encontram várias dificuldades, tendo em vista as limitações relacionadas à falta de drogas realmente específicas, bem como uma falta de parâmetros para se estabelecer as concentrações em que as mesmas teriam algum efeito funcional, em um determinado contexto biológico.

A grande maioria das drogas agonistas ou antagonistas dos receptores de adenosina (incluindo as utilizadas em nosso estudo, e nos mencionados acima) atuam competindo pelo sítio de ligação da adenosina. A especificidade de uma determinada droga por determinado receptor depende em parte da afinidade de interação entre a droga e o receptor alvo, de forma que numa determinada concentração os demais receptores não se liguem a esta droga. Neste sentido, a constante inibitória (Ki) de uma droga (agonista ou antagonista) corresponde à concentração em que $50 \%$ dela se encontraria ligada ao seu alvo (na ausência de um ligante competidor) (CHENG; PRUSOFF, 1973). Quanto menor o Ki, maior a afinidade de ligação da droga pelo receptor. Quanto maior for o Ki desta droga para os outros receptores, mais específica ela é. Portanto, o uso de concentrações elevadas de uma droga pode levar à ativação ou inibição inespecífica de outros receptores. 
Outro ponto que dificulta ainda mais o uso de drogas para estudos funcionais, é o fato dos valores de Ki de uma droga não estarem diretamente associados com a sua potencia específica (i.e. efeitos funcionais biológicos) (KLOTZ et al., 1998; NEUBIG et al., 2003). Diferente da afinidade de interação física do ligante com seu receptor (definida pelo Ki), a atividade biológica de um ligante sobre seu receptor é medida com base em ensaios funcionais que avaliam algum efeito bioquímico ou biológico, fornecendo um EC50, concentração onde se observa $50 \%$ da atividade máxima avaliada; assim, uma droga é considerada mais potente, quando seu receptor alvo tem uma maior sensibilidade a concentrações baixas da droga (menor EC50) (CHENG; PRUSOFF, 1973; KLOTZ et al., 1998; NEUBIG et al., 2003).

Como exemplo da diferença entre Ki e EC50, a própria adenosina apresenta diferenças consideráveis, neste sentido. Quanto à afinidade, enquanto os receptores A1 e A2a são receptores de alta-afinidade, se ligando a baixas concentrações de adenosina ( $\mathrm{Ki}$ na faixa de $[\mathrm{pM}]$ a $[\mathrm{nM}]$ ) ou médias ([nM], respectivamente); os receptores $A 2 b$ e $A 3$ tem baixa afinidade pela adenosina, se ligando a ela apenas em altas concentrações (na faixa [uM]), usualmente associadas com condições patogênicas (CRONSTEIN; SITKOVSKY, 2017). Por outro lado, com base em estudos avaliando o efeito da adenosina na produção de AMPc intracelular, os receptores $A 1$ e $A 3$ teriam uma maior sensibilidade à adenosina (EC50 entre 0,2-0,5 $\mu \mathrm{M}$ ), enquanto o receptor $A 2 A$ teria uma sensibilidade um pouco menor (EC50 0,6-0,9 $\mu \mathrm{M}$ ); o receptor A2B teria uma sensibilidade muito menor do que todos os outros subtipos de receptores (EC50 entre 16 e $64 \mu \mathrm{M})$ (JUNGER, 2011). Assim, enquanto os Kis dos receptores de adenosina seguem a seguinte relação de afinidade: $A 1>A 2 a>A 2 b=A 3$; a potência da adenosina (EC50 quanto à produção de $A M P C)$ nos diferentes receptores, segue a seguinte relação: $A 1=A 3>A 2 a>A 2 b$.

A exemplo da importância da ação da adenosina em função de diferentes concentrações; mediante condições inflamatórias nos tecidos, os neutrófilos tem sua função regulada pela sensibilidade de seus receptores à adenosina presente no local. Em baixas concentrações, a adenosina atuaria sobre os neutrófilos através dos receptores $A 1$ e A3 promovendo quimiotaxia e fagocitose; enquanto que em concentrações mais altas, a adenosina atuaria nos receptores de baixa 
afinidade $A 2 A$ e $A 2 B$, inibindo o tráfico de neutrófilos e suas funções efetoras, como produção de mediadores inflamatórios e liberação de grânulos (BARLETTA et al., 2012). Estas respostas dependeriam, entre outros fatores, do tipo e da quantidade de receptores expressos nas células, assim como, da posição das células no tecido inflamado; bem como da dinâmica de produção e eliminação da adenosina (SITKOVSKY, M. V.; OHTA, 2005).

Apesar desta variáveis, o Ki é um valor absoluto que não varia conforme o tipo de ensaio funcional, sendo uma boa referência para guiar o planejamento de estudos (KLOTZ et al., 1998; NEUBIG et al., 2003), de forma que eles foram utilizados para guiar o planejamento de nossos experimentos, como regra (Tabela 1).

Com base nas considerações acima, uma análise minuciosa dos trabalhos publicados, que investigaram o papel de diferentes receptores na geração de Tregs, acabou por nos alertar quanto a possíveis interpretações errôneas, derivadas de problemas ligados à inespecificidade das drogas, nas concentrações utilizadas.

Zarek e colaboradores, em 2008 demonstraram que a estimulação de TCR em células $\mathrm{T} \mathrm{CD4}^{+}$de camundongos juntamente com 0 uso de um agonista preferencial do receptor A2a (CGS21680) levava à diminuição da expressão de IL-6 e aumento da expressão de TGF- $\beta$, induzindo a geração de células T regulatórias FoxP3 ${ }^{+}$(ZAREK et al., 2008); no entanto, a concentração do agonista utilizada em seu trabalho (1uM) também seria suficiente para estimular os receptores $\mathrm{A} 1, \mathrm{~A} 2 \mathrm{a}$ e $\mathrm{A} 3$ ( $\mathrm{Ki}=289,27$ e 67nM, respectivamente), prejudicando suas conclusões acerca do papel específico de A2a na geração de células Treg.

Por outro lado, Nakatsukasa et. al. sugeriu que tanto os receptores A1 e $A 2 b$ estariam envolvidos na diferenciação de Tregs em murinos, uma vez que antagonistas de ambos receptores suprimiram a expressão de Foxp3 e a produção de IL-10; porem, somente o antagonista de A1 suprimiu a ativação de células T efetoras (NAKATSUKASA et al., 2011). Também neste estudo, o inibidor de A1 foi utilizado a 10uM, inibindo todos os receptores P1 (Kis entre 
187 e 2300nM), ao invés de inibir somente $A 1(\mathrm{Ki}=0,7 \mathrm{nM})$. Desta forma, dificultando as conclusões acerca do papel do receptor A1.

Estudos posteriores, também em camundongos, demonstraram que a ativação de receptores A2b com agonistas específicos (Bay 60-6583 a 4 nM; Ki = $3 \mathrm{nM}$ para $\mathrm{A} 2 \mathrm{~B}$ e $>10000 \mathrm{nM}$ para os demais receptores) ou não (NECA a 10 uM) levaram ao aumento da produção de células $T$ regulatórias (EHRENTRAUT et al., 2012). Neste último estudo, o uso de camundongos selvagens ou homozigotos knockout para $\mathrm{A} 2 \mathrm{~B}$, confirmou o papel deste receptor na geração de Tregs tanto in vitro como in vivo, apesar de linfócitos Treg ainda serem observados.

Em outro trabalho, Ohta e colaboradores relataram que, em culturas mistas de linfócitos murinos, ocorre um aumento de células Treg FoxP3+ funcionais após o estímulo do receptor A2a (com CGS e com NECA). Entretanto, em seu trabalho foi utilizado o agonista CGS21680 a $1 \mu \mathrm{M}$ (1000nM), concentração suficiente para estimular os demais receptores $A 1$, A2a e A3. ( $K i=289,27$ e 67nM, respectivamente). Ainda, a inibição do efeito de CGS (e NECA) observada com o uso do antagonista ZM, também não suporta a conclusão do autor acerca do papel especifico de A2a, uma vez que a droga ZM foi utilizada a $1 \mu \mathrm{M}$, concentração suficiente para inibir todos os quatro receptores de adenosina (Ki $\leq 774 \mathrm{nM}$ ) (OHTA et al., 2012). Adicionalmente, neste mesmo ensaio, Ohta relatou que NECA e CGS levavam a um aumento na população de células $C D 4+C D 39+C D 73+$, oque ele atribuiu à sinalização de A2a, no entanto, nos resultados apresentados, ele omite as condições de tratamento que combinam os agonistas NECA e CGS com o inibidor ZM (ver discussão junto aos resultados da avaliação inicial). Interessantemente, em seu trabalho Ohta apresenta uma avaliação adicional mostrando que os agonistas NECA e CGS induzem a expressão dos marcadores CD39 e CD73.

Como um todo, estas informações levantaram a possibilidade de que os efeitos supostamente atribuídos à $\mathrm{A} 2 \mathrm{a}$, poderiam derivar de efeitos não específicos sobre os receptores A1 ou A3. Importantemente, todos os trabalhos mencionados acima, foram feitos em camundongos. Assim, além de não estar claro qual dos diferentes receptores de adenosina teria um papel na regulação 
do processo de geração de Tregs em camundongos, estes achados podem não se aplicar a humanos. Em vista da possível interpretação equivocada, com base no uso de concentrações inespecificidade das drogas, decidimos reavaliar esta questão de forma mais detalhada, e em linha com os valores de $\mathrm{Ki}$ conhecidos.

Assim, linfócitos Naive CD4+CD25-RA+ isolados foram ativados e cultivados apenas na presença de IL-2, ou com a adição de diferentes combinações de agonistas e antagonistas (Figura).
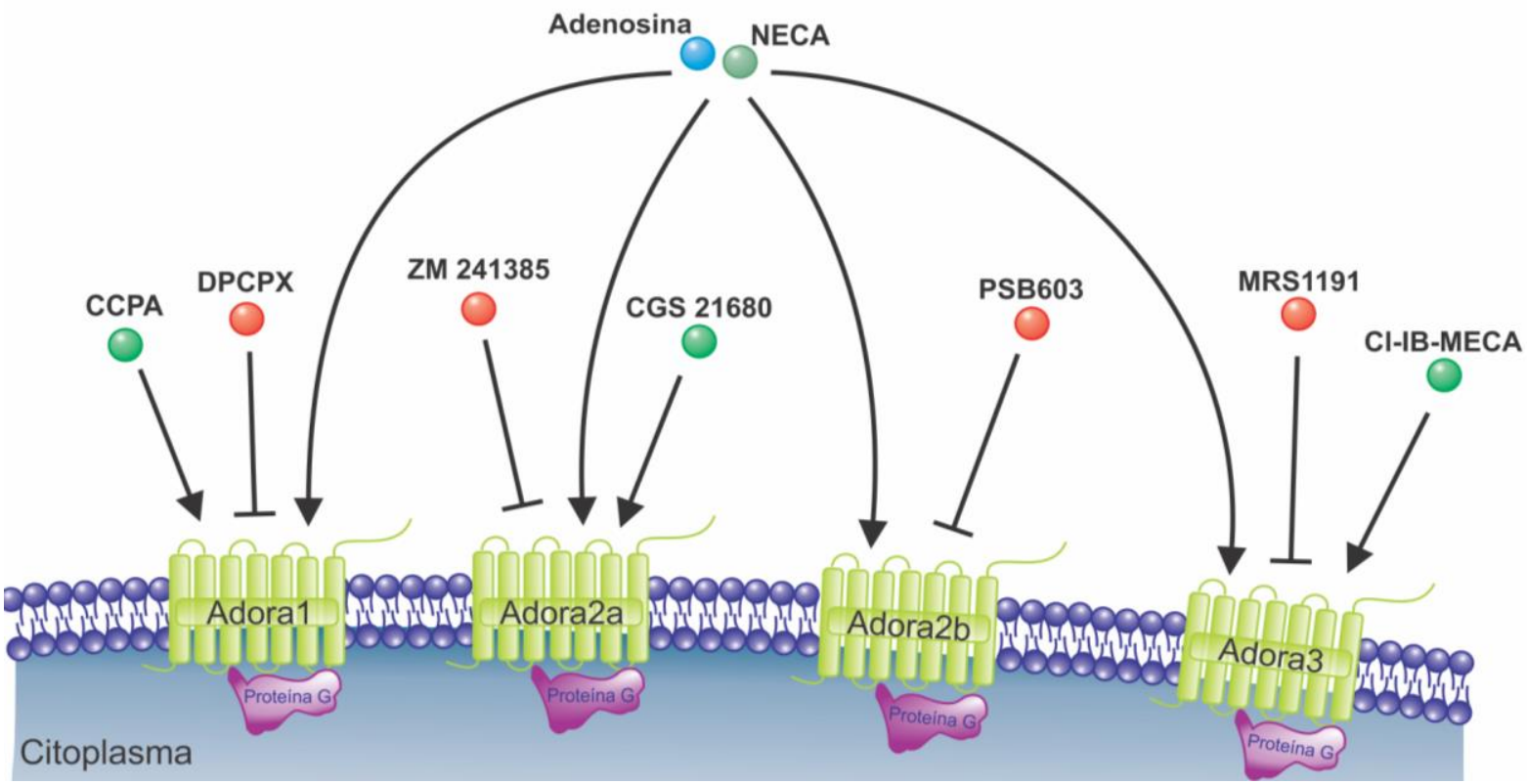

Figura 6. Os quatro tipos de receptores de adenosina: receptores A1, A2a, A2b e A3. Esquema representativo da ação da molécula de adenosina (em azul), que é um ligante generalista e dos papéis de ativação dos receptores por drogas agonistas (em verde) e da inibição dos receptores por drogas antagonistas (em vermelho).

O uso do análogo de adenosina NECA, agonista genérico dos receptores, levou a um aumento nas porcentagens de linfócitos expressando CD39 e CD73, tanto nas concentrações de $0,1 \mathrm{uM}$ como de $5 \mathrm{uM}$ (muito superior ao $\mathrm{Ki}$ de todos os receptores), indicando que de maneira geral a sinalização sobre todos os receptores de adenosina teria como efeito líquido a geração de CD4+CD25+CD39+CD73+. Por outro lado, o antagonista ZM, também levou a um aumento nas porcentagens de linfócitos expressando CD39 e CD73, tanto nas concentrações de 0,1uM como de 5uM (muito superior ao Ki de todos os 
receptores). Estes resultados exemplificam a complexa regulação destes receptores, associada à integração entre os efeitos opostos dos diferentes receptores promovendo ativação ou inibição da adenilil ciclase; de forma que o resultado líquido depende dos níveis de expressão dos diferentes receptores na superfície das células.

Surpreendentemente, nossos resultados revelaram que o agonismo do receptor A1 de adenosina durante o cultivo dos linfócitos $T$ naive ativados (na presença de IL-2) leva a um aumento significativo na porcentagem de linfócitos coexpresssando CD39 e CD73; de forma que a simples adição do agonista específico CCPA resulta em porcentagens próximas às condições de geração de iTregs baseada no uso de TGF-beta e atRA; condições estabelecidas de geração de iTregs clássicas CD4+CD25hiFoxP3 (SCHIAVINATO et al., 2017). Importantemente, os linfócitos gerados na condição na presença do agonista do receptor de adenosina $A 1$, produzem níveis mais altos de IL-10 e de adenosina. Este resultado, estaria em linha como os achados de Nakatsukasa et. al., uma vez que o antagonista do receptore A1 suprimiu a expressão de Foxp3 e a produção de IL-10 (NAKATSUKASA et al., 2011).

Outro achado interessante resultou da avaliação feita nos níveis de expressão gênica de ADA, CD39, CD73 e de alguns receptores de adenosina em linfócitos $T$ naive recém-isolados de sangue de cordão umbilical e após ativação apenas na presença de IL-2, ou com a adição de TGF-beta e atRA. Enquanto, os níveis dos transcritos de ADORA2A, ADORA2B, ADA e CD39 foram reduzidos mediante ativação dos linfócitos (em comparação às células T naive), os níveis de ADORA1 e CD73 foram aumentados.

Em murinos, enquanto linfócitos $T$ expressam principalmente os receptores A2a e A2b (THIEL et al., 2003), os receptores A1 e A3 também são expressos tanto em células $T$ naive quanto em células $T$ regulatórias (EHRENTRAUT et al., 2012). No entanto, os papeis destes receptores na geração de Tregs humanas não são conhecidos (CRONSTEIN; SITKOVSKY, 2017). A indução transcricional de CD73 identificada por nós nos linfócitos ativados, esta em linha com um aumento de expressão desta proteína, seja para ocupar a membrana, seja para ser secretado. Por sua vez, a indução de 
ADORA1 poderia indicar um feedback positivo, levando à sensibilização dos linfócitos frente aos sinais mediados por este receptor.

Tendo em vista, nossa hipótese inicial, os achados de que o receptor A1 teriam um efeito positivo sobre a geração de Tregs, pode parecer contraditório a princípio, uma vez que este receptor predominantemente inibe a atividade da adenylyl cyclase, levando consequentemente à redução de AMP cíclico (cAMP) intracelular e uma maior ativação dos linfócitos (JUNGER, 2011; THIEL et al., 2003).

No entanto, a geração de linfócitos Treg resulta do equilíbrio entre a ativação do linfócito via TCR e da modulação de sua intensidade. De fato, como já mencionado, a diferenciação em Treg no timo ocorreria pelo processo de "seleção agonista", quando o TCR apresenta uma afinidade intermediária pelos auto-antígenos (ou TRAs) complexados ao MHC de classe II (apresentados pelas mTECs da na região medular); ou seja, nem demasiadamente forte para levar à deleção clonal nem demasiadamente fraca levando à geração de linfócitos $T$ naive efetores (HOGQUIST; JAMESON, 2014; HSIEH et al., 2012; JORDAN et al., 2001; MORAN et al., 2011). Portanto, apesar da inibição da via PI3K-AKT-mTOR em células $T$ ativadas tem um papel importante na indução de Foxp3 e na geração de linfócitos Treg (HAXHINASTO et al., 2008; SAUER et al., 2008), esta é uma via com importante papel na proliferação e sobrevivência de células $T$ efetores (BATTAGLIA et al., 2006). Nosso resultados estão mais uma vez, em linha com os achados de Nakatsukasa, que demonstrou que o antagonista de A1 suprime a ativação de células T efetoras, prejudicando a geração de Tregs (NAKATSUKASA et al., 2011).

Digno de nota, a adenosina não é o único nucleosideo purínico com ação imunomodulatória. De fato, o próprio ATP pode mediar uma potente ação antiinflamatória de forma direta, pela sinalização sobre seu receptor $P 2 Y_{11}$, o único receptor purinergico P2 acoplado à ativação de adenilil ciclase e produção de cAMP intracelular; expresso em células dendríticas, macrófagos, linfócitos T e NK de humanos, mas não as de murinos. Isto sugere que o papel da hidrolise do ATP 
extracelular em adenosina pode ter implicações fisiológicas mais complexas do que o postulado (GORINI; LA SALA, 2008).

Ainda, o AMP produzido pela hidrolize do ATP (mediada por CD39) é um agonista do receptor A1R tão potente quanto a adenosina, sugerindo que alguns dos efeitos fisiológicos mediados por este receptor (incluindo a inibição da adenilil ciclase e redução de cAMP intracelular) podem ser diretamente causados pelo AMP, e não indiretamente pela adenosina (produzida pela hidrolise do AMP, mediada por CD73) (RITTINER et al., 2012). Ainda, AMP também pode ativar o receptor A2A, de forma a modular células do sistema imune (PANTHER et al., 2012).

Ainda, os linfócitos nTreg CD4+CD25 hi circulantes no sangue tem baixa expressão de ADA e de sua proteína ancoradoura CD26 na superfície, sendo incapazes de metabolizar adenosina em inosina, enquanto células T efetoras convencionais (Teff) expressam ambas proteínas; sugerido que a ausência de CD26 poderia servir para identificar Tregs em humanos (MANDAPATHIL; HILLDORFER; et al., 2010). No sistema imune, o CD26 tem outras funções, como promover a ativação de células $T$, bem como interações de células $T$ com células apresentadoras de antígeno (DONG et al., 1996).

O papel de CD39 na superfície dos linfócitos pode não estar associado somente a um papel supressor. Indícios apontam que a subpopulação CD4+CD39+CD25FoxP3- seria composta por células de memória Th1, Th2 e Th17 pro-inflamatórias, podendo contribuir para a rejeição de alo-transplantes (ZHOU, Q. et al., 2009). Por outro lado, células Th17 de murinos induzidas por TGF-beta e IL-6 expressam CD39 e CD73, produzem adenosina e são imunossupressoras; enquanto que aquelas geradas apenas na presença de IL-1beta, IL-6 e IL-23 não o são (CHALMIN et al., 2012; MARTIN; APETOH; GHIRINGHELLI, 2012). A indução transcricional dos genes Entpd1 (CD39) e Nt5e (CD73) nas células TH17+ resultariam da ativação do fator de transcrição Stat3 (mediada por IL-6) e da inibição de Gfi-1 (mediada pelo TGF-beta) (CHALMIN et al., 2012). 
7- Conclusões 
Quanto à expressão de CD39 em células mesenquimais isoladas, observamos que a estimulação com citoquinas, agonistas e antagonistas próinflamatórios de receptores de adenosina não resultou em alterações na expressão do receptor de membrana. A expressão citosólica CD39 significativa também foi observada na CTM por permeabilização. A incubação de CTM com sobrenadante de meio de cultura condicionado por linfócitos $T$ ativados induziu alta expressão de ADORA2A. Quando as células foram observadas em coculturas, CTMs e linfócitos T mostraram um aumento significativo na expressão de CD39 e CD73 em regiões de contato entre CTM e CD3 +. Nossos resultados indicam que esse aumento na expressão de CD39 / CD73 durante a interação de CTM e CD3 + pode estar relacionado às propriedades imunomoduladoras das CTMs. Esses dados abrem novas alternativas para o estudo da imunomodulação mediada por CTM e sua aplicação no desenvolvimento de novos tratamentos para GVHD e outras doenças inflamatórias. 
CAPITULO II:

\title{
CD39 EM CÉLULAS-TRONCO ESTROMAIS
} MESENQUIMAIS E LINFÓCITOS T CD3+

\author{
ATIVADOS
}




\section{RESUMO}

DEFREITAS, H. T.. 2017. 174f. Tese (Doutorado) - Faculdade de Medicina de Ribeirão Preto, Universidade de São Paulo, São Paulo, 2017.

Nosso grupo recentemente identificou de forma inédita, que a produção de adenosina mediada pelas ectonucleotidases CD39 e CD73 é um importante mecanismo imunomodulador das células estromais mesenquimais (CEM) humanas de medula óssea, suprimindo a proliferação de células T $C D 4^{+}$ ativadas. O CD39 hidrolisa o ATP (adenosina trifosfato) extracelular e o ADP em AMP, enquanto, o CD73 converte o AMP em adenosina. Especificamente, mediante cocultivo com células $\mathrm{T} \mathrm{CD}^{+}$ativadas, as CEM apresentavam maior expressão de CD39 em sua superfície, produzindo mais adenosina. Embora CD73 seja um dos marcadores fenotípicos clássicos de CEM, a expressão da molécula CD39 nas CEM não está totalmente estabelecida, não estando claro se as CEM expressariam CD39 intracelular (exteriorizando-o mediante algum estímulo), ou se ele seria adquirido por transferência de outras células (como linfócitos). Com o intuito de responder esta questão, CEM foram estimuladas com citocinas inflamatórias (IL-6, IL-1B, INF-g e TNFa) ou com meio condicionado por linfócitos $\mathrm{T} \mathrm{CD}^{+}$ativados (isolados de sangue periférico) ou com drogas agonistas e antagonistas para receptores de adenosina, e a expressão extra e intra-celular de CD39 e CD73 foi avaliada por citometria de fluxo. Adicionalmente, a expressão de CD39 e CD73 foi avaliada em CEM isoladas ou em co-culturas com linfócitos $\mathrm{T} \mathrm{CD3}^{+}$humanos ativados por microscopia de fluorescência quantitativa. Para isso, a imagens adquiridas por um sistema automatizado de High Content Analysis - HCA (ImageXpress, Mol. Dev.) foram analisadas com o software CellProfiller. Nenhum estimulo inflamatório ou modulação dos diferentes receptores de adenosina, alterou a expressão ou localização de CD39 ou CD73 nas CEM; no entanto, diferente do observado para CD73, as CEM praticamente não apresentaram marcação extracelular de CD39, porem, mais de 70\% das CEM expressam CD39 intracelular. Ao avaliarmos os cocultivos por HCA, observamos um aumento significativo na intensidade de CD39 e CD73 nas regiões das CEM próximas aos pontos de interação com os linfócitos CD3 ativados, quando comparadas às zonas sem contato. Tendo em vista a expressão intracelular de CD39, e a ausência de exteriorização com os estímulos utilizados, e ainda, considerando a localização preferencial de CD39 e CD73 nas regiões de contato com os linfócitos ativados, nossos resultados podem indicar um processo de imunomodulação localizado, favorecendo a produção de adenosina na região imediatamente justaposta aos linfócitos, de forma a maximizar seu efeito antes de sua rápida degradação. Nossos resultados inéditos esclarecem os mecanismos pelos quais as CEM, mediante interação com linfócitos ativados, podem localizar e maximizar a produção e os efeitos imunossupressores da adenosina. Estes resultados contribuem para o entendimento dos mecanismos imunomodulatórios desempenhados pelas CEM, tanto no contexto da manutenção da homeostase nos tecidos periféricos, bem como em sua eventual aplicação

terapêutica.

Palavras-chave: ectonucleotidades; células estromais mesenquimais; adenosina. 


\section{ABSTRACT}

Our group recently identified that adenosine production mediated by CD39 and CD73 ectonucleotidases is an important immunomodulatory mechanism of human bone marrow mesenchymal stromal cells (CEM), suppressing the proliferation of activated CD4 + T cells. CD39 hydrolyzes extracellular ATP (adenosine triphosphate) and ADP in AMP, while CD73 converts AMP to adenosine. Specifically, by cocultivation with activated CD4 + T cells, the CEM presented higher expression of CD39 on its surface, producing more adenosine. Although CD73 is one of the classical phenotypic markers of CEM, the expression of the CD39 molecule in CEM is not fully established, it is unclear whether CEM would express intracellular CD39 (externalizing it by some stimulus), or whether it would be acquired by transfer of other cells (such as lymphocytes). In order to answer this question, CEM were stimulated with inflammatory cytokines (IL-6, IL-1B, INF-g and TNFa) or with activated CD3 + T lymphocytes (peripheral blood isolates) or with agonist and antagonist drugs for adenosine receptors, and extra and intracellular expression of CD39 and CD73 was assessed by flow cytometry. In addition, expression of CD39 and CD73 was evaluated in isolated CEM or in co-cultures with human CD3 + T lymphocytes activated by quantitative fluorescence microscopy. For this, the images acquired by an automated system of High Content Analysis - HCA (ImageXpress, Mol. Dev.) Were analyzed with the CellProfiller software. No inflammatory stimulus or modulation of the different adenosine receptors altered the expression or localization of CD39 or CD73 in CEM; however, different from that observed for CD73, EMFs showed practically no extracellular labeling of CD39, but more than 70\% of EMCs expressed intracellular CD39. When we evaluated the co-cultures by HCA, we observed a significant increase in the intensity of CD39 and CD73 in the EMF regions near the points of interaction with the activated CD3 lymphocytes when compared to the non-contact zones. In view of the intracellular expression of CD39, and the absence of exteriorization with the stimuli used, and also, considering the preferential location of CD39 and CD73 in the regions of contact with the activated lymphocytes, our results may indicate a localized immunomodulation process favoring the production of adenosine in the region immediately juxtaposed to the lymphocytes, in order to maximize its effect before its rapid degradation. Our unpublished results clarify the mechanisms by which EMF, through interaction with activated lymphocytes, can locate and maximize the production and immunosuppressive effects of adenosine. These results contribute to the understanding of the immunomodulatory mechanisms performed by EMF, both in the context of maintaining homeostasis in the peripheral tissues, as well as in its eventual therapeutic application.

Keywords: ectonucleotidases; mesenchymal stromal cells; adenosine. 
8- INTRODUÇÃO 
Como já mencionado, ao realizar um estudo transcriptômico do efeito das MSCs sobre linfócitos $T$ ativados com partículas magnéticas ligadas a anticorpos anti-CD2/CD3/CD28 (de forma a mimetizar células apresentadoras de antígenos), nosso grupo identificou que a expressão da enzima adenosina deaminase (ADA) estava reduzida nos linfócitos cocultivados com MSCs, enquanto que a do receptor de adenosina ADORA2A estava aumentada (em relação a linfócitos não co-cultivados) (SALDANHA-ARAUJO et al., 2011).

Os níveis de adenosina são controlados pela enzima $A D A$, que a converte em inosina (FRANCO et al., 1998). A ADA pode se ligar ao marcador de ativação CD26 na superfície externa da membrana celular, o que reduz a concentração local de adenosina e a sinalização mediada por seus receptores, permitindo que as células escapem do mecanismo de inibição mediado pela adenosina (DONG et al., 1996).

Interessantemente, os resultados do nosso grupo revelaram que a porcentagem de linfócitos $\mathrm{T}$ CD4+ expressando CD26 estava significativamente reduzida mediante co-cultivo com MSCs (de $80 \%$ para $60 \%$ ), e que esta porcentagem era significativamente maior em linfócitos Treg CD4+CD25 hi (acima de 90\%) (SALDANHA-ARAUJO et al., 2011).

Ainda, uma investigação detalhada revelou, mediante o co-cultivo, um aumento significativo na porcentagem de MSCs expressando CD39 (de 15\% para $30 \%$, todas correspondendo a células CD73+CD39+, uma vez que praticamente todas as MSCs expressam CD73), e de linfócitos Treg CD4+CD25 hi expressando CD73 (de 1\% para 17\%, correspondendo a cerca de $8 \%$ linfócitos Treg CD4+CD25 $\left.{ }^{\text {hi }} \mathrm{CD} 73+\mathrm{CD} 39+\right)$. Em linha, os co-cultivos apresentaram um aumento nos níveis de adenosina no meio, revelando um mecanismo inédito de imunomodulação mediada pelas MSCs sobre os linfócitos T ativados (SALDANHA-ARAUJO et al., 2011). Finalmente, o bloqueio farmacológico da sinalização via ADORA2A neste contexto, afetou significantemente a supressão da proliferação dos linfócitos $T$, indicando um efeito mediado por este receptor. 
Já bem descritas na literatura, as células do estroma mesenquimatosas são fortemente candidatas a terapias baseadas em células e reparações por seus atributos como: potencial de diferenciação e produzir altos níveis de fatores imunorreguladores, fatores de mobilização celular e fatores de crescimento e reparo tecidual por residentes células (NAJAR et al., 2018). O microambiente celular e o estado inflamatório desempenham papéis fundamentais na determinação do fenótipo MSC e seus efeitos sobre o sistema imunológico. Os MSC exibem uma plasticidade notável, exercendo fenótipos pro e antiinflamatórios dependendo desses estímulos ambientais (WATERMAN et al., 2010). Ao equilibrar este fenótipo ativador ou supressor, os MSCs podem ser críticos para a regulação do controle imunológico e reparo e regeneração de tecidos(NOWARSKI; JACKSON; FLAVELL, 2017).

Os marcadores de superfície participam efetivamente no mecanismo de imunossupressão exercido pelos MSCs (HADDAD; SALDANHA-ARAUJO, 2014). As ectonucleotidases CD39 e CD73 são os principais reguladores das concentrações extracelulares de ATP, pois degradam-se para a adenosina. Conforme verificado por nosso grupo, esses marcadores de superfície são regulados positivamente em locais inflamatórios e induzem a produção de adenosina, que, em sequência, contribui para a imunossupressão de células $T$. (SALDANHA-ARAUJO; PANEPUCCI, 2011) Os MSCs têm um fenótipo particular que permite sua identificação, bem como define suas funções biológicas, e também expressa CD73 abundante, e uma baixa porcentagem de MSCs também expressam CD39. Os MSCs também induzem a expressão de CD39 em certas populações de células $T$, resultando em concentrações aumentadas de adenosina em culturas de células T (SALDANHA-ARAUJO et al., 2011). Essas observações sugerem que células imunes e células estromais cooperam para restaurar o equilíbrio de ATP após infecção e lesão, e sugerem que os MSCs exigem a presença de células imunes específicas para atingir os efeitos imunossupressores máximos (KERKELA et al., 2016).

Em contraste com as observações de nosso grupo (Saldanha-Araujo, Ferreira et al., 2011), Kerkela, Laitinen et al. (2016) descreve uma falta ou baixa expressão CD39 em MSCs. Tal relatório pode ser devido ao epítopo de anticorpo usado ou devido ao projeto experimental. No entanto, buscamos 
elucidar no presente estudo se a expressão citoplasmática de CD39 em células mesenquimais poderia ser induzida por componentes inflamatórios ou sinalização adenosinérgica. Estes resultados podem contribuir para elucidar a forma como o processo ocorre.

\subsection{Células-tronco Estromais Mesenquimais}

As células estromais mesenquimais (CTM) constituem um subconjunto heterogêneo de células regenerativas estromais que pode ser colhido de vários tecidos adultos. Outros nomes descritivos para populações CTM na literatura incluem: mesenchymal stromal cells (células mesenquimais estromais), mesenchymal progenitor cells (células progenitoras mesenquimais), multipotent mesenchymal stromal cells (células estromais mesenquimais multipotentes), bone marrow stromal cells (células do estroma de medula óssea), bone marrow-derived CTM (CTM derivadas de medula óssea), multipotent stromal cells (células estromais multipotentes), mesenchymal precursor cells (células precursoras mesenquimais), skeletal stem cells (células-tronco esqueléticas), bem como células de sinalização medicinal.(SAMSONRAJ et al., 2017)

São células multipotentes capazes de se diferenciar em vários tipos de células especializadas, incluindo osteoblastos, condrócitos e adipócitos. Estudos recentes indicam que os CTM se assemelham a pericitos e emergem do estroma periférico, região em torno dos vasos sanguíneos, esclarecendo assim o seu vasto potencial regenerativo em tecidos adultos.(LV et al., 2014) Sua relativa facilidade de isolamento, combinada com suas capacidades para auto-renovação e multipotencialidade tornam as CTMs uma promissora opção para uma variedade de condições clínicas. A administração de CTM (por via intravenosa ou por injeção direta em tecido) não produziu resultados clínicos consistentes, visto que a sobrevivência das células injetadas no hospedeiro é curta. A melhora clínica observada em alguns casos levou às primeiras ideias alternativas como os seus efeitos tróficos.(SOBACCHI et al., 2017)

As células-tronco multipotentes mesenquimais do estroma podem ser isoladas de diferentes fontes, como medula óssea, músculos esqueléticos, polpa dentária, cordão umbilical, sangue periférico e tecido 
adiposo.(ANDREEVA et al., 2017) São componentes essenciais da homeostase tecidual, remodelação fisiológica e reparo pós dano. Atualmente, as CTMs são consideradas componente valioso da terapia celular e da medicina regenerativa principalmente devido à sua capacidade de produzir moléculas biologicamente ativas. Além dessas propriedades, os CTMs são capazes de modulação imunológica, que pode proporcionar a supressão da resposta imune do hospedeiro quando usado na configuração alogênica. (ENGLISH, 2013).

Para melhorar a definição das CTMs, a Sociedade Internacional de Terapia Celular (ISCT) designou como células multipotentes mesenquimais estromais àquelas células aderentes ao plástico em condições padrão de cultivo in vitro. O fenótipo de superfície da cultura de CTMs definidos pelo ISCT é negativo para os marcadores CD14 ou CD11b, CD45, CD34, CD79 ou CD19, e HLA-DR. E em geral, positivo para CD73, CD90 e CD105.(LV et al., 2014) No entanto, não há um único marcador que possa ser utilizado para distinguir CTMs a partir de todos os outros tipos celulares. Outro critério para designação como CTMs é a capacidade de se diferenciar em adipócitos, osteócitos e cartilagem com a adição de fatores de crescimento exógenos. Embora as CTMs possam se diferenciar em várias células maduras, a capacidade intrínseca de secretar citocinas e fatores de crescimento nos locais de lesão e tecidos inflamados contribui de forma significativa para a sua capacidade terapêutica. A produção desses fatores tróficos é definida pela sua localização, nicho e gravidade das lesões.

\subsection{Mecanismos de imunomodulação mediada por células estromais mesenquimais}

Foram recentemente propostos dois paradigmas que postulam que: CTMs têm funções que thes permitem reconhecer o seu microambiente e atuar em conformidade e que as CTMs se tornam polarizadas para um fenótipo próinflamatório ou um fenótipo imunossupressivo dependendo do TLR sinais recebidos (WATERMAN et al., 2010). Juntos, esses conceitos ajudam a 
resolver dados conflitantes mostrando que, em alguns casos, as CTMs aumentam a sobrevivência e função das células imunes e, em outras, inibem a inflamação e incentivam a reparação. A imunomodulação do CTM ocorre através de um processo de vários estágios envolvendo resposta de CTM à inflamação e possível migração para o local de lesão tecidual, licenciamento ou ativação de CTMs, promoção da depuração de patógenos, se necessário e modulação de inflamação(ENGLISH, 2013) (Figura X). Além dos mecanismos acima discutidos, CTMs também exercem uma série de efeitos dependentes de contato.(SALDANHA-ARAUJO et al., 2011) Expressão das moléculas de adesão são necessárias para a interação com células $T$, facilitando a supressão mediada por ON ou IDO. O envolvimento de ligantes do tipo FAS/FASL, ligantes de morte programadas, galectinas e pequenas moléculas como adenosina produzida por CD39 e CD73 também foram relatados na modulação dependente de contato para CTMs. (SAMSONRAJ et al., 2017)
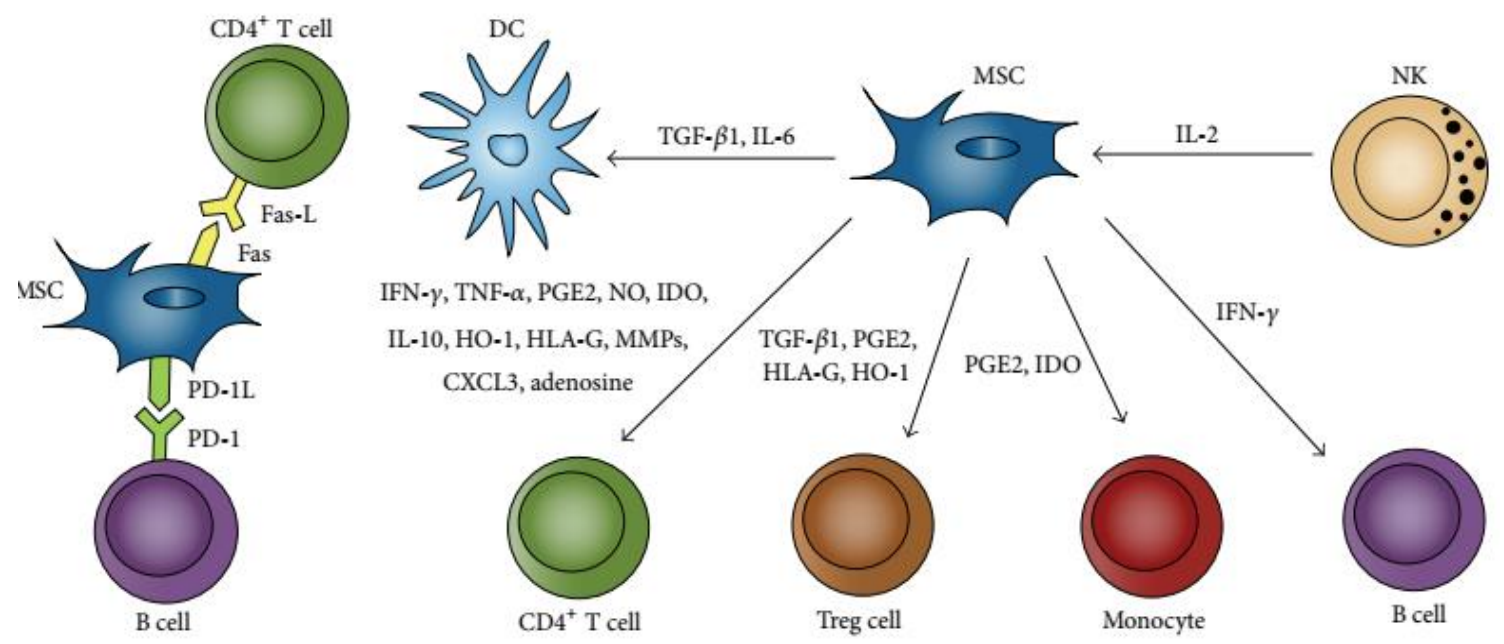

Figura 8.As CTMs exercem seu potencial de supressão imune por contato célulacélula e por secreção de moléculas reguladoras imunes. As CTMs podem inibir a proliferação e a função das células $T$, células $T$ natural killer (NKT), células $T$ reguladoras, células $B$ e células dendríticas (DCs). No entanto, os CTM secretam IL-6 e preservam a viabilidade dos neutrófilos através da inibição da apoptose. Vários fatores solúveis desempenham importantes papéis nos efeitos imunossupressores das CTMs, incluindo prostaglandina E2 (PGE2), TGF- $\beta 1$, indolamina 2,3-dioxigenase (IDO), óxido nítrico, fator de crescimento de hepatócitos (HGF), interleucina IL-6 e IL10. Adaptado de KOVACH et al. (2015)

\subsection{CD39 e CD73 em células estromais mesenquimais}

As ectonucleotidases CD39 e CD73 são as principais reguladoras das concentrações extracelulares de ATP, pois o degradam à adenosina. CTMs 
expressam CD73 abundante, e uma baixa porcentagem de CTMs também expressam CD39. Os CTMs também induzem a expressão de CD39 em certas populações de células $T$, resultando em concentrações aumentadas de adenosina em coculturas de células T (SALDANHA-ARAUJO et al., 2011). Essas observações sugerem que células imunes e células estromais cooperam para restaurar o equilíbrio de ATP após infecção e lesão, além de sugerir que os CTMs exigem a presença de células imunes específicas para alcançar efeitos imunossupressores máximos (KERKELA et al., 2016).

Em contraste com as observações do nosso grupo(SALDANHAARAUJO et al., 2011),KERKELA et al. (2016) descreve uma falta ou baixa expressão CD39 nas CTMs. Tal relato pode ser devido ao epítopo do anticorpo utilizado ou devido ao desenho experimental. Entretanto, buscamos elucidar no presente trabalho se a expressão citoplasmática de CD39 em mesenquimais poderia ser induzida por componentes inflamatórios ou sinalização adenosinérgica. Estes resultados podem contribuir para elucidar a forma como ocorre o processo de produção de adenosina pericelular fundamental imunomodulação. 
9- Objetivos 


\section{Geral}

Esse trabalho tem como objetivo avaliar a expressão e localização da ectonucleotidase CD39 em células-tronco estromais mesenquimais tratadas com citocinas pró inflamatórias, agonistas e antagonistas de receptores de adenosina ou meio condicionado por linfócitos T CD3+ ativados.

\section{Específicos}

Cultivar CTMs na presença de citocinas pró inflamatórias, combinações de agonistas/antagonistas de receptores de adenosina ou meio condicionado por linfócitos CD3+ ativados.

Avaliar imunofenotipicamente as células tratadas por citometria de fluxo;

Analisar funcionalmente a localização dos marcadores CD39, CD73 e do receptor A2a em co-cultivos de CTMs e linfócitos T Cd3+, em ensaios de High Content Analysis. 


\section{0- Hipótese}


Hipotetizamos que em células-tronco estromais mesenquimais a ectonucleotidase CD39 pode ser exposta na superfíce celular mediante estímulos extracelulares, como ambientes inflamatórios ou contato célula-célula com linfócitos ativados. 


\section{1- MATeriais E MÉtodos}




\section{Células-tronco mesenquimais}

As CTMs utilizadas neste projeto foram obtidas conforme descrito em trabalhos anteriores (PANEPUCCl et al., 2004) a partir de amostras de medula óssea de doadores com consentimento, após total esclarecimento, de acordo com protocolos aprovados pelo Comitê de Ética em Pesquisa do Hospital das Clínicas da USP de Ribeirão Preto, que estão inseridos no projeto: "Isolamento e Caracterização de Células Progenitoras Mesenquimais de Diferentes Tecidos." Processo HCRP no 4855/2004. Adicionalmente, todas as amostras de CTM utilizadas neste estudo foram previamente caracterizadas por técnicas de imunofenotipagem e colorações, sendo positivas para os marcadores CD73, CD90, CD105, CD106, CD166, CD29 e CD44 e negativas para CD45, CD14, CD31, CD34 e HLA DR, bem como capazes de se diferenciarem em adipócitos (coloração com "Sudan II"), osteócitos (coloração com "von kossa") e condrócitos (imunocoloração com antígeno tipo II).

\section{Cultura celular}

Culturas de CTM foram realizadas em garrafas de cultura celular de 75 $\mathrm{cm} 2$, contendo $10 \mathrm{~mL}$ de meio de cultura composto por meio alfa-mínimo essencial (alpha-MEM, Invitrogen; Carlsbad, CA, EUA), suplementado com 50 $\mathrm{U} / \mathrm{mL}$ de penicilina e $50 \square \mathrm{g} / \mathrm{mL}$ streptomicina e $15 \%$ de SBF, sendo dispostas em uma estufa de $\mathrm{CO} 2$ a $37^{\circ} \mathrm{C}$. A cada dois dias, houve substituição de $50 \%$ do meio de cultura até que a confluência de $80 \%$ fosse atingida, havendo remoção do meio de cultura e adição de $5 \mathrm{~mL}$ de solução de tripsina a $1 \mathrm{X}$ em água destilada, por 5 minutos, para que as células aderentes atingissem 0 estado de suspensão. Após este período, $15 \mathrm{~mL}$ de meio de cultura foi adicionado e a suspensão celular foi então submetida a centrifugação a 1.500 rpm por 10 minutos, havendo o descarte do sobrenadante e suspensão do pellet celular em meio de cultura. Após a quantificação das células a partir da contagem em câmara de Neubauer, as células foram cultivadas novamente em 
garrafas de cultura celular com meio de cultura, criopreservadas em meio de congelamento ( $90 \%$ SBF e $10 \%$ DMSO) ou utilizadas em procedimentos experimentais. Em todo caso, as CTM foram utilizadas até no máximo a sexta passagem.

Para obter o meio condicionado dos linfócitos TCD3+, inicialmente foram obtidas células $T C D 3+$ que foram ativadas com beads que contém o coquetel de ativação CD2, CD3 e CD28, na proporção de 1bead:2células e foram mantidas em cultivo por 3 dias. Após os três dias de cultivo, os linfócitos TCD3+ e os meios condicionados foram coletados para os processos de centrifugação. Foram determinados três grupos experimentais: (I)SbCD3: sobrenadante de CD3; (II)SbCD3U: sobrenadante que passou por um processo de ultracentrifugação e (III)SbCD3P: que contém a solução ressuspensa do pellet obtido na ultracentrifugação (rico em microvesiculas). Para o grupo ultracentrifugado, o meio condicionado foi primeiro centrifugado a $2.000 \mathrm{~g}$ durante 20 minutos a $4^{\circ} \mathrm{C}$ para remover debris celulares. $O$ sobrenadante foi adicionalmente ultracentrifugado a $100000 \mathrm{~g}$ durante 1 hora a $4^{\circ} \mathrm{C}$ (Sorvall WX Ultra 80, rotor AH629, Thermo Fisher Scienti fic), obtendo assim $O$ sobrenadante livre de microvesículas (KERKELA et al., 2016; KILPINEN et al., 2013).

As CTMs também foram estimuladas, por 3 dias, mediante a cultura com adição de citocinas inflamatórias, como TNFa $(50 \mathrm{ng} / \mathrm{mL})$ (LERRER et al., 2017), IFNg (50 $\mathrm{ng} / \mathrm{mL})$ (POLCHERT et al., 2008), IL-1b $(20 \mathrm{ng} / \mathrm{mL})$ (BROEKMAN et al., 2016) e IL-6 $(40 \mathrm{ng} / \mathrm{mL})$. Para isto, foram plaqueadas $10^{4}$ CTMs em placas de 24 poços e foi aguardado um período de $24 \mathrm{~h}$ para estas aderirem e estabilizarem. As células também foram mantidas por $72 \mathrm{~h}$, na ausência ou na presença de agonistas ou antagonistas de receptores de adenosina nas respectivas concentrações: NECA a 300nM (agonista dos 4 receptores), CGS a 30nM (agonista de A2a), ZM a 25nM (antagonista de A2a), ZM* a 1500nM (antagonista dos 4 receptores), PSB a 10nM (antagonista de A2b), IB-Meca a 4nM (agonista de A3) e adenosina a 100nM (agonista de A1). 


\section{Obtenção das Células Mononucleares do Sangue Periférico}

As células mononucleares do sangue periférico (PBMC) foram fornecidas por doadores saudáveis. Uma vez coletada amostras de sangue periférico, foi adicionado PBS em volume correspondente a três vezes o volume sanguíneo, sendo a solução sanguínea disposta na parte superior do gradiente de centrifugação Ficoll-Hypaque (GE Healthcare; Piscataway, NJ, EUA), seguido da centrifugação a $2.500 \mathrm{rpm}$ por 30 minutos para separação das frações celulares. Posteriormente, foi coletada a fração correspondente as PBMC e efetuadas três lavagens em PBS a 1.500 rpm por 10 minutos, seguido da quantificação do número de células através da contagem em câmara de Neubauer.

\section{Separação imunomagnética dos linfócitos T}

A separação imunomagnética da população de linfócitos $T$ foi realizada com auxílio do kit comercial: Pan T Cell Isolation Kit II, human (Miltenyi Biotec; Bergisch Gladbach, Alemanha). Resumidamente, após a obtenção das PBMC, as células não-T (B, NK, monócitos, células dendríticas, granulócitos, plaquetas e eritrócitos) foram marcadas, ao serem incubadas com $10 \mu \mathrm{L} / 10^{7}$ células de um coquetel de anticorpos biotinilados contra CD14, CD16, CD19, CD56, CD36, CD123, TCR e CD235a. Em seguida, foram adicionados $30 \mu \mathrm{L} / 10^{7}$ células de tampão de coluna (PBS, $0,6 \%$ ACD e $0,5 \%$ albumina) e $20 \mu \mathrm{L} / 10^{7}$ células de partículas magnéticas (beads) ligadas a anticorpos anti-biotina, possibilitando a sua ligação a células marcadas com anticorpos. Deste modo, as células foram dispostas em uma coluna separadora LS (Miltenyi Biotec; Bergisch Gladbach, Alemanha) na presença de um imã SuperMACS (Miltenyi Biotec; Bergisch Gladbach, Alemanha), sendo lavadas com tampão de coluna (PBS 1X, 0,6\% ACD e 0,5\% albumina) no intuito de reter as células não-T na coluna separadora. Finalmente, as células $T$ isoladas foram lavadas com tampão de coluna a $1.500 \mathrm{rpm}$ por 10 minutos, ressuspensas em PBS e utilizadas para marcação intracelular ou análise de pureza. Para análise da 
pureza e caracterização da composição da amostra em citometria de fluxo, cerca de $2 \times 10^{5}$ células foram dispostas em dois tubos de ensaio contendo 100 $\mu \mathrm{L}$ de PBS, sendo em um destes adicionado $5 \mu \mathrm{L}$ do anticorpo anti-CD3 conjugado a FITC (Becton Dickinson, San Jose, CA, EUA) e ao outro (controle) adicionado $5 \mu \mathrm{L}$ de isotipo controle IgG1 FITC, IgG2a PE (BD-Biosciences; San Diego, CA, EUA), por um período de incubação de 20 minutos a temperatura ambiente. As amostras foram então centrifugadas a $1800 \mathrm{rpm}$ por 5 minutos, sendo então descartado o sobrenadante e as células ressuspensas em uma solução de Formol a $2 \%$ em PBS, para então serem analisadas por citometria de fluxo. Durante a análise no sofware Flow Jo VX, foi estabelecido o quadrante correspondente a intensidade de fluorescência observada pelas células incubadas com o isotipo controle, sendo então utilizado para mensurar a porcentagem de células T CD3+, na população de células marcadas com o anticorpo anti-CD3 conjugado a FITC. Com o intuito de mimetizar a indução in vivo de ativação dos linfócitos, foi utilizado o produto comercial: $T$ cell activation/expansion kit, human (Miltenyi Biotec; Bergisch Gladbach, Alemanha). Resumidamente, a partir de reagentes fornecidos pelo fabricante, foi feita uma solução composta por anticorpos biotinilados contra os receptores CD2, CD3 e CD28, ao qual foi adicionado partículas (beads) e uma solução tampão (PBS, $0.5 \%$ albumina sérica humana e $2 \mathrm{mM} \mathrm{ACD}$ ), sendo posicionada em um rotor de tubo PTR-35 (GRANT; Cambridge, Reino Unido) mantido a $40 \mathrm{C}$, por duas horas, no intuito de permitir a ligação entre beads e anticorpos. Após este período, foi adicionado meio RPMI para atingir uma concentração de $2 \times 10^{7}$ bead/500 $\mu \mathrm{L}$, sendo uma alíquota da solução transferida para os linfócitos, a uma razão linfócito:bead de 2:1, por um período de 5 minutos. Após este período, os linfócitos ativados foram cultivados isoladamente para formação do grupo controle positivo, ou co-cultivados com as CTM a razões linfócitos.

\section{Citometria de fluxo}


Nos ensaios descritos que necessitaram de análise por citometria de fluxo, o citômetro FACSCalibur (Becton Dickinson; San Jose, CA, EUA) foi utilizado para aquisição de células. Em todo caso, um total de 10.000 eventos foram adquiridos para posterior análise no software FlowJo Vx (Tree Star, Ashland, OR, EUA). Quando necessário, populações celulares foram isoladas, através da estratégia de gate, sendo então analisadas as intensidades de fluorescência nas populações celulares de interesse.

\section{Extração de RNA}

Para extração de mRNA, foi utilizado 0 reagente Trizol, seguindo o protocolo do fabricante. Em suma, foram utilizadas aproximadamente $1 \times 10^{6}$ células para cada extração. Após peletadas, foi adicionado às células o reagente de lise QIAzol e posteriormente clorofórmio. Após centrifugação, o homogenato foi separado em 2 fases: uma aquosa contendo o RNA total e outra orgânica contendo o DNA e proteínas. A fase aquosa foi recolhida e etanol foi adicionado para que todas as moléculas de RNA fiquem em condições de se ligarem a coluna. Essa mistura foi adicionada à coluna que posteriormente passa por uma centrifugação. Logo após, essa coluna foi lavada com os tampões do kit para que todos os contaminantes, como fenol, fossem retirados. Então, o RNA foi eluído pela adição de 30uL de água tratada com DEPC na coluna e posterior centrifugação. A quantificação foi obtida utilizando $1 \mathrm{uL}$ da amostra, com o espectrofotômetro Nanodrop 1000 (ThermoScientific).

\section{Análise de expressão gênica}

A análise de expressão gênica das CTMs tratadas foi realizada em ensaios de PCR quantitativo (qPCR), com o cDNA das CTM, reagente TaqMan Universal MIX II - NO UNG (AppliedBiosystems; Foster City, CA, EUA) e sondas TaqMan ("Assayondemand", tabela 1), em um aparelho BioRad CFX96 
Real Time System (Bio-Rad, Hercules, CA). As condições de termociclagem compreenderam uma incubação a $50^{\circ} \mathrm{C}$ por 2 minutos, $95^{\circ} \mathrm{C}$ por 10 minutos (ativação da DNA polimerase), seguidos por 40 ciclos de $95^{\circ} \mathrm{C}$ por 15 segundos (desnaturação) e $60^{\circ} \mathrm{C}$ por 1 minuto (anelamento e extensão simultâneos), sendo os resultados de CT exportados para planilhas no software Microsoft Excel, utilizando o software Bio-Rad CFX manager. Os resultados dos ensaios de GPCR (CT), provenientes do cDNA de CTM estimuladas.

\section{Microscopia de fluorescência quantitativa}

A expressão de CD39 e CD73 também foi estudada por meio de imunofluorescência. Para isto utilizamos o cocultivo de células estromais mesenquimais com linfócitos T CD3+ com intuito de observar se haveria alterações na localização das ectonucleotidases CD39/CD73 nas CTMs como especulado por KERKELA (2016). Assim, inicialmente foram cultivadas $1 \times 10^{4}$ células mesenquimais por poço em placas de 96 poços com meio alpha MEM + $15 \%$ soro fetal bovino. Paralelamente foram obtidos linfócitos efetores CD3+, foram isolados a partir de células mononucleares de sangue periférico (previamente separadas pela técnica de Ficoll-Hypaque) com o uso do kit comercial Pan T Cell Isolation Kit (Miltenyi Biotec-MACS). As amostras com alta porcentagem $(>96 \%)$ de pureza foram utilizadas para os ensaios de cocultivo.

Em seguida, o meio de cultura das células mesenquimais foi substituído por uma suspensão de linfócitos T ativados (na razão de linfócitos $20: 1$ CTM) em meio RPMI suplementado com $10 \%$ de soro fetal bovino (HyClone). As células foram co-cultivadas durante 3 dias e ao final foi realizada a fixação e marcação. Nesta etapa, o meio de cultura foi removido dos poços e, em seguida, foram realizadas duas lavagens com PBS (100 uL). O próximo passo foi a adição de $100 \mathrm{uL}$ do fixador (formol $2 \%$ em Metanol) gelado em cada poço de cultura e a placa foi mantida em freezer $\left(-20^{\circ} \mathrm{C}\right)$ por 20 minutos. Após este período, foram adicionados sobre o fixador mais 100 uL de PBS. A mistura 
$\mathrm{PBS} / \mathrm{MeOH}$ foi retirada logo em seguida para que a células fossem lavadas por mais duas vezes com $100 \mathrm{uL}$ de PBS. As etapas seguintes foram de quenching com glicina ( $0,1 \mathrm{M}$ por 15 minutos) e bloqueio (30 minutos em PBS/SBF 1\%). A marcação com os anticorpos foi realizada utilizando-se 1 uL/poço de cada anticorpo diluído em solução de bloqueio, nesta mesma solução já continha o marcador nuclear, Hoechst 33342(1:1000) e o marcador celular (HCS CellMask ${ }^{\circledR}$ Blue 1:10000) seguida de uma incubação por 30 minutos. Por fim, foram mantidos $100 \mathrm{uL}$ de PBS por poço e as placas foram levadas ao equipamento de HCS para a aquisição das imagens.

Para a aquisição das imagens, foi utilizado o sistema automatizado de microscopia de fluorescencia quantitativa - HCS ImageXpress XL (Molecular Devices). Com este sistema, pode-se avaliar vários parâmetros simultaneamente. O princípio básico destas análises consiste em demarcar o(s) compartimento(s) celular(es) de interesse (segmentação da imagem), de maneira que o sinal derivado de outros reagentes de detecção possa ser quantificado exclusivamente nas regiões de interesse. Assim, diversas avaliações quantitativas e qualitativas podem ser realizadas, incluindo intensidades de marcação nas regiões analisadas, bem como alterações morfológicas associadas (TAYLOR, 2007).

Foram obtidas imagens de 9 sítios dentro de 6 poços de cocultivo utilizando-se a objetiva de 10X e os cubos com filtros de excitação e emissão ideais para cada fluoróforo. Os cubos utilizados foram de DAPI (para Hoechst 33342 e CellMaskBlue que garantiram intensidades de fluorescência diferentes para o os núcleos do linfócito e para a mesenquimal), Cy3 (para CD73 PE) e Texas Red (para CD39 APC). O software utilizado para aquisição das imagens foi o MetaXpress (Molecular Devices).

\section{Análise das imagens de microscopia quantitativa - High Content Analysis}


As imagens geradas na etapa anterior foram exportadas para serem analisadas com o uso do software de licença aberta CellProfiler 2.2. Esse software permite que sejam extraídos dados quantitativos a partir de fotomicrografias obtidas em microscópios de luz transmitida ou fluorescência. Foram obtidas aqui informações sobre a morfologia das células, localização e intensidade de fluorescência dos marcadores utilizados.

Na pipeline criada no CellProfiller, inicialmente os núcleos dos linfócitos (objetos primários) foram identificados pela maior intensidade de fluorescência de Hoechst, menor tamanho e pela exclusão dos núcleos das células CTM (Figura X-A). Em seguida, a região celular de cada linfócito foi definida pela expansão do núcleo, utilizando o sinal citoplasmático do corante CellMask Blue (objeto secundário, Figura X-B). Em seguida, foi identificada a região de contato dos linfócitos com as mesenquimais, definida como a região imediatamente circundante do linfócito (obtida a partir da expansão de 12 pixels do objeto secundário). Para definir e segmentar a área ocupada pelas CTM foi utilizado o marcador CD73 (positivo nas CTM), com ele foi possível gerar uma máscara de imagem contendo apenas a marcação das células mesenquimais. Finalmente, foram quantificadas as intensidades de fluorescência das três regiões: apenas linfócitos (região CD3+), apenas CTMs (região CTM) e a região da CTM ao redor dos linfócitos (região de interação). 

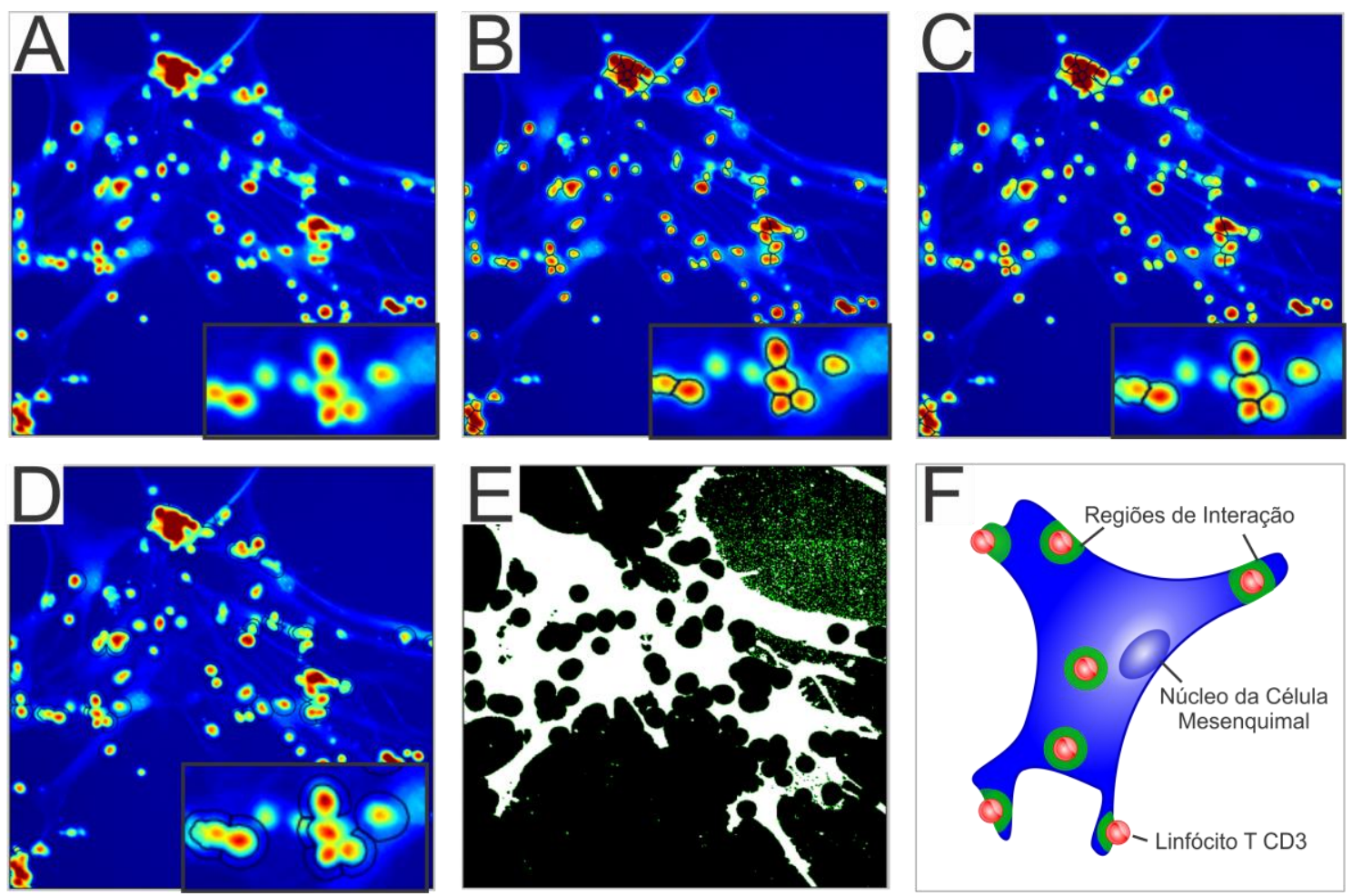

Figura 9. Esquema da pipeline criada para analisar as imagens. As imagens são uma representação normalizada em log no canal de DAPI, utilizando-se uma ferramenta que muda a cor em proporção da intensidade do sinal (do azul, para menor intensidade, ao vermelho, para maior intensidade). Pode-se notar que o núcleo apresenta-se em vermelho, por ser fortemente marcado por Hoechst 33342, enquando - citoplasma encontra-se num tom azul-esverdeado, pela marcação com CellMask®Blue. A- Color map: Imagem de Hoechst e CellMaskBlue B- Identificação das regiões mais brilhantes (centro dos linfócitos) C- Expansão da área central dos linfócitos (objeto que representará o linfócito para as quantificações) D- Região de interação entre o linfócito e a mesenquimal (expansão a partir do objeto "linfócito") EIdentificação da área ocupada pelas células mesenquimais (sem sobreposição com a área dos linfócitos e seus arredores) - em branco. F- Figura ilustrativa acerca das regiões de máscaras criadas com a pipeline.

A tabela de dados obtidas por meio do CellProfiler apresenta um grande número de informações, ou seja, é o resultado da análise de alto conteúdo (High Content Analysis). Este grande número de dados pode ser melhor estudado e organizado utilizando-se softwares específicos de gerenciamento de dados,como o KNIME. Dessa forma, inicialmente foram inseridos os dados brutos obtidos das análises com o CellProfiler, sendo utilizado o node de leitura de arquivos pra isso. Para prosseguir com o gerenciamento dos dados, outros nodes foram adicionados, como:- "filtros de coluna", para retirar informações que não seriam relevantes para as análises;- "agrupar por", para agrupar inicialmente os dados dos sítios, gerando informações por poço e, depois, as 
informações dos poços, para gerar os dados por tratamento;- "gerador de CSV", que exportou para uma tabela os dados reorganizados, filtrados e analisados no KNIME.

\section{Análises estatísticas}

O software Graphpad Prism 5.0 foi utilizado para todas as análises estatísticas realizadas neste trabalho. Análises paramétricas foram utilizadas para comparações entre dois ("teste t de student") ou mais ("One-Way ANOVA") grupos experimentais, havendo a comparação dos grupos experimentais entre si (pós-teste de Tukey), quando necessário. Em todo caso, os resultados foram considerados estatisticamente significativos quando $p<0.05$. 
12- RESUltados 
Expressão gênica de $A D A, C D 39, C D 73$ e receptores de adenosina em CTMs

Inicialmente, avaliamos a expressão gênica dos receptores de adenosina nas MSCs, assim como da enzima ADA, que converte a adenosina em inosina, e de CD39 e CD73 (Figura 9). Em acordo com CAVALIERE; DONNO; D'AMBROSI (2015), observa-se que as MSCs possuem a expressão do receptor $\mathrm{A} 2 \mathrm{~B}$ como subtipo predominante juntamente com uma elevada expressão de ADA. Ainda, os transcritos de CD73 estavam em níveis mais elevados que os de CD39, em linha com o observado a nível proteico, por citometria de fluxo.

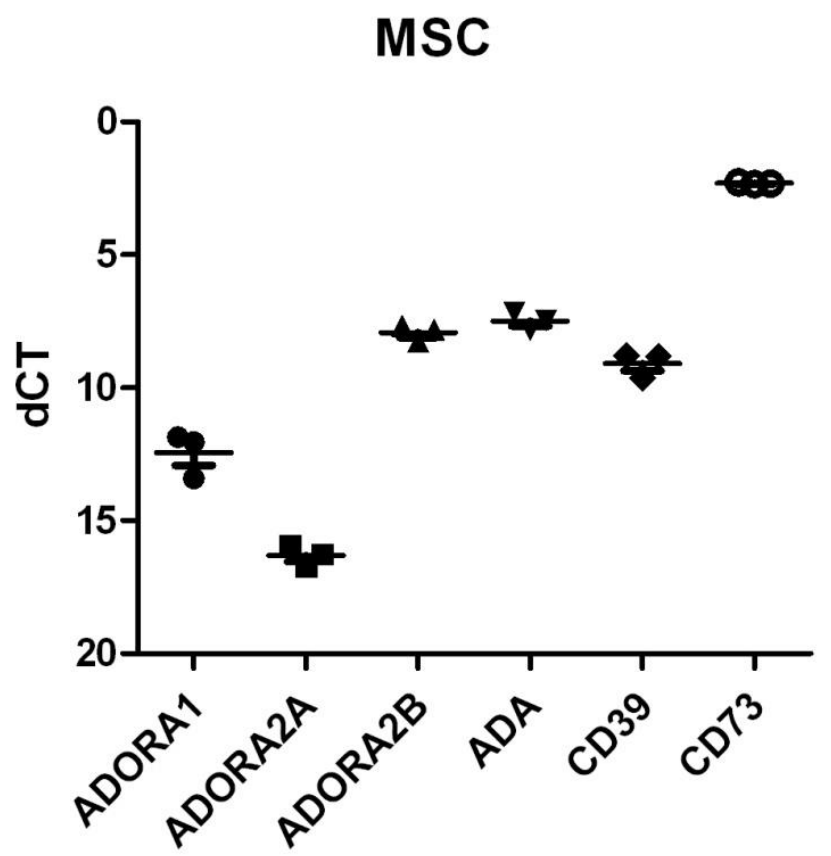

Figura 10. Expressão gênica de $A D A, C D 39, C D 73$ e receptores de adenosina em CTMs. Células mesenquimais estromais foram cultivadas por 3 dias com alphaMEM $+15 \%$ soro fetal bovino para coleta do RNA, transcrição e análise da expressão. As amostras foram normalizadas com base na expressão do gene endógeno GAPDH para o cálculo de deltaCt. Triplicata biológica ( $N=3$, três doadores).

\section{Efeito dos estímulos inflamatórios na expressão genica de ADA, CD39, CD73 e receptores de adenosina em CTMs}

A expressão relativa do gene ADORA2A, que codifica o receptor A2a de adenosina, não apresentou aumento significativo nas CTM cultivadas com estímulos inflamatórios, como II-6, IL-1B e INF-g, quando comparados à cultura 
das CTMs sem tratamento. Por outro lado, é possível observar que o tratamento com TNF-a induziu a expressão de ADORA2A. Interessantemente, a expressão de ADORA2A teve um aumento significativo $(P<0,001)$ nas CTMs submetidas aos tratamentos com os meios sobrenadantes condicionados pela cultura de linfócitos T CD3+ ativados, com um aumento médio de 35 vezes com o sobrenadante total, assim como um aumento médio de aproximadamente 60 vezes com 0 tratamento com 0 sobrenadante ultracentrifugado (com a depleção de microvesículas), e um aumento médio aproximado de 30 vezes nas CTMs submetidas ao tratamento com o pellet do sobrenadante ultracentrifugado, enriquecido com microvesículas.

C D 39

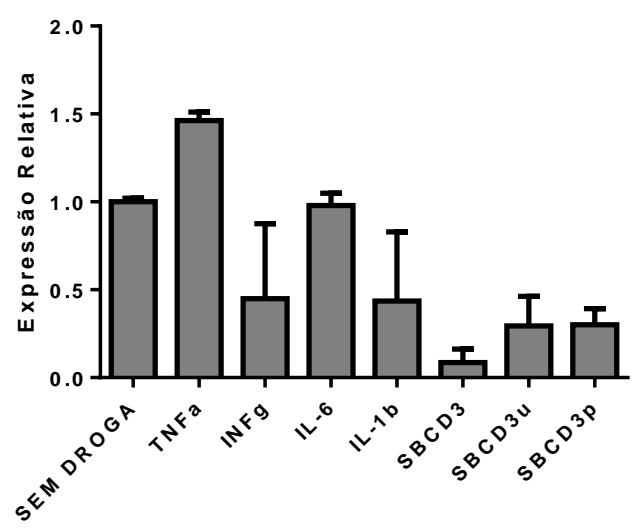

C D 73

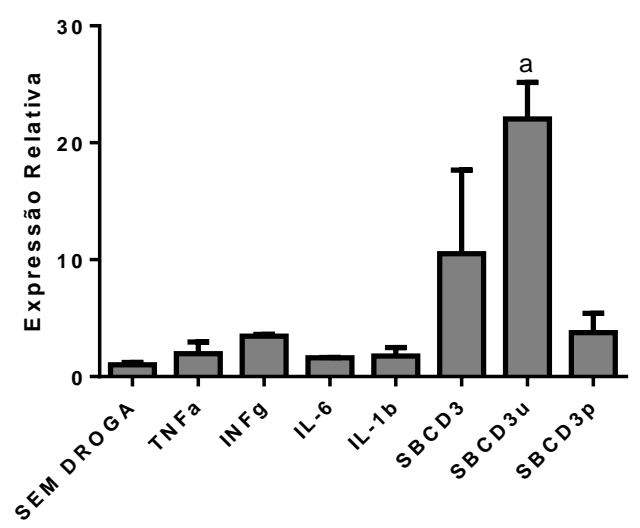

Figura 11. Efeito dos estímulos inflamatórios na expressão gênica de CD39 e CD73 em CTMs. Gráfico representativo da expressão relativa do gene ADORA A nas CTMs submetidas ao tratamento, durante 3 dias, na ausência ou na presença de estímulos com citocinas inflamatórias, assim como nas soluções obtidas a partir do meio condicionado gerado pelas células CD3, A expressão relativa $\left(2^{\wedge}\right.$-ddCt) foi obtida com base na normalização das amostras pela expressão do gene GAPDH e com base na amostra sem tratamento como amostra controle. $a={ }^{*} p<0,05$ em relação ao controle. Triplicata experimental $(\mathrm{N}=1)$. 
ADA
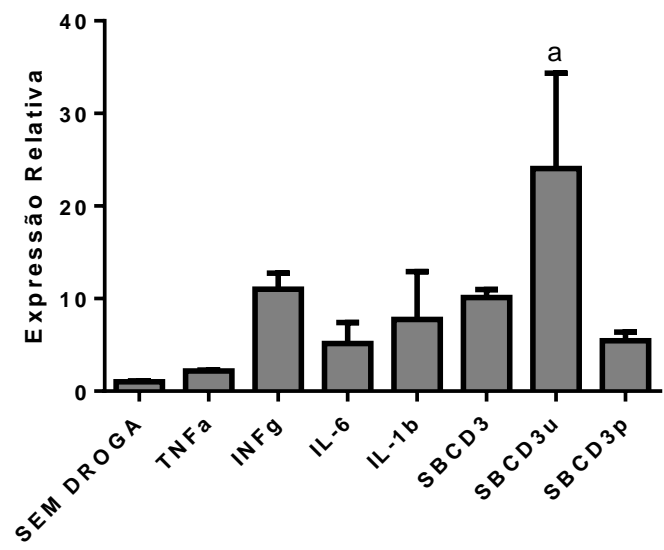

A D O R A 2a

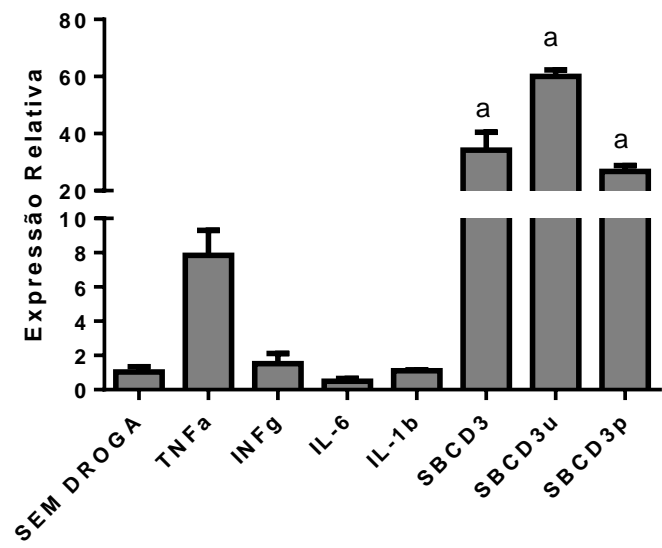

ADORA 1

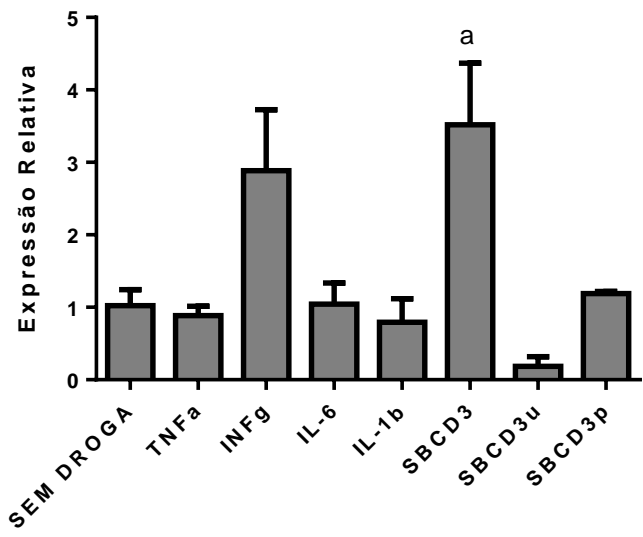

ADORA2b

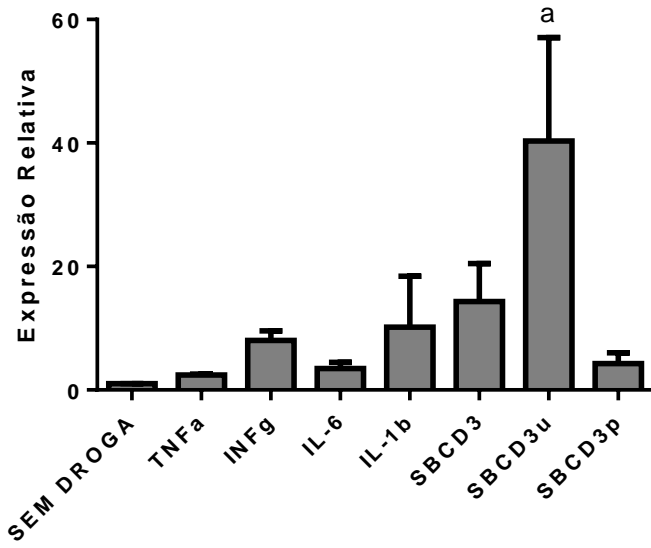

Figura 11. Expressão Relativa de ADA e receptores de adenosina em CTMs. Gráfico representativo da expressão relativa do gene ADORA A nas CTMs submetidas ao tratamento, durante 3 dias, na ausência ou na presença de estímulos com citocinas inflamatórias, assim como nas soluções obtidas a partir do meio condicionado gerado pelas células CD3 ativadas com beads anti-CD2/CD3/CD28 e cultivadas por 3 dias na presença de IL-2. A expressão relativa $\left(2^{\wedge}-\mathrm{ddCt}\right)$ foi obtida com base na normalização das amostras pela expressão do gene GAPDH e com base na amostra sem tratamento como amostra controle. Triplicata experimental ( $\mathrm{N}=1$, um doador). 


\section{Efeito dos estímulos inflamatórios na expressão proteica e localização celular de CD39 e CD73 em CTMs}

Para obter o meio condicionado, inicialmente foram obtidas células $T$ CD3+ isoladas do sangue periférico pela técnica de Ficoll-Hypaque e separadas imunomagneticamente com o uso do kit comercial Pan $\mathrm{T}$ Cell Isolation Kit (Miltenyi Biotec-MACS) que foram ativadas com beads que contém o coquetel de ativação CD2, CD3 e CD28, na proporção de 1bead:2células e foram mantidas em cultivo por 3 dias. O sobrenadante desta cultura foi coletado e dividido em três grupos: SbCD3: sobrenadante de CD3; SbCD3U: sobrenadante que passou por um processo de ultracentrifugação e SbCD3P: que contém o pellet obtido na ultracentrifugação (rico em microvesiculas) ressuspenso no mesmo volume original do meio ultracentrifugado. As MSCs também foram estimuladas, por 3 dias, mediante a cultura com adição de citocinas inflamatórias, como TNFa, IFNg, IL-1b e IL-6.

É possível observar que houve uma diferença significativa na expressão de CD39 na superfície das MSCs cultivadas com a solução que contém as microvesículas do ultracentrifugado do mesmo condicionado pelas CD3 entretanto o mesmo não pode ser observado na expressão de CD39 intracelular mediante o mesmo tratamento. Assim como é possível observar que não houve diferença significativa na expressão de $C D 73$, tanto na superfície como na sua forma intracelular, mediante qualquer tratamento. É possível observar, uma discreta variação (dados não significativos) na expressão concomitante de CD39 e CD73 no interior das MSCs com os diferentes tratamentos. 

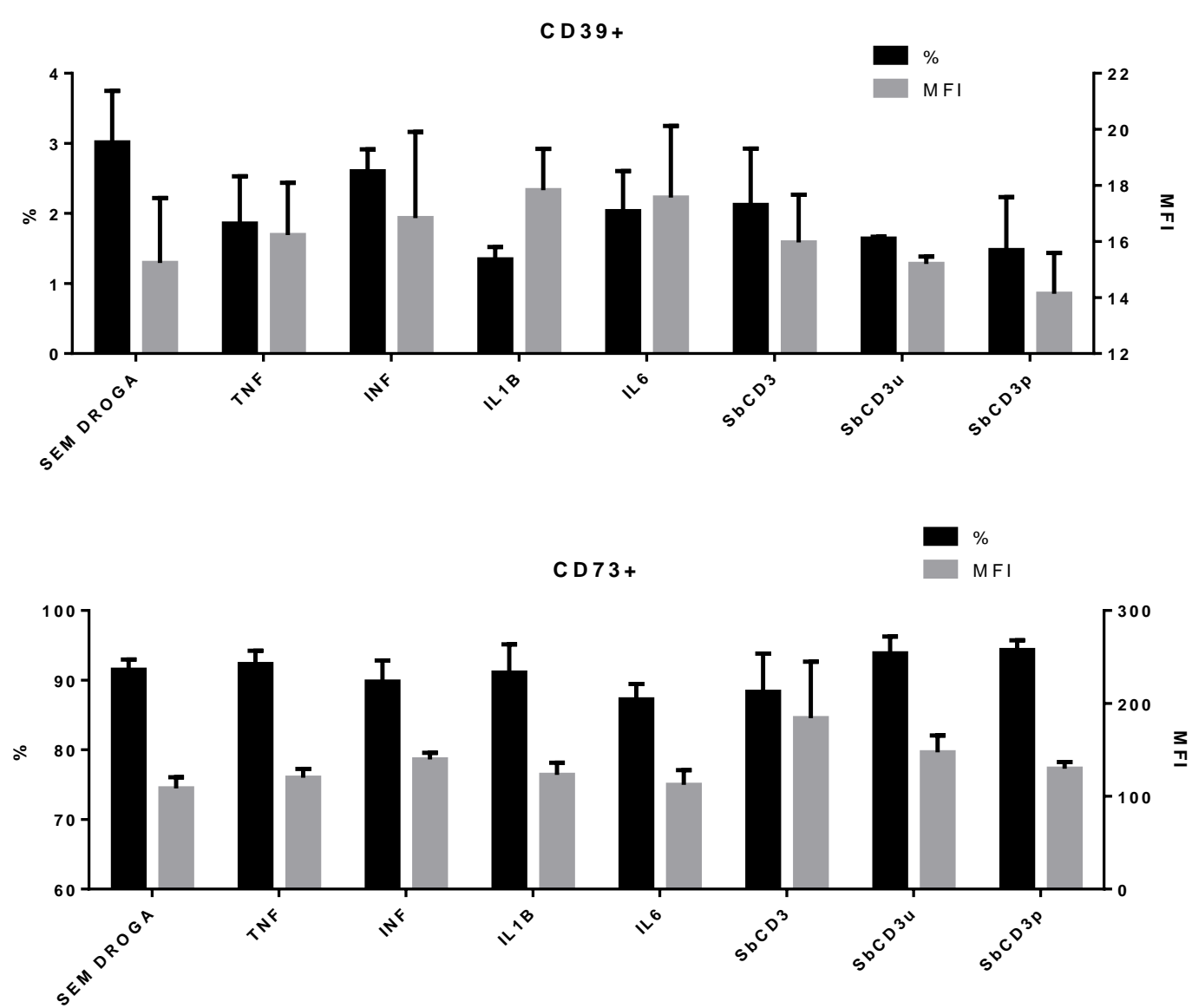

Figura 7. Efeito dos estímulos inflamatórios na porcentagem de CTMs expressando CD39 e CD73 de superfície. Células mesenquimais estromais foram cultivadas por 3 dias com alphaMEM $+15 \%$ soro fetal bovino, na presença ou ausência de suplementação com citocinas ou estímulo do sobrenadante da cultura dos linfócitos CD3+ ativados. A porcentagem de células positivas se encontra na escala do eixo y a esquerda e os valores referentes a Intensidade Média de Fluorescência (MFI) foram plotados usando o eixo y da direita. Triplicata experimental ( $\mathrm{N}=1$, um doador). 

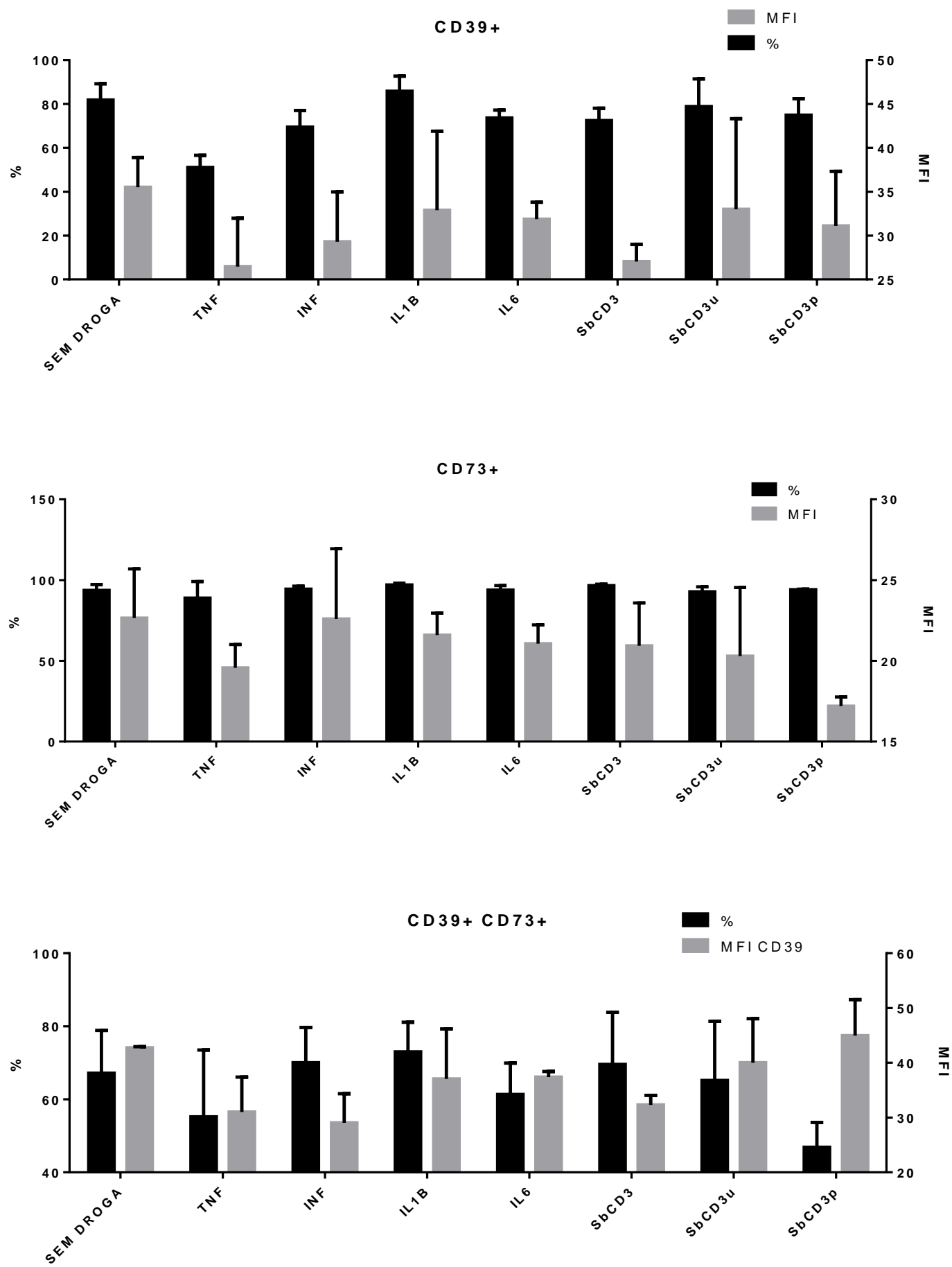

Figura 13. Efeito dos estímulos inflamatórios na porcentagem de CTMs expressando CD39 e CD73 intracelular. Células mesenquimais estromais foram cultivadas por 3 dias com alphaMEM $+15 \%$ soro fetal bovino, na presença ou ausência de suplementação com citocinas ou estímulo do sobrenadante da cultura dos linfócitos CD3+ ativados. A porcentagem de células positivas se encontra na escala do eixo y a esquerda e os valores referentes a Intensidade Média de Fluorescência (MFI) foram plotados usando o eixo y da direita. Triplicata experimental ( $\mathrm{N}=1$, um doador). 


\section{Direcionamento de CD39 e CD73 nas CTMs, para a região de interação com linfócitos $\mathrm{T}$ ativados}

A partir das segmentações e quantificações realizadas, observamos os dados relativos a mediana da média das intensidades de fluorescência (Figura 17 superior). Observa-se que na zona identificada como interação há um significativo aumento de intensidade de CD39 e também de CD73, em relação a zona onde não há o contato da célula $\mathrm{CD} 3+$. A razão entre os valores de maração para CD39 entre a zona de interação e as CTMs foi de 1,63 em média e de 1,2 para CD73. Para melhor esclarecer estas relações, faz-se necessário incluir a marcação isolada de células CTMs e CD3+ fora do co-cultivo. Adicionalmente observamos também um aumento das projeções de membrana plasmática das células mesenquimais, o que pode se caracterizar como uma possível estratégia de aumento de superfície de contato para interação com os linfócitos. 

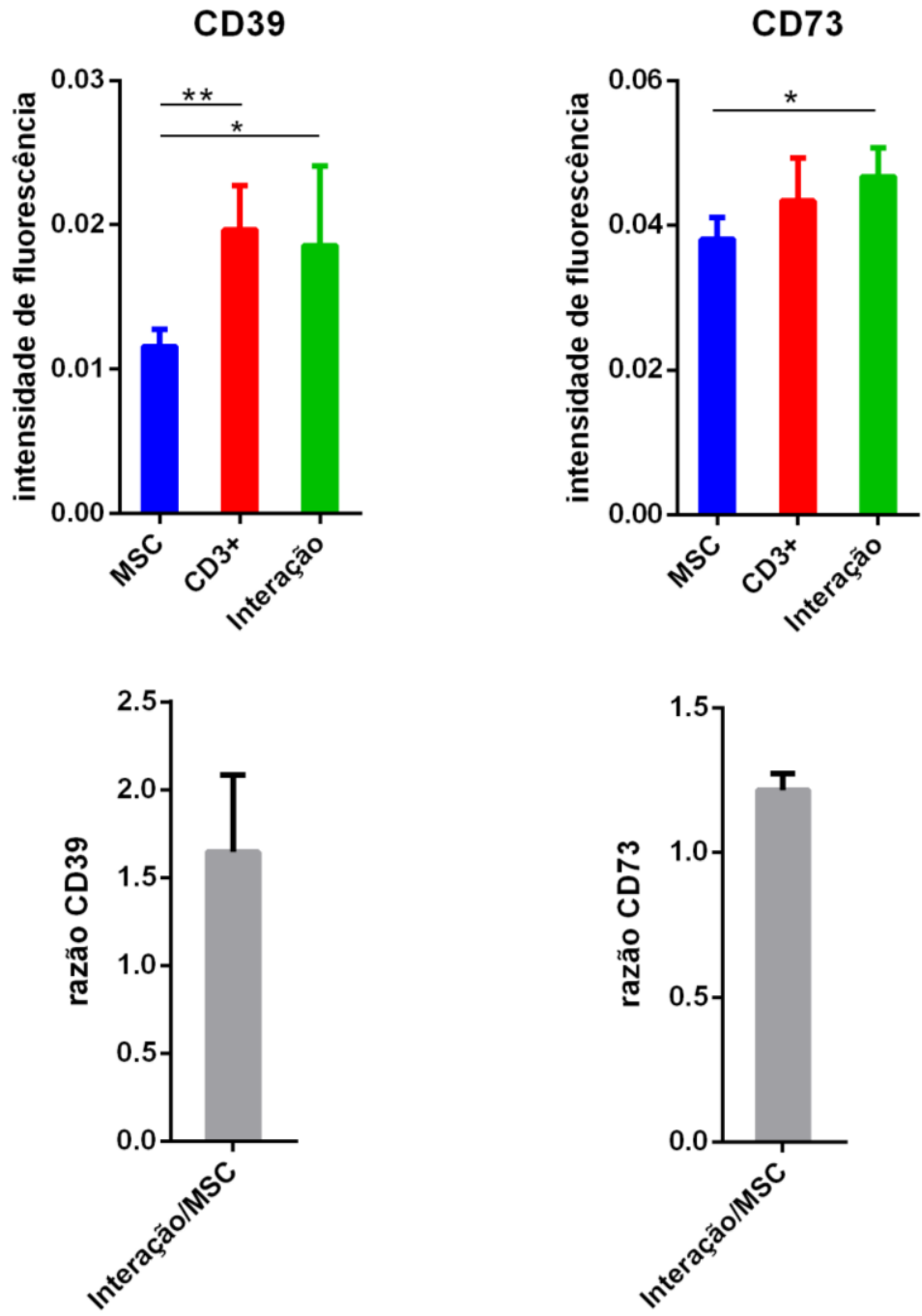

Figura 14. Intensidade de fluorescência de CD39 e CD73 nas três regiões identificadas como CTM, CD3 e zona de interação. Células mesenquimais estromais foram cultivadas por 3 dias com linfócitos CD3 ativados. Medianas das intensidades médias de fluorescência. Quadruplicata experimental (N=1). 
13- DisCuSSÃo 
Crescentes evidências trouxeram consciência para a notável variedade de moléculas bioativas produzidas pelas CTMs. Hoje em dia, é opinião comum que o amplo repertório de fatores secretados produzidos por elas, geralmente referido como o secretoma das CTMs, desempenha um papel importante quando estas células são administradas visando reparação tecidual. O papel autócrino/parácrino dessas moléculas está sendo cada vez mais reconhecido como chave para a regulação de muitos processos fisiológicos, incluindo o direcionamento de células endógenas e progenitoras para locais de lesão, bem como a mediação de apoptose, cicatrização e revascularização tecidual (BERNARDO; FIBBE, 2013). Neste trabalho, avaliamos a expressão de uma ectoenzima capaz de produzir adenosina, que é uma desta moléculas bioativas atuantes durante a imunomodulação das CTMs.

Inicialmente, observamos que em acordo com CAVALIERE et al. (2015), observa-se que as MSCs possuem a expressão do receptor A2B como subtipo predominante juntamente com uma elevada expressão de ADA. Ainda, os transcritos de CD73 estavam em níveis mais elevados que os de CD39, em linha com o observado a nível proteico, por citometria de fluxo.

\section{Estímulos inflamatórios em CTMs}

As alterações dinâmicas no nicho inflamatório dos distúrbios relacionados ao sistema imunológico são sempre acompanhadas de alterações do tipo e quantidade de citocinas inflamatórias. Por exemplo, altas concentrações de citocinas pró-inflamatórias, como TNF- $\alpha$, IFN- $\gamma$, IL-6 e IL-1 $\beta$ dominam na fase inflamatória aguda. Evidências crescentes sugerem que os tipos e quantidades de citocinas inflamatórias presentes no nicho inflamatório ditam como as CTM regulam a inflamação (BERNARDO; FIBBE, 2013). Com isto, realizamos tratamentos com estímulos inflamatórios e observamos que não houve alterações na expressão das ectonucleotidases por citometria de fluxo. Entretanto, ao observarmos a expressão relativa de CD39 (mRNA) vemos que o tratamento com TNF- $\alpha$ apresentou aumento em relação ao controle, enquanto os outros estímulos inflamatórios não diferiram do controle. 


\section{Sobrenadantes de CD3+ e a exposição de CD39 em CTMs}

Microvesículas apresentam tamanhos variados em uma faixa de diâmetro de 200 a $1.000 \mathrm{~nm}$. Embora um grande número de proteínas seja comumente encontrado em exossomos independentemente de sua origem celular $(\mathrm{CHOl}$ et al., 2015), a composição protéica dos exossomos varia com o tipo de célula, refletindo de alguma forma as funções específicas da célula produtora. A secreção de exossomas e microvesículas a partir de diferentes tipos de células T tem sido demonstrada por vários grupos, por exemplo de células CD3 + ativadas (FOMINA et al., 2003), células T CD4 + (BLANCHARD et al., 2002) e células T CD8 + (TUMNE et al., 2009). Foi sugerido que os exossomos de células T CD4+ entregam sinais co-estimulatórios (FOMINA et al., 2003). Em células $T$ ativadas, o transporte de microvesículas tem papel fundamental na montagem e manutenção da estrutura de sinapse imunológica (zona de interface da célula $T$ e da apresentadora de antígeno). (FINETTI; CASSIOLI; BALDARI, 2017). A abordagem utilizada em nosso trabalho visou observar se microvesículas de linfócitos T CD3+ ativados estariam levando a um aumento na exposição de CD39 na superfície das CTMs. Apesar de não terem sido encontradas diferenças diretamente na expressão protéica das ectoenzimas, ao observarmos as quantificações de mRNA para CD73 vemos que houve um significativo aumento no grupo livre das microvesículas (SBCD3U). Também neste tratamento, observamos aumento de ADA e ADORA2b. Enquanto isso, ADORA1 teve sua expressão aumentada quando utilizado o sobrenadante não centrifugado (SBCD3+). Nota-se também que ADORA2A teve sua expressão significativamente maior em todas condições que foram utilizados os sobrenadantes.

\section{Localização de CD39 em coculturas}

Diversos processos imunomoduladores têm sido propostos para CTMs (KOVACH et al., 2015), que podem ser implantados na modulação da inflamação localizada em um ambiente particular. Estes mecanismos podem 
ser particularmente importantes na regulação de danos teciduais, onde nucleotídeos, como o ATP, estão disponíveis abundantemente no ambiente extracelular. Em nossos resultados, observamos uma localizada expressão de CD39 em coculturas de CTMs e linfócitos CD3+ ativados. Esta abordagem já foi utilizada em trabalho anteriores com o de KERKELA (2016) onde é sugerido que a produção de adenosina em CTMs requer cooperação com CD39 expressas por células T. Segundo ele, não há expressão membranar em CTMs de CD39, entretanto, SALDANHA-ARAUJO et al. (2011) já havia relatado o aumento da expressão de CD39 em CTMs em seu trabalho demonstrando cocultivo de CTMs com CD3+ ativadas. Em murinos, SATTLER et al. (2011) descreve também que CD39 é co-expressa com CD73 em CTMs, catalisando a geração de adenosina, que atua diretamente sobre células $T$ ativadas através do receptor de adenosina A2A.

Conforme SALDANHA-ARAUJO et al. (2011) relata, é possível que as CTM adquiram CD39 em sua superfície em determinadas situações, como em contato com células imunes ativadas. Isso pode ser mediado por vesículas extracelulares ou ativado por fatores solúveis. Com isto especulamos que em determinadas situações o CD39 intracelular poderia ser transportado para superfície celular. Tal aumento dos marcadores pode indicar um processo de imunomodulação localizado, dada a sobreposição aumentada das ectoenzimas nas zonas de interação, já que com isto a produção de adenosina (que tem rápida degradação) pode ser favorecida. Em acordo com KERKELA et al. (2016), ambém detectamos uma expressão citosólica abundante de CD39 por citometria de fluxo, o que indica que há potencial para atividade de hidrólise de ATP/ADP. No entanto, KERKELA (2017) relata que ao cultivar CTMs de cordão umbilical humano com células $T$ ativadas em um sistema transwell, a expressão de CD39 não aumentou na superfície de MSCs. Estes achados diferem dos nossos vistos pelo sistema do cocultivo, onde há o contato direto célula-célula.

CD39 (ecto-nucleosídeo trifosfato difosfohidrolase-1; E-NTPDase1) é uma ecto-enzima da membrana plasmática que regula a sinalização dos receptores purinérgicos, controlando os níveis de nucleotídeos extracelulares. O CD39 está localizado nas cavéolas, que são invaginações da membrana plasmática 
com composição lipídica distinta, semelhante aos microdomínios lipídicos dinâmicos, denominados rafts. KITTEL et al. (1999) observou que CD39 é preferencialmente direcionada a esses microdomínios de membrana chamados cavéolas principalmente em células ativadas como macrófagos induzidos (KISS; KITTEL, 1995), células de músculo liso tratadas com concanavalina $A$ ou em células endoteliais capilares tratadas com lipopolisacarídeos (ANDERSON, 1998). Outra observação foi que não só a atividade ectoATPase, mas também o número de caveolas dependia da condição de ativação celular. As células ativadas continham muito mais estruturas caveolares, comprovando sua importância em localizações dinâmicas da membrana plasmática (KITTEL et al., 1999).

Em neutrófilos, JUNGER (2011) descreve a visualização direta da liberação de ATP a partir de células vivas onde observa que o ATP é liberado de maneira polarizada, resultando no acúmulo de ATP extracelular próximo à superfície da célula mais próxima da fonte de quimioatrativos. JUNGER (2011) relata que durante esta polarização celular, moléculas sinalizadoras purinérgicas como a panexina 1, CD39 e receptores de adenosina translocam para a borda de contato, (Fig. 15) onde, na região ressaltada da membrana há liberação de ATP que localmente é convertido em adenosina por CD39. Por consequência, receptores de adenosina que estão concentrados também nas regiões de contato, são ativados e esse circuito de realimentação purinérgica promove o movimento de migração. Com isto, a localização de CD39 em rafts lipídicos favorece processos de sinalização dada sua distribuição espacial membranar. 


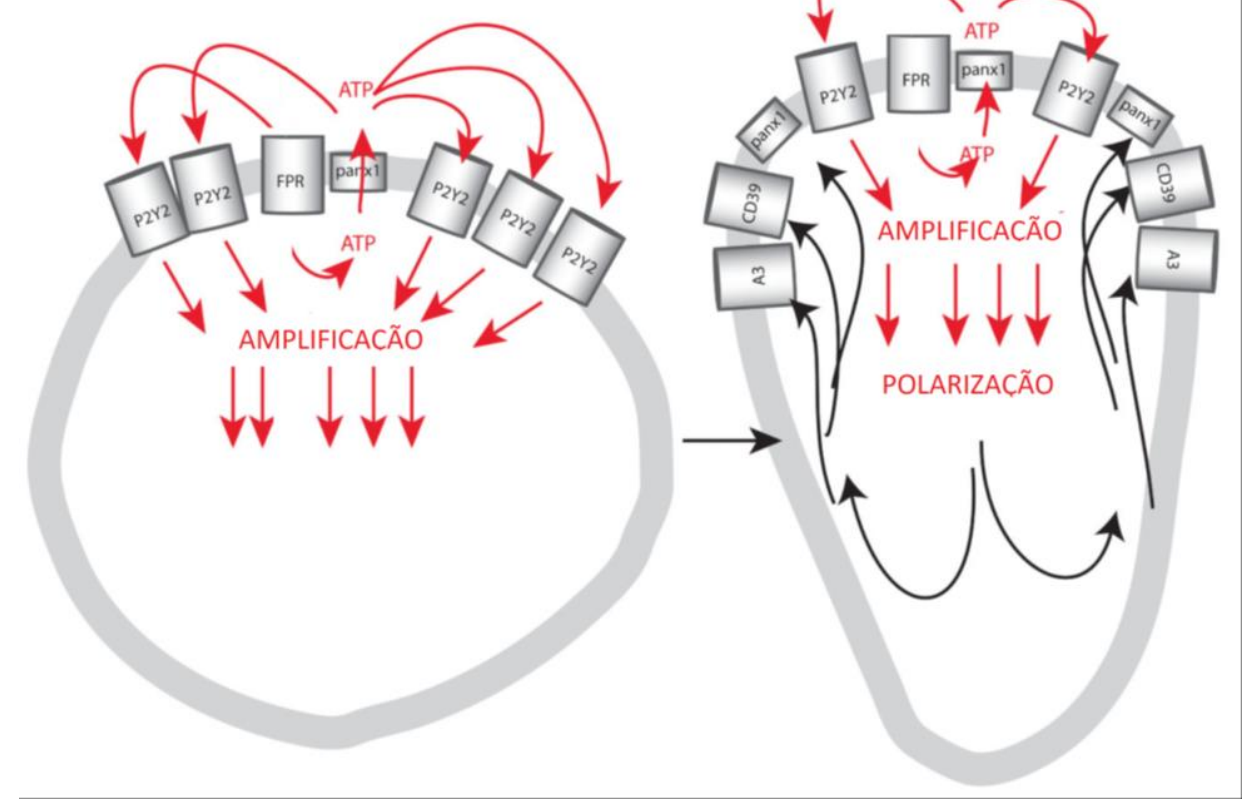

Figura 15. Amplificação do sinal purinérgico regula a quimiotaxia em neutrófilos. Em processos quimiotáticos determinada célula detecta quimioatratores e os reconhece no ambiente extracelular. A partir disto, ela pode assumir uma conformação polarizada, onde passa a uma forma alongada que se alinha dentro do campo de gradiente quimiotático. Ao mesmo tempo, receptores específicos e moléculas sinalizadoras translocam-se para as regiões periféricas mais próximas às zonas de contato. Adaptado de (JUNGER, 2011) 


\section{4- Conclusões}


Em relação a expressão de CD39 em células mesenquimais isoladas, observamos que o estímulo com citocinas pró inflamatórias ou com agonistas e antagonistas de receptores de adenosina não resultou em mudanças na expressão do receptor na membrana. Foi observada também significativa expressão citosólica CD39 em CTM por permeabilização.

A incubação de CTMs com sobrenadante de meios de cultura condicionados por linfócitos T ativados induziu uma expressão elevada de ADORA2A.

Quando foram observadas as células em co-culturas, as CTMs e os linfócitos T apresentaram um aumento significativo na expressão de CD39 e CD73 em regiões de contato entre CTM e CD3+. Nossos resultados indicam que este aumento da expressão de CD39/CD73 durante a interação de CTM e CD3+ pode estar relacionado às propriedades imunomoduladoras de CTMs. Estes dados podem abrir novas alternativas para o estudo da imunomodulação mediada por CTM e sua aplicação no desenvolvimento de novos tratamentos para GVHD e outras doenças inflamatórias 


\section{5- REFERÊNCIAS BIBLIOGRÁFICAS}


ABBAS, A. K. et al. T cell tolerance and autoimmunity. Autoimmun Rev, v. 3, n. 7-8, p. 471-5, Nov 2004.

AFZALI, B. et al. The role of $\mathrm{T}$ helper 17 (Th17) and regulatory $\mathrm{T}$ cells (Treg) in human organ transplantation and autoimmune disease. Clin Exp Immunol, v. 148, n. 1, p. 32-46, Apr 2007.

AIRAS, L. et al. Differential regulation and function of CD73, a glycosylphosphatidylinositol-linked 70-kD adhesion molecule, on lymphocytes and endothelial cells. J Cell Biol, v. 136, n. 2, p. 421-31, Jan 271997.

ALMEIDA, A. R. et al. Homeostasis of peripheral CD4+ T cells: IL-2R alpha and IL-2 shape a population of regulatory cells that controls CD4+ $T$ cell numbers. J Immunol, v. 169, n. 9, p. 4850-60, Nov 12002.

ANDERSON, R. G. The caveolae membrane system. Annu Rev Biochem, v. 67, p. 199-225, 1998.

ANDREEVA, E. et al. Interaction of multipotent mesenchymal stromal and immune cells: Bidirectional effects. Cytotherapy, v. 19, n. 10, p. 1152-1166, Oct 2017.

ANTONIOLI, L. et al. CD39 and CD73 in immunity and inflammation. Trends Mol Med, v. 19, n. 6, p. 355-67, Jun 2013.

BARKER, J. N. Umbilical Cord Blood (UCB) transplantation: an alternative to the use of unrelated volunteer donors? Hematology Am Soc Hematol Educ Program, p. 55-61, 2007.

BARLETTA, K. E.; LEY, K.; MEHRAD, B. Regulation of neutrophil function by adenosine. Arterioscler Thromb Vasc Biol, v. 32, n. 4, p. 856-64, Apr 2012.

BATTAGLIA, M. et al. Rapamycin promotes expansion of functional CD4+CD25+FOXP3+ regulatory $T$ cells of both healthy subjects and type 1 diabetic patients. J Immunol, v. 177, n. 12, p. 8338-47, Dec 152006.

BATTAGLIA, M.; STABILINI, A.; RONCAROLO, M. G. Rapamycin selectively expands CD4+CD25+FoxP3+ regulatory T cells. Blood, v. 105, n. 12, p. 47438, Jun 152005. 
BATTAGLIA, M.; STABILINI, A.; TRESOLDI, E. Expanding human T regulatory cells with the mTOR-inhibitor rapamycin. Methods Mol Biol, v. 821, p. 279-93, 2012.

BERNARDO, M. E.; FIBBE, W. E. Mesenchymal stromal cells: sensors and switchers of inflammation. Cell Stem Cell, v. 13, n. 4, p. 392-402, Oct 32013.

BLANCHARD, N. et al. TCR activation of human T cells induces the production of exosomes bearing the TCR/CD3/zeta complex. J Immunol, v. 168, n. 7, p. 3235-41, Apr 12002.

BOONSTRA, J. Progression through the G1-phase of the on-going cell cycle. $\mathbf{J}$ Cell Biochem, v. 90, n. 2, p. 244-52, Oct 12003.

BOPP, T. et al. Cyclic adenosine monophosphate is a key component of regulatory $\mathrm{T}$ cell-mediated suppression. J Exp Med, v. 204, n. 6, p. 1303-10, Jun 112007.

BORRMANN, T. et al. 1-alkyl-8-(piperazine-1-sulfonyl)phenylxanthines: development and characterization of adenosine $\mathrm{A} 2 \mathrm{~B}$ receptor antagonists and a new radioligand with subnanomolar affinity and subtype specificity. $J$ Med Chem, v. 52, n. 13, p. 3994-4006, Jul 92009.

BORSELLINO, G. et al. Expression of ectonucleotidase CD39 by Foxp3+ Treg cells: hydrolysis of extracellular ATP and immune suppression. Blood, v. 110, n. 4, p. 1225-32, Aug 152007.

BROEKMAN, W. et al. TNF-alpha and IL-1beta-activated human mesenchymal stromal cells increase airway epithelial wound healing in vitro via activation of the epidermal growth factor receptor. Respir Res, v. 17, p. 3, Jan 112016.

CANTO, E.; RODRIGUEZ-SANCHEZ, J. L.; VIDAL, S. Distinctive response of naive lymphocytes from cord blood to primary activation via TCR. J Leukoc Biol, v. 74, n. 6, p. 998-1007, Dec 2003.

CAVALIERE, F.; DONNO, C.; D'AMBROSI, N. Purinergic signaling: a common pathway for neural and mesenchymal stem cell maintenance and differentiation. Front Cell Neurosci, v. 9, p. 211, 2015.

CHALMIN, F. et al. Stat3 and Gfi-1 transcription factors control Th17 cell immunosuppressive activity via the regulation of ectonucleotidase expression. Immunity, v. 36, n. 3, p. 362-73, Mar 232012. 
CHAPLIN, D. D. Overview of the immune response. J Allergy Clin Immunol, v. 125, n. 2 Suppl 2, p. S3-23, Feb 2010.

CHEN, M. L. et al. Latency-associated peptide identifies a novel CD4+CD25+ regulatory $\mathrm{T}$ cell subset with TGFbeta-mediated function and enhanced suppression of experimental autoimmune encephalomyelitis. $\mathbf{J}$ Immunol, $\mathbf{v}$. 180, n. 11, p. 7327-37, Jun 12008.

CHEN, W. et al. Conversion of peripheral CD4+CD25- naive $T$ cells to CD4+CD25+ regulatory $T$ cells by TGF-beta induction of transcription factor Foxp3. J Exp Med, v. 198, n. 12, p. 1875-86, Dec 152003.

CHEN, X. et al. Cutting edge: expression of TNFR2 defines a maximally suppressive subset of mouse CD4+CD25+FoxP3+ $\mathrm{T}$ regulatory cells: applicability to tumor-infiltrating $T$ regulatory cells. $\mathbf{J}$ Immunol, v. 180 , n. 10, p. 6467-71, May 152008.

CHENG, Y.; PRUSOFF, W. H. Relationship between the inhibition constant (K1) and the concentration of inhibitor which causes 50 per cent inhibition (I50) of an enzymatic reaction. Biochem Pharmacol, v. 22, n. 23, p. 3099-108, Dec 011973.

$\mathrm{CHOI}, \mathrm{D} . \mathrm{S}$. et al. Proteomics of extracellular vesicles: Exosomes and ectosomes. Mass Spectrom Rev, v. 34, n. 4, p. 474-90, Jul-Aug 2015.

COHEN, S. B. et al. The immunological properties of cord blood: overview of current research presented at the 2nd EUROCORD workshop. Bone Marrow Transplant, v. 22 Suppl 1, p. S22-5, Jul 1998.

COVAS, D. T. et al. Multipotent mesenchymal stromal cells obtained from diverse human tissues share functional properties and gene-expression profile with CD146+ perivascular cells and fibroblasts. Exp Hematol, v. 36, n. 5, p. 642-54, May 2008.

CRONSTEIN, B. N.; SITKOVSKY, M. Adenosine and adenosine receptors in the pathogenesis and treatment of rheumatic diseases. Nat Rev Rheumatol, v. 13, n. 1, p. 41-51, Jan 2017.

CUROTTO DE LAFAILLE, M. A. et al. Adaptive Foxp3+ regulatory T celldependent and -independent control of allergic inflammation. Immunity, v. 29, n. 1, p. 114-26, Jul 182008. 
DEAGLIO, S. et al. Adenosine generation catalyzed by CD39 and CD73 expressed on regulatory $T$ cells mediates immune suppression. J Exp Med, v. 204, n. 6, p. 1257-65, Jun 112007.

DERBINSKI, J. et al. Promiscuous gene expression in medullary thymic epithelial cells mirrors the peripheral self. Nat Immunol, v. 2, n. 11, p. 1032-9, Nov 2001.

DONG, R. P. et al. Characterization of adenosine deaminase binding to human CD26 on T cells and its biologic role in immune response. J Immunol, v. 156, n. 4, p. 1349-55, Feb 151996.

DWYER, K. M. et al. Expression of CD39 by human peripheral blood CD4+ CD25+ $T$ cells denotes a regulatory memory phenotype. Am J Transplant, $v$. 10, n. 11, p. 2410-20, Nov 2010.

EHRENTRAUT, $\mathrm{H}$. et al. Adora2b adenosine receptor engagement enhances regulatory $T$ cell abundance during endotoxin-induced pulmonary inflammation. PLoS One, v. 7, n. 2, p. e32416, 2012.

ELTZSCHIG, H. K. et al. Coordinated adenine nucleotide phosphohydrolysis and nucleoside signaling in posthypoxic endothelium: role of ectonucleotidases and adenosine A2B receptors. J Exp Med, v. 198, n. 5, p. 783-96, Sep 01 2003.

ENGLISH, K. Mechanisms of mesenchymal stromal cell immunomodulation. Immunol Cell Biol, v. 91, n. 1, p. 19-26, Jan 2013.

FANTINI, M. C. et al. Cutting edge: TGF-beta induces a regulatory phenotype in CD4+CD25- T cells through Foxp3 induction and down-regulation of Smad7. J Immunol, v. 172, n. 9, p. 5149-53, May 12004.

FEUERER, M. et al. Foxp3+ regulatory T cells: differentiation, specification, subphenotypes. Nat Immunol, v. 10, n. 7, p. 689-95, Jul 2009.

FINETTI, F.; CASSIOLI, C.; BALDARI, C. T. Transcellular communication at the immunological synapse: a vesicular traffic-mediated mutual exchange. F1000Res, v. 6, p. 1880, 2017.

FOMINA, A. F. et al. Regulation of membrane trafficking and subcellular organization of endocytic compartments revealed with FM1-43 in resting and activated human T cells. Exp Cell Res, v. 291, n. 1, p. 150-66, Nov 152003. 
FONTENOT, J. D. et al. Regulatory T cell lineage specification by the forkhead transcription factor foxp3. Immunity, v. 22, n. 3, p. 329-41, Mar 2005.

FRANCO, R. et al. Enzymatic and extraenzymatic role of ecto-adenosine deaminase in lymphocytes. Immunol Rev, v. 161, p. 27-42, Feb 1998.

FREDHOLM, B. B. et al. International Union of Basic and Clinical Pharmacology. LXXXI. Nomenclature and classification of adenosine receptors-an update. Pharmacol Rev, v. 63, n. 1, p. 1-34, Mar 2011.

GAVIN, M. A. et al. Foxp3-dependent programme of regulatory T-cell differentiation. Nature, v. 445, n. 7129, p. 771-5, Feb 152007.

GORINI, S.; LA SALA, A. Hydrolysis of extracellular ATP and immune suppression: humans versus mice. Blood, v. 111, n. 2, p. 964-5; author reply 965-6, Jan 152008.

GREEN, E. A. et al. CD4+CD25+ T regulatory cells control anti-islet CD8+ T cells through TGF-beta-TGF-beta receptor interactions in type 1 diabetes. Proc Natl Acad Sci U S A, v. 100, n. 19, p. 10878-83, Sep 162003.

GROHMANN, U. et al. CTLA-4-Ig regulates tryptophan catabolism in vivo. Nat Immunol, v. 3, n. 11, p. 1097-101, Nov 2002.

GROSSMAN, W. J. et al. Differential expression of granzymes A and B in human cytotoxic lymphocyte subsets and T regulatory cells. Blood, v. 104, n. 9, p. 2840-8, Nov 12004.

GU, J. et al. Human CD39(hi) regulatory $T$ cells present stronger stability and function under inflammatory conditions. Cell Mol Immunol, v. 14, n. 6, p. 521528, Jun 2017.

HADDAD, R.; SALDANHA-ARAUJO, F. Mechanisms of T-cell immunosuppression by mesenchymal stromal cells: what do we know so far? Biomed Res Int, v. 2014, p. 216806, 2014.

HARIBHAI, D. et al. A requisite role for induced regulatory $T$ cells in tolerance based on expanding antigen receptor diversity. Immunity, v. 35, n. 1, p. 10922, Jul 222011. 
HARRINGTON, L. E. et al. Interleukin 17-producing CD4+ effector T cells develop via a lineage distinct from the $T$ helper type 1 and 2 lineages. Nat Immunol, v. 6, n. 11, p. 1123-32, Nov 2005.

HASKO, G. et al. Adenosine receptors: therapeutic aspects for inflammatory and immune diseases. Nat Rev Drug Discov, v. 7, n. 9, p. 759-70, Sep 2008.

HAXHINASTO, S.; MATHIS, D.; BENOIST, C. The AKT-mTOR axis regulates de novo differentiation of CD4+Foxp3+ cells. J Exp Med, v. 205, n. 3, p. 56574, Mar 172008.

HOGQUIST, K. A.; JAMESON, S. C. The self-obsession of T cells: how TCR signaling thresholds affect fate 'decisions' and effector function. Nat Immunol, v. 15, n. 9, p. 815-23, Sep 2014.

HORI, S.; SAKAGUCHI, S. Foxp3: a critical regulator of the development and function of regulatory T cells. Microbes Infect, v. 6, n. 8, p. 745-51, Jul 2004.

HORWITZ, D. A.; ZHENG, S. G.; GRAY, J. D. The role of the combination of IL2 and TGF-beta or IL-10 in the generation and function of CD4+ CD25+ and CD8+ regulatory T cell subsets. J Leukoc Biol, v. 74, n. 4, p. 471-8, Oct 2003.

HSIEH, C. S.; LEE, H. M.; LIO, C. W. Selection of regulatory T cells in the thymus. Nat Rev Immunol, v. 12, n. 3, p. 157-67, Feb 102012.

HSIEH, C. S. et al. An intersection between the self-reactive regulatory and nonregulatory $\mathrm{T}$ cell receptor repertoires. Nat Immunol, v. 7, n. 4, p. 401-10, Apr 2006.

HUBERT, F. X. et al. Aire regulates the transfer of antigen from mTECs to dendritic cells for induction of thymic tolerance. Blood, v. 118, n. 9, p. 2462-72, Sep 12011.

JACOBSON, K. A.; GAO, Z. G. Adenosine receptors as therapeutic targets. Nat Rev Drug Discov, v. 5, n. 3, p. 247-64, Mar 2006.

JANEWAY, C. A., JR.; MEDZHITOV, R. Innate immune recognition. Annu Rev Immunol, v. 20, p. 197-216, 2002.

JORDAN, M. S. et al. Thymic selection of CD4+CD25+ regulatory $T$ cells induced by an agonist self-peptide. Nat Immunol, v. 2, n. 4, p. 301-6, Apr 2001. 
JUNGER, W. G. Immune cell regulation by autocrine purinergic signalling. Nat Rev Immunol, v. 11, n. 3, p. 201-12, Mar 2011.

KALEKAR, L. A.; MUELLER, D. L. Relationship between CD4 Regulatory T Cells and Anergy In Vivo. J Immunol, v. 198, n. 7, p. 2527-2533, Apr 12017.

KANAMORI, M. et al. Induced Regulatory T Cells: Their Development, Stability, and Applications. Trends Immunol, v. 37, n. 11, p. 803-811, Nov 2016.

KANG, J. et al. De novo induction of antigen-specific CD4+CD25+Foxp3+ regulatory $T$ cells in vivo following systemic antigen administration accompanied by blockade of mTOR. J Leukoc Biol, v. 83, n. 5, p. 1230-9, May 2008.

KERKELA, E. Response to Letter to the Editor: Adenosine Producing Mesenchymal Stromal Cells. Stem Cells, Nov 112016.

Reply: Adenosine Producing Mesenchymal Stromal Cells. Stem Cells, v. 35, n. 6, p. 1649-1650, Jun 2017.

KERKELA, E. et al. Adenosinergic Immunosuppression by Human Mesenchymal Stromal Cells Requires Co-Operation with T cells. Stem Cells, v. 34, n. 3, p. 781-90, Mar 2016.

KILPINEN, L. et al. Extracellular membrane vesicles from umbilical cord bloodderived MSC protect against ischemic acute kidney injury, a feature that is lost after inflammatory conditioning. J Extracell Vesicles, v. 2, 2013.

KISS, A. L.; KITTEL, A. Early endocytotic steps in elicited macrophages: omega-shaped plasma membrane vesicles at their cell surface. Cell Biol Int, v. 19, n. 6, p. 527-38, Jun 1995.

KITTEL, A. et al. CD39 as a caveolar-associated ectonucleotidase. Biochem Biophys Res Commun, v. 262, n. 3, p. 596-9, Sep 071999.

KLEIN, L. et al. Positive and negative selection of the $T$ cell repertoire: what thymocytes see (and don't see). Nat Rev Immunol, v. 14, n. 6, p. 377-91, Jun 2014.

KLOTZ, K. N. et al. Comparative pharmacology of human adenosine receptor subtypes - characterization of stably transfected receptors in $\mathrm{CHO}$ cells. Naunyn Schmiedebergs Arch Pharmacol, v. 357, n. 1, p. 1-9, Jan 1998. 
KOBIE, J. J. et al. T regulatory and primed uncommitted CD4 T cells express CD73, which suppresses effector CD4 T cells by converting 5'-adenosine monophosphate to adenosine. J Immunol, v. 177, n. 10, p. 6780-6, Nov 15 2006.

KONO, H.; ROCK, K. L. How dying cells alert the immune system to danger. Nat Rev Immunol, v. 8, n. 4, p. 279-89, Apr 2008.

KOPF, $\mathrm{H}$. et al. Rapamycin inhibits differentiation of Th17 cells and promotes generation of FoxP3+ T regulatory cells. Int Immunopharmacol, v. 7, n. 13, p. 1819-24, Dec 152007.

$\mathrm{KOVACH}, \mathrm{T} . \mathrm{K}$. et al. Interactions between MSCs and immune cells: implications for bone healing. J Immunol Res, v. 2015, p. 752510, 2015.

KOZIAK, K. et al. Palmitoylation targets CD39/endothelial ATP diphosphohydrolase to caveolae. J Biol Chem, v. 275, n. 3, p. 2057-62, Jan 21 2000.

KUHN, K. A.; STAPPENBECK, T. S. Peripheral education of the immune system by the colonic microbiota. Semin Immunol, v. 25, n. 5, p. 364-9, Nov 30 2013.

$\mathrm{LAL}, \mathrm{G}$. et al. Epigenetic regulation of Foxp3 expression in regulatory $\mathrm{T}$ cells by DNA methylation. J Immunol, v. 182, n. 1, p. 259-73, Jan 12009.

LATHROP, S. K. et al. Peripheral education of the immune system by colonic commensal microbiota. Nature, v. 478, n. 7368, p. 250-4, Sep 212011.

LEE, P. P. et al. A critical role for Dnmt1 and DNA methylation in T cell development, function, and survival. Immunity, v. 15, n. 5, p. 763-74, Nov 2001.

LERRER, S. et al. Co-Inflammatory Roles of TGFbeta1 in the Presence of TNFalpha Drive a Pro-inflammatory Fate in Mesenchymal Stem Cells. Front Immunol, v. 8, p. 479, 2017.

LI, L. et al. CD4+CD25+ regulatory T-cell lines from human cord blood have functional and molecular properties of T-cell anergy. Blood, v. 106, n. 9, p. 3068-73, Nov 12005. 
LIU, J. et al. T regulatory cells in cord blood--FOXP3 demethylation as reliable quantitative marker. PLoS One, v. 5, n. 10, p. e13267, 2010.

LIU, W. et al. CD127 expression inversely correlates with FoxP3 and suppressive function of human CD4+ $T$ reg cells. J Exp Med, v. 203, n. 7, p. 1701-11, Jul 102006.

LONG, S. A.; BUCKNER, J. H. CD4+FOXP3+ T regulatory cells in human autoimmunity: more than a numbers game. J Immunol, v. 187, n. 5, p. 2061-6, Sep 12011.

LV, F. J. et al. Concise review: the surface markers and identity of human mesenchymal stem cells. Stem Cells, v. 32, n. 6, p. 1408-19, Jun 2014.

MACCARIO, R. et al. Interaction of human mesenchymal stem cells with cells involved in alloantigen-specific immune response favors the differentiation of CD4+ T-cell subsets expressing a regulatory/suppressive phenotype. Haematologica, v. 90, n. 4, p. 516-25, Apr 2005.

MAHIC, M. et al. Differentiation of naive CD4+ $T$ cells into CD4+CD25+FOXP3+ regulatory $T$ cells by continuous antigen stimulation. $\mathbf{J}$ Leukoc Biol, v. 83, n. 5, p. 1111-7, May 2008.

MALCHOW, S. et al. Aire-dependent thymic development of tumor-associated regulatory T cells. Science, v. 339, n. 6124, p. 1219-24, Mar 82013.

MANDAPATHIL, M. et al. Generation and accumulation of immunosuppressive adenosine by human CD4+CD25highFOXP3+ regulatory T cells. J Biol Chem, v. 285, n. 10, p. 7176-86, Mar 52010.

MANDAPATHIL, M. et al. Isolation of functional human regulatory T cells (Treg) from the peripheral blood based on the CD39 expression. $\mathbf{J}$ Immunol Methods, v. 346, n. 1-2, p. 55-63, Jul 312009.

MANDAPATHIL, M. et al. Adenosine and prostaglandin E2 cooperate in the suppression of immune responses mediated by adaptive regulatory $T$ cells. $\mathbf{J}$ Biol Chem, v. 285, n. 36, p. 27571-80, Sep 32010.

MAREK-TRZONKOWSKA, N. et al. Administration of CD4+CD25highCD127regulatory $T$ cells preserves beta-cell function in type 1 diabetes in children. Diabetes Care, v. 35, n. 9, p. 1817-20, Sep 2012. 
MARTIN, F.; APETOH, L.; GHIRINGHELLI, F. Controversies on the role of Th17 in cancer: a TGF-beta-dependent immunosuppressive activity? Trends Mol Med, v. 18, n. 12, p. 742-9, Dec 2012.

MAYER, E. et al. Cord blood derived CD4+ CD25(high) T cells become functional regulatory $T$ cells upon antigen encounter. PLoS One, v. 7, n. 1, p. e29355, 2012.

MCHUGH, R. S. et al. CD4(+)CD25(+) immunoregulatory T cells: gene expression analysis reveals a functional role for the glucocorticoid-induced TNF receptor. Immunity, v. 16, n. 2, p. 311-23, Feb 2002.

MELLANBY, R. J.; THOMAS, D. C.; LAMB, J. Role of regulatory T-cells in autoimmunity. Clin Sci (Lond), v. 116, n. 8, p. 639-49, Apr 2009.

MORAN, A. E. et al. T cell receptor signal strength in Treg and iNKT cell development demonstrated by a novel fluorescent reporter mouse. J Exp Med, v. 208, n. 6, p. 1279-89, Jun 62011.

NAJAR, M. et al. Insights into inflammatory priming of mesenchymal stromal cells: functional biological impacts. Inflamm Res, Jan 232018.

NAKATSUKASA, $\mathrm{H}$. et al. Adenosine A2B receptor antagonist suppresses differentiation to regulatory $\mathrm{T}$ cells without suppressing activation of $\mathrm{T}$ cells. Biochem Biophys Res Commun, v. 409, n. 1, p. 114-9, May 272011.

NEMAZEE, D. Receptor selection in B and T lymphocytes. Annu Rev Immunol, v. 18, p. 19-51, 2000.

NEUBIG, R. R. et al. International Union of Pharmacology Committee on Receptor Nomenclature and Drug Classification. XXXVIII. Update on terms and symbols in quantitative pharmacology. Pharmacol Rev, v. 55, n. 4, p. 597-606, Dec 2003.

NISHIKAWA, H.; SAKAGUCHI, S. Regulatory T cells in tumor immunity. Int $\mathbf{J}$ Cancer, v. 127, n. 4, p. 759-67, Aug 152010.

NOWARSKI, R.; JACKSON, R.; FLAVELL, R. A. The Stromal Intervention: Regulation of Immunity and Inflammation at the Epithelial-Mesenchymal Barrier. Cell, v. 168, n. 3, p. 362-375, Jan 262017. 
O'GARRA, A.; MURPHY, K. Role of cytokines in determining T-lymphocyte function. Curr Opin Immunol, v. 6, n. 3, p. 458-66, Jun 1994.

OHTA, A. et al. The development and immunosuppressive functions of CD4(+) CD25(+) FoxP3(+) regulatory T cells are under influence of the adenosine-A2A adenosine receptor pathway. Front Immunol, v. 3, p. 190, 2012.

OHTSUKA, T. et al. Ecto-5'-nucleotidase (CD73) attenuates allograft airway rejection through adenosine $2 \mathrm{~A}$ receptor stimulation. J Immunol, v. 185, n. 2, p. 1321-9, Jul 152010.

OLAH, M. E.; STILES, G. L. Adenosine receptor subtypes: characterization and therapeutic regulation. Annu Rev Pharmacol Toxicol, v. 35, p. 581-606, 1995.

PANDIYAN, P. et al. CD4+CD25+Foxp3+ regulatory $T$ cells induce cytokine deprivation-mediated apoptosis of effector CD4+ T cells. Nat Immunol, v. 8, n. 12, p. 1353-62, Dec 2007.

PANEPUCCI, R. A. et al. Comparison of gene expression of umbilical cord vein and bone marrow-derived mesenchymal stem cells. Stem Cells, v. 22, n. 7, p. 1263-78, 2004.

PANTHER, E. et al. AMP affects intracellular $\mathrm{Ca} 2+$ signaling, migration, cytokine secretion and T cell priming capacity of dendritic cells. PLoS One, v. 7, n. 5, p. e37560, 2012.

POLCHERT, D. et al. IFN-gamma activation of mesenchymal stem cells for treatment and prevention of graft versus host disease. Eur $\mathbf{J}$ Immunol, v. 38, n. 6, p. 1745-55, Jun 2008.

PREVOSTO, C. et al. Generation of CD4+ or CD8+ regulatory T cells upon mesenchymal stem cell-lymphocyte interaction. Haematologica, v. 92, n. 7, p. 881-8, Jul 2007.

READ, S.; MALMSTROM, V.; POWRIE, F. Cytotoxic T lymphocyte-associated antigen 4 plays an essential role in the function of $\mathrm{CD} 25(+) \mathrm{CD} 4(+)$ regulatory cells that control intestinal inflammation. J Exp Med, v. 192, n. 2, p. 295-302, Jul 172000.

REDMOND, W. L.; SHERMAN, L. A. Peripheral tolerance of CD8 T lymphocytes. Immunity, v. 22, n. 3, p. 275-84, Mar 2005. 
RESTA, R.; YAMASHITA, Y.; THOMPSON, L. F. Ecto-enzyme and signaling functions of lymphocyte CD73. Immunol Rev, v. 161, p. 95-109, Feb 1998.

RITTINER, J. E. et al. AMP is an adenosine A1 receptor agonist. J Biol Chem, v. 287, n. 8, p. 5301-9, Feb 172012.

ROMAGNANI, S. et al. Properties and origin of human Th17 cells. Mol Immunol, v. 47, n. 1, p. 3-7, Nov 2009.

RONCAROLO, M. G.; BATTAGLIA, M. Regulatory T-cell immunotherapy for tolerance to self antigens and alloantigens in humans. Nat Rev Immunol, v. 7, n. 8, p. 585-98, Aug 2007.

SAKAGUCHI, S. et al. Foxp3+ CD25+ CD4+ natural regulatory $\mathrm{T}$ cells in dominant self-tolerance and autoimmune disease. Immunol Rev, v. 212, p. 827, Aug 2006.

SAKAGUCHI, S. et al. Immunologic self-tolerance maintained by activated T cells expressing IL-2 receptor alpha-chains (CD25). Breakdown of a single mechanism of self-tolerance causes various autoimmune diseases. J Immunol, v. 155, n. 3, p. 1151-64, Aug 11995.

SAKAGUCHI, S. et al. Regulatory T cells and immune tolerance. Cell, v. 133, n. 5, p. 775-87, May 302008.

SALDANHA-ARAUJO, F. et al. Mesenchymal stromal cells up-regulate CD39 and increase adenosine production to suppress activated T-lymphocytes. Stem Cell Res, v. 7, n. 1, p. 66-74, Jul 2011.

SALDANHA-ARAUJO, F. et al. Mesenchymal stem cells promote the sustained expression of CD69 on activated T lymphocytes: roles of canonical and noncanonical NF-kappaB signalling. J Cell Mol Med, v. 16, n. 6, p. 1232-44, Jun 2012.

SALDANHA-ARAUJO, $F$. et al. Mesenchymal stem cells promote the sustained expression of CD69 on activated T lymphocytes: roles of canonical and noncanonical NF-kappa B signalling. Journal of Cellular and Molecular Medicine, v. 16, n. 6, p. 1232-1244, JUN 20122012.

SALDANHA-ARAUJO, F.; PANEPUCCI, R. A. CD39 expression in mesenchymal stromal cells. J Immunother, v. 34, n. 7, p. 568, Sep 2011. 
SALOMON, B. et al. B7/CD28 costimulation is essential for the homeostasis of the CD4+CD25+ immunoregulatory $\mathrm{T}$ cells that control autoimmune diabetes. Immunity, v. 12, n. 4, p. 431-40, Apr 2000.

SAMSONRAJ, R. M. et al. Concise Review: Multifaceted Characterization of Human Mesenchymal Stem Cells for Use in Regenerative Medicine. Stem Cells TransI Med, Oct 262017.

SAMSTEIN, R. M. et al. Extrathymic generation of regulatory $\mathrm{T}$ cells in placental mammals mitigates maternal-fetal conflict. Cell, v. 150, n. 1, p. 29-38, Jul 62012.

SANGIORGI, B. et al. DSP30 enhances the immunosuppressive properties of mesenchymal stromal cells and protects their suppressive potential from lipopolysaccharide effects: A potential role of adenosine. Cytotherapy, v. 18, n. 7, p. 846-59, Jul 2016.

SATTLER, C. et al. Inhibition of T-cell proliferation by murine multipotent mesenchymal stromal cells is mediated by CD39 expression and adenosine generation. Cell Transplant, v. 20, n. 8, p. 1221-30, 2011.

SAUER, S. et al. T cell receptor signaling controls Foxp3 expression via PI3K, Akt, and mTOR. Proc Natl Acad Sci U S A, v. 105, n. 22, p. 7797-802, Jun 3 2008.

SCHIAVINATO, J. et al. TGF-beta/atRA-induced Tregs express a selected set of microRNAs involved in the repression of transcripts related to Th17 differentiation. Sci Rep, v. 7, n. 1, p. 3627, Jun 152017.

SCHMITT, E. G.; WILLIAMS, C. B. Generation and function of induced regulatory T cells. Front Immunol, v. 4, p. 152, 2013.

SCHULER, P. J. et al. Separation of human CD4+CD39+ T cells by magnetic beads reveals two phenotypically and functionally different subsets. $\mathbf{J}$ Immunol Methods, v. 369, n. 1-2, p. 59-68, Jun 302011.

SCHULER, P. J. et al. Human CD4+ CD39+ regulatory T cells produce adenosine upon co-expression of surface CD73 or contact with CD73+ exosomes or CD73+ cells. Clin Exp Immunol, v. 177, n. 2, p. 531-43, Aug 2014. 
SCHULER, P. J. et al. Phenotypic and functional characteristics of CD4+ CD39+ FOXP3+ and CD4+ CD39+ FOXP3neg T-cell subsets in cancer patients. Eur J Immunol, v. 42, n. 7, p. 1876-85, Jul 2012.

SHEVACH, E. M.; THORNTON, A. M. tTregs, pTregs, and iTregs: similarities and differences. Immunol Rev, v. 259, n. 1, p. 88-102, May 2014.

SHIMIZU, J. et al. Stimulation of CD25(+)CD4(+) regulatory T cells through GITR breaks immunological self-tolerance. Nat Immunol, v. 3, n. 2, p. 135-42, Feb 2002.

SITKOVSKY, M.; LUKASHEV, D. Regulation of immune cells by local-tissue oxygen tension: HIF1 alpha and adenosine receptors. Nat Rev Immunol, v. 5, n. 9, p. 712-21, Sep 2005.

SITKOVSKY, M. V.; OHTA, A. The 'danger' sensors that STOP the immune response: the A2 adenosine receptors? Trends Immunol, v. 26, n. 6, p. 299304, Jun 2005.

SMITH-GARVIN, J. E.; KORETZKY, G. A.; JORDAN, M. S. T cell activation. Annu Rev Immunol, v. 27, p. 591-619, 2009.

SOBACCHI, C. et al. Soluble Factors on Stage to Direct Mesenchymal Stem Cells Fate. Front Bioeng Biotechnol, v. 5, p. 32, 2017.

SODERBACK, U.; SOLLEVI, A.; FREDHOLM, B. B. The disappearance of adenosine from blood and platelet suspension in relation to the platelet cyclic AMP content. Acta Physiol Scand, v. 129, n. 2, p. 189-94, Feb 1987.

TAKABA, H.; TAKAYANAGI, $H$. The Mechanisms of T Cell Selection in the Thymus. Trends Immunol, v. 38, n. 11, p. 805-816, Nov 2017.

TAKAHASHI, $T$. et al. Immunologic self-tolerance maintained by CD25(+)CD4(+) regulatory $T$ cells constitutively expressing cytotoxic $T$ lymphocyte-associated antigen 4. J Exp Med, v. 192, n. 2, p. 303-10, Jul 17 2000.

TANG, Q.; BLUESTONE, J. A. The Foxp3+ regulatory T cell: a jack of all trades, master of regulation. Nat Immunol, v. 9, n. 3, p. 239-44, Mar 2008.

THIEL, M.; CALDWELL, C. C.; SITKOVSKY, M. V. The critical role of adenosine A2A receptors in downregulation of inflammation and immunity in the 
pathogenesis of infectious diseases. Microbes Infect, v. 5, n. 6, p. 515-26, May 2003.

THOMSON, L. F. et al. Production and characterization of monoclonal antibodies to the glycosyl phosphatidylinositol-anchored lymphocyte differentiation antigen ecto-5'-nucleotidase (CD73). Tissue Antigens, v. 35, n. 1, p. 9-19, Jan 1990.

TUMNE, A. et al. Noncytotoxic suppression of human immunodeficiency virus type 1 transcription by exosomes secreted from CD8+ T cells. J Virol, v. 83, n. 9, p. 4354-64, May 2009.

TURVEY, S. E.; BROIDE, D. H. Innate immunity. J Allergy Clin Immunol, v. 125, n. 2 Suppl 2, p. S24-32, Feb 2010.

WATERMAN, R. S. et al. A new mesenchymal stem cell (MSC) paradigm: polarization into a pro-inflammatory MSC1 or an Immunosuppressive MSC2 phenotype. PLoS One, v. 5, n. 4, p. e10088, Apr 262010.

WEINMANN, A. S. Roles for helper $T$ cell lineage-specifying transcription factors in cellular specialization. Adv Immunol, v. 124, p. 171-206, 2014.

WORKMAN, C. J. et al. The development and function of regulatory $\mathrm{T}$ cells. Cell Mol Life Sci, v. 66, n. 16, p. 2603-22, Aug 2009.

$\mathrm{XIE}, \mathrm{J}$. et al. cAMP inhibits mammalian target of rapamycin complex-1 and -2 (mTORC1 and 2) by promoting complex dissociation and inhibiting mTOR kinase activity. Cellular Signalling, v. 23, n. 12, p. 1927-1935, 2011.

YADAV, M.; STEPHAN, S.; BLUESTONE, J. A. Peripherally induced tregs - role in immune homeostasis and autoimmunity. Front Immunol, v. 4, p. 232, 2013.

YAGI, $\mathrm{H}$. et al. Crucial role of FOXP3 in the development and function of human CD25+CD4+ regulatory T cells. Int Immunol, v. 16, n. 11, p. 1643-56, Nov 2004.

YAN, L. et al. Adenosine receptor agonists: from basic medicinal chemistry to clinical development. Expert Opin Emerg Drugs, v. 8, n. 2, p. 537-76, Nov 2003. 
ZAREK, P. E. et al. A2A receptor signaling promotes peripheral tolerance by inducing $\mathrm{T}$-cell anergy and the generation of adaptive regulatory $\mathrm{T}$ cells. Blood, v. 111, n. 1, p. 251-9, Jan 12008.

ZEISER, R. et al. Differential impact of mammalian target of rapamycin inhibition on CD4+CD25+Foxp3+ regulatory T cells compared with conventional CD4+ T cells. Blood, v. 111, n. 1, p. 453-62, Jan 12008.

ZHOU, L.; CHONG, M. M.; LITTMAN, D. R. Plasticity of CD4+ T cell lineage differentiation. Immunity, v. 30, n. 5, p. 646-55, May 2009.

ZHOU, Q. et al. Isolated CD39 expression on CD4+ T cells denotes both regulatory and memory populations. Am J Transplant, v. 9, n. 10, p. 2303-11, Oct 2009.

ZIMMERMANN, H.; ZEBISCH, M.; STRATER, N. Cellular function and molecular structure of ecto-nucleotidases. Purinergic Signal, v. 8, n. 3, p. 437502, Sep 2012.

ZOU, W.; RESTIFO, N. P. T(H)17 cells in tumour immunity and immunotherapy. Nat Rev Immunol, v. 10, n. 4, p. 248-56, Apr 2010. 


\section{6- APÊNDICES}




\section{Apêndices Capítulo I}

\section{Efeitos tóxicos e inespecíficos do DMSO}

O primeiro intuito foi de avaliarmos o efeito da sinalização de adenosina sobre o processo de geração de células Treg, analizando a morte celular e a própria geração de células Treg CD4+CD25+CD127-. Para isso, utilizamos diferentes concentrações de NECA, um análogo sintético da adenosina e agonista genérico de seus receptores, comparando-as a condições controle sem droga, mas, contendo a mesma concentração do excipiente DMSO. Após ativadas e cultivadas por 5 dias, em condições adequadas para a geração de Tregs, as células foram incubadas com o corante de DNA iodeto de propídio (PI) para marcação das células mortas (com a membrana danificada e permeável ao $\mathrm{Pl}$ ). As imagens destes ensaios foram adquiridas utilizando dois diferentes canais de fluorescência: o DAPI (para a visualização de todos os núcleos, corados com Hoechst 33342) e o Cy3 (para vizualização dos núcleos de células mortas, marcadas com $\mathrm{PI}$ ). Os núcleos foram segmentados e contados utilizando-se a ferramenta doo módulo Multi-Wavelength Cell Scoring, baseando-se na imagem gerada pelo canal de DAPI, e as porcentagems de células vivas (núcleos PInegativos) foram calculadas (Figura a1). Em paralelo, as células foram marcadas com Hoechst e com anticorpos anti-CD4 PE, CD25 APC e CD127 FITC. Para isto, as amostras foram incubadas no próprio poço com os anticorpos contra os marcadores a serem avaliados e com os controles de isotipo adequados. Após incubação com os anticorpos pertinentes (em geladeira por $20 \mathrm{~min}$ ), o pellet de células foi ressuspendido em 100uL em PBS e a placa foi centrifugada por 5 min a $500 \mathrm{RPM}$, o sobrenadante descartado, e as células ressuspendidas em $50 \mu \mathrm{L}$ de PBS para aquisição das células pelo HCS ImageXpress XL (Molecular Devices) (Figuras a1 e a2). 


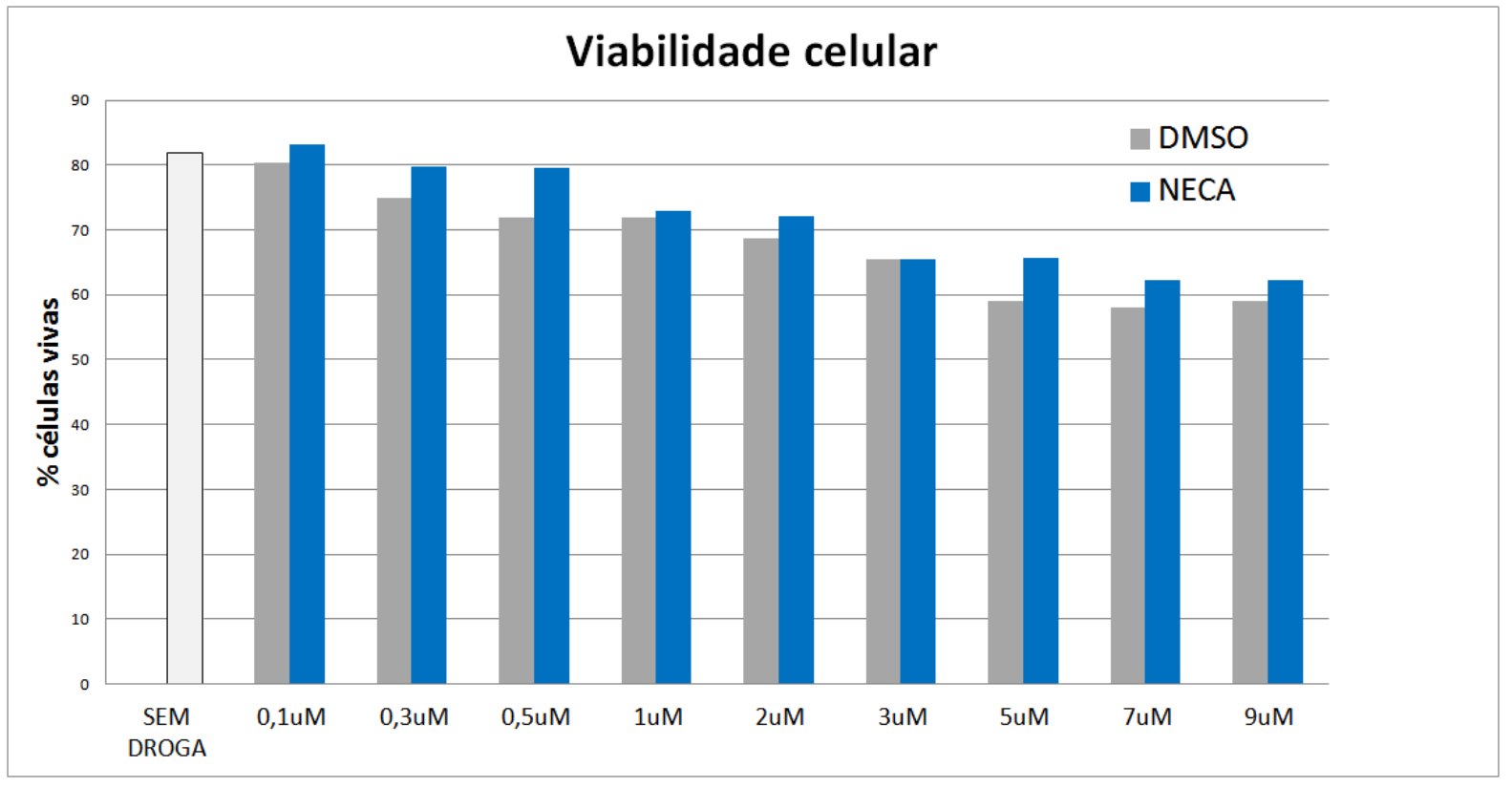

Figura a1. Representação gráfica do experimento de viabilidade celular. No gráfico, é possível visualizar as porcentagens de células viáveis tratadas com diferentes concentrações de NECA ou somente o seu veículo (DMSO). Triplicata experimental $(\mathrm{N}=1)$.

Como pode ser notado na figura a1, algumas concentrações de NECA apresentaram viabilidade superiores aos seus controles com DMSO, no entanto, fica evidente que as concentrações crescentes de DMSO (condição controle com o veículo excipiente da droga) levaram a um aumento de morte celular, causando uma redução na viabilidade celular de $80 \%$ para até $60 \%$. Adicionalmente, as concentrações crescentes de DMSO levaram a uma redução marcante na porcentagem de células Treg, com uma queda de $70 \%$ para até 30\% (Figura 6). Ainda, somente na condição controle com a menor concentração de DMSO (equivalente à quantidade de DMSO presente na concentração de $0,1 \mu \mathrm{M}$ de NECA), as percentagens de viabilidade celular e de células Treg se equipararam à condição controle sem a droga ou seu veículo excipiente. Ainda, nesta condição, o NECA causou um aumento de $10 \%$ na porcentagem de Tregs.

Esta avaliação preliminar tornou evidente que os linfócitos nestas condições de cultivo, se mostraram extremamente sensíveis ao DMSO, mesmo nas concentrações utilizadas (de $0,02 \%$ a $1,8 \%$, v/v). A fim de solucionar este problema, novas alíquotas das drogas foram preparadas utilizando como veículo excipiente o meio de cultura RPMI. Desta forma, passamos a utilizar 
porcentagens de DMSO inferiores a $0,01 \%$ (inferiores à concentração encontrada na condição de $0,1 \mu \mathrm{M}$ das figuras a1 e a2).

Papel dos receptores de adenosina na expressão de CD39 e CD73 durante a indução de linfócitos Treg

\section{Receptor A1}

A CD $4^{+}$C D $39^{+}$

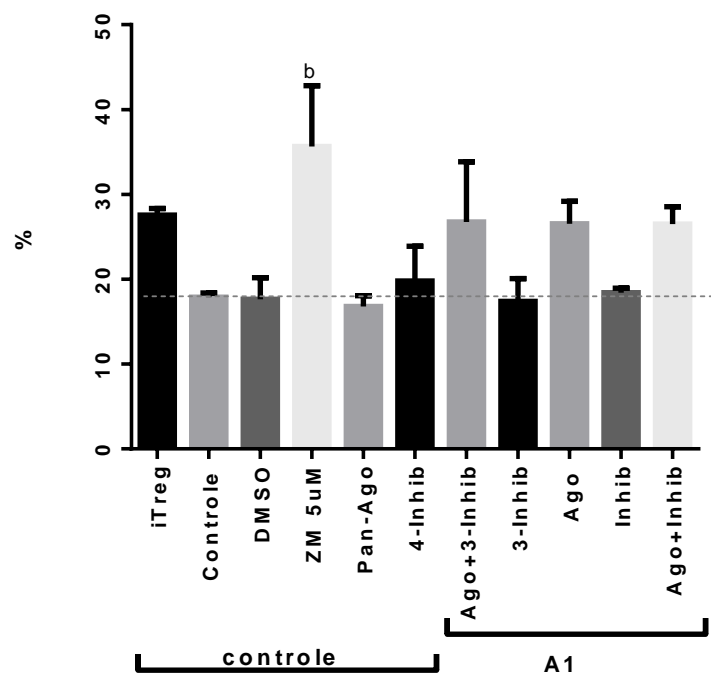

C

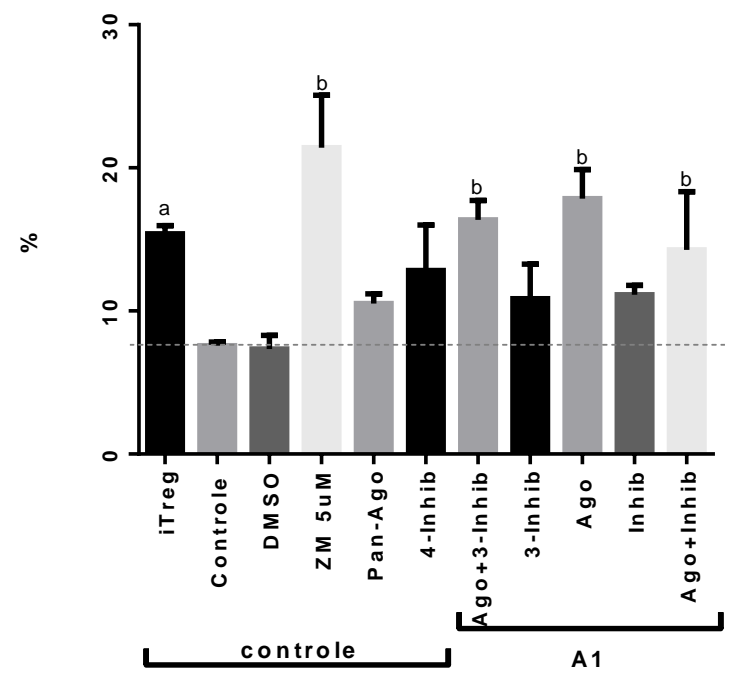

B $\mathrm{CD} 4^{+} \mathrm{CD} 73^{+}$

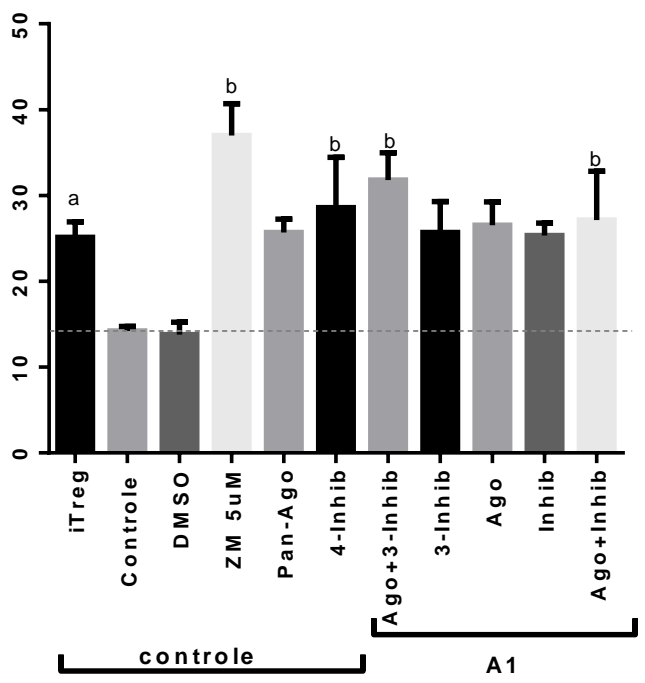

D

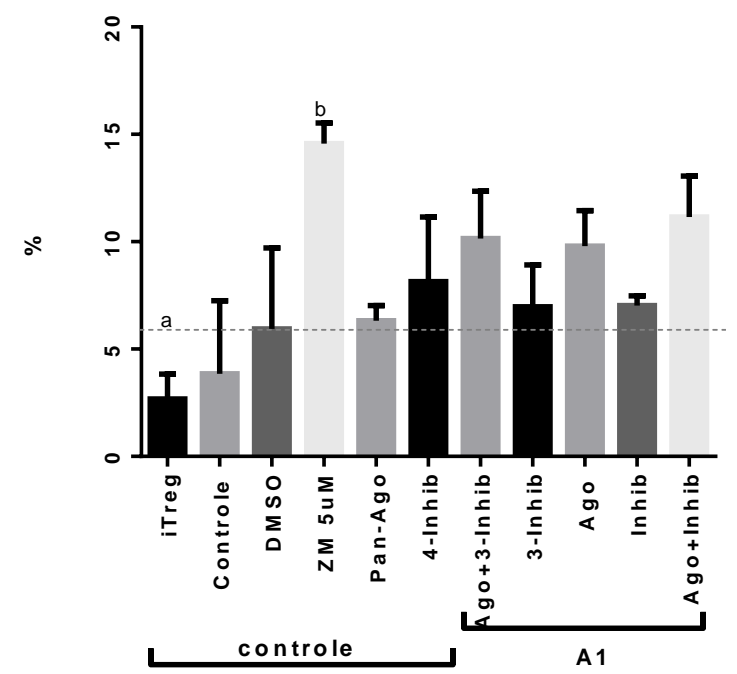

Figura a2 . Expressão média das ectonucleotidases CD39+ e CD73+. A) Porcentagem de células CD39+ na população CD4+. B) Porcentagem de células CD73+ na população CD4+. C) População CD39+CD73+ avaliada na 
população CD4+. D) População CD39+CD73+ avaliado na população CD4+CD25-. A linha tracejada demonstra a média do tratamento controle. Valores expressos como média \pm SD. One-way ANOVA, pós teste Tukey. "a" se refere a significância estatística $(p<0,05)$ entre condições iTreg versus controles; "b" se refere significância estatística $(p<0,05)$ entre a condição DMSO e todas condições contendo drogas. $\mathrm{N}=3$, duplicata experimental. 


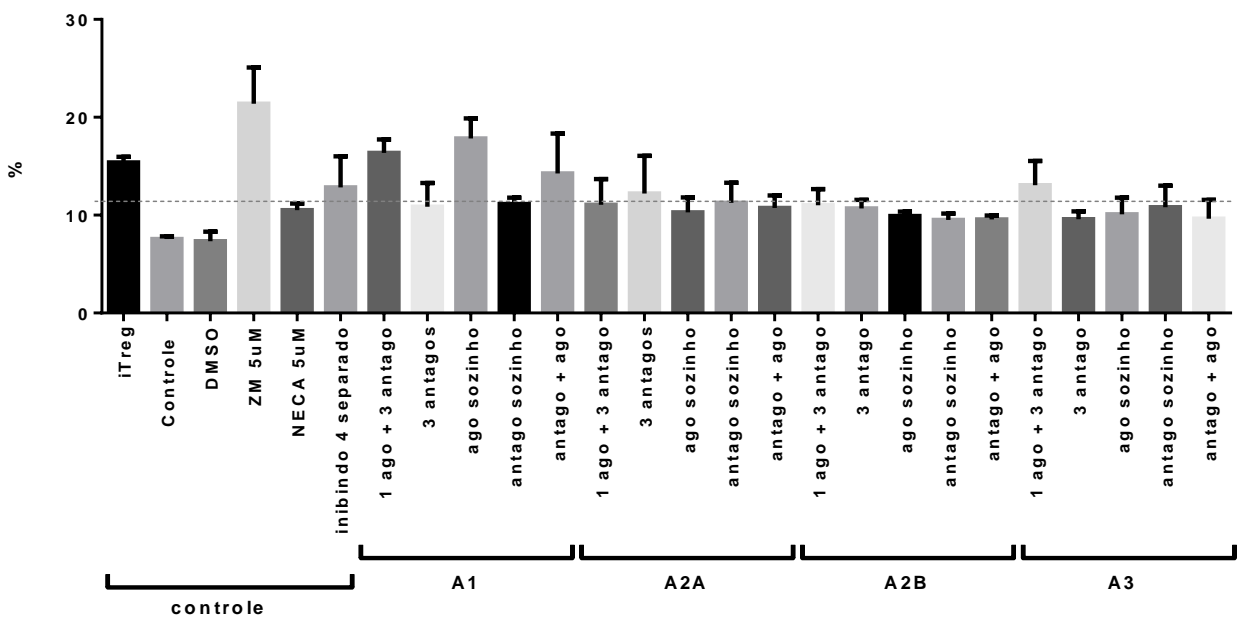

CD $4+C D 39+$

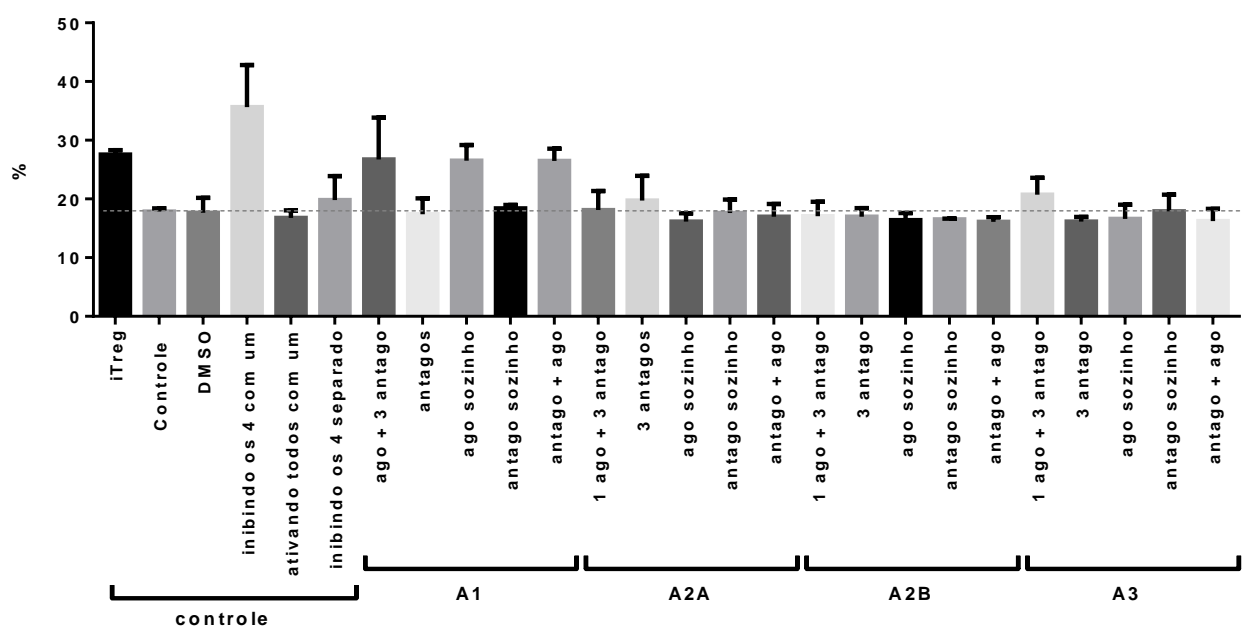

CD $4+C D 73+$

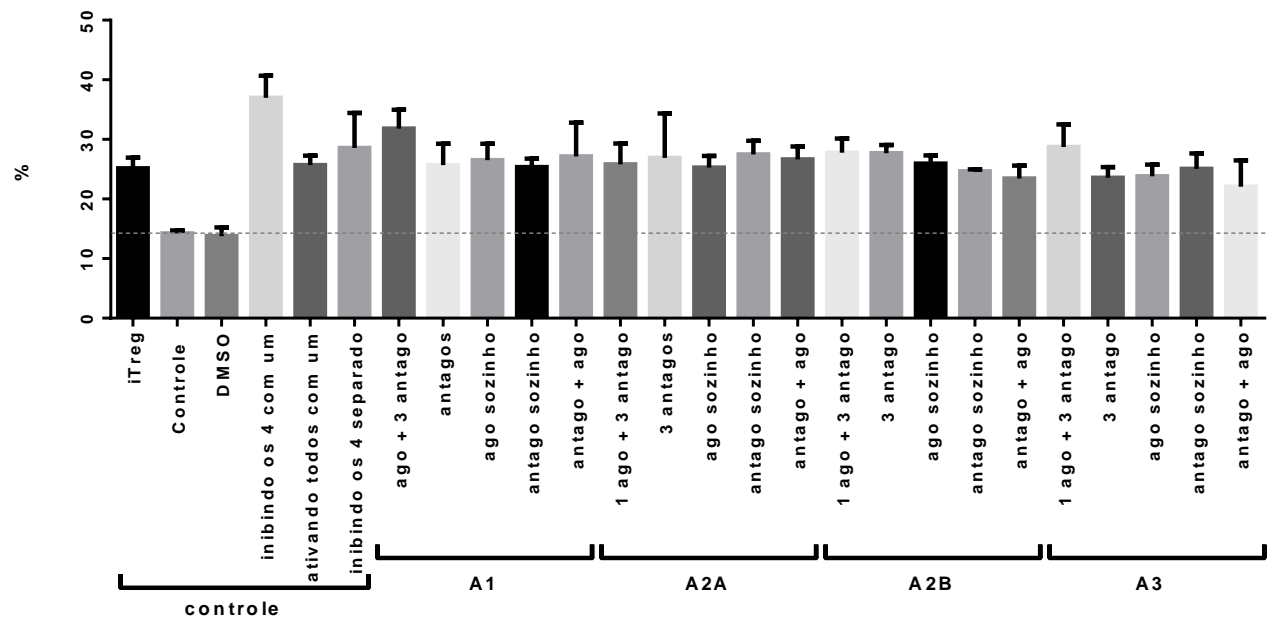

Figura a3. Sinalização de adenosina e expressão de CD39 e CD73 em linfócitos. A) População CD39+ CD73+ avaliada na população CD4+. B) Porcentagem de células CD39+ na população CD4+. C) Porcentagem de 
células CD73+ na população CD4+. D) População CD25+CD39+CD73+ avaliado na população CD4+. E) Porcentagem da população CD39+CD73+ em células CD4+CD25 negativas. Análise realizada por citometria de fluxo. 


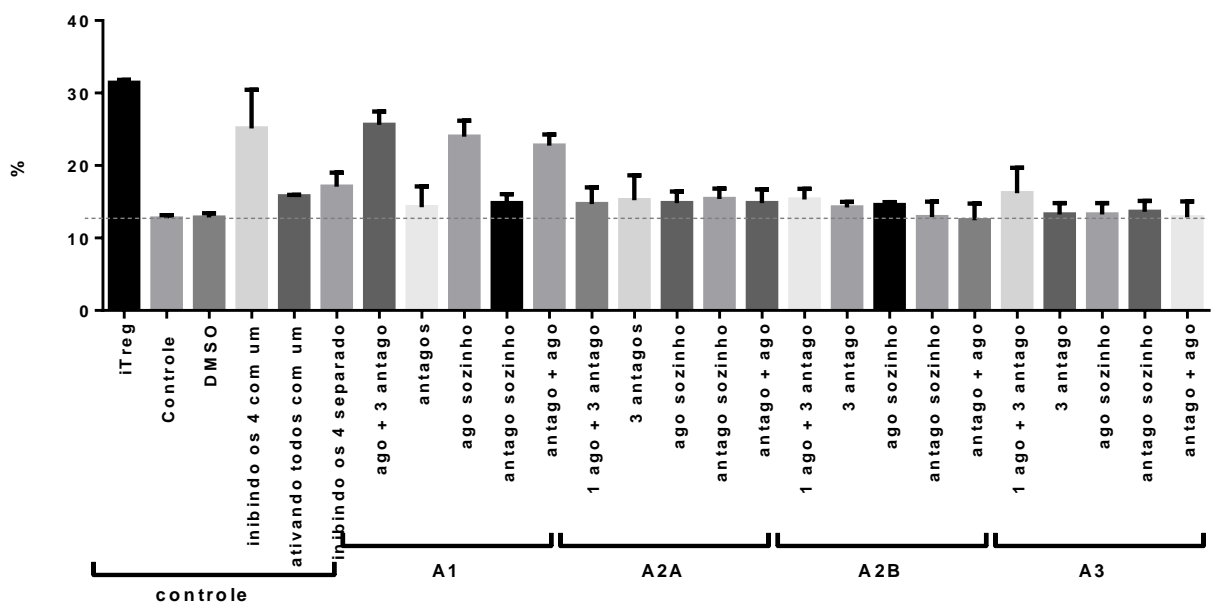

$4+C D 25+C D 39+$

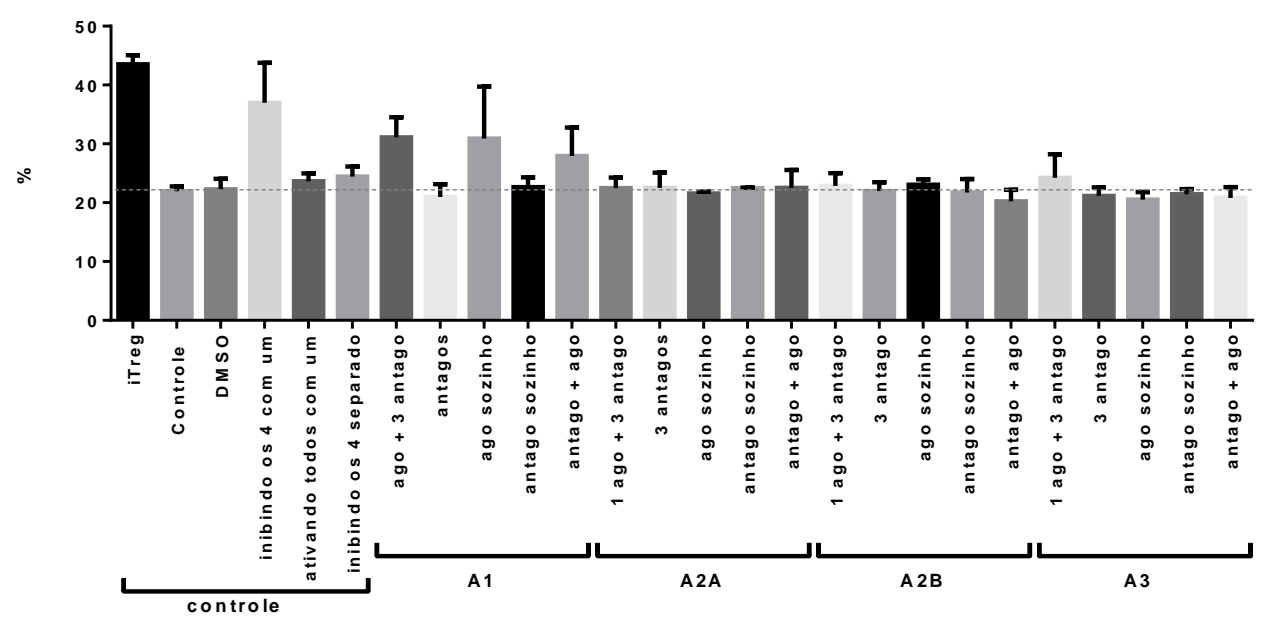

$4+C D 25+C D 73+$

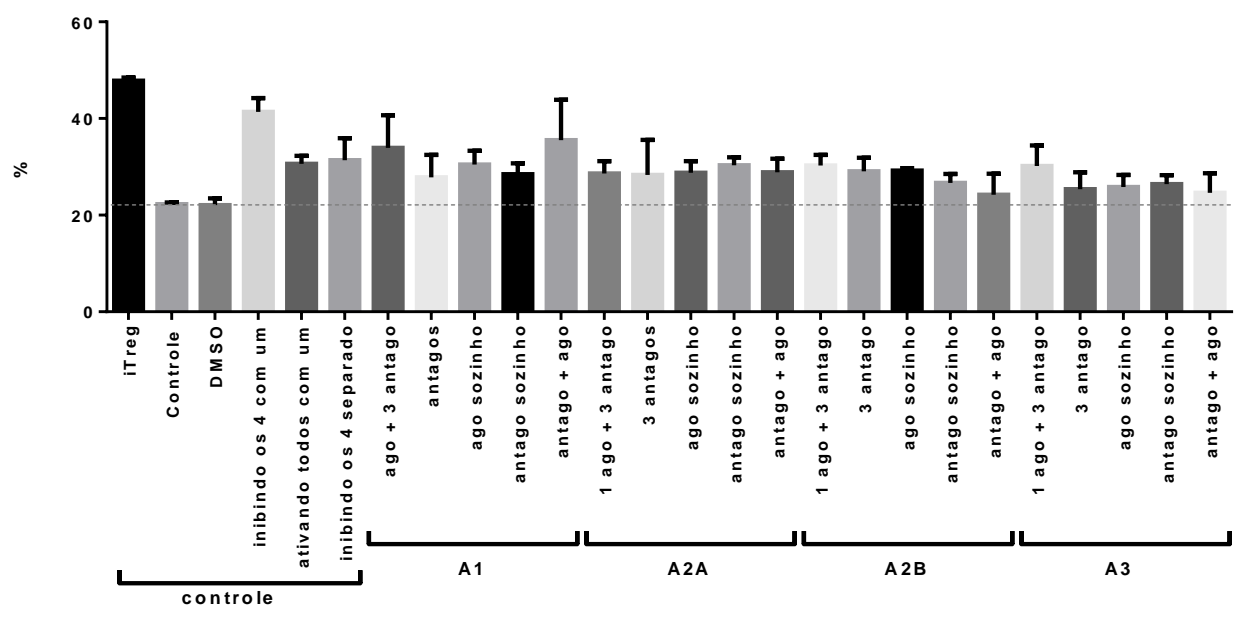

Figura a3. Sinalização de adenosina e expressão de CD39 e CD73 em linfócitos. Continuação. Análise realizada por citometria de fluxo. 


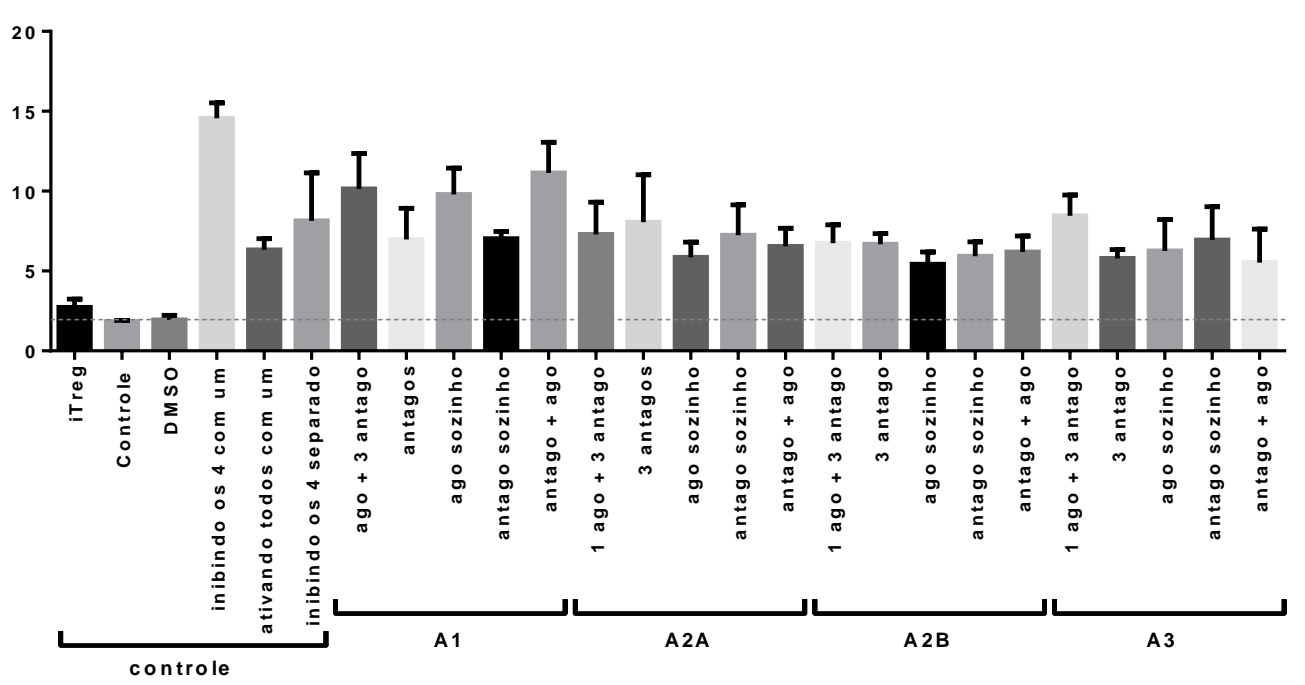

4+CD25hi CD 39+CD73+

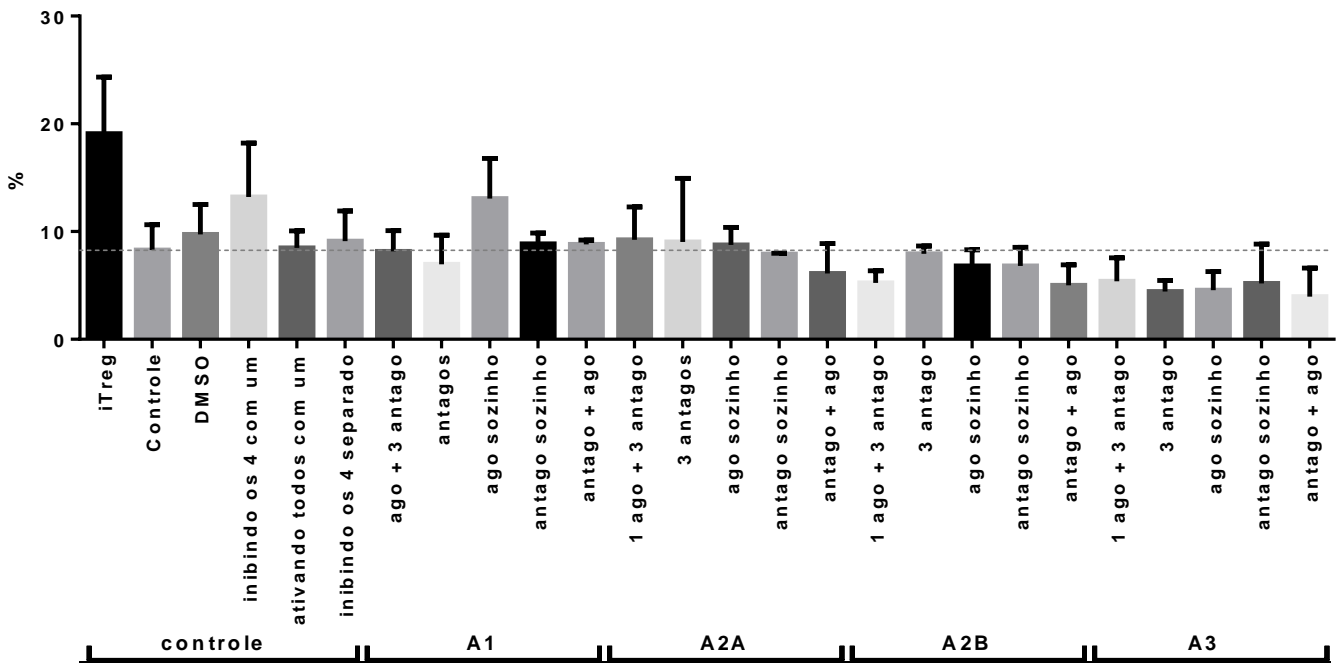

Figura a3. Sinalização de adenosina e expressão de CD39 e CD73 em linfócitos. Continuação. Análise realizada por citometria de fluxo. 
Papel dos receptores de adenosina no perfil de citocinas

IL - 2
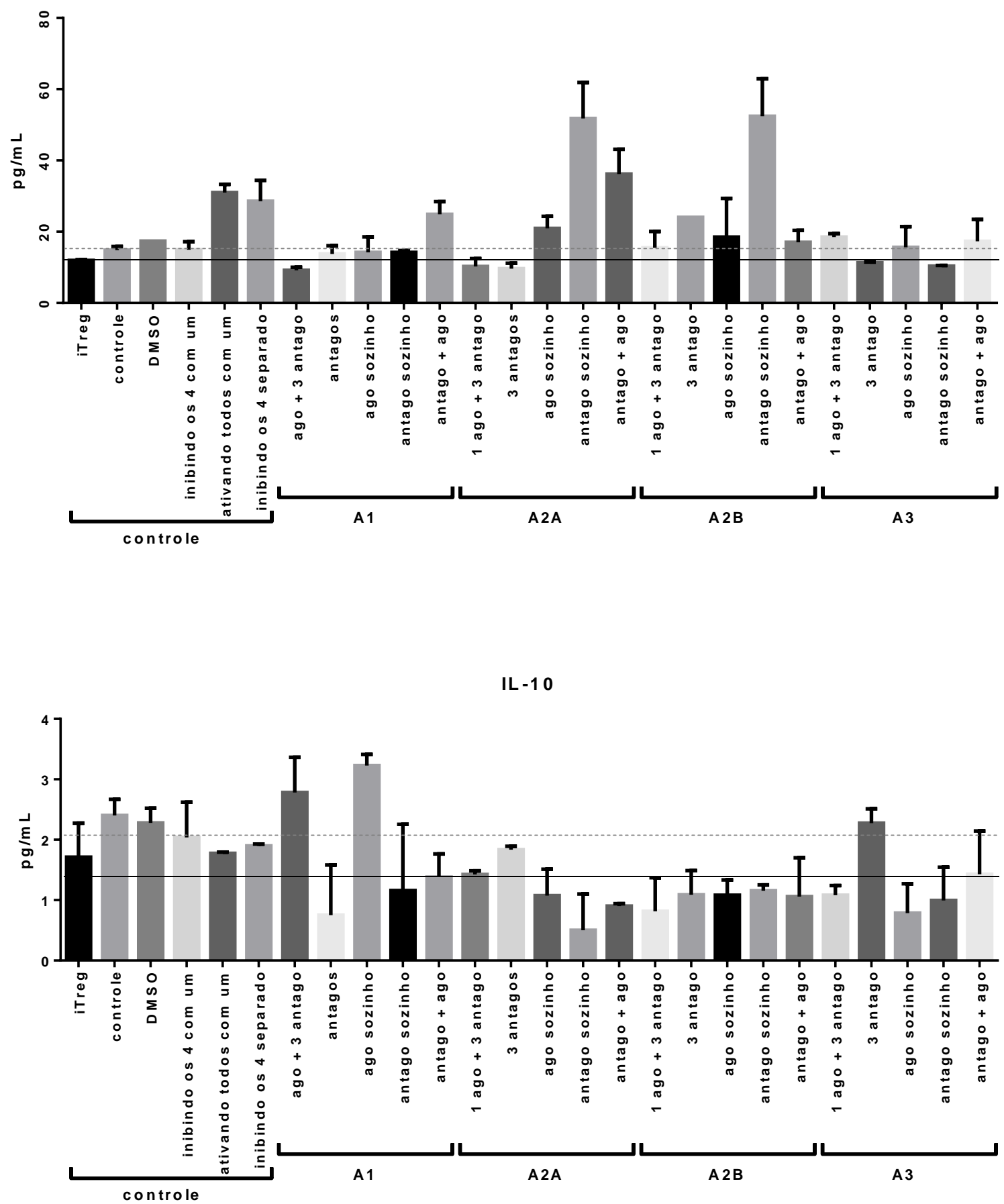

Figura a4. Quantificação de IL-2, IL-6, IL-8 e IL-10 no sobrenadante das células Tregs geradas em todos tratamentos. O sobrenadante foi coletado após o quinto dia de cultivo e os níveis das citocinas foram mensurados por CBA. Os valores acima foram expressos como média \pm SD.Oneway ANOVA, pós teste Tukey. ${ }^{*} p<0,05 ; a={ }^{*} p<0,05$ em relação ao controle. $\mathrm{N}=2$, triplicata experimental 
IL -6

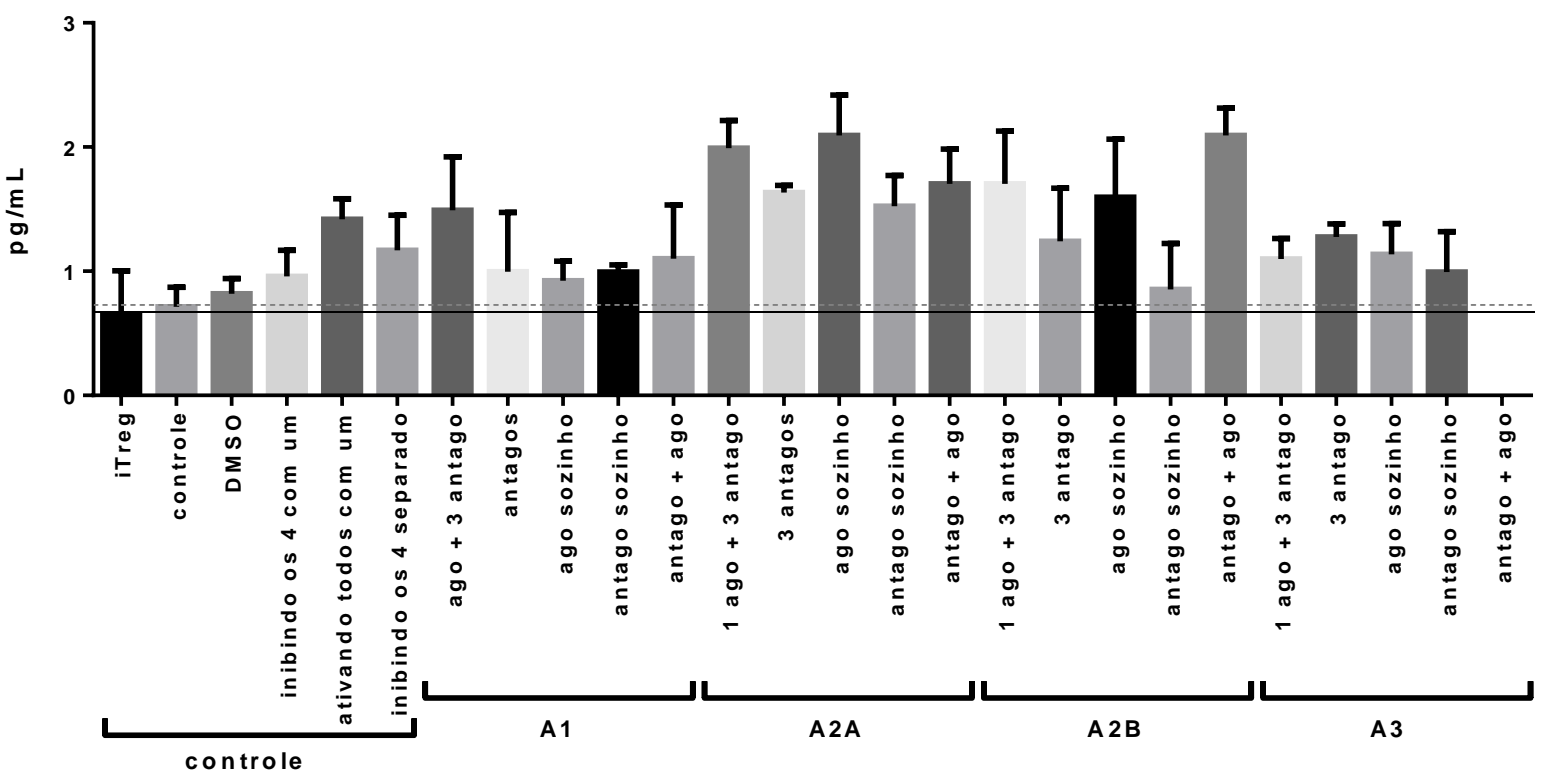

IL-8

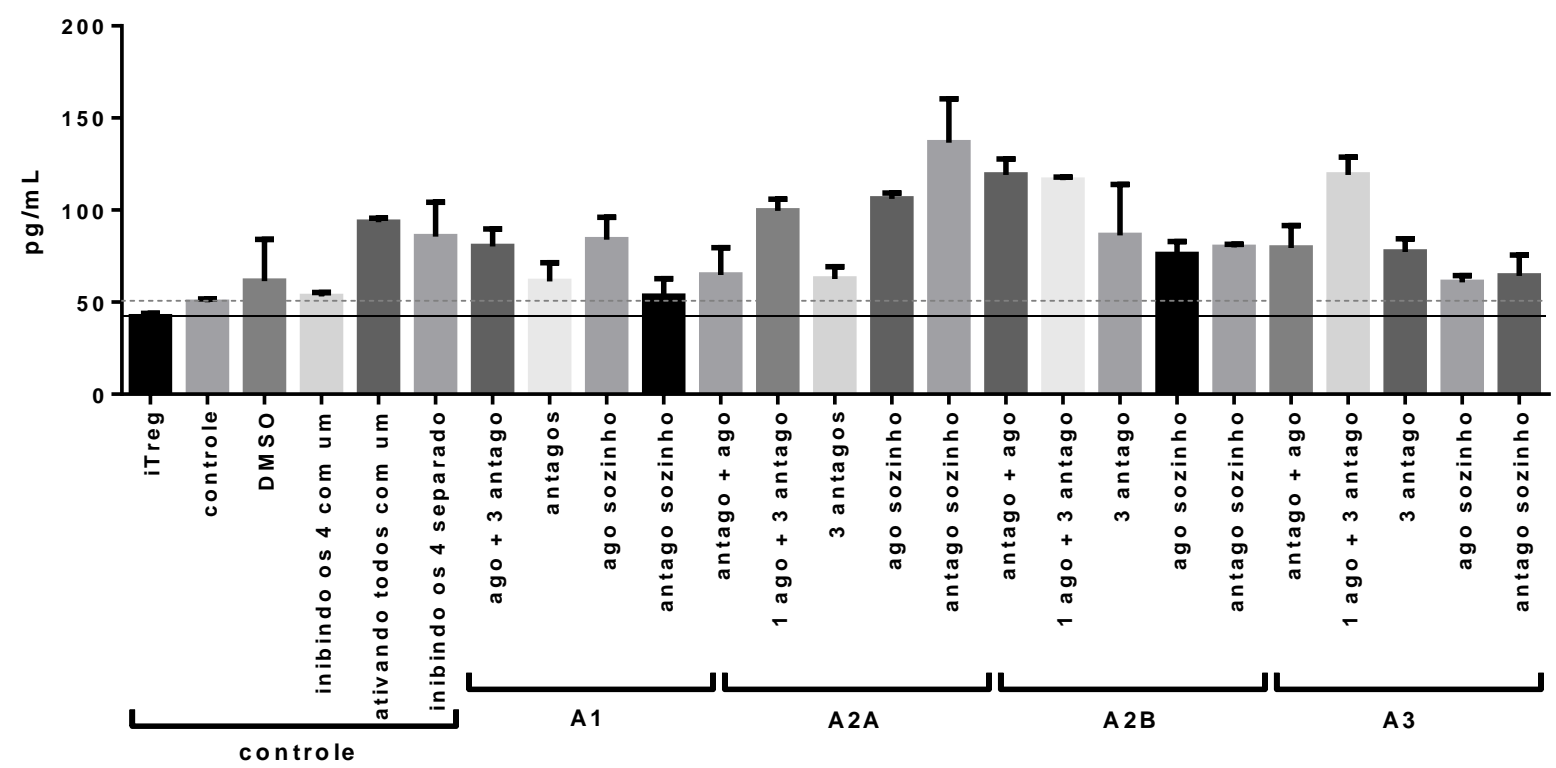

Figura a4. (continuação) Quantificação de IL-2, IL-6, IL-8 e IL-10 no sobrenadante das células Tregs geradas em todos tratamentos. $O$ sobrenadante foi coletado após o quinto dia de cultivo e os níveis das citocinas foram mensurados por CBA. Os valores acima foram expressos como média \pm SD. Oneway ANOVA, pós teste Tukey. ${ }^{*} p<0,05 ; a={ }^{*} p<0,05$ em relação ao controle. $N=2$, triplicata experimental 
Potencial supressivo dos linfócitos gerados nas diferentes condições de modulação farmacológica dos receptores de adenosina

Receptor A1

A 1

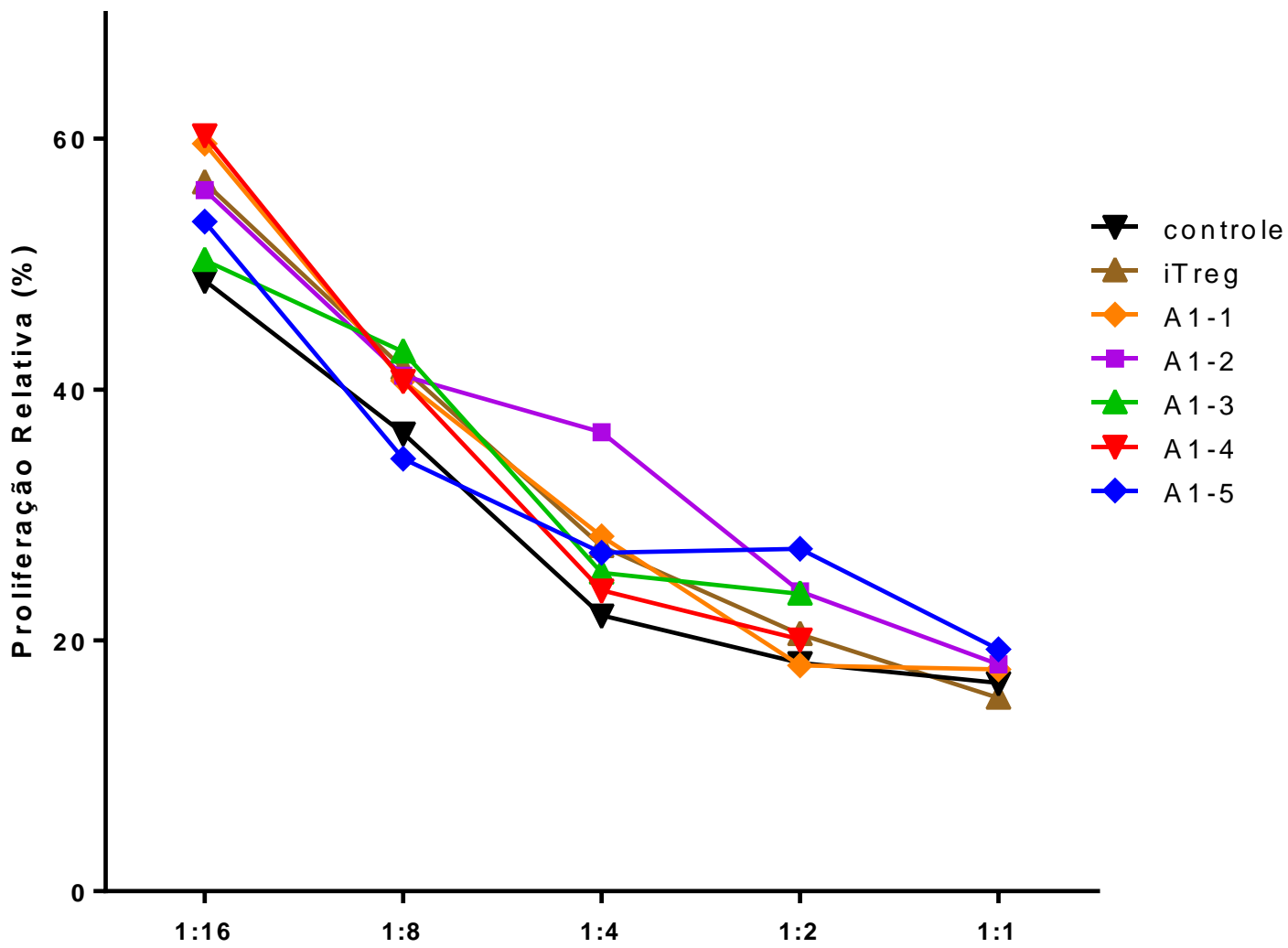

Figura a5. Avaliação da capacidade supressora das células geradas das condições que modulavam o estímulo ao receptor A1. Comparada às iTregs e a condição controle, observamos que a taxa de proliferação celular relativa a proliferação dos linfócitos T CD3+ ativados (marcados com CFSE) cultivados isoladamente. 


\section{Receptor A2a}

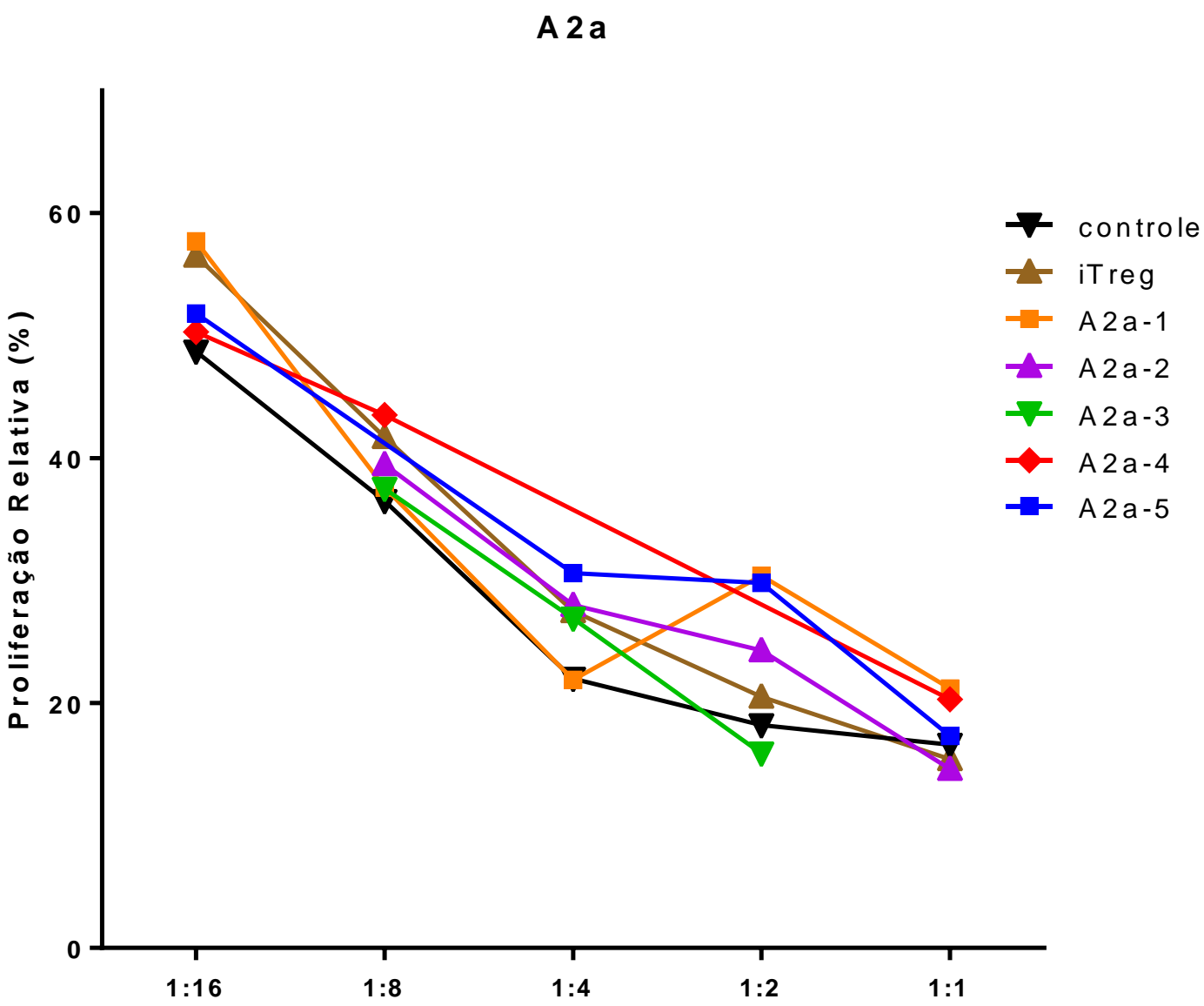

Figura a6. Avaliação da capacidade supressora das células geradas das condições que modulavam o estímulo ao receptor A2a. Comparada às iTregs e a condição controle, observamos que a taxa de proliferação celular relativa a proliferação dos linfócitos T CD3+ ativados (marcados com CFSE) cultivados isoladamente. 


\section{Receptor A2b}

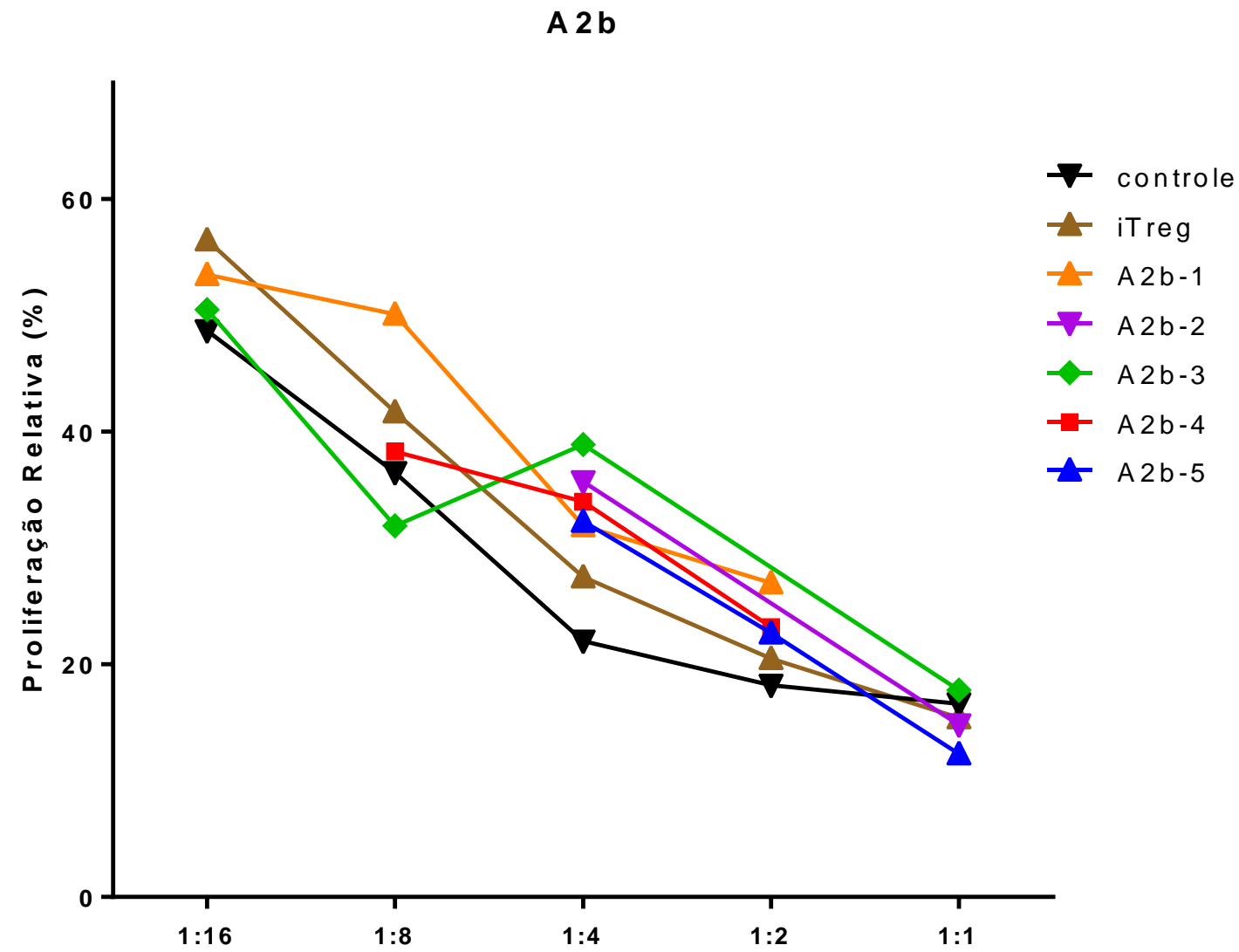

Figura a7. Avaliação da capacidade supressora das células geradas das condições que modulavam o estímulo ao receptor $\mathbf{A} \mathbf{2 b}$. Comparada às iTregs e a condição controle, observamos que a taxa de proliferação celular relativa a proliferação dos linfócitos T CD3+ ativados (marcados com CFSE) cultivados isoladamente. 


\section{Receptor A3}

A 3

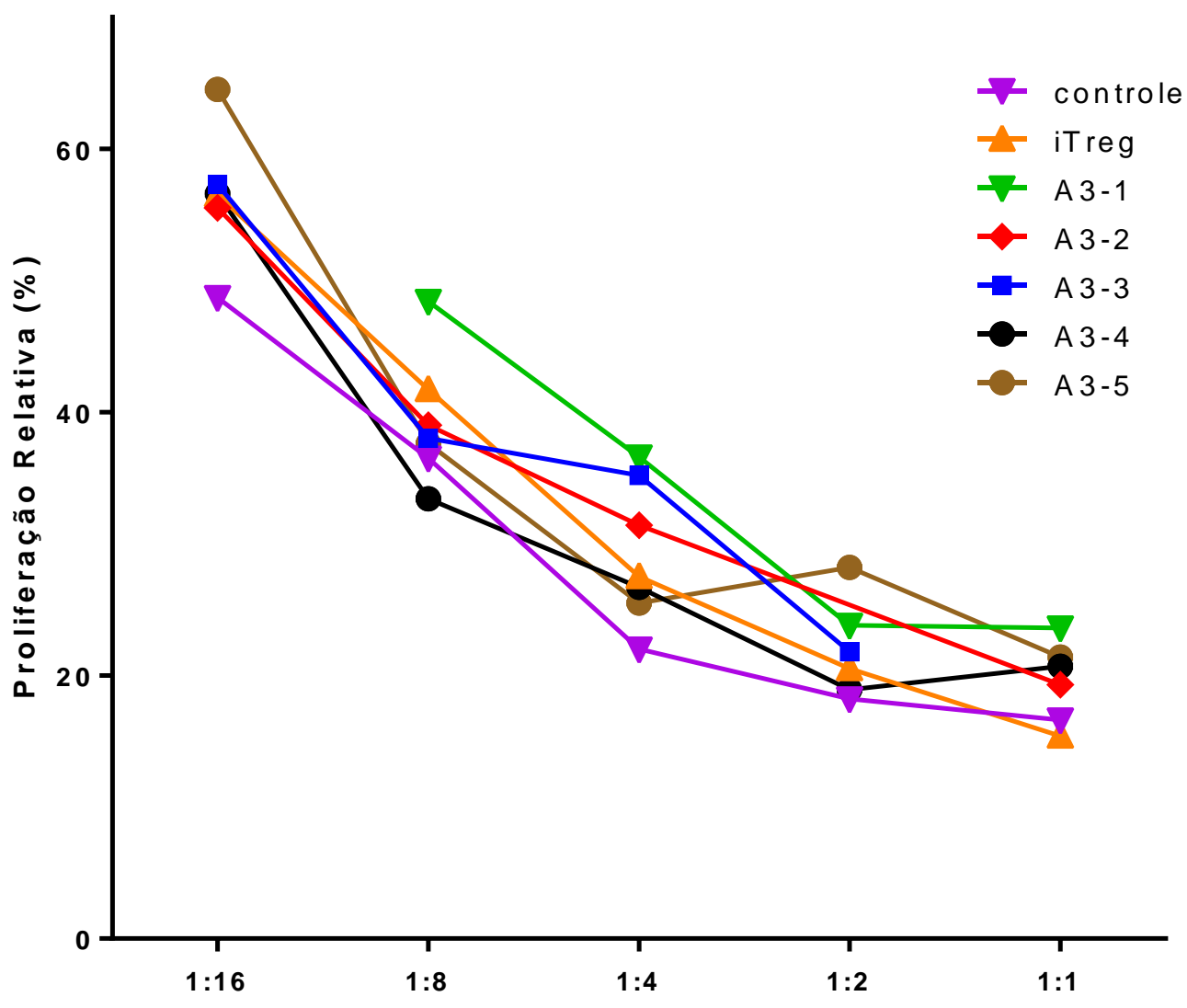

Figura a8. Avaliação da capacidade supressora das células geradas das condições que modulavam o estímulo ao receptor A3. Comparada às iTregs e a condição controle, observamos que a taxa de proliferação celular relativa a proliferação dos linfócitos T CD3+ ativados (marcados com CFSE) cultivados isoladamente. 


\section{Produção de adenosina pelos linfócitos nas diferentes condições de modulação farmacológica dos receptores de adenosina}

Ao final dos cinco dias de todos os tratamentos, o sobrenadante das culturas foi coletado para quantificação de adenosina por espectrometria de massa.

As amostras do tratamento que o EHNA não foi adicionado, figura 6, apresentaram de um modo geral valores muito abaixo daquelas tratadas com EHNA (figura 6), indicando que houve o acúmulo da adenosina ao longo dos cinco dias. Nesta condição em que não houve inibição da enzima ADA, a adenosina é constantemente degradada em inosina. $O$ tratamento com $O$ antagonista de A2a, ZM, apresentou concentrações acima do tratamento controle, condizente com o aumento da população CD39+CD73+ observado na figura 6 , porém o agonista do mesmo receptor também apresentou valores tão elevados quanto ZM. A inibição de todos os receptores com ZM a $1500 \mathrm{nM}$ resultou em níveis similares aos das drogas para $\mathrm{A2a}$, ou seja, resultados aumentados em relação ao controle. Interessantemente, foi observado que 0 tratamento com o agonista específico do receptor A1, CCPA, também induziu maior acúmulo de adenosina ao final dos cinco dias.

Em nossos resultados, observamos que em todas as condições associadas ao EHNA, os valores quantificados de adenosina partiram de $200 \mathrm{pg} / \mathrm{mL}$ e chegaram a valores médios de $1000 \mathrm{pg} / \mathrm{mL}$, no tratamento de inibição total com ZM a $1500 \mathrm{nM}$. Neste experimento, destacamos a condição tratada com IB, agonista de A3, tanto de forma isolada como as que IB estão associadas a outras drogas que apresentou níveis maiores que o controle com EHNA. 


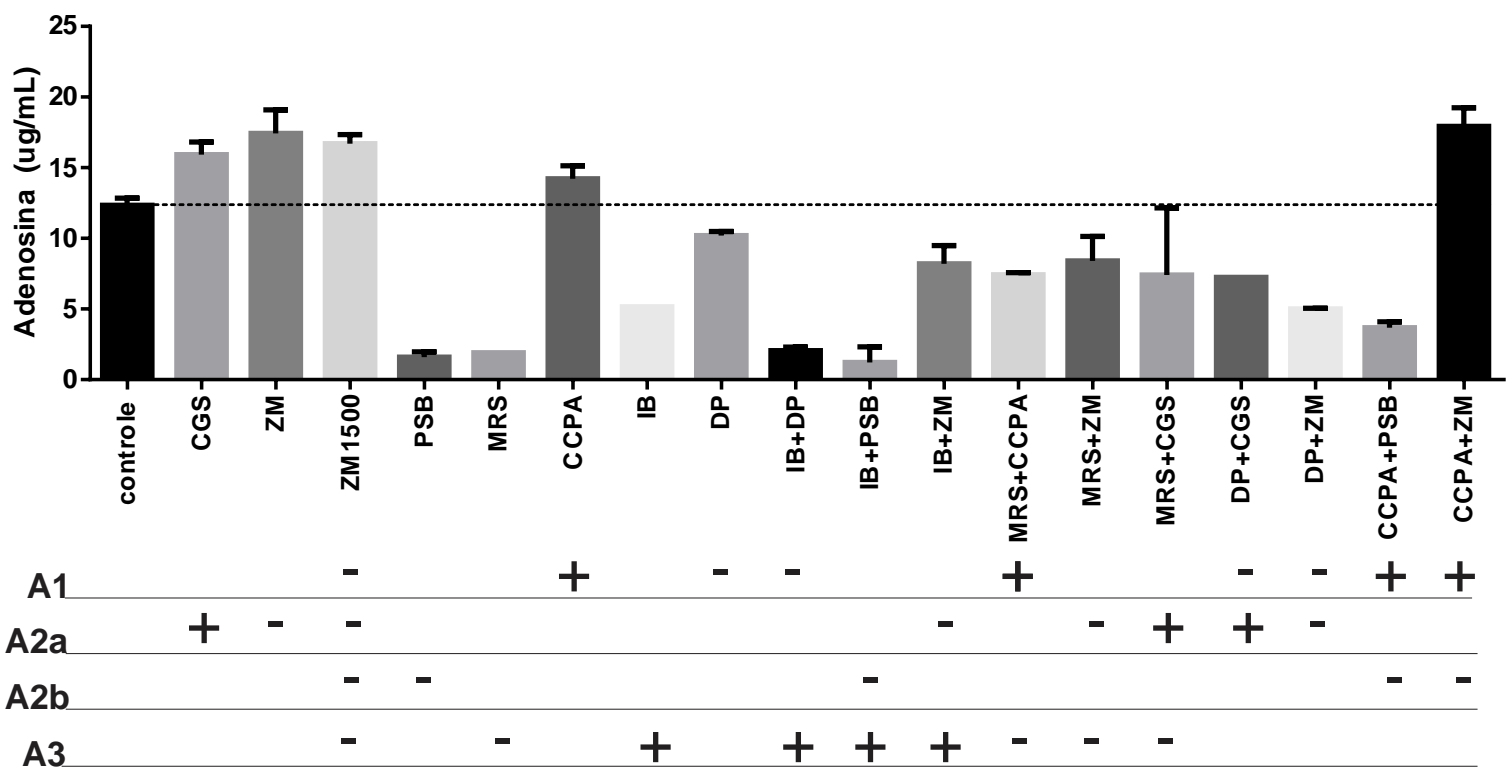

Figura a9. Níveis absolutos de adenosina presente em sobrenadante de cultura. (picogramas $/ \mathrm{mL}$ ) Análise da concentração de adenosina ao final dos cinco dias de cultura e da combinação dos tratamentos com as drogas específicas para cada receptor de adenosina por espectrometria de massas. Triplicata experimental $(\mathrm{N}=1)$.

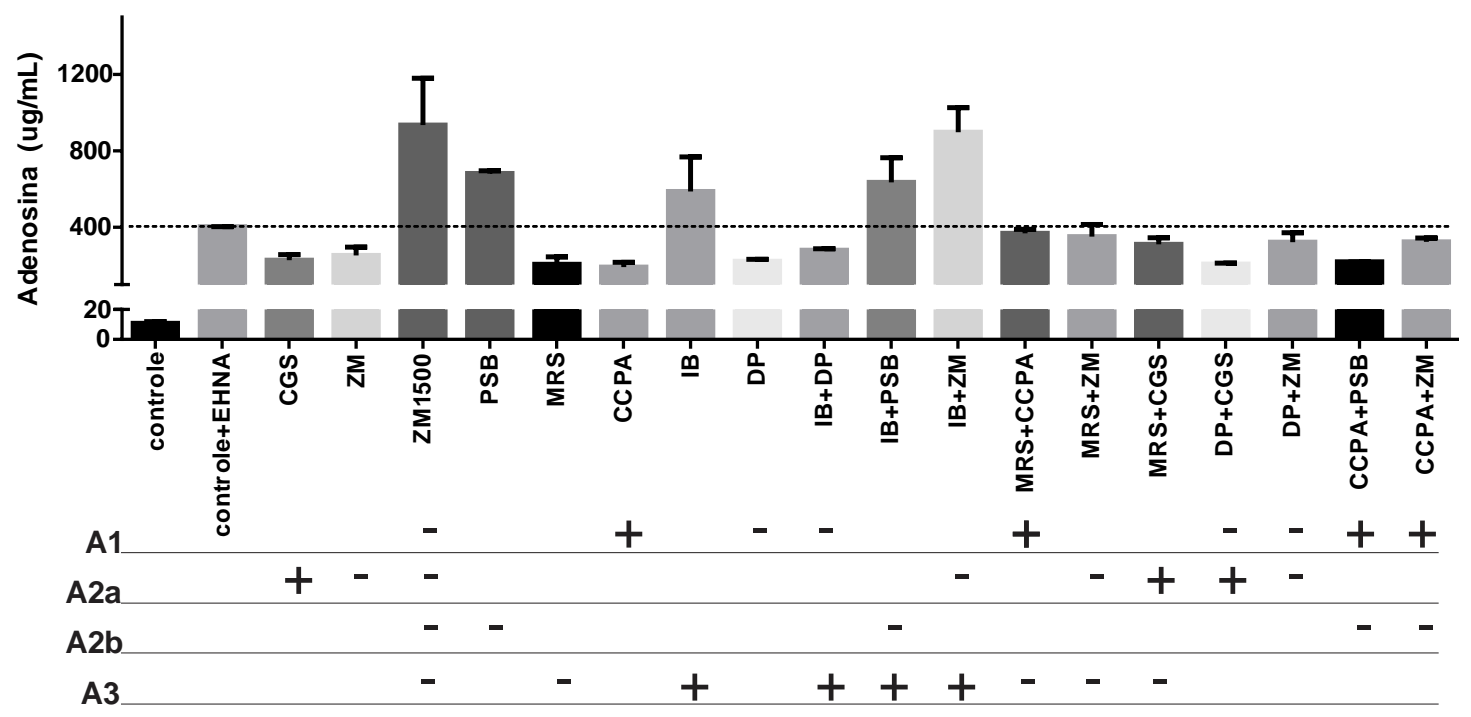

Figura a10. Adenosina em sobrenadante de cultura com EHNA (inibidor de ADA). picogramas $/ \mathrm{mL}$ Análise da concentração de adenosina dos meios de cultura de tratamento das T naive com a combinação dos tratamentos com as drogas específicas para cada receptor de adenosina com adição de EHNA. O sobrenadante foi coletado após 5 dias de cultura e a adenosina foi quantificada por meio da espectrometria de massa. Triplicata experimental $(\mathrm{N}=1)$. 


\section{Apêndices Capítulo II}

\section{Efeito da modulação farmacológica dos receptores de adenosina na expressão gênica de ADA, CD39, CD73 e receptores de adenosina em CTMs}

Um trabalho de KERKELA (2016) sugere que a produção de adenosina em MSCs requer cooperação com CD39 expresso por células T. Segundo ele, não há expressão membranar em MSCs de CD39, entretanto, SALDANHAARAUJO et al. (2011) já havia relatado o aumento da expressão de CD39 em MSCs em seu trabalho demonstrando co-cultivo de MSCs com CD3+ ativadas. Curiosamente, Kerkela especula que em determinadas situações o CD39 intracelullar poderia ser transportado para superfície celular. Investigamos se haveria tal exposição do receptor CD39 em três principais condições: a) manipulação dos receptores de adenosina, b) estímulo com citocinas inflamatórias e c) estímulo com sobrenadante rico/pobre em microvesículas de células CD3+ ativadas.

Para isto, células MSCs foram obtidas a partir do banco de células do Hemocentro de Ribeirão Preto, e foram inicialmente isoladas de pacientes saudáveis e posteriormente caracterizadas (marcação positiva para os marcadores CD13, CD29, CD49E, CD73, CD90, CD105 e CD146 e negativa para CD14, CD31, CD34, CD45 e HLA-DR) conforme descrito em trabalhos anteriores do grupo (SALDANHA-ARAUJO et al., 2011; SANGIORGl et al., 2016). As MSCs foram cultivadas em meio alphaMEM suplementado com $15 \%$ de soro fetal bovino em presença de $100 \mathrm{U}$ de penicilina/estreptomicina a $5 \% \mathrm{CO} 2$ e $37^{\circ} \mathrm{C}$. As garrafas com $90 \%$ de confluência foram dissociadas utilizando uma solução de tripsina a $0,1 \%$ em PBS por 3 minutos e depois neutralizadas com o próprio meio de cultura, posteriormente criopreservadas com a finalidade de criar um estoque para o posterior uso, ou utilizadas em procedimentos experimentais. Em geral, para os procedimentos experimentais, as células foram utilizadas na quinta passagem.

Em seguida, observamos a expressão gênica das ectonucleotidases CD39/CD73 nas MSCs (Figura 10). Para isto, foram plaqueadas $10^{4} \mathrm{MSC}$ em placas de 24 poços e foi aguardado um período de $24 \mathrm{~h}$ para estas aderirem e 
estabilizarem. Em seguida, as células foram mantidas por mais $72 \mathrm{~h}$, na ausência ou na presença de agonistas ou antagonistas de receptores de adenosina nas respectivas concentrações: NECA a 300nM (agonista dos 4 receptores), CGS a 30nM (agonista de A2a), ZM a 25nM (antagonista de A2a), $\mathrm{ZM}^{*}$ a 1500nM (antagonista dos 4 receptores), PSB a 10nM (antagonista de A2b), IB-Meca a 4nM (agonista de A3) e adenosina a 100nM (agonista de A1).
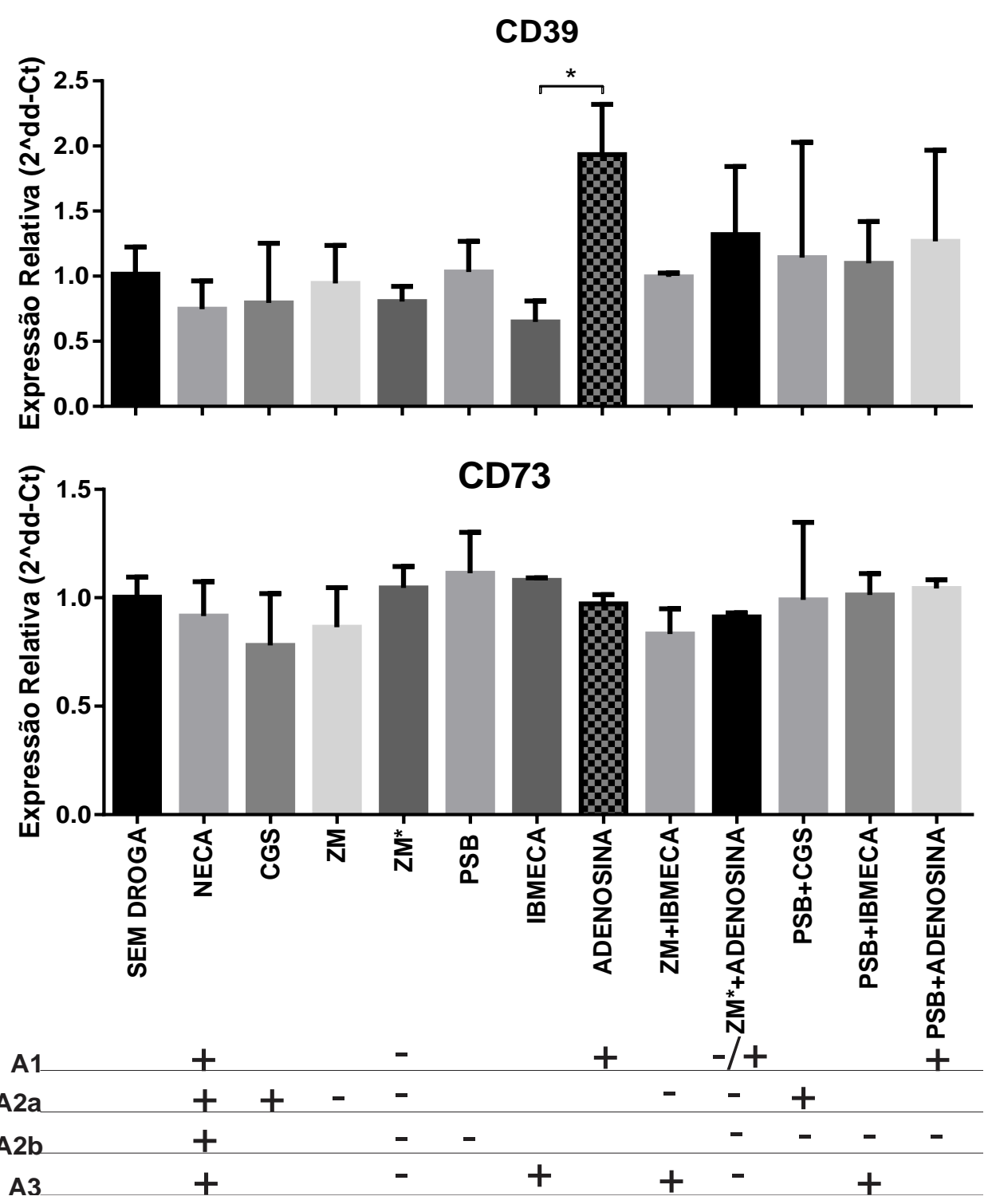

Figura 8. Expressão relativa de CD39 e CD73 em CTMs. Gráfico representativo dos valores de expressão relativa dos marcadores CD39 e CD73 em CTM cultivadas por 3 dias na presença ou ausência da combinação de drogas. Os valores de deltaCt foram normalizados com base na expressão do gene endógeno GAPDH, e a amostra sem tratamento (sem droga) foi utilizada como amostra referência. Triplicata experimental ( $\mathrm{N}=1$, um doador). 
Conforme o demonstrado na Figura 10, é possível notar que há um significativo aumento na expressão de CD39 quando o receptor A1 é estimulado com adenosina, porém quando há combinação com inibidores dos receptores $\mathrm{A} 2 \mathrm{~b}$ (PSB) e $\mathrm{A} 2 \mathrm{a}$ (ZM) os valores reduzem e se tornam comparáveis aos do controle sem droga. Não foi observada diferença na expressão de CD73, quando comparada ao grupo controle por nenhuma combinação de droga.

\section{Efeito da modulação farmacológica dos receptores de adenosina na expressão proteica e localização celular de CD39 e CD73 em CTMs}

Posteriormente, observamos por citometria de fluxo a presença de CD39/CD73 intracelular e na superfície das células CTM. Para tanto, ao final das $72 \mathrm{~h}$ de tratamento, as células foram dissociadas utilizando uma solução de tripsina a $0,1 \%$ em PBS por 3 minutos e depois neutralizadas com o próprio meio de cultura, posteriormente as marcações de superfície foram realizadas incubando as células com os anticorpos CD39 e CD73 (BD-Biosciences) e com os controles de isotipo adequados. Após incubação com os anticorpos pertinentes (em geladeira por $20 \mathrm{~min}$ ), os tubos foram centrifugados por $5 \mathrm{~min}$ a 2000 RPM, o sobrenadante descartado, e as células ressuspendidas em 200uL de PBS formol (1\%). A marcação predominante na superfície das CTMs é de CD73, porém há em torno de 10\% de marcação com CD39 (Figura 11 superior direita). As marcações intracelulares foram realizadas também após a dissociação com tripsina e neutralização com meio de cultura com soro. As células foram inicialmente fixadas com solução de PBS formol $2 \%$ por 20 minutos a $4^{\circ} \mathrm{C}$ e em seguida foram ressuspensas em $500 \mathrm{uL}$ de solução de permeabilização (FACS permeabilizing solution, BD, San Diego, CA, USA) e incubadas por 10 minutos a TA. Após a lavagem com PBS foram adicionados os anticorpos CD39 APC e CD73 PE que foram incubados por $30 \mathrm{~min}$ em TA. Foram novamente centrifugados por $5 \mathrm{~min}$ a 1500 RPM, o sobrenadante descartado, e o pellet de células ressuspendido em 500 ul de PBS formol (1\%) para aquisição das células pelo citômetro (FACScalibur, Becton Dickinson). Em células permeabilizadas, observou-se prevalente marcação duplo positiva para 
CD39 e CD73 (cerca de 67\%) do que quando comparado à sua expressão na superfície celular.

\section{CD39 e CD73 em superfície:}
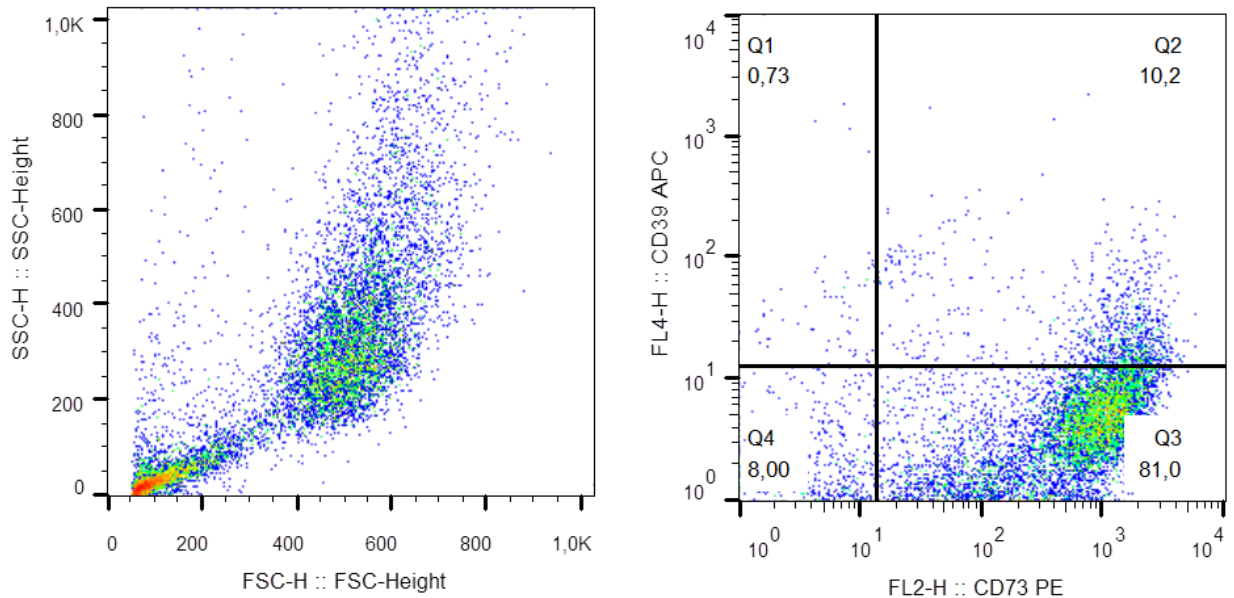

\section{CD39 e CD73 intracelular:}
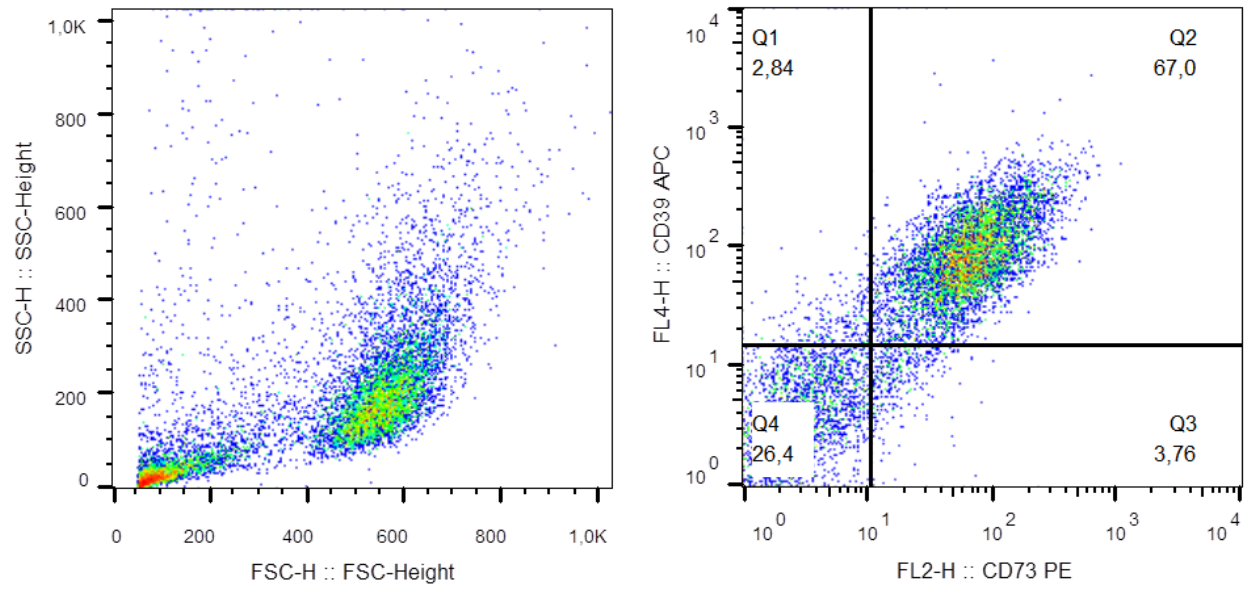

Figura a9. Análise por citometria dos marcadores CD39 e CD73 em CTMs. Dot plot representativo de tamanho por complexidade interna (esquerda) e de CD39 por CD73 (direita). Painel superior, marcação de superfície das CTMs, com predominante marcação de CD73. Painel inferior, marcação das CTMs permeabilizadas, com predominante dupla marcação de CD39 e CD73.

Relativamente aos marcadores durante a manipulação dos receptores de adenosina (Figura 12), observamos em um ensaio inicial que houve pouca ou nenhuma variação na porcentagem dos marcadores em superfície. Destacase a mudança na intensidade de fluorescencencia (MFI) do marcador CD73 
(Figura 12 centro), observada nos tratamentos com adenosina (MFI=650) muito similar controle, porém foi drasticamente reduzida para $\mathrm{MFI}=350$ quando associada à $\mathrm{ZM}^{*}$ (inibidor de todos ADORAs); este resultado foi igualmente observado na população duplo positiva. 
CD39 E CD73 EM SUPERFÍCIE:

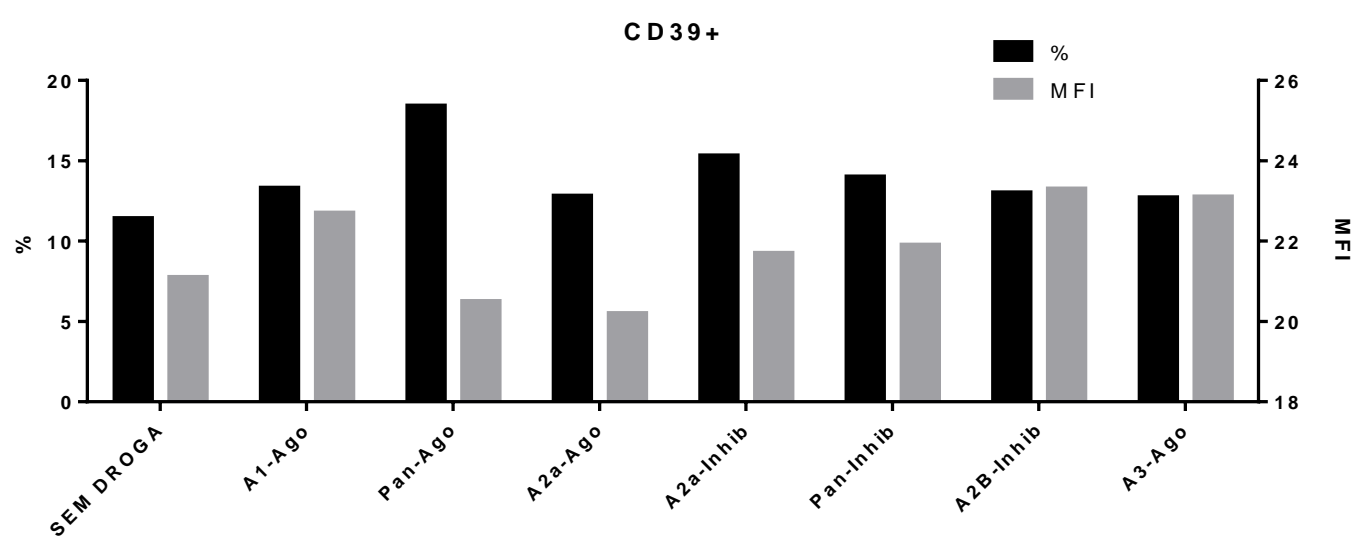

$\mathrm{CD}^{2}+$
$\mathrm{MFI}$

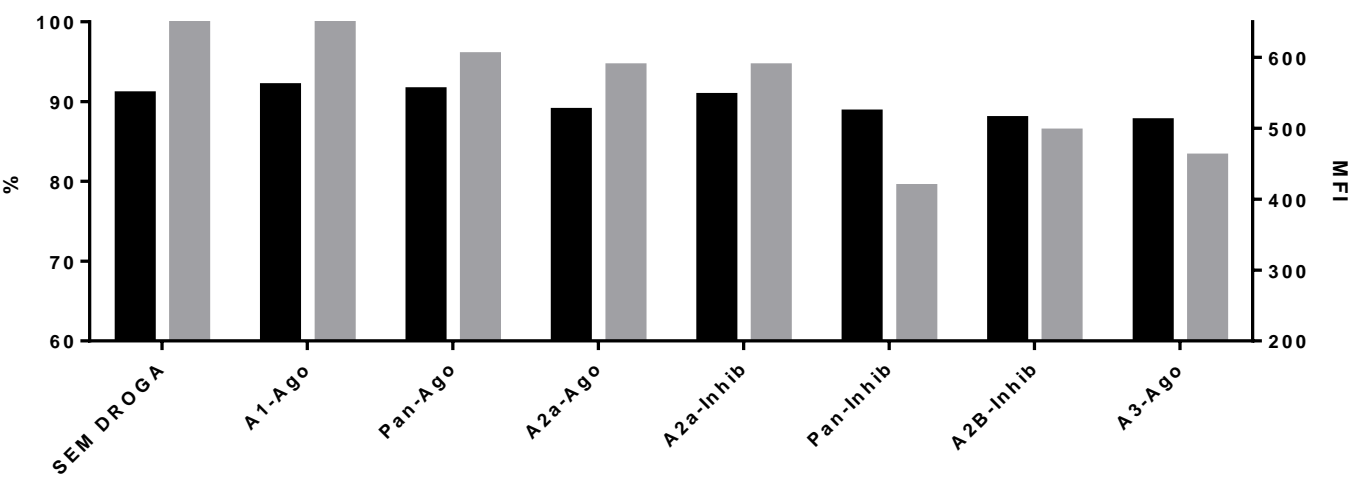

CD39+ CD73+

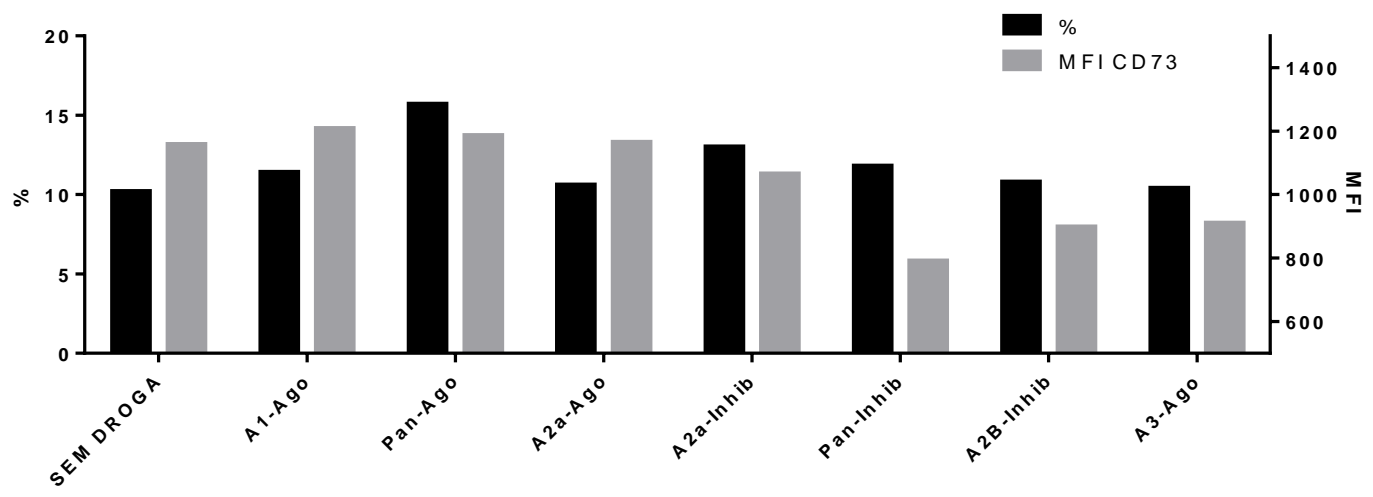

Figura 10. Expressão de CD39 e CD73 na superfície de CTMs. Os gráficos representam o percentual de expressão dos marcadores (\%) assim com a Intensidade Média de Fluorescência (MFI) nas CTMs na presença ou na ausência das drogas. 
Diferentemente da baixa marcação (aproximadamente 10\%) para CD39 observada em superfície, em células permeabilizadas a porcentagem média de todos os tratamentos foi de $70 \%$, apenas o tratamento com inibição dos quatro receptores juntamente com estímulo de $\mathrm{A} 1\left(\mathrm{ZM}^{*}+\right.$ adenosina) apresentou redução para $57 \%$, porém quando observados isoladamente nenhum efeito pode ser notado. Em relação a população duplo positiva novamente foram observadas diferenças relativas ao $\mathrm{MFI}$ de cada marcador isoladamente (Figura 13 inferior). A inibição de A2a com ZM a 25nM induziu significativa queda no MFI de CD39 (60) em relação ao controle (100), enquanto a inibição total com ZM a 1500nM levou a um aumento para MFI de CD39=130. 


\section{CD39 E CD73 INTRACELULAR}
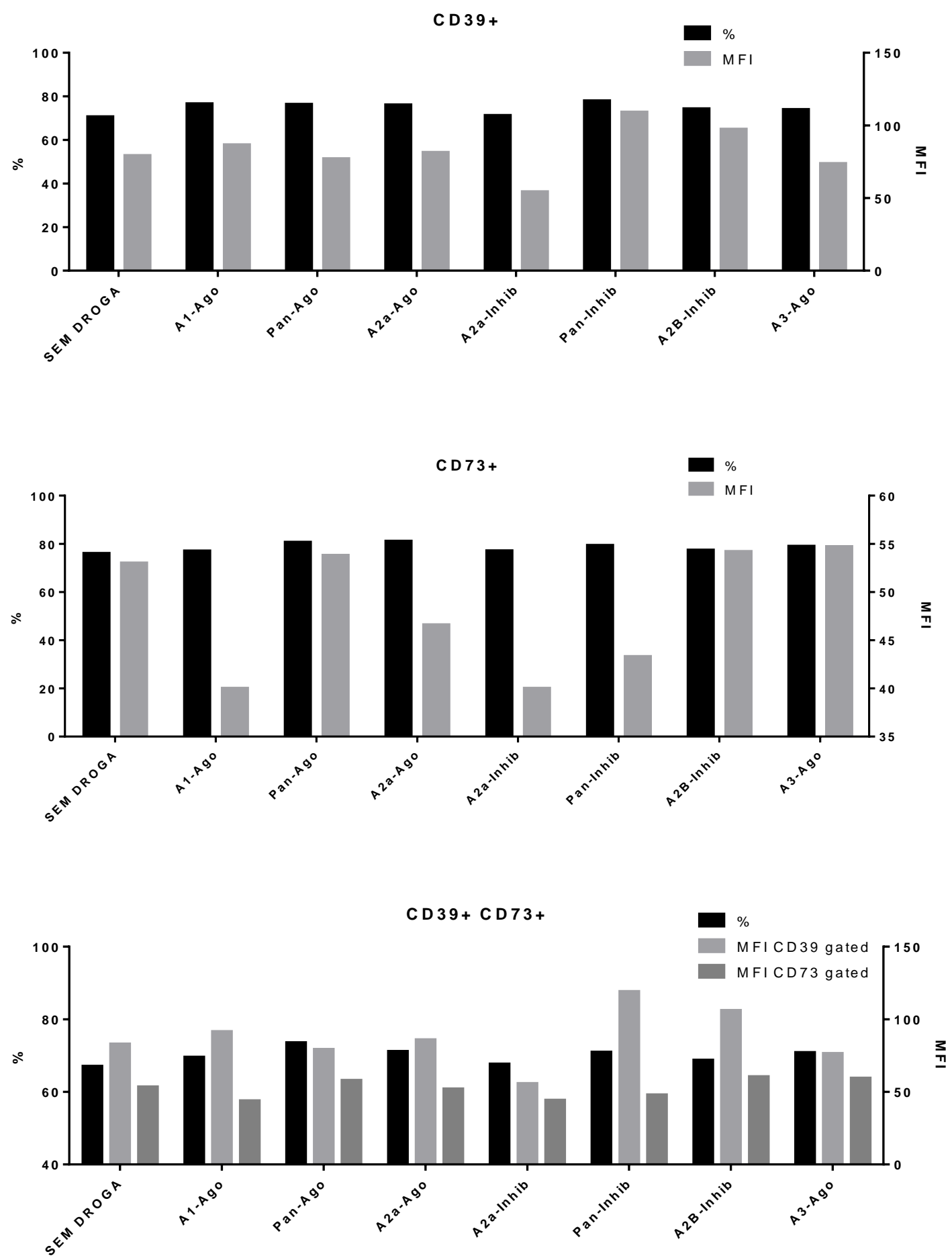

Figura a14. Expressão intracelular de CD39 e CD73 em CTMs. Os gráficos representam o percentual de expressão dos marcadores (\%) assim com a Intensidade média de Fluorescência (MFI) nas CTMs na presença ou na ausência das drogas. 
17- Anexos 


\section{Aprovação do orçamento pela UPC.}

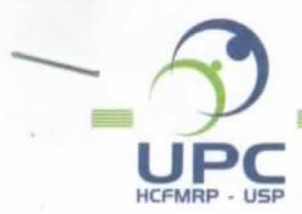

HOSPITAL DAS CLINICAS DA FACULDADE DE MEDICINA DE RIBEIRĀO PRETO DA UNIVERSIDADE DE SÁO PAULO

www.hcrp.fmrp.usp.br

PROJETO DE PESQUISA

Ribeirão Preto, 12 de feveruio 2014 .

Ilustríssima Senhora

Sistema UPC n 7526

Dr. ${ }^{a}$ Marcia Guimarães Villanova

MD. Coordenadora do Comitê de Ética em Pesquisa

Do HCFMRP-USP e da FMRP-USP

Senhora Coordenadora,

Encaminho em anexo o projeto de pesquisa intitulado

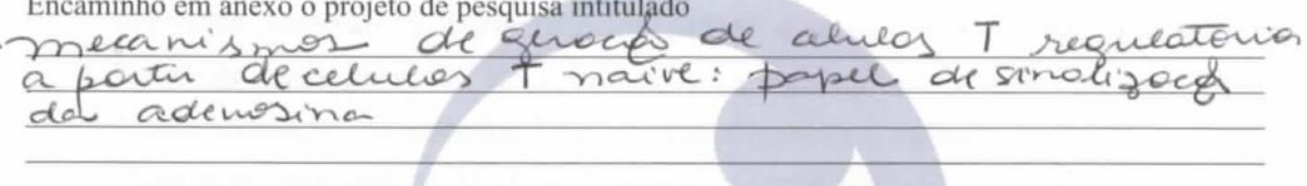

juntamente com a documentação necessária para avaliação ética deste Comitê.

O projeto acima mencionado será desenvolvido no (a) clímica mécica

Informo também que o pesquisador responsável e o orientador possuem currículo Lattes.

$\mathrm{O}$ orçamento do presente projeto foi analisado pela equipe técnica da UPC antes da submissão ao

Comitê e foi aprovodo

Equipe Técnica UPC

Atenciosamente,
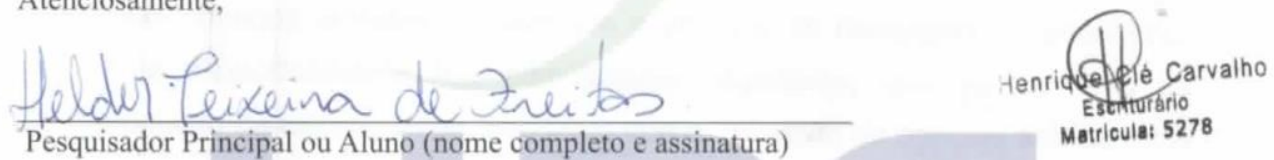

Pesquisador Principal ou Aluno (nome completo e assinatura)

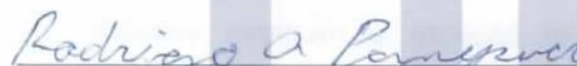

Pesquisador Principal ou Orientador (nome completo e assinatura)

De acordo:

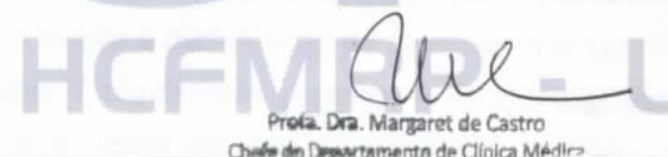

Chefe de Departamento (assinatura e carimbo)
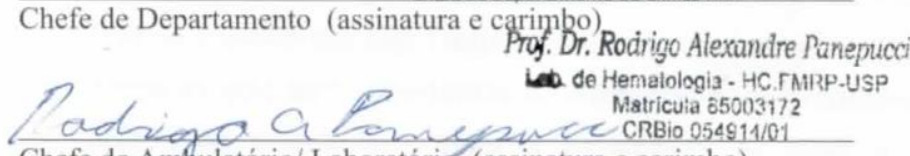

Chefe do Ambulatório/ Laboratório (assinatura e carimbo)

Obs.: Caso algum chefe possua vinculo com a pesquisa, deverá ser solicitada assinatura do suplente.

Após assinatura em todos os campos, digitalizar toda a documentação do check list e encaminhar ao CEP via Plataforma Brasil.

HC - Campus Universitário

Monte Alegre 14048-900 Ribeiräo Preto SP

UNIDADE DE PESQUISA CLINICA

Fone: (16) 3602-2632 FAX: 3602-2962 


\section{Termo de Consentimento Livre e Esclarecido.}

\section{HOSPITAL DAS CLÍNICAS DA FACULDADE DE MEDICINA DE RIBEIRÃO PRETO DA UNIVERSIDADE DE SÃO PAULO}

Termo de consentimento livre e esclarecido

Você está sendo convidado(a) para participar desta pesquisa. A participaçăo é voluntária. Após ser esclarecido(a) sobre as informações contidas neste documento, no caso de aceitar fazer parte do estudo, assine ao final deste documento, que está em duas vias. Uma delas é sua e a outra é do pesquisador responsável.

Nome da Pesquisa: "Mecanismos de geração de células T regulatórias a partir de células T naive: papel da sinalização da adenosina"

Pesquisadores Responsáveis: Prof. Dr. Rodrigo Alexandre Panepucci e doutorando Helder Teixeira de Freitas

\section{Descriçăo da Pesquisa:}

Durante o parto normal, após o nascimento da criança, a placenta é expulsa pelo útero da mãe. Esta placenta juntamente com o cordão umbilical é descartada depois do parto. O sangue que fica preso na placenta e no cordão umbilical após o nascimento do bebê, contém um grupo de células do sangue chamadas células T naive (ou células T virgem), que são descartadas junto.

As células T virgem são capazes de se tornar em outro tipo de célula no nosso organismo, chamada célula $T$ regulatória. As células $T$ virgem também podem se tornar células $T$ regulatórias em experimentos realizados em laboratório de pesquisa. Essa transformaçăo é interessante, pois as células T regulatórias poderão ser utilizadas no tratamento de muitas doenças, como a esclerose múltipla, a artrite reumatoide e o lúpus, diminuindo os danos causados por essas doenças.

Portanto, o objetivo desta pesquisa é estudar como as células T virgem se tornam células $T$ regulatórias, e assim auxiliar no entendimento e desenvolvimento de novos tratamentos que poderão utilizar as células $T$ regulatórias.

Caso a mãe concorde em colaborar com esta pesquisa, a placenta e o cordăo umbilical, ao invés de serem descartados, terão seu sangue coletado. Este sangue será enviado ao Laboratório de Hematologia do HCIFMRP (que estuda o sangue). Esse laboratório vai tentar transformar as células T virgem Versăo 3 Data da última modificação 26/11/2014 


\section{Termo de Consentimento Livre e Esclarecido.}

em células $T$ regulatórias, e estudar como ocorre essa transformação. Esse sangue será utilizado somente para esta pesquisa e no caso de sobrar sangue, este será descartado.

Nenhum procedimento adicional que possa incomodar a mãe ou o bebê será realizado. Mesmo que a mãe não concorde em participar da pesquisa, o parto será realizado da mesma forma. Esta pesquisa não trará nenhum risco ou benefício à mãe ou ao bebê, considerando que o sangue do cordão e placenta será coletado após a sua retirada não influenciando no tempo do parto, nem mesmo no seu atendimento neste hospital. No entanto, segundo a Resolução do CNS 466/12 "toda pesquisa que envolve seres humanos apresenta riscos, mesmo que mínimos". Considerando isto, nesta pesquisa um dos riscos aplicáveis é a possível quebra de sigilo ou confidencialidade dos dados. A mãe não terá nenhuma despesa proveniente da participação nesta pesquisa, por isso não haverá ressarcimento monetário. Importante lembrar que o sujeito de pesquisa tem direito a indenizações conforme as leis vigentes no país, caso ocorra algum dano decorrente de sua participação na pesquisa.

Caso o paciente não concorde em participar desta pesquisa, isto não irá alterar de forma alguma o seu atendimento neste Hospital.

Assim, se desejar participar desta pesquisa, lhe asseguramos:

a) A garantia de receber a resposta a qualquer pergunta ou esclarecimento de qualquer dúvida a respeito dos procedimentos, riscos, benefícios e de outras situações relacionadas com a pesquisa que participarei;

b) A liberdade de retirar o meu consentimento e deixar de participar do estudo, a qualquer momento, sem que isso traga prejuízo à continuidade do meu tratamento;

c) A segurança de que não serei identificado e que será mantido o caráter confidencial da informação relacionada à minha privacidade;

d) O compromisso de que me será prestada informação atualizada durante o estudo, ainda que esta possa afetar a minha vontade de continuar dele participando;

e) O compromisso de que serei devidamente acompanhado e assistido durante todo o período de minha participação no projeto, bem como de que

Versão 3

Data da última modificação 26/11/2014 


\section{Termo de Consentimento Livre e Esclarecido.}

será garantida a continuidade do meu tratamento, após a conclusão dos trabalhos de pesquisa.

Pesquisador: Data: / / Helder Teixeira de Freitas

Fui devidamente esclarecido e declaro que concordo inteiramente com as condições que me foram apresentadas e que livremente manifesto a minha vontade em participar do referido projeto.

Nome por extenso (Responsável):

Assinatura (Responsável):

Ribeirão Preto, de de 20

Qualquer dúvida sobre esta pesquisa, entrar em contato pelo telefone: (16) 3602-2223 Helder Teixeira de Freitas ou Dr. Rodrigo Alexandre Panepucci. Laboratório de Hematologia/Biologia Molecular, Hospital das Clínicas, FMRPUSP

Qualquer dúvida ética, entrar em contato com o Comitê de Ética em Pesquisa do Hospital das Clínicas e da Faculdade de Medicina de Ribeirão Preto (16) 3602-2228; 


\section{Aprovação no comitê de ética da Mater.}

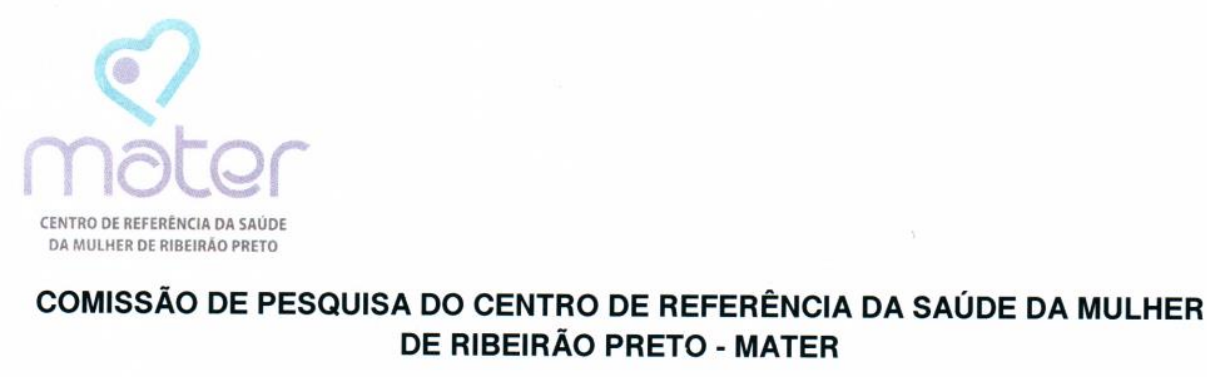

Ref.: Projeto de Pesquisa: Mecanismos de geração de células $\mathrm{T}$ regulatórias a partir de células T naive: papel da sinalização da adenosina.

№ $006 / 2014$

Helder Teixeira de Freitas

Prezado Pesquisador (a)

Informamos que o seu projeto foi avaliado pela Comissão de Pesquisa Clinica do CRSM-Mater no dia 09/05/2014 e considerado aprovado para realização nessa instituição.

Lembramos que essa aprovação pressupõe o cumprimento das seguintes necessidades:

1- Apresentação do parecer do CEP antes do início da abordagem de potenciais sujeitos para o estudo

2- Apresentação de relatórios parciais (Anexo 3), semestralmente, indicando o andamento da pesquisa.

3- Apresentação de relatório final de pesquisa (Anexo 3) que deverá ser acompanhado de um resumo estruturado da mesma (uma lauda, contendo introdução, métodos, resultados e conclusões) para a documentação do projeto de pesquisa junto ao CRSM-Mater

4- Todos os procedimentos relacionados ao projeto de pesquisa que não estejam dentro da rotina do serviço deverão ser realizados pela equipe do projeto, não se utilizando de funcionários da instituição.

Atenciosamente,

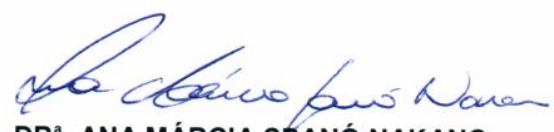

DR ${ }^{a}$. ANA MÁRCIA SPANÓ NAKANO

Presidente da Comissão de Pesquisa do Centro de Referência da Saúde da Mulher

Av. Wanderley Taffo, no 330 - Quintino Facci II - CEP 14070-250 - Ribeirão Preto - SP Fone: (16) 3962-8200 - Fax: (16) 3962-8213 


\section{Aprovação no comitê de ética da FUNDHERP.}

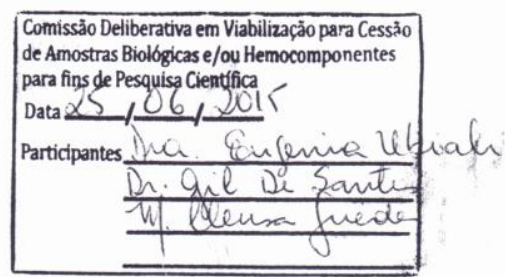

Em análise à solicitação em anverso, esta Comissão decidiu pela sua aprovação, com a seguinte ressalva:

1. A enfermeira Maria Fernanda Capelli não pode aplicar o TCLE para pesquisa, sendo esta atribuição de competência de um dos pesquisadores, como, aliás, determina o CEP.

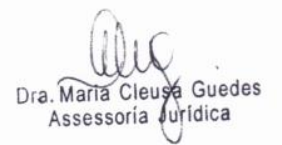

Assessoria Juridica

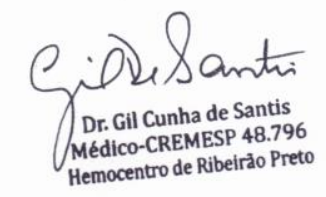

Ciencua as aluno a a Sua. Maristela Delopocto

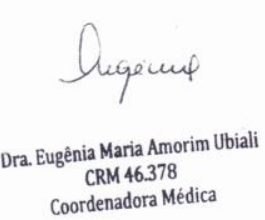

(4).378 